\title{
Sorcery and Morality in the Andes: Illness, Healing, and Brujería in Kañaris (Lambayeque, Peru)
}

by

\author{
Marieka Sax
}

A thesis submitted to the Faculty of Graduate and Postdoctoral Affairs in partial fulfillment of the requirements for the degree of

Doctor of Philosophy

in

Anthropology

Carleton University

Ottawa, Ontario

(C) 2014

Marieka Sax 


\begin{abstract}
Sorcery (brujería, curanderismo) is a genre of both ritual healing and malicious witchcraft practiced throughout northern Peru. In the Andean community of Kañaris, practitioners call upon the power of place-based spirits called "enchantments" (encantos) to both cause and cure certain classes of illness. These individualized spirits are embodied in particular mountains, waterfalls, and high-altitude lakes. They are repositories for a sacred power that has the potential to both help and harm people, as manifested in a person's body, productive activities, and social relations. Yet in Kañaris, the encantos do not usually address lay people directly or cause illness by their own will. Instead, ritual specialists called "sorcerers" (brujos) or "masters" (maestros) direct the power of the encantos towards a person with the intention to benefit or injure them. Therefore, moral responsibility for illness attributed to sorcery lies with the sorcerer, and the client on whose behalf he acts. People in Kañaris say that malicious witchcraft is always motivated by envy, and perpetrated by a fellow community member. The people who should be most trustworthy are also the most likely to do withcraft.

In Kañaris, sorcery is tied to not just illness and healing, but a wider sense of well-being articulated alongside luck and production, its inverse in personal envy and social conflict, and the local moral economy. Sorcery matters to people in Kañaris for three main reasons. First, through diagnosing and healing illness, it provides them with an account for and response to their suffering. Second, by raising a person's luck, it enables people to improve their productive capacities and mitigate their vulnerability to future suffering. Third, by attributing responsibility for their suffering, it tells people something about their relations to fellow community members. Ultimately, sorcery points to the hope people have of making sense of their suffering, coming to terms with the evils people do to one another, and applying this understanding to their own lives in order to live and work alongside one another again. In this sense, sorcery facilitates the reintegration of the afflicted individual back into the whole of society.
\end{abstract}




\section{Acknowledgements}

I am indebted to many people. First and foremost I thank the people of Kañaris for permitting me to visit their community over eighteen months in 2011-12. I am especially grateful to "Mercedes," "Andrés," "Isabel," and other individuals who welcomed me into their homes, provided me food and lodging, invited me to participate in household and community events, allowed me to accompany them during their daily tasks, taught me about things that matter to them, and took me to visit people in surrounding communities. I am a better person for knowing each of you.

I also thank Peter Gose for his many years of supervision and mentorship. I owe much of my scholarly success to his gentle guidance and enduring support. I also thank him for inspiring me to venture deeper into the field of anthropology in a university class over a decade ago. I hope I make you proud. Any outstanding deficiencies are of course my own.

I could not have carried out the years of study, fieldwork, and writing without the support of my colleagues and friends, Leanne Davis, Cheryl Matthew, and Daniel Tubb.

Sometimes the only thing that kept me going was knowing I was not the only one going through this.

I am also grateful for the assistance and encouragement provided by Kristin Bright, Bernhard Leistle, Jen Pylypa, Daniel Rosenblatt, and Frances Slaney. You are all exemplary role models for me, and I welcome any chance to work together again in the future.

The Department of Sociology and Anthropology at Carleton University provided me with everything I needed - and much I did not know I would need - to complete my doctoral studies. I thank everyone who participates in this intellectually stimulating community.

Several individuals in Peru also helped me along the way. I am grateful to Juan Javier Rivera Andía for introducing me to Kañaris in the first place, and for extending invitations to participate in academic conferences and publish papers. I also thank Luis Millones at the Universidad Nacional Mayor de San Marcos, Juan Castañeda Murga at the Universidad Nacional de Trujillo, Gisela Cánepa Koch and Marco Curatola Petrocchi at the Universidad Pontificia Católica del Perú, and Alicia Galdos Béjar at Centro Tinku in Cuzco.

I am eternally grateful for my family and their many kinds of love and support. I made it to the end because of you. In particular, my parents David and Karen Sax never tired of discussing the details of my research, which was crucial in the final months of writing. Here's to many more years and adventures together. 
This research was carried out with funding provided by the Social Sciences and Humanities Research Council of Canada (Joseph-Armand Bombardier CGS Doctoral Scholarship 2010-13; Michael Smith Foreign Study Supplement 2012), the Ontario government (Ontario Graduate Scholarship 2013-14), and Carleton University (2009-14).

Earlier drafts of what largely became Chapters 6 and 7 were presented at the European Association of Social Anthropologists Annual General Meeting (Nanterre University, Paris, 2012); the "Anthropology and Otherness" workshop organized by Bernhard Leistle at Carleton University (2013); and the "Amerindian Rites and Non-Human Entities in South America" workshop organized by Juan Javier Rivera Andía at the Netherlands Institute of Advanced Study in the Humanities and Social Sciences (Wassenaar, The Netherlands, 2013). Revised versions of the papers presented in Ottawa and The Netherlands are forthcoming.

All translations from Spanish are my own. Unless otherwise noted, all names are pseudonyms. Where appropriate, personal details have been modified to protect the identities of individuals. 


\section{A note on orthography}

Throughout this dissertation, I attempt to follow, to the best of my abilities, the orthography for the Quechua of Ferreñafe as set out in Gerald Taylor's seminal work (1982, 1996; but see also Quesada Castillo 1976). This dialect differs in significant ways from the more common Peruvian Quechua of Cuzco and Ayacucho. The Quechua of Ferreñafe refers to the dialect spoken in the districts of Kañaris and Incahuasi, along with certain geographically contiguous areas in the regions of Lambayeque, Piura, and Cajamarca (Taylor 1996: 5). For our purposes, the relevant things to know are:

- /i/ and /e/ are very similar and may be interchanged by speakers

- $/ \mathrm{o} /$ and $/ \mathrm{u} /$ are very similar and may be interchanged by speakers

- $/ \tilde{n} /$ is pronounced like /ny/ in "canyon"; it is the same as the Spanish / $\tilde{n} /$

- /11/ is pronounced like/ge/ in "garage" (or like/zh/ in "Zhivago"); it is not pronounced like the Spanish /11/ (which is similar to the English /y/)

- $/ \hat{\mathbf{c}} /$ is pronounced like $/ \mathrm{ch} /$ while holding the tip of the tongue at the back of the top of the mouth (it sounds similar to /tr/ in "try," but at the back of the mouth rather than behind the teeth)

- /q/ takes on different sounds depending on its placement in the word:

○ at the beginning of the word, /q/ is generally pronounced like /h/ in "hope" (similar to the Spanish $/ \mathrm{j} /$ )

- at the end of the word, /q/ is generally pronounced like / $/$ in "look"

$\circ$ in other situations (such as the beginning of the last syllable), /q/ is either like $/ \mathrm{g} /$ or $/ \mathrm{k} /$ but with the top of the tongue further in the back of the mouth, so that it sounds like something in between /ng/ in "sing" and /kh/ in "khaki" (it varies from one speaker to another)

I use this orthography for Quechua terms specific to Kañaris (Ackkay, mallqey, etc.). In the case of words common throughout the Andean cultural area (ayllu, Inca, Tahuantinsuyu, etc.), spelling follows academic convention, and not the orthography specific to the Quechua of Ferreñafe. 


\section{Table of Contents}

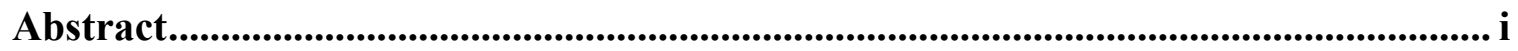

Acknowledgements .............................................................................................. ii

A note on orthography ...................................................................................................... iv

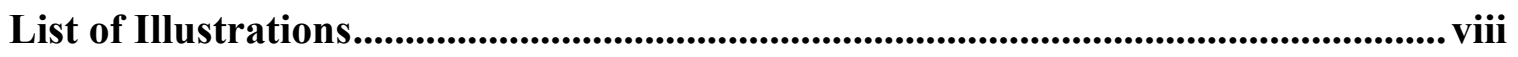

Figure 1: Map of Peru ............................................................................................. ix

Figure 2: Map of the Region of Lambayeque.................................................................... $x$

Figure 3: Map of the District of Kañaris ...................................................................... xi

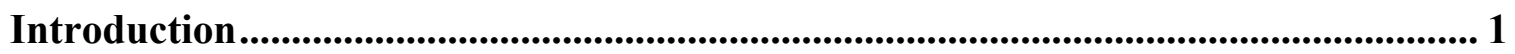

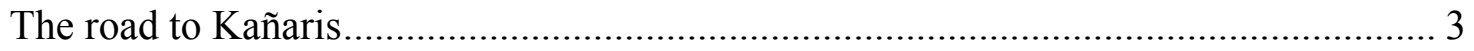

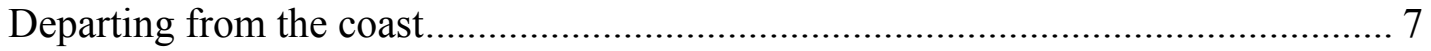

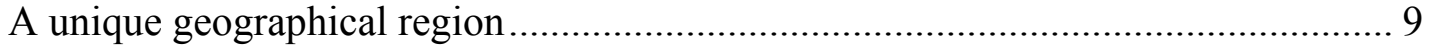

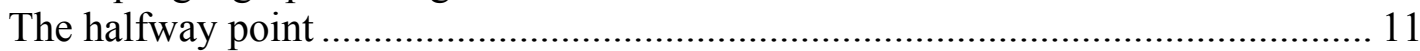

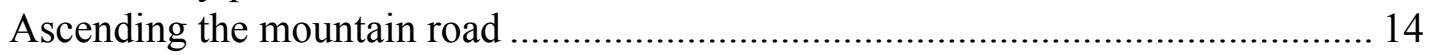

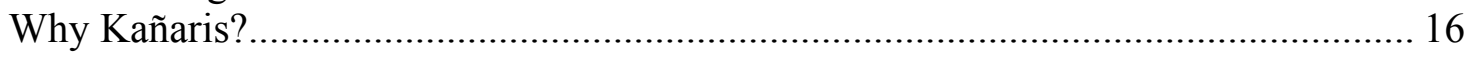

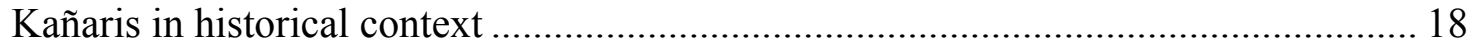

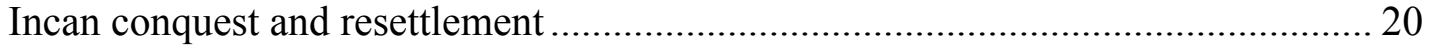

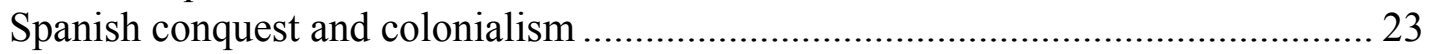

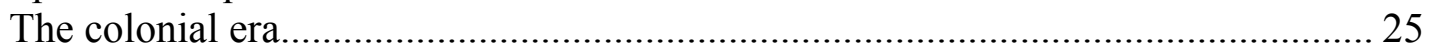

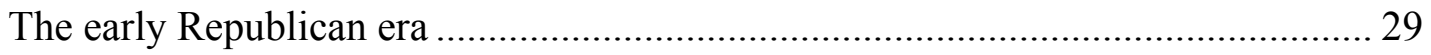

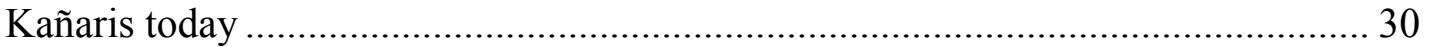

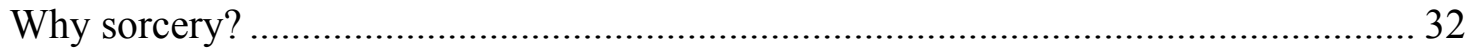

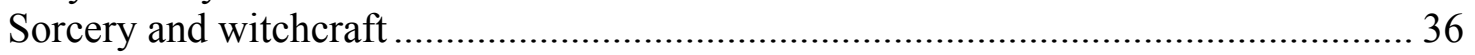

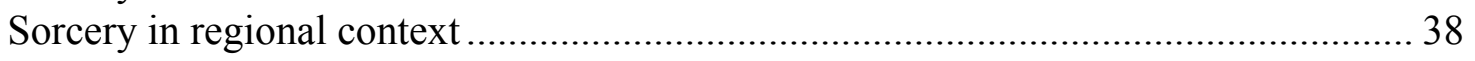

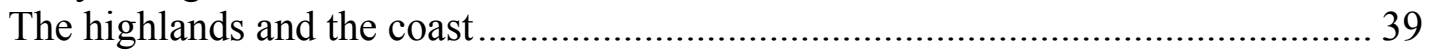

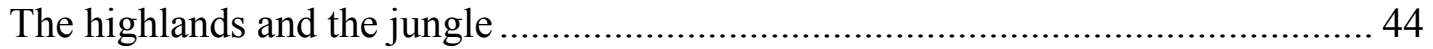

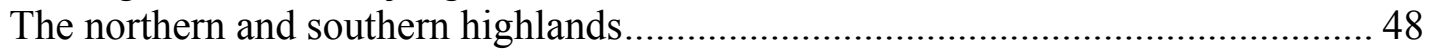

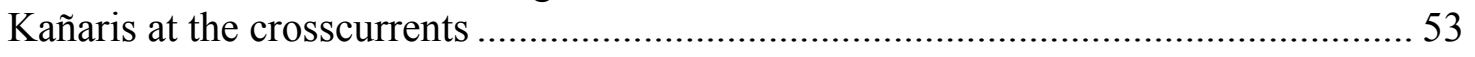

Chapter 1: The Community of Kañaris..................................................................... 57

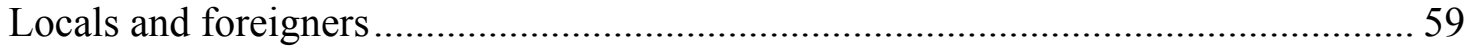

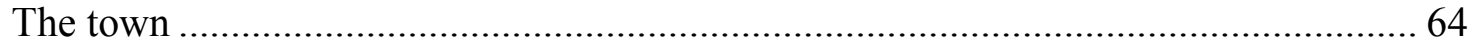

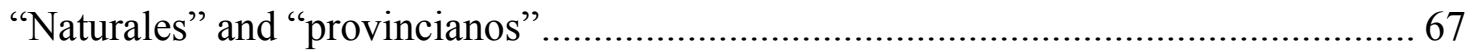

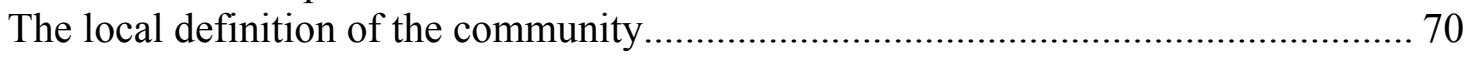

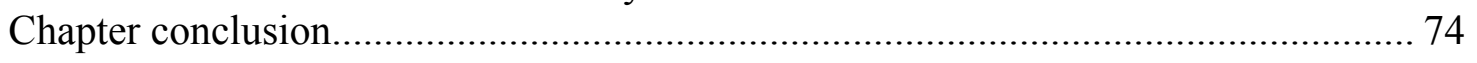

Chapter 2: Local Politics ................................................................................................. 77

The municipality, the community council, and the underlying dilemma .................... 81

"The provincianos are a wedge in community solidarity"......................................... 84 


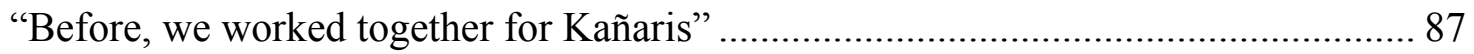

Gaps in the idealized narrative.......................................................................... 92

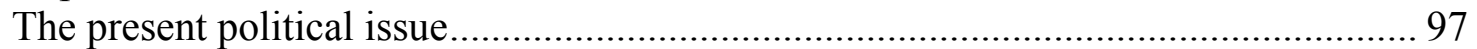

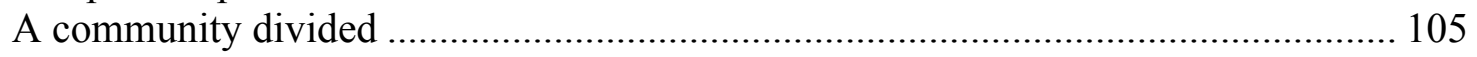

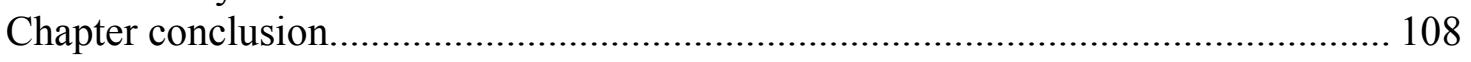

Chapter 3: Family and Household ..................................................................... 111

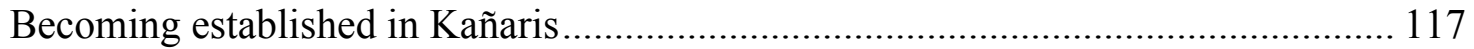

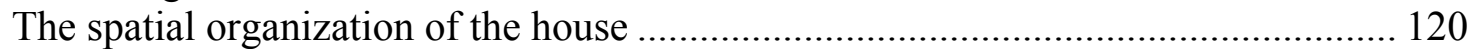

The household as the basic social and economic unit........................................... 125

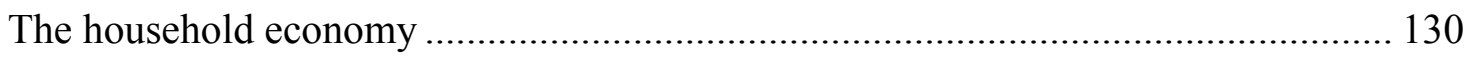

The agricultural year ...................................................................................... 134

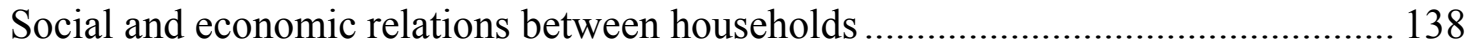

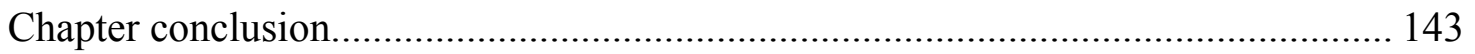

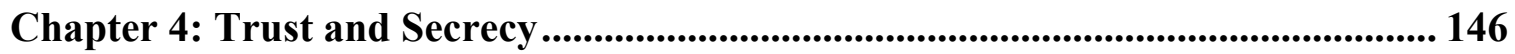

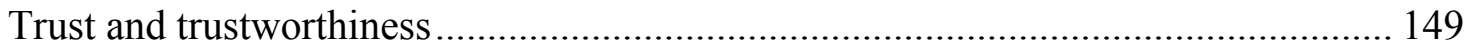

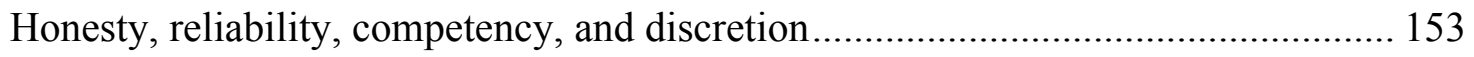

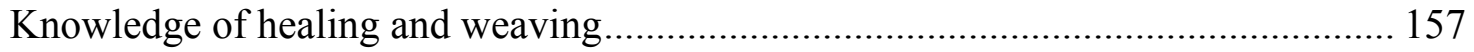

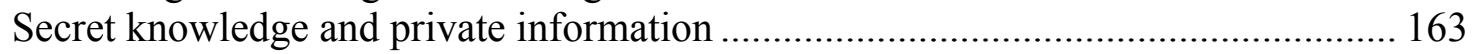

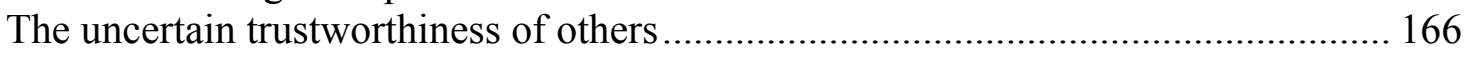

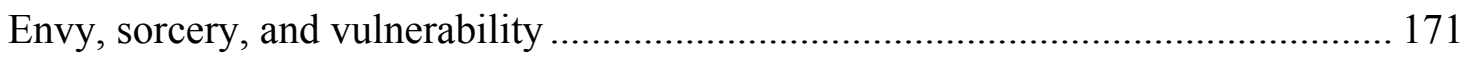

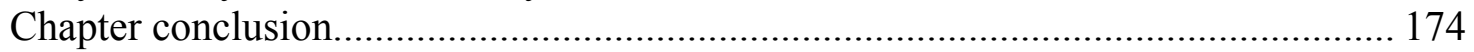

Chapter 5: Vulnerability ......................................................................................................... 176

Vulnerability, malicious spirits, and illness ....................................................... 181

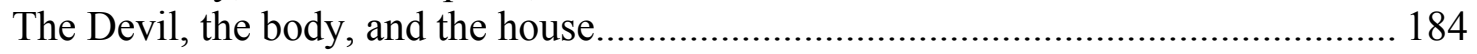

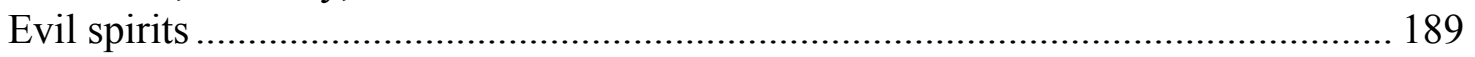

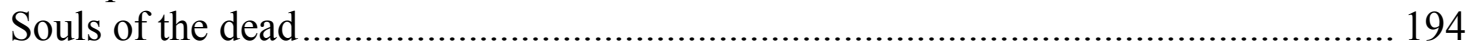

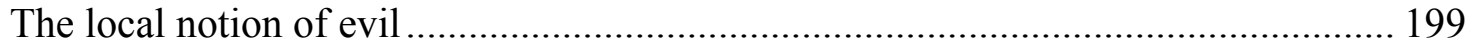

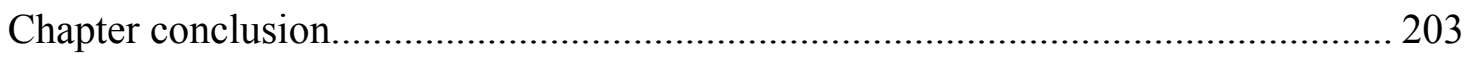

Chapter 6: Illness, Healing, and Sorcery ............................................................ 205

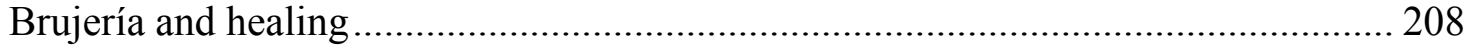

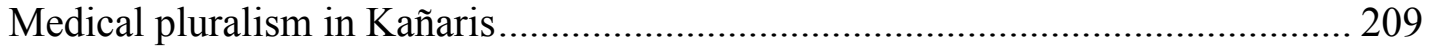

The interpretive arc of an illness............................................................... 213

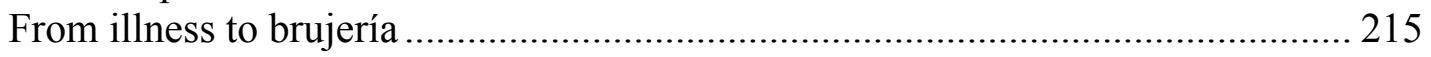

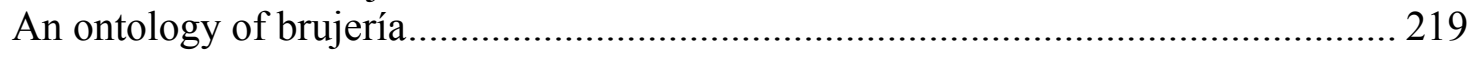

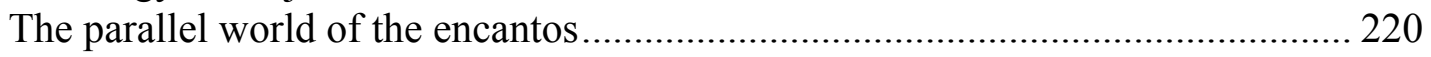

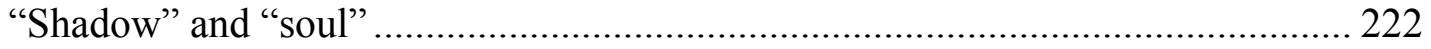

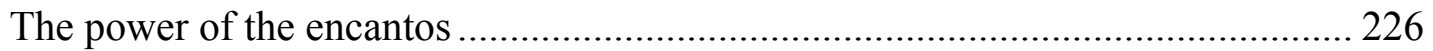

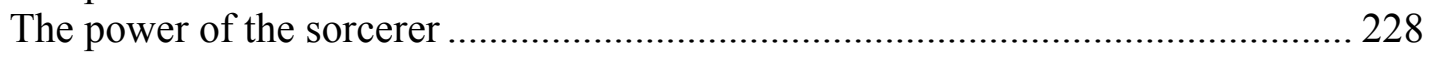

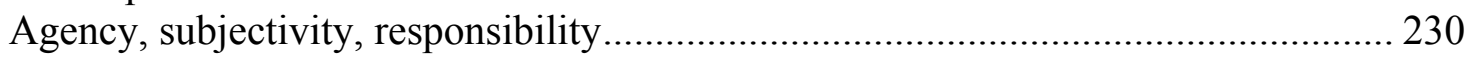

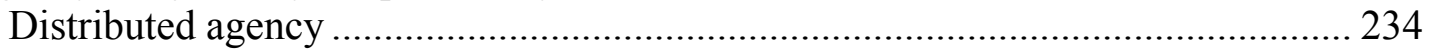

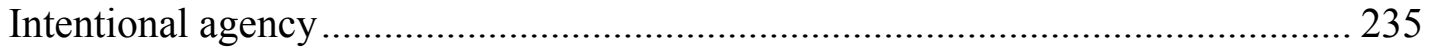

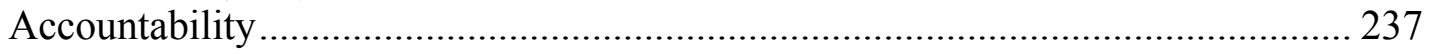

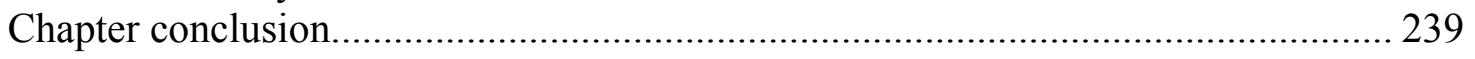


Chapter 7: Sacred Geography .......................................................................................... 242

The sacred geography of Kañaris .................................................................... 244

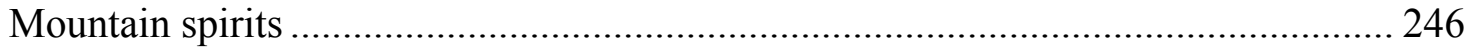

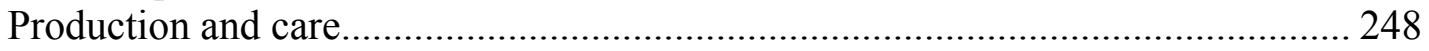

Dual capacity for generation and destruction ....................................................... 252

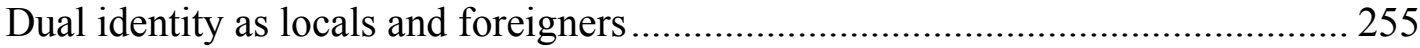

The historical roots of mountain spirits ................................................................ 257

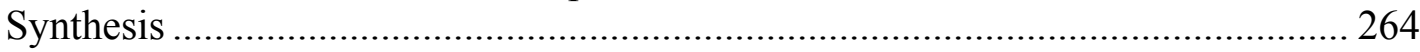

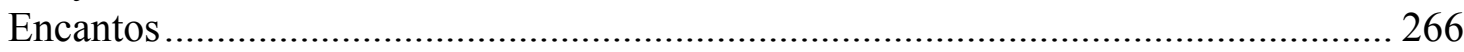

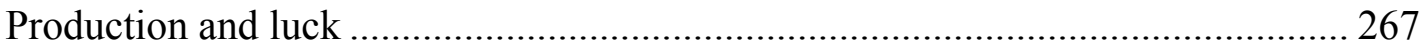

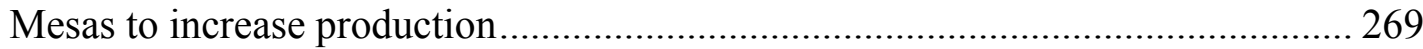

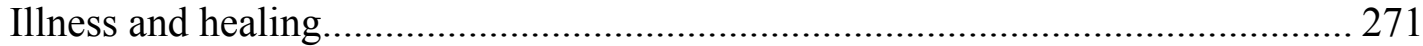

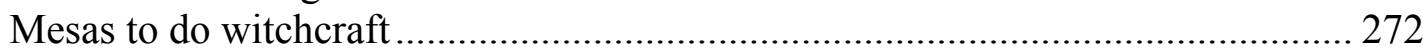

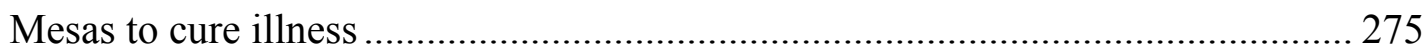

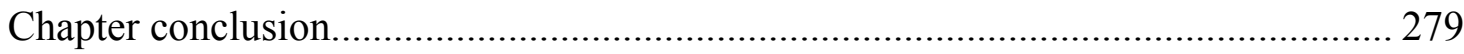

Chapter 8: The Mesa ……........................................................................................... 283

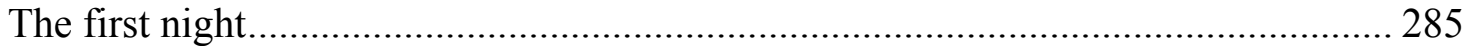

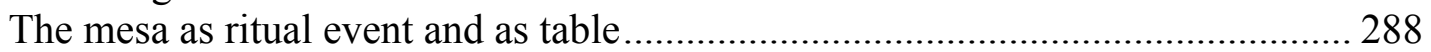

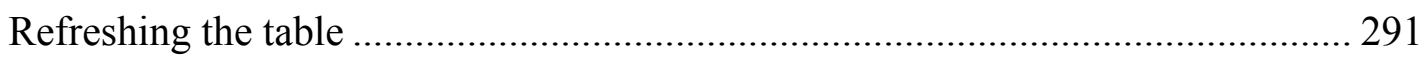

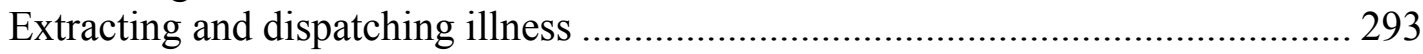

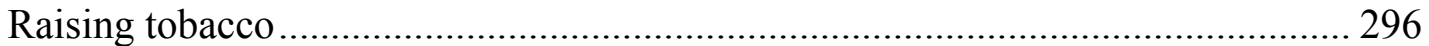

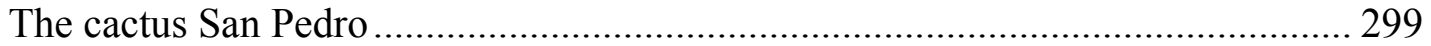

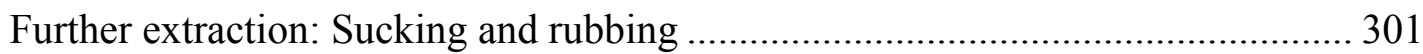

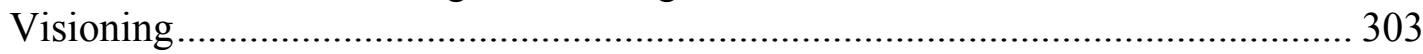

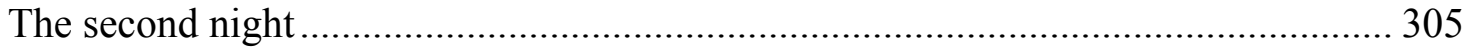

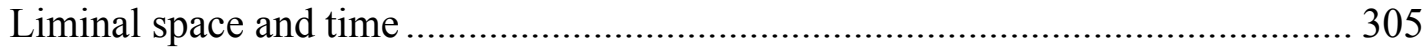

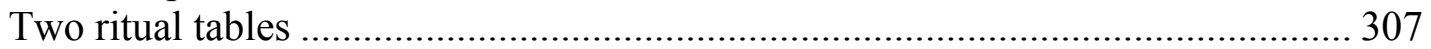

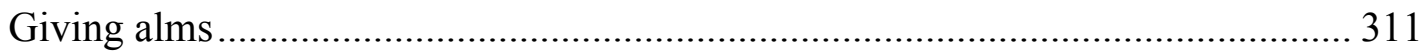

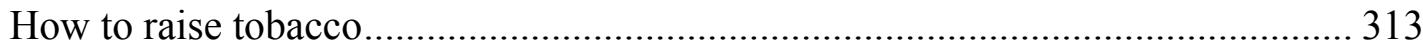

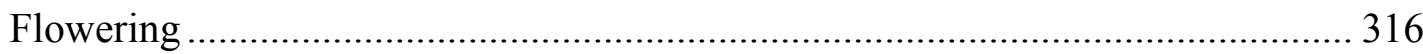

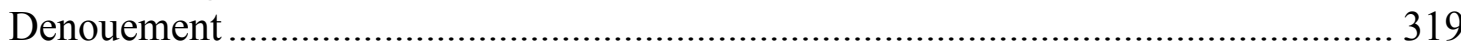

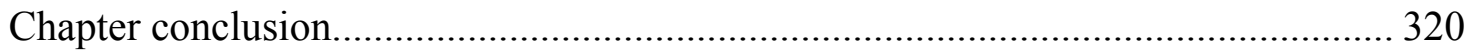

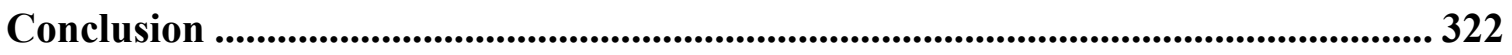

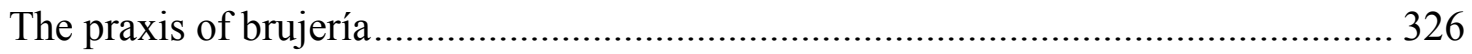

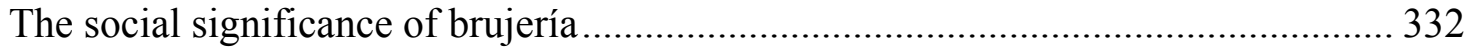

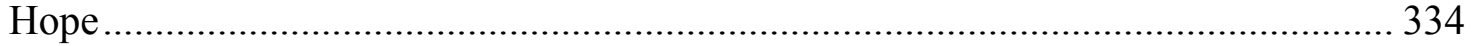

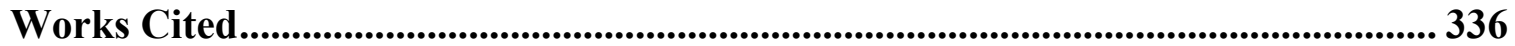




\section{List of Illustrations}

Figure 1: Map of Peru

Figure 2: Map of the Region of Lambayeque

$\mathrm{X}$

Figure 3: Map of the District of Kañaris

xi 
Figure 1: Map of Peru

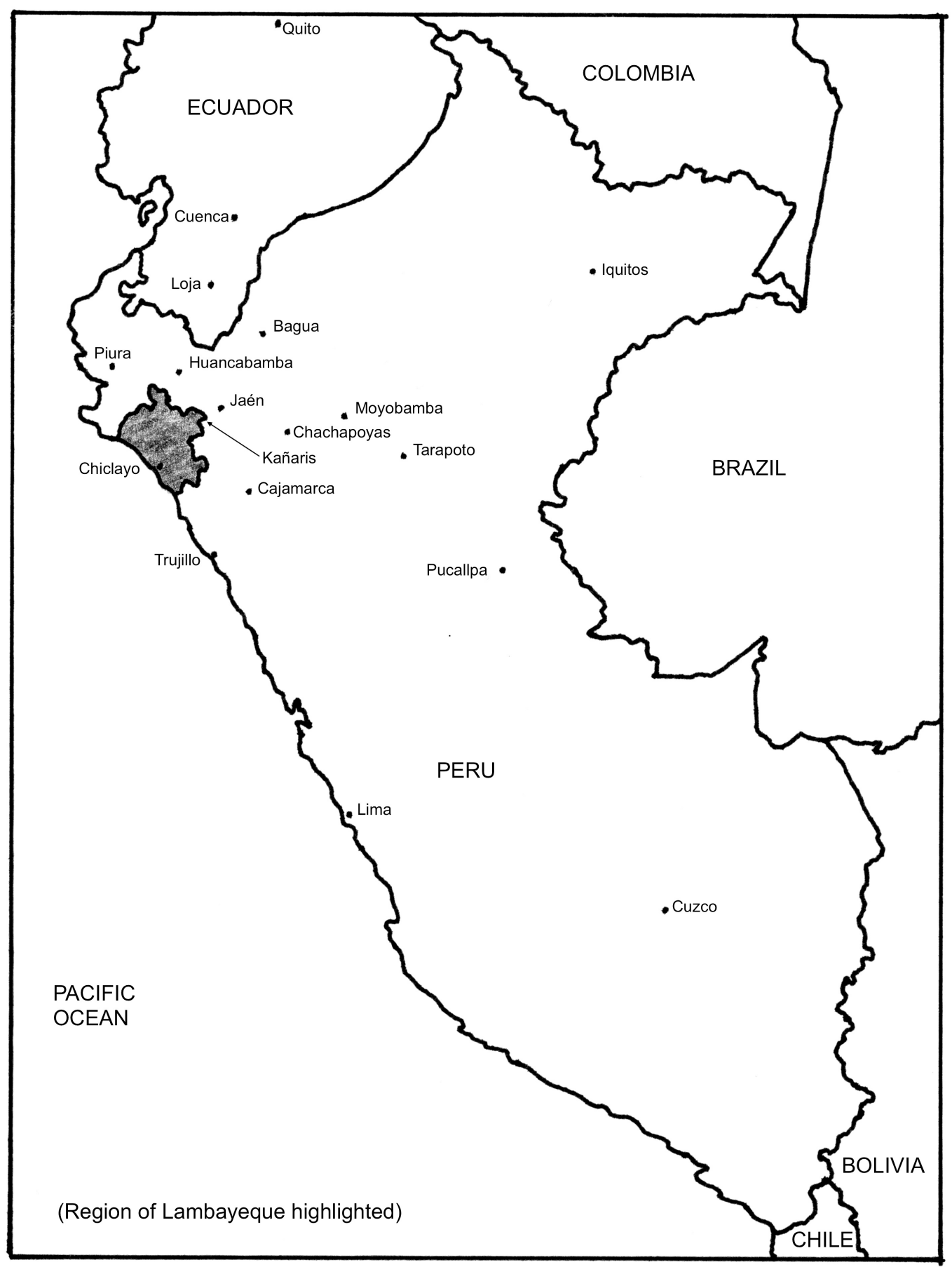


Figure 2: Map of the Region of Lambayeque

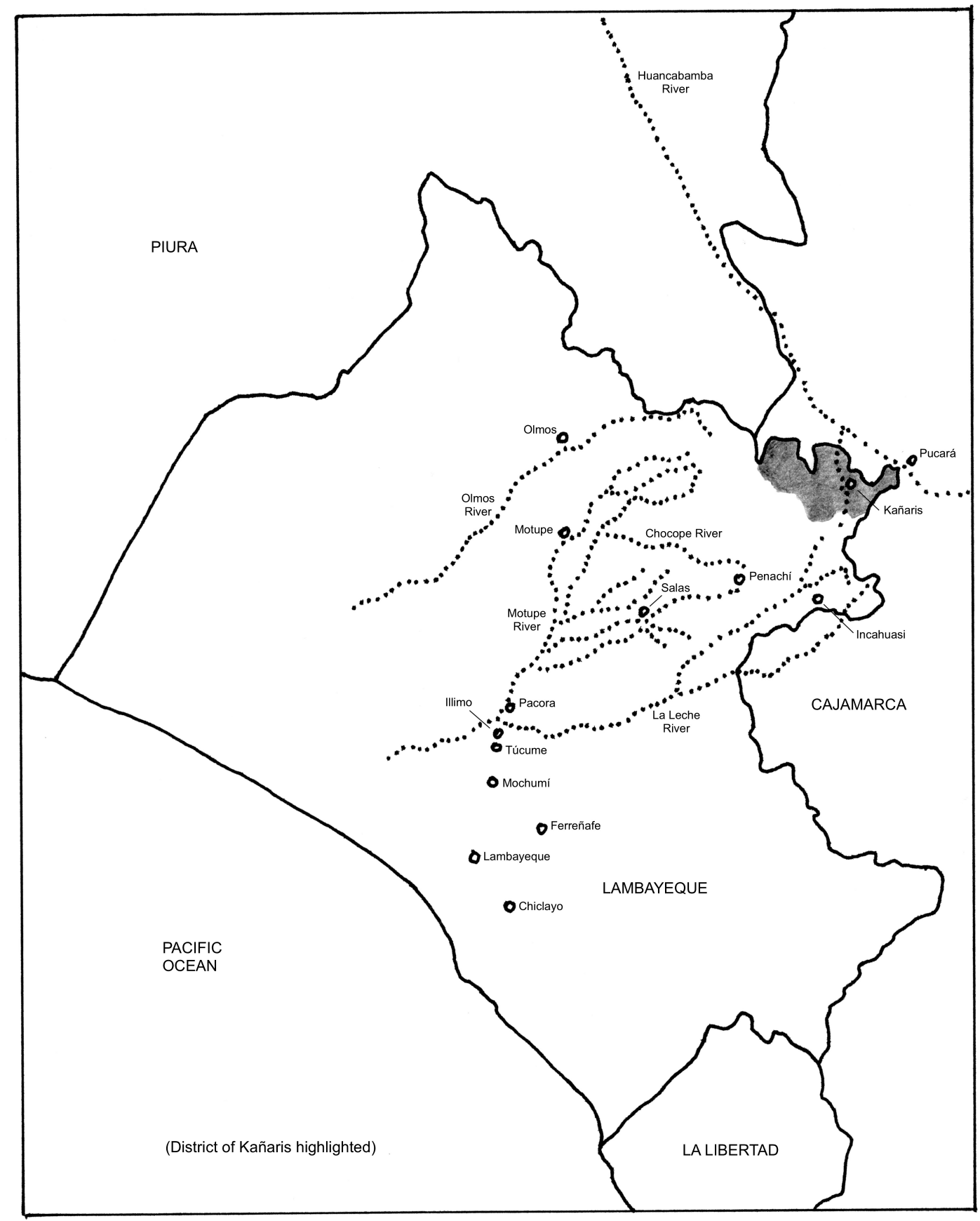


Figure 3: Map of the District of Kañaris

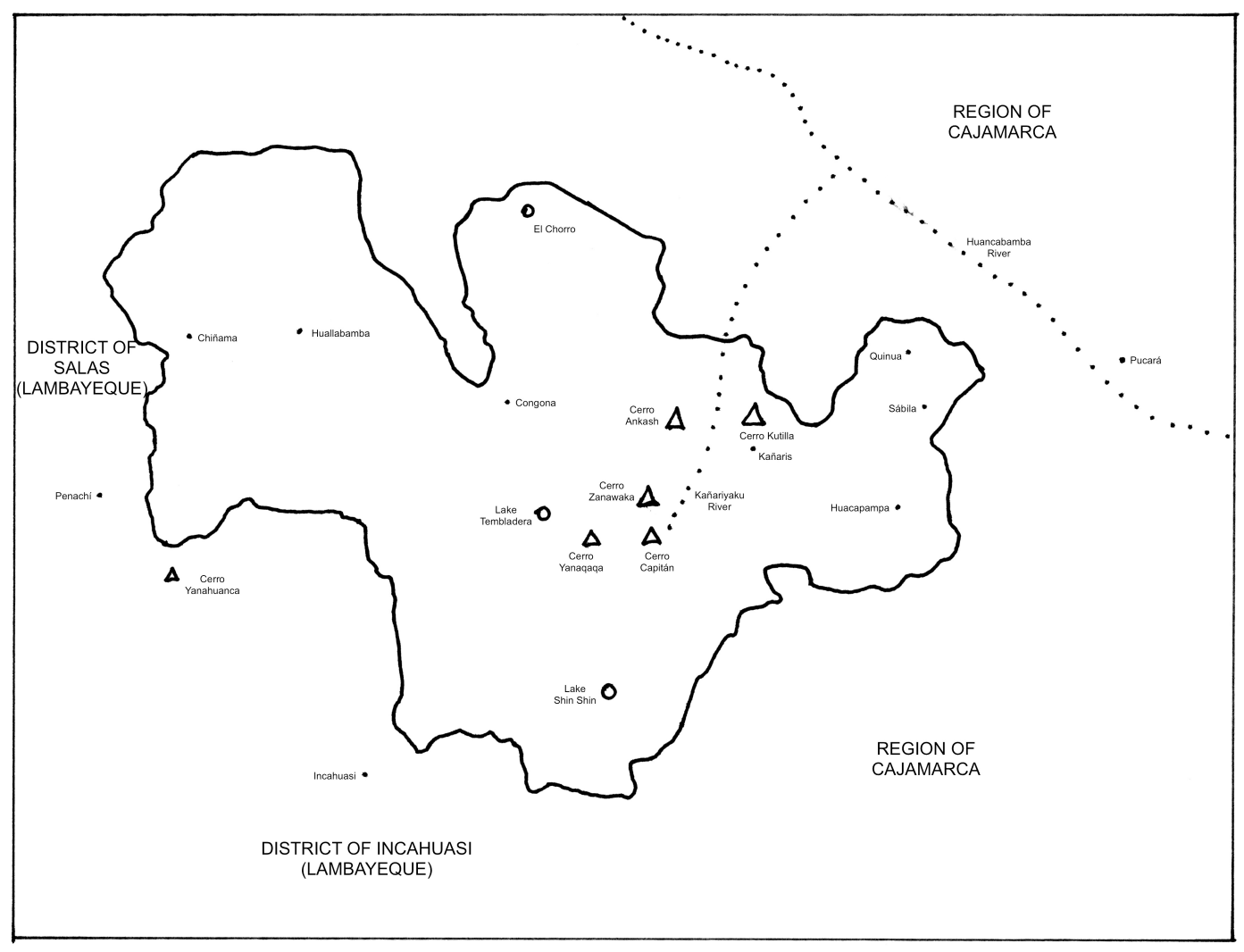

Map shows approximate locations of main landmarks discussed in the text. 


\section{Introduction}

Sorcery (brujeria, curanderismo) is a genre of both ritual healing and malicious witchcraft practiced throughout northern Peru. In the Andean community of Kañaris, practitioners call upon the power of place-based spirits called "enchantments" (encantos) to both cause and cure certain classes of illness. These spirits are embodied in particular mountains, waterfalls, and high-altitude lakes. People attribute each encanto with individualized names, identities, and capacities. They are repositories for a sacred power or energy that has the potential to both help and harm people, as manifested in a person's body, productive activities, and social relations. But in Kañaris, the encantos do not usually cause illness of their own intention or will. These place-based spirits do not interact with lay people directly. Instead, ritual specialists called "sorcerers" (brujos) or "masters" (maestros) mediate relations between people and place-based spirits. Therefore, moral responsibility for illness attributed to sorcery lies with the sorcerer, and the client on whose behalf he acts. People in Kañaris say that malicious witchcraft is always motivated by envy, and perpetrated by someone personally known to the victim. In this sense, sorcerers also mediate relations between fellow community members.

I went to Kañaris intending to learn about the ethnographic specificity and experiential efficacy of sorcery as a genre of healing. Through the process of fieldwork and writing, I realized that my research on sorcery is valuable because it gives us a window onto some of the things that deeply matter to people in Kañaris even though they 
are rarely said. Sorcery enables the participant observer to get at the mass of the iceberg of cultural meaning and understanding that lies below the surface of everyday life, seemingly invisible yet part of the foundation of this small-scale society. These things ultimately have to do with local ideas of ethics and correct moral conduct.

Since I only came to understand this in the process of writing, I have reserved an in-depth exploration of the local moral economy and ethical understandings (that is, the interrelations between moral values and social practices in the local context) for future research. The scope of this dissertation is more modest. I argue that sorcery matters to people in Kañaris for three key reasons. It accounts for and allows people to respond to their suffering and the unequal distribution of fortune. It enables people to modify their state of "luck," which helps them achieve their goals for household production and advancement. And it tells them something about their relations to fellow community members.

In the following chapters, we explore different aspects of Kañaranse society: the local conception of the community, the internal political structure and its regional context, the composition of the household, the practices that tie individuals and families to one another, and the issues that point to underlying social fractures (Chapters 1-3). Then we turn to how people manage uncertainty and vulnerability to misfortune and suffering in their everyday lives (Chapters 4-5). This sets up the discussions of illness and healing, how the power of the encantos works, and the practice of sorcery itself (Chapters 6-8). First, however, I outline the place of Kañaris and the practice of sorcery in regional context. 


\section{The road to Kañaris}

Early one morning, I took a small bus with Mercedes to Chiclayo. We passed by field after field of tall, green sugar cane, still quiet and cool in the morning mist. When we reached the city, we took a taxi and squeezed our way through the clogged streets to get to the bus station. We were fortunate to get two tickets on a larger, double-decker bus that was leaving in the next half hour.

I had been staying with Mercedes on the coast for the past three weeks. She was a schoolteacher from Kañaris, about fifty years old, with a broad smile and eyes that sparkled behind her rectangular glasses. Everyday I hoped she would say she was ready to return to Kañaris, and everyday she would say she had to run another errand or submit another piece of information to the Ministry of Education for her year-end reports.

Mercedes was the most self-professedly "modern" woman I ever met from

Kañaris. She had never married and lived alone. Her hair was cropped short and she wore pants and sweaters instead of long black skirts and colourful sateen blouses. Moreover, she rarely did agricultural work, and instead bought most of her food and other necessities with her salary. Although she was born in the district of Kañaris, she was not from the town itself. She was from a smaller hamlet several hours' walk away, where her mother and sister still lived. While she was distantly related to most people in the town, she had no immediate family members who lived nearby. This, along with the fact that she was a single woman without children, made her feel vulnerable. An outsider, an anomaly, in her own cultural setting.

Perhaps this was one of the reasons Mercedes was pleased to invite me into her home. She liked the company, meeting someone new, and being associated with a 
visiting foreigner. Most people from Kañaris would not trust an outsider so readily. She agreed to help me because she knew Dr. Rivera, a Peruvian anthropologist who had introduced me to her five months before.

The support of Mercedes and other people in Kañaris was crucial for people's cautious acceptance of my regular presence in their community over the next eighteen months. To the best of my knowledge, townspeople generally came to understand - at least in public - that I was a curious foreigner who did not intend to harm them. Yet even then, I am sure those from surrounding villages often suspected that I was a spy for a government, mining corporation, or other external agency, collecting information that could be used against them or the community as a whole. Other people seemed to plain dislike any outsider coming into their community and nosing around in their business, for whatever reason.

During the time I spent in Kañaris, I only talked with people who were willing to talk with me. I knocked on the doors of people whom others had already introduced me to, and I attended household and community events only when a community member invited me. Therefore, I became associated with some families and not others, and talked with some individuals more than others. To the best of my abilities, I demonstrated I was open to conversation with everyone in town. Yet from the moment I entered Kañaris, my interlocutors received me and interacted with me according to my position in the local social network. I was never a dispassionate observer, and I could never be a friend to everyone.

While the breadth of my knowledge of community members was limited by these social factors, I gained a deeper understanding of certain people and their families. Three 
people stand out in particular. My research would not have been possible without the trust, charity, and friendship of the people whom I call here Mercedes, Andrés, and Isabel. Mercedes was the first local who brought me to Kañaris and offered me a place to stay. Within a couple of months, I moved to the home of Andrés, Isabel, and their three school-aged girls. They lived in the same area of town as Mercedes, and I spent much of my time with them and their immediate family members.

It is difficult for an outsider to visit Kañaris. The town is located in the highlands of the region of Lambayeque, in the district furthest from regional capital of Chiclayo (refer to Figure 1). A Peruvian "region" or "department" is an administrative subdivision similar to a Canadian province or American state. Each region is divided into two or more "provinces," and each province is further divided into several "districts," which contains cities, towns, and villages. For example, Chiclayo is the capital of the region of Lambayeque, which is further divided into three provinces. Kañaris is one of six districts in the province of Ferreñafe, and the town of Kañaris is the capital of this district.

Chiclayo has all the amenities of a typical Peruvian city: electricity and indoor plumbing, telephone and internet connections, paved roads crowded with taxis and buses, grocery stores and outdoor markets, restaurants and clothing stores, even universities and an airport. A world away from the Kañaris, a two-day journey east over the Andean mountains.

There is no highway that directly links Kañaris to the coast. Travellers first take a bus from Chiclayo to the town of Pucará, five hours away in the valley formed by the Huancabamba River (refer to Figure 1). A dirt road climbs the forested mountains on the south side of this river to reach Kañaris. Locals either walk eight to ten hours up the 
district road, or wait in the valley town until they see a truck driver they know who is driving there. Four or five locals have transport trucks that make the trip several times a week.

Most people in Chiclayo do not know or care about Kañaris. When I inquired at the regional tourism office, no one was able to tell me how to get to the town. They did not even know it existed. I could only get to Kañaris by travelling with a local or someone who knew the way. This is also the only appropriate manner in which to enter the town. Kañaris is far off the beaten path, and it is rare to see either national or foreign tourists in the district. Representatives of the regional government, the Catholic Church, and nationals who work for Peruvian human rights and development organizations occasionally visit Kañaris. But a person who arrives in the town or surrounding villages without previous contact or a local introduction poses a risk to both themselves and others. As in many Andean communities, people in Kañaris regard community outsiders with deep suspicion. They fear the unknown visitor will bring harm to themselves and their families. From the local perspective, this fear is justifiable in the context of a weak central government, widespread political corruption, drug trafficking, and the experience of many Andean communities during the devastating guerilla warfare of the 1980s.

For my part, I did not want to risk travelling alone. Even though most of the people I had met in Peru were decent, respectful, and generous, no one advises a young white woman without any companions to travel to unknown areas. In both urban and rural settings, the important thing is to position oneself in such a way that people feel they will be censured or held socially accountable if they harm or take advantage of you. 
I was grateful that Mercedes had agreed to take me to Kañaris. She has a second house in a town close to Chiclayo, and she travels there whenever she has to visit the Ministry of Education, go to the bank, buy household supplies, and do other errands. I had travelled from Lima to stay with her, and when she had completed all her tasks, we left for Kañaris.

\section{Departing from the coast}

Mercedes and I bought our bus tickets in Chiclayo in the late morning. By this time, the cool morning breeze had completely blown off, replaced by the scorching heat of the coastal summertime. When we boarded the bus, we drew the blinds closed and opened the window by our seats to let cooler air circulate through the stuffy tin can. Once out of the city, the bus drove northeasterly, past the dusty rice packaging plants and sugar factories outside of Chiclayo.

Our bus was heading for a town named Olmos, and from there it would take the eastern fork to pass through the mountains (refer to Figure 2). We made good time, for the highway was wide and straight. The landscape was desert scrubland, all sandy dirt, scraggly trees, and tall cacti. One-story adobe brick houses were scattered to the side of the road, broken only by green patches wherever there was irrigation for a field.

As the bus drove on, we passed by what appeared to be a large hill incongruously towering over its flat surroundings. This was in fact no hill, but an ancient, eroded adobe step pyramid temple and burial mound, made long before the arrival of the Incas and the Spanish. 
The bus passed the pre-Incan funerary temple and continued along the highway to the town of Motupe (refer to Figure 2). This is the site for the regionally famous Cruz de Chalpón, more commonly called the Cruz de Motupe. Every August thousands of pilgrims from near and far descend upon this town to hike up a mountain where a cross is kept in a protective glass case in a stone grotto. Both rural and urban Peruvians attribute the Cruz de Chalpón with healing powers, and the faithful come to ask for healing and blessing (Vreeland 1991: 231). The cross was allegedly made in the mid-nineteenth century by a mendicant monk known as Brother Juan de Abad or Father Guatemala (Fernández Alvarado 2008: 9-10; Sevilla Exebio 2005: 38; Vreeland 1991: 232-233, 253n8). It is said to have two "brother" crosses at Cerro Rajada (or Rajado, also near Motupe) and Cerro Yanahuanca (near Penachí) (Sevilla Exebio 2005: 38; Vreeland 1991: 233).

On my preliminary visit to this area the previous August, I attended the festival of the Cruz de Yanahuanca in Penachí (see Rivera \& Sax 2011). Pilgrims had also come for blessing and healing, and people similarly told me that the Cruz de Yanahuanca is one of three "brother" crosses made by the mysterious monk. While the Cruz de Chalpón attracts many urban pilgrims to Motupe, the festival of the cross in Penachí is a more local event. The attendees and practices surrounding the festival resonate with what I later observed in Kañaris, as situated in a distinctly "Andean" ritual understanding and practice. Special groups of male dancers hiked up a mountain to the site where the cross was brought down from Cerro Yanahuanca by another group of men. The dancers then spent two days dancing down the mountain to bring the cross to the town. 
Penachí is on the western edge of the Andes. Mountains rise up to the east of the town, one of which is Cerro Yanahuanca. On the other side of this mountain is the district of Incahuasi. Kañaris is directly to the north of Incahuasi (refer to Figure 3). Although there is no road that connects the three communities of Penachí, Incahuasi, and Kañaris, they have had contact at least as far back as the Spanish colonial period. Yet if this area was part of a wider socio-cultural or political group in the past, these connections have been forgotten today.

\section{A unique geographical region}

After Motupe, the highway turns away from the coast and towards the mountains. We left the cactus-spotted scrubland behind, and headed towards green hills bringing a fresh breeze. The road twisted and turned, slowly climbing up and around the mountains. The highway takes a roundabout route to reach Kañaris in the extreme northeastern corner of the region of Lambayeque.

The highest point in the highway passes through mountain peaks that are often shrouded in misty clouds. These peaks do not traverse high-altitude plains, which are typical of such mountain passes in the southern Peruvian Andes. At an altitude of less than 3000 metres above sea level, the hillsides are still lush with trees and other thick vegetation. The mist and clouds are due to humidity that rolls in from the Amazon jungle and gathers on the eastern side of the mountains. Unable to pass over the peaks, the clouds are forced to release their precipitation, which results in moister eastern slopes and drier western ones. 
The three major ecological regions of Peru (Costa! Sierra! Selva!) meet in places like this. The western side of the Andes is dominated by a dry, coastal climate. There are many microclimates in the steep slopes and valleys between mountain ranges, cooler at higher altitudes and warmer in river valleys. The eastern side of the mountains is verdant and humid, and becoming ever more so as one descends in altitude and draws closer to the jungle.

This particular mountain pass is important for another reason. It is along the most direct, lowest altitude route from the northern coast to the Amazon basin (Vreeland 1993: 182). Our bus was crossing a geographic region characterized by an uncommon break in the three parallel mountain chains that make up the Andes. In southern Peru, the Western, Central, and Eastern Ranges are formidable walls that separate the coast from the jungle. But here, in between northern Peru and southern Ecuador, rivers cut wide corridors through two of these mountain chains. Only the Western Range closest to the coast remains unbroken (Weigend 2002: 39). The district of Kañaris is located in the centre of this geographical region, on the western slope of the Central Andean Range.

According to biologist Maximilian Weigend, the break in the other two Andean mountain ranges creates a unique "biogeographical" transitional zone, with many species of flora and fauna that are only found in this area (Weigend 2002: 46-53). The zone is comprised of many diverse, island-like habitat fragments (Weigend 2002: 52). The most notable of these are the "relict forests," high-altitude cloud forests that are remnants of what was once a larger continuous forest covering northern Peru and southern Ecuador (Weigend, Rodríguez, \& Arana 2005: 186). 
The district of Kañaris has the single largest relict forest in this zone, an estimated 13,800 hectares, which accounts for more than a third of the entire area of such forests in northwestern Peru (Llatas Quiroz \& López Mesones 2005: 306; Weigend, Rodríguez, \& Arana 2005: 189-191). Biologists call this the Upaypiteq Forest, and it plays a crucial role in regional watersheds, providing water not only for Andean communities, but also cities and plantations on the arid coast. As far as I know, the only law that protects the Upaypiteq Forest is that it pertains to the peasant community of Kañaris.

\section{The halfway point}

Once we passed over the mountains, our bus followed the northern edge of the Huancabamba River to a valley town called Pucará (refer to Figure 2). A couple thousand people live in in this town, but there is no central bus station. Our bus stopped on the side of the highway before continuing east to the city of Jaén.

Mercedes and I had arrived after four and a half hours - five if the bus were to stop at a restaurant along the highway for lunch, as it usually does. This is as close as a paved road gets to Kañaris, still distant in the forested mountains on the southern side of the Huancabamba River.

One of Mercedes' brothers has a house in Pucará, so we did not have to wait in the street or find a hotel room as I would have to every other time I travelled. We took a three-wheeled motorcycle taxi to the house, where Mercedes' mother greeted us. She had come down from her farm in the mountains. Mercedes wanted to buy her mother some new sandals and food staples in the market. But the most important thing she had to do was visit her father's grave. 
Mercedes, her mother, and I walked through the town, heading for a bridge that leads to the cemetery on the other side of the river. As we approached the bridge, we saw a group of men coming over. Among them was one of Mercedes' neighbours in Kañaris. After greeting her neighbour and asking if he knew if a truck driver was headed to Kañaris, Mercedes asked him what he was doing in town. He told her he had come to consult a "curioso," a curious person, to treat a family member's illness.

A "curioso" is someone who is personally motivated to learn about ritual healing and the spiritual world. It is also a euphemism for a sorcerer. Mercedes jumped on the opportunity to ask if we could come along. Her neighbour smiled shyly and immediately backtracked. He said he did not believe in sorcery, and he was not actually going to consult a sorcerer.

"He surely was going to visit a curioso," Mercedes said after her neighbour departed. "He just didn't want to tell us."

We continued over the bridge, walking up a dirt road dotted with small houses to arrive at the cemetery. We went to light candles at the grave of Mercedes' father. Like most other graves, it consisted of a wooden cross, engraved with his name and date of death, and propped up by a pile of rocks. Mercedes' father had died when she was in her early twenties. She told me she had been very close to him, and had suffered greatly by having to make her way in the world without him.

It was mid-afternoon, with the sun hot and high in the sky. We crouched in the bit of shade provided by the nearby cemetery wall. Mercedes told me about the circumstances of her father's death with great emotion. 
"He died because of the stress of a land dispute. My evil uncles wanted to take his land away," she said. "I visited him in the morning, and he looked fine. When I came back after work, he was very sick."

Her family carried him down the mountain to the medical post in Pucará. The doctor said there was nothing to do to save him. They could keep him on life support but he would "be like a vegetable." Mercedes was not ready to give him up and wanted to bring him to the hospital in Chiclayo. But he died when she was arranging the taxi. Since he died in Pucará, he was buried there instead of Kañaris. To this day, Mercedes blames her "evil" uncles for her father's death. Nevertheless, she always emphasized that his sudden passing was due to stress, and not sorcery.

Still, she believes in the intercession of the dead through dreams. "At least, when it's convenient to me," she said, half-laughing at herself.

When dreaming, a person can see future events and have contact with deceased relatives. For example, Mercedes' cousin had a premonitory dream about her family shortly before her father's death, indicating that something bad would suddenly befall the family. Mercedes also told me her father intervened on her behalf several times, ensuring her success in particular events. The first of these was the land litigation against her uncles shortly after his death, which her family won. Her father used to visit her in dreams, and she would ask him to help her in a given matter — much as one would pray to a Catholic saint, and as she instructed me to ask him as I lit a candle on his grave.

"But he doesn't visit me now," Mercedes said. "I wish he would, because I miss him." 


\section{Ascending the mountain road}

The following afternoon, Mercedes found a truck that was going to Kañaris. At that time, there was no vehicular bridge that crossed the Huancabamba River to connect Kañaris and the highway by the most direct district road. Truck drivers either had to take a different bridge that took an indirect route to the town, or stay on the northern side of the river and carry jerry-cans of gasoline to their vehicles over a hanging walking bridge. Six months later, a new concrete bridge was completed beside this one. Trucks could then cross over the river to stock up on gas and store goods, as well as pick up passengers right in Pucará. But in January 2011, there was only the old hanging bridge.

Mercedes, her mother, and I took a motorcycle taxi to this rickety wooden bridge outside of Pucará. The wind ruffled our hair and threatened to whip off our hats as we flew down the highway, past rice paddy fields and a clear blue sky stretching across the valley. We got off at the fruit stands that mark the bridge, and walked with our bags over it to meet the truck waiting on the other side.

The back of the small transport truck was already packed with parcels and people. Mercedes said goodbye to her mother, who would walk up the mountains to her farm herself. There was one seat left in the front carriage for Mercedes, and I climbed in the back with our bags. It was full of potatoes, sweet potatoes, onions, apples, buns, packaged cookies and crackers, six-packs of soda pop, and about twenty people with their own bags. Women and children sat on the ground, men stood holding onto the sides of the truck and a central top-rail, and older boys perched on top of the truck cabin. There was no room to sit, barely enough to stand, and despite my best efforts I alternated 
between squishing a giant sack of tomatoes and standing on a plastic crate of live chickens.

It was generally fun, and the weather was pleasant - sunny and dry. Except for a few puddles, the condition of the dirt road was good. We were fortunate it had not rained in the past couple of days, for while it is hot and dry on the coast, it rains most days in Kañaris this time of year. The following January I was not so lucky, as heavy El Niño rains washed out the roads, preventing safe travel for several weeks.

The truck crawled upwards at about ten kilometres an hour, bumping over potholes and winding around large stones. The narrow, zigzagging road hugged hillsides that looked over steep cliffs, and cut under tree-lined canopies. We passed several hamlets, letting some passengers off. In Chilasque it was blazing hot, and everyone bought homemade popsicles from a household store to cool off. We passed through Pampa Loma and Atumpampa, where the road was lined with orange and coffee trees. Tute was higher up, with an expansive view dotted with corn fields.

We forded a stream and faced cooler air, brisk enough to pull on sweaters and shawls. Our truck climbed ever higher along the steep dirt road. The surrounding hillsides were thick with trees, the nearest ones draped with moss and spotted with huge, leafy bromeliads held in the crooks of their branches. Some of the trees were not trees at all, but actually giant, woody, ferns. The ground was layered with smaller shrubs, saplings, ferns, and other forest undergrowth.

We were travelling away from the Huancabamba River, into the northeastern corner of the district of Kañaris. The area is covered with rolling mountains, humid forests, and low river valleys. The eastern and western halves of the district are separated 
by the dense and mountainous Upaypiteq Forest. The southern region is dominated by high-altitude wetlands that cross over to the district of Incahuasi in the southwest, and the region of Cajamarca in the southeast (refer to Figure 3).

Although several drivable roads link the district of Kañaris to the outside world, they do not usually meet up with one another. In the western half of the district, roads connect the Chiclayo-Olmos-Jaén highway to towns such as Chiñama and Huallabamba. In the east, one road goes to the town of Kañaris, and another to Huacapampa (see Municipal Distrital de Kañaris n.d.; refer to Figure 3). While no vehicle road links the western and eastern halves of the district, it is crossed by a series of footpaths. The district population is more concentrated closer to the northeastern and western borders, where the mountains descend to warm and dry river valleys, and the dirt roads meet up with the paved highway.

The distance between Pucará and the town of Kañaris cannot be more than fifty kilometres. But because of the rough condition of the road - which is perilous even at the best of times - the journey takes about four hours. The truck plodded along like an old beast that knew every dip and turn. Finally we turned a corner and found the road lined

with tall, fragrant eucalyptus trees. Through the branches I glimpsed a green hillside, then a steep valley descending to the Kañariyaku River, and the lower fields around the town rising up on the other side. We turned one last corner, and arrived in the town of Kañaris.

\section{Why Kañaris?}

I chose Kañaris as my fieldsite through both intention and serendipity. I had done my Master's research on Andean agricultural and pastoral rituals in the Peruvian region 
of Huancavelica (see Sax 2011). I wanted to investigate ritual healing for my Doctoral research, and I knew that northern Peru was famous for sorcery. While existing ethnographies focus on the practice of sorcery on the coast (Glass-Coffin 1998; Joralemon \& Sharon 1993; Sharon 1978), there is no published research on sorcery in the northern Peruvian Andes in English (for Spanish ethnographies, see Arroyo Aguilar 2004; Camino 1992; Polia 1996). I wanted to find a fieldsite in the "health axis" described by Peruvian anthropologist Lupe Camino (1992: 44; see also Bussman \& Sharon 2006), an area stretching from Loja in southern Ecuador to Cajamarca in Peru, and traversing the highlands and eastern side of the Andes that descends into the Amazon jungle.

In the summer of 2010, I was in Peru doing archival research for my $\mathrm{PhD}$ supervisor, Peter Gose. He put me in contact with Juan Javier Rivera Andía, a Peruvian anthropologist conducting research in the highlands of Lambayeque. I accompanied Dr. Rivera on one of his field trips, travelling to first Penachí and then Kañaris. He introduced me to Mercedes, Andrés, and other people in the town.

Kañaris was an ideal place for me to base my research because it was a rural highland community where people practiced sorcery and I now had contacts. It was situated in an Andean area with well-travelled roads to both the coast and the jungle, squarely in the middle of Camino's "health axis." Furthermore, while a handful of foreign and Peruvian scholars have visited the district for biological and archaeological research (Fernández Alvarado 2008; Llatas Quiroz \& López Mesones 2005; Weigend 2002, 2004), only one anthropological paper has been published specifically on Kañaris (Alva Mariñas 2008). More anthropological research has been carried out in the 
neighbouring districts of Salas, Penachí, and Incahuasi, which are more easily accessed and better known to Peruvians (see Sevilla Exebio 1998, 2005; Taylor 1996; Vreeland 1991, 1993).

As a place few people knew of and even fewer had visited, the district and town of Kañaris fulfilled the romanticized prerequisites for a fieldsite I held at the time. But it also offered me the potential to make a meaningful scholarly contribution, and to fill a gap in the existing ethnographic literatures of the Andean cultural area ${ }^{1}$ and the practice of sorcery in northern Peru. Since so little scholarly work has been published on the highlands of Lambayeque, in the following section I provide a brief history of the area, and how there came to be a community called Kañaris in this region, with a population who self-identifies as distinct from their neighbours.

\section{Kañaris in historical context}

Fifteen or twenty years ago, community leaders were invited to the Ecuadorian province of Cañar for intercultural exchange. They brought back a rock and placed it in the wall of the municipal building in the town of Kañaris, to "remember our Cañar brothers," as one of the participants told me. Townspeople soon forgot about it, however, and plastered the rock over. Then in 2011, the municipal council invited a group of Cañar musicians to play at the annual festival of the town's patron saint. When the musicians greeted the crowd, they evoked a notion of common indigenousness to suggest they are related. The Kañarense onlookers were not interested in this, however. They politely

\footnotetext{
${ }^{1}$ To the best of my knowledge, the only published works systematically comparing ritual tables in southern and northern Peru are Fernández Juárez 1997, 2010.
} 
listened to their music, but what they really wanted to hear was the second musical group, who came from the nearby region of Cajamarca. Locals later told me they found the Cañar musicians strange, speaking a different dialect of Quechua and dressing in an exotic manner. They were especially shocked by the men's long hair. This is a clear sign of indigeneity in Andean Ecuador, but it is foreign in Andean Peru.

Kañarenses in northern Peru do not consider themselves to be related to the Cañar of southern Ecuador, and they are not persuaded to build ties to other communities because of their shared "indigeneity." Community members do not act politically and socially on the basis of their ethnic identification. The vast majority of locals are not interested in accomplishing their macro-political goals alongside other "indigenous" groups, whether they are in another country or in the neighbouring district of Incahuasi.

Yet locals call themselves "Kañarense," and not just because they live in the town and district of "Kañaris." Some people who live in the town consider themselves Kañarense, while others do not. Kañarenses are people who self-identify, and are identified by others, as members of the interrelated families who have lived in this district since as far back as they can remember. I will return to the autopoeisis - or self-fashioned ethnic identification - of the community in the following chapter. In this section, I address how and why the name "Kañaris" arrived in northern Peru. Partly this is because of historical contingency, partly because of how people were categorized and positioned in the colonial era, and partly because of how people choose to position themselves in the modern nation-state today.

Here I follow the local convention and identify the population and community in northern Peru as "Kañaris." I use "Cañar" for the contemporary Ecuadorian community, 
colonial tributary populations, and the pre-Columbian group. There is a population who self-identifies as "Cañar" in southern Ecuador (see Blankenship 2005; Burgos Guevara 2003; Hirschkind 1995). The people in Kañaris consider themselves an independent group distinct from these Ecuadorians who bear a similar name. They also do not consider themselves the direct descendants of the pre-Columbian people who bore this name. Nevertheless, a brief detour through history is necessary to explain how "Kañaris" came to be associated with the place and population in the northern Peruvian highlands, even if most Kañarenses today do not consider it the foundation of their community.

\section{Incan conquest and resettlement}

The name "Cañar" originates in the fifteenth-century expansion of the Incan Empire. The Incas used this proto-ethnic identifier to name a group they conquered in what is today southern Ecuador (Hirschkind 1995: 315ff; Miño Grijalva 1982: 90; Oberem 1974: 264; Oberem \& Hartmann 1979: 373). According to anthropologist Lynn Hirschkind, the Cañar were a relatively dispersed population of loosely affiliated chiefdoms or tribes, each with a territory defined by a particular watershed, located primarily in the present-day Ecuadorian provinces of Cañar and Azuay (1995: 315-316; see also Miño Grijalva 1982: 80; Oberem 1974: 264). Hirschkind argues that they came to be discursively identified - and to an extent politically consolidated - as the "Cañar" only once the Incan Empire began to expand northward into their territories in between 1460 and 1490 (Ibid.; see also Hayashida 2006: 249; Miño Grivalja 1982: 93; Oberem 1974: 264; Rostworowski 2001: 257-262). 
Whether the Incas subjugated the majority or only a portion of the Cañar population is unclear (Oberem 1974: 264), but they continued to pose a rebellious threat (Hirschkind 1995: 320). This appears to be the primary reason that the Inca Túpac Yupanqui and his son and successor, Huayna Capac, relocated thousands of Cañar people as colonists to the south, and partially repopulated their territories with settlers more loyal to the Inca (Hirschkind 1995: 321-322; Miño Grijalva 1982: 90-93; Oberem 1974: 264; see also Murra 2002: 61; Rostworowski 1999: 244-247). According to Hirschkind, the Incas resettled more than seventy thousand Cañares in different parts of the Empire during the four to six decades between their subjugation and the arrival of the Spanish (1995: 323).

Early Spanish colonial documents record Cañar populations in Quito, Cuzco, Lima, La Paz, and in smaller towns throughout Ecuador, Peru, and Bolivia (see Crespo Toral 2003; Espinoza Soriano 1978a, 1978b; Hirschkind 1995: 322-323; Miño Grijalva 1982). Incan resettlement is the most likely way that Cañar people arrived in the highlands of northern Peru - or at least, it is a plausible explanation for why this protoethnic identifier was used to refer to people in this place in the Spanish colonial era.

Other people also lived in the highlands of present-day Lambayeque, such as the Guambos and Guayacundos (see Huertas Vallejos 1991: 491-492; Ramírez 1987: 581$582,586)$. Thus any Cañar peoples forcibly resettled to this area by the Incas did not move into an empty landscape. Given the century of upheaval that followed, it is plausible that some intermarried with whomever else lived there, and others moved to other areas and took on different proto-ethnic identifiers. For example, the region had 
recently seen the defeat of two coastal kingdoms - the Lambayeque/Sicán ${ }^{2}$ were supplanted by the Chimú/Chimor around 1350, and the Chimú were conquered by the Incas around 1470 (see Dulanto 2008: 762; Moore \& Mackey 2008: 789, 801). According to Peruvian historian Lorenzo Huertas Vallejos, northern Peru also experienced ongoing population movements due to earthquakes, droughts, and the El Niño climatic phenomenon that characterize this region (see Huertas Vallejos 1987, 1991).

Historians further argue that significant demographic changes took place in northern Peru in the early sixteenth century (see Cook 1982). Susan Ramírez estimates that even before the arrival of the Spanish, up to fifty percent of the coastal and highland population had died from internal warfare and European diseases travelling south from Mesoamerica (1987: 593). The Incan Empire was in the midst of major political upheaval. The Inca Huayna Capac had died sometime between 1524-27, likely of smallpox or another viral disease brought by Francisco Pizarro on an earlier expedition to present-day Panamá (see Gose 2008: 37; Kláren 2000: 34; Ramírez 1987: 593). Since no clear heir to the throne had been declared, a war of succession broke out between two of his sons: Atahualpa, based out of Quito, and Huascar, who was backed by the Incan elite

\footnotetext{
${ }^{2}$ This group used to be called the "Mochica" because of their language. The Mochica language disappeared only in the early twentieth century, and a group identified in Spanish colonial documents as Mochica or Muchic persisted into the seventeenth century (Espinoza Soriano 1975: 246-248). Today this group is more clearly identified as either Lambayeque (after the mythical founding hero, Ñaymlap) or Sicán (after a major archaeological site). This is because "Mochica" is often confused with the more ancient northern coastal culture called "Moche" (ca. 200 BCE - 850 CE), famous for the Huaca del Sol, Huaca de la Luna, and their fine ceramics (see Castillo Butters \& Uceda Castillo 2008). Some archaeologists still use the term Mochica for the Lambayeque/Sicán. To further the confusion, others use the term Mochica to actually refer to the Moche, particularly in Peru. For the sake of clarity, I follow the convention laid out in the Handbook of South American Archaeology (Silverman \& Isbell 2008), and refer to the fourteenth-century northern coastal kingdom as the Lambayeque/Sicán.
} 
in Cuzco (see Crespo Toral 2003: 280; Fauria 1989: 47; Gose 2008: 37; Hirschkind 1995: 323, 325; Oberem 1974: 265).

In 1532, Atahualpa defeated and executed his half-brother Huascar (see Gose 2008: 39). He also severely punished the northern Cañar, whose leaders had sided with his rival (Crespo Toral 2003: 281; Hirschkind 1995: 325). A Cañar chief had doublecrossed Atahualpa, feigning allegiance while spying on him for Huascar (Crespo Toral 2003: 280; Oberem 1974: 265). Atahualpa destroyed their primary city, Tomebamba (or Tumipampa; the site of present-day Cuenca), and slaughtered every Cañar he found, including a large contingent of women and children who had been sent to ask for his pardon (see Hirschkind 1995: 325; Oberem 1974: 265-266). His potential control of the Empire would be short lived, however, because this was the same year the Spanish arrived.

Spanish conquest and colonialism

Several commentators assert that it was specifically Cañar representatives who approached Francisco Pizarro when he landed at Tumbes in the northern reaches of the Incan Empire in 1532 (Crespo Toral 2003: 281; Hirschkind 1995: 327; Oberem 1974: 264, 267-270). It had been only about sixty years since the Cañar had been subjugated by the Incas (Hirschkind 1995: 327-328). It is easy to imagine that many Cañar wished to undermine Atahualpa and liberate themselves from Incan rule. Whatever their motivations, Cañar people supported the Spanish on a case-by-case basis under the leadership of particular chiefs (Hirschkind 1995: 327-328; Oberem 1974: 267-268). They aided Pizarro and his 168 men "as soldiers, guides, intelligence agents, and porters" 
(Hirschkind 1995: 328; see also Gose 2008: 36, 39; Oberem 1974: 266-270). Some Cañar accompanied Pizarro to Cajamarca, where the Spanish ambushed and captured Atahualpa (Gose 2008: 37-39; Hirschkind 1995: 327; Oberem 1974: 267). Other Cañar marched with Pizarro's men to take Quito and Cuzco, provided aid to the Spanish during the Incan sieges on Cuzco and Lima in 1536-37, and fought with the royalists in the Spanish civil war that broke out in the 1540s (Gose 2008: 42; Hirschkind 1995: 327-329; Oberem 1974: 267-269).

The Spaniards' capture and execution of Atahualpa in 1532-33 precipitated the fall of the Incan empire (see Gose 2008: 37-40ff). The Spanish prevented resettled groups such as the Cañar from returning to their ancestral territories, as it would have created serious administrative difficulties (see Hirschkind 1995: 328; Rostworowski 1999: 247; cf. Oberem \& Hartman 1979: 384). They rewarded specific groups who had aided them in the Incan conquest and Spanish civil wars. For example, Cañar in Cuzco were given the responsibility of guarding and policing the city, and continued to act as soldiers and messengers for the Spanish (Oberem \& Hartman 1979: 386). The Cuzqueño Cañar benefitted from this privileged position and exemption from labour tribute until 1692 (Crespo Toral 2003: 282; Oberem \& Hartmann 1979: 386).

Peruvian historian Waldemar Espinoza Soriano also notes the remarkable case of the Cañares in Chiara (Huamanga/Ayacucho), whom the Spanish exempted from labour tribute "in perpetuity" for having fought with the royalists in the Spanish civil war in 1542 (1978a: 324-325). The Spanish courts reconfirmed this exemption in 1568, 1572, 1595, 1636, 1688, 1710, and 1778 (Espinoza Soriano 1978a: 331-341). It was only removed upon Peruvian Independence in 1824-25, three decades before Indian tribute 
was officially abolished in 1854 (Espinoza Soriano 1978a: 342). However, this case is the exception rather than the rule. Elsewhere, Espinoza Soriano says that Cañar in Lambayeque, Cajamarca, Huamacucho, Jauja, Tarma, Yaro, and Copacabana (Bolivia) were not so fortunate as to receive exemption from tribute in labour and kind (1978b: 353).

In the Spanish colonial period, each Cañar population was associated with a specific locality and treated separately from one another. The only thing that these disparate Cañar groups had in common was an administratively useful proto-ethnic marker they had inherited from the Incas. There is no reason to think that Cañar in northern Peru had any contact with other groups also identified as Cañar during the colonial or early Republican periods. It is likely that the proto-ethnic marker "Cañar" persisted in the highlands of Lambayeque during this time because it functioned to identify a specific tributary population (see Hirschkind 1995: 313). It would be inadequate to interpret this persistence as a sign of uninterrupted kinship or cultural continuity.

\section{The colonial era}

In the mid-sixteenth century, the tributary population of the highlands of Lambayeque fell under the jurisdiction of a Spanish overlord appointed by Francisco Pizarro, possibly one named Juan Cortés (see see Huertas Vallejos 1991: 497). Such “entrusteeships" (encomiendas) were an early, and relatively brief, form of colonial administration. The Spanish Crown granted an overlord (encomendero) control over the labour of the indigenous population residing in "his" territory, and entrusted him with 
protecting and Christianizing "his” Indians (see Gose 2008: 43-45; Ramírez 1987: 593).

Local lords (curacas) mediated relations between the ecomendero and his subjects, collecting Indian tribute for the Spanish (see Ramírez 1987).

The Crown dismantled the encomienda system in the late sixteenth century, but continued to collect tribute through the mediation of local lords and the forced resettlement of Indian subjects into consolidated communities (reducción). According to Huertas Vallejos, the town of Cañaris was established as a reducción under the reforms of Viceroy Francisco de Toledo in the 1570s (1996: 94-95; see also see also Cook 1982: 78, 116; Gose 2008: 118-123; Huertas Vallejos 1987: 24). The communities of Cañaris and Penachí are recorded as annexes of the reducción of Salas (see Huertas Vallejos 1991: 498, 1996: 97n5; refer to Figure 2). The distance between these three communities is significant. It would take at least three days to walk from the present-day town of Kañaris to Penachí over the forested mountains, and then at least as long to walk from Penachí to Salas in the Motupe River valley. Under this system, people living in reducciones were obligated to provide tribute in agricultural products and cloth, pay a ten percent tax to the Crown on all harvests, make contributions to the Church, and participate in rotations of assigned labour (see Huertas Vallejos 1996: 98).

In the seventeenth century, tribute was likely collected in Cañaris by a local leader or lord (cacique). Colonial land titles from the early 1600s identify doña Juana María Callaypoma as the cacica of Cañaris, and daughter of don Sebastián Callaypoma, who was cacique of Penachí (Alva Mariñas 2008: 264; Sevilla Exebio 1998: 482-483). A well-documented 1654 water litigation case suggests that the Callaypoma's local lordship was one of several in the region. Court documents state that a "Huambo" lord controlled 
the river water above Jayanca, and therefore distributed water vital to the Motupe valley (see Castañeda Murga n.d.; Gómez Cumpa \& Amaya Cueva 1998: 326-330; Peralta Ruiz 1998: 162-163; Sevilla Exebio 1998: 483-484).

It is possible the connection between Cañaris, Penachí, and other towns in the highlands of Lambayeque may have extended beyond administrative convenience and geographical proximity during the Spanish colonial period. They could have a longer history of social, political, and economic association based on the relationships between pre-Columbian descent groups and local lordships formed after Incan subjugation. The control of river water is key to tracing this. Under the Incas, various coastal groups had to give tribute to highland groups that controlled specific river systems. For example, the lords of Penachí would not open their irrigation canals until coastal lords paid them with salt, hot peppers, and cotton (later cloth) (Gómez Cumpa \& Amaya Cueva 1998: 321, 324, 327; Ramírez 1987: 581ff; Sevilla Exebio 1998: 483-484, 488; Vreeland 1993: 182; see also Castañeda Murga n.d.). Such relations of water tribute between the coast and the highlands were still important to local lordships when the Spanish arrived (see Ramírez 1987: 581-583).

The power of the local lords declined in the eighteenth century (see Gose 2008: 277-278), and much of Lambayeque apparently came under the dominion of non-local landowners. By the mid-eighteenth century, parts of the indigenous populations in the highlands of Lambayeque were obligated to work on large-scale estates (haciendas). In the 1740s, some tributary subjects from Cañaris and Penachí broke off to establish a new community called Incahuasi (see Huertas Vallejos 1996). This hamlet was located on the eastern side of the La Leche River opposite Penachí, in between the haciendas of 
Canchachalá, Janque, and Sangana (Huertas Vallejos 1996: 94, 97, 117). These are names of towns in the present-day district of Incahuasi (refer to Figure 2). There is clear indication about the origin of Incahuasi because the nearby estate owners (hacendados) filed grievances about its founding. Huertas Vallejos provides a transcription of part of the court document, dated 1748-88 (1996: 117-118). Incahuasi was first established as a hermitage in 1746 "without express royal license," and a chapel was built the following year with the help of a priest (Huertas Vallejos 1996: 117-118). The large-scale landowners argued the new church was not justifiable, since there was already a viceparish in the hacienda of Janque, where Catholic sacraments could be administered and burials performed (Huertas Vallejos 1996: 118). Nevertheless, some people from Cañaris and Penachí came to live there, possibly to avoid taxation and labour obligations on the haciendas. One can imagine this was the real reason hacendados were outraged about the founding of Incahuasi, as they lost valuable workers.

In the 1780s, the Spanish conducted a population census in northern Peru (see Huertas Vallejos 1996: 101-104). The bishop of the Diocese of Trujillo, Jaime Baltazar Martínez de Compañón y Bujanda, established the parish of Cañaris as independent from Penachí (Vreeland 1993: 182-183). ${ }^{3}$ However, it is unlikely that he visited the town or ordered a church to be built there (Ibid.). I was not able to access the archives for the parish of Cañaris, but I was able to inspect the three old bells in the church's tower. One bears the inscription "I am don Miguel de León y Ribera's," and another has a partially

\footnotetext{
${ }^{3}$ Martínez de Compañón also left other documents of interest, including watercolour sketches depicting people in the highlands of Lambayeque, and a map of the province of Piura that includes present-day Lambayeque. Another important eighteenth century source for this area is Justo Modesto Rubiños y Andrade (see Castañeda Murga \& Espinoza Córdova 2011; Gómez Cumpa \& Amaya Cueva 1998; Huertas Vallejos 1991; Sevilla Exebio 1998).
} 
legible inscription of the year $1721 .{ }^{4}$ The bells may have originated in the hacienda of don Miguel de León y Ribera (Castañeda Murga \& Espinoza Córdova 2011: 177). I do not know when the first church was constructed in the town, but sometime in the eighteenth century seems likely. The church itself was completely rebuilt in the 1960s.

The early Republican era

I have not found any references to the parish or population of Cañaris in secondary sources for the nineteenth century or early Republican period. My overall impression is that this area was difficult to reach, sparsely populated, and without a high concentration of natural resources that were immediately profitable to the Spanish Crown or private estate owners (e.g. plentiful mines or rich agricultural land). Dedicated archival research would be necessary to determine what parts of the area were subsumed under haciendas. To the best of my present knowledge, hacendados controlled much of the highlands in this region in the nineteenth century. This includes areas at the headwaters of the La Leche River (e.g. Canchachalá, Janque, Sangana - haciendas mentioned close to Incahuasi); areas accessible to the Motupe River valley (e.g. Penachí, Salas, the western half of the present-day district of Kañaris); the valley on the north-eastern side of the Huancabamba River (in the present-day region of Cajamarca); and the Chotano River valley in the region of Cajamarca to the east (refer to Figure 2).

According to local oral history, the people within and immediately around the town were never dominated by an hacendado. At least as far back as the time of their grandparents and great-grandparents, they farmed their own lands. Given my present

\footnotetext{
4 “SOY D[E] MYGEL D[E] LEON Y RIBERA”; “ERA EL ANO D[E] 1721 D[E]...”
} 
information, I suspect people in Cañaris were left relatively unmolested by the feudal-like conditions of exploitation on the haciendas that characterized much of Andean Peru up until the mid-twentieth century. It is possible that people from Cañaris were drawn to voluntarily work on costal plantations (see Gonzales 1980), or into migratory labour on the eastern side of the Andes. However, the major trading routes to the eastern lowlands in the eighteenth and nineteenth centuries ran from Piura through Huancabamba to Chachapoyas (Reyes Flores 1999: 71), thereby circumventing Cañaris (refer to Figure 1).

In the early twentieth century, hacendados on the northern side of the Huancabamba River began to appropriate land on the Kañarense side of the river. Community members considered this their traditional land, and they petitioned the Peruvian government to recognize their inalienable territorial rights (see Alva Mariñas 2008). They were ultimately successful, and in 1958 the government recognized the eastern half of the district of Kañaris as first an "indigenous community," and later "peasant community," a legal category that acknowledges and protects community members' collective land title.

\section{Kañaris today}

The only two contemporary communities that have retained the proto-ethnic marker of "Cañar" are located in places that are also called by this name: the province of Cañar in southern Ecuador, and the district and town of Kañaris in northern Peru. That is not to say that these people are the direct descendants of pre-Columbian socio-political groups. Undoubtedly, many people have moved to and from these places over the past five centuries (see Hirschkind 1995 for the case in southern Ecuador). Some newcomers 
became members of the community, while others retained distinct identities as having originated in another place or aligned with another social group. Other people who were related to the wider community through birth and marriage chose to distance themselves from the "indigenous" marker. Yet enough people continued to call themselves "Kañarenses" that there is a distinct cultural and ethnic group called by this name in the highlands of Lambayeque today.

On the other hand, tributary groups once recorded as "Cañar" outside of southern Ecuador and northern Peru abandoned this name to mark their self-identity and community membership. In the colonial era, many tributary subjects left their natal communities because of onerous labour obligations (see Gose 2008: 136-137, 191; Ramírez 1987: 602). People could physically move away from the place, and take on a new social identity to mark their changeable racial, ethnic, and class position. People could also symbolically reposition themselves as not "Cañar" by adopting different forms of work, residence, religion, language, and dress (for contemporary examples in other communities, see Paerregaard 1997; Seligmann 2004). At certain historical and personal moments it could be politically and economically advantageous to position oneself as a member of a distinct subgroup with certain privileges or rights (recall Huertas Vallejos' example of the Cañar of Chiara). Other times, it could be more expedient or desirable to become a mestizo, a person of mixed ancestry - and thereby be exempt from tribute in labour and kind (see Harris 1995: 354) - with the potential of moving into the hierarchically superior category of "whites" over time.

Similarly, just because some people call themselves "Kañarense" today does not mean their descendants will identify as members of this distinct group in years to come. 
Ethnic identification is not fixed or unchanging. Furthermore, while I observed people in Kañaris making strong distinctions between their community and "foreigners" who reside in their town, this does not rule out the possibility that community membership could expand to include the descendants of these people in the future. In the following chapters, we will continue to explore how people reckon membership in the community of Kañaris, and why "being Kañarense" matters to people today.

\section{Why sorcery?}

When I travelled to Kañaris with Mercedes, we met one of her neighbours during our stop in the valley town of Pucará. At first, he told her that he was going to consult a curioso to heal a sick family member. Mercedes interpreted this according to the local convention of referring to sorcerers indirectly, and because she knew this was the intended subject of my research, she asked if we could accompany him. The man then said he was not going to a brujo, a sorcerer, and that moreover, he does not even believe in sorcery. Both Mercedes and I understood this to mean he actually was going to visit a ritual specialist who practices the genre of healing locals call brujería, or sorcery. I was not surprised when I saw this same man consult a sorcerer months later.

Why is this event significant? It illustrates how in Kañaris, people avoid talking about sorcery directly, and publically deny that they consult sorcerers - even if their intention is to cure an illness rather than do malicious witchcraft. Yet people $d o$ visit this type of specialist when no other medical treatment seems to work, regardless of their stated "belief." 
Sorcery is not a topic of polite conversation. Even in the confidences people shared with me in the privacy of their homes, my interlocutors emphasized the sorcerer's morally upright role of treating illness, and sorcery as a type of healing. For example, someone can say, "Only a little sorcerer can heal ...[that type of illness]." By using the diminutive form of "sorcerer" (brujito), a speaker mitigates the negative connotations of sorcery. By framing sorcery as healing rather than witchcraft, people draw attention away from its morally transgressive side - and by extension, exempt themselves of the suspicion of having visited a sorcerer in order to harm someone.

People in Kañaris also distance themselves from sorcery as witchcraft because they do not want others to think they are "superstitious Indians." For example, a nurse at the local medical post told me, relatively few people come to be treated because they are "superstitious" and go to sorcerers instead of medical doctors. Locals know that visitors see them as "poor and backward." They are proud of being members of the peasant community, and they think of themselves as culturally distinct from visitors and resident foreigners, but they also value their Peruvian citizenship, the education of their children, and their intentional efforts to improve or "advance" their lives.

The nurse's comment fails to understand that sorcery or "brujería" has a specific place in the local medical system and Kañarense ideas of illness and healing. In Kañaris, multiple medical epistemologies exist side by side. People access specialists with distinct therapeutic methods because only they can address specific causal factors. As the severity of the illness increases, so does the specialization. For minor conditions, a person can choose among several options according to his or her monetary resources and personal preferences. For example, home remedies and over-the-counter pharmaceuticals can treat 
everyday ills such as headaches, coughs, and stomach upset. If the condition persists or worsens, a person can visit a local specialist who does "cleansing with guinea pig" to receive a more complex herbal remedy, or the medical post for a pharmaceutical injection or pill. But sudden, acute, and life-threatening illness must be treated by a more advanced specialist who can respond to the specific cause of the condition. Only medical doctors can treat cancer or perform surgery, and people will travel to Chiclayo or another city if necessary. On the other hand, only sorcerers can cure illness attributed to the place-based spirits called encantos. As one person told me, "Doctors don't know, they can't see; they can't do anything" to treat this type of illness.

The Kañarense medical system is organized according to a local logic. It offers people multiple curative options for minor illnesses, and advanced specialists for more serious conditions. From an analytical perspective, the most important distinction is between illnesses attributed to "naturalistic" and "personalistic" factors. "Naturalistic" illness due to environmental elements without a conscious agent can be treated by a variety of methods, while "personalistic" conditions arise from an agential entity's intention to harm the victim (see Foster 1976: 775). In Kañaris, "personalistic" agents include evil spirits (malos espiritus) who "grab" a victim's soul, and the encantos whose power contaminates and curses. Medical doctors do not acknowledge these causative agents, and they do not recognize conditions such as soul loss, chronic social conflict, bad luck, or seemingly "naturalistic" diseases caused by witchcraft, and so they can do nothing to help the victim.

From the patient's perspective, what is most important in determining the appropriate curative treatment is what they are comfortable with and what "works." A 
visit to a hospital and a sorcerer both require a significant investment of time and money. Therefore, people will first try the other forms of curative treatment available, either at the same time or in sequence, from home remedies and over-the-counter pharmaceuticals, to "cleansing with guinea pig" and the local medical post. If none of these treatments work and the symptoms persist, or if a herbalist, diviner, or medical doctor diagnoses a more serious illness, the person will consider going to a more advanced specialist.

The stories people told me of their own illness experiences indicate that even if a person thinks that sorcerers are frauds and sorcery is superstition, if they or a close family member is deathly ill, they will try every curative treatment available to them. Thus people who say they do not "believe" in sorcery will still hedge their chances, and reevaluate their understanding when they experience devastating failure. In my experience, people in Kañaris are pragmatic. In the end, it does not matter what one "believes," as long as the treatment "works" to cure the illness. This is indicated when the patient's symptoms cease, and their normal corporeal, productive, and social well-being is restored.

The Kañarense practice of sorcery as a genre of healing has to do with experiential efficacy, not stated belief. Since I am an anthropologist, I am not interested in determining how this healing is effective according to a Western epistemology. What is interesting is that people say it makes a difference to them, and continue to do it, and that the local practice and discourse of sorcery points to things that matter to people in Kañaris. As both healing and witchcraft, sorcery provides an entry point to understand Kañarense society - how people experience suffering and strive to achieve the good life, 
what behaviours and actions they evaluate as commendable or despicable, and why it is significant that this practice both helps and troubles them.

\section{Sorcery and witcheraft}

In Kañaris, the blanket term brujería refers to both healing and harming with the power of the encantos. For the sake of clarity, I make a lexical distinction between "sorcery" (brujeria) and "witchcraft." My interlocutors regularly highlighted the morally commendable intention of both practitioners and clients to cure illness and restore wellbeing, and downplayed their correlative potential to curse and harm. I identify this encompassing ritual practice as brujería as this is the term people in Kañaris use. I consistently failed to communicate my research interests with locals when I used the term curanderismo (“[ritual] curing"). People generally only understood my research topic when I mentioned brujeria, which locals sometimes genteely glossed as "traditional medicine."

Like two sides of the same coin, the illness and healing of brujeria are mutually constituted (see also Glass-Coffin 1998: 18). They are activated and enabled by the same supernatural power, by the same ritual specialist, and through very similar ritual techniques. I use the term "witchcraft" to refer to the malevolent mode of brujería. It is the morally deplorable practice of using the power of the encantos to intentionally harm someone, causing acute and sudden illness, crop and animal loss, business failure, serious social conflict, and general "bad luck." 
In Kañaris, a person who practices brujería is a maestro ("master") or brujito ("little sorcerer"). In local usage, the Spanish term maestro is respectful and deferential. A master is someone who has specialized knowledge, and is an expert in his or her field. A master is an authority figure from whom one can learn, and whom one should respect. On the other hand, a brujito is someone who practices brujeria. The more proper Spanish term for someone who practices sorcery is brujo ("sorcerer"). Locals have added a diminutive Spanish suffix to the noun (-ito) to subtly shift "sorcerer" to "little sorcerer."

In Spanish, the diminutization of nouns and proper names serves several purposes, including making things and people small and endearing. This euphemistic turn of phrase follows the local logic of qualifying something as "little" to lessen its impact. With brujito, the diminutization of "sorcerer" functions to soften the negative connotations of brujeria and neutralize the potentially nefarious practices of the brujo. He is, after all, only a "little sorcerer." A brujo is wicked; a brujito is merely mischievous. For the sake of clarity, I use the term maestro to identify a practitioner who is using brujería to heal, and brujo when a practitioner is using this same practice to harm.

The lexical distinctions between maestros and brujos, and brujeria and witchcraft, are not just anthropological minutiae. They emphasize the fact that maestros always have the ability to both cause and cure illness. By virtue of his innate ability, learned technique, and divinely bestowed gift for shamanic visioning, the maestro directs the power of the encantos towards specific people so as to effect illness or well-being. He does this only when a client pays him to undertake a healing or cursing mesa ritual. Community members say that people go to unscrupulous brujos to do witchcraft because they envy and want to hurt a neighbour, work partner, or extended family member. While 
no one I talked to admitted they had consulted a brujo, several people confided in me that they strongly suspected that they or a close family member had been the victim of witchcraft. Brujeria as witchcraft is at the extreme end of a range of indirect and direct expressions of conflict in Kañarense society that includes gossip, an unwillingness to extend reciprocal aid or goodwill, theft, and bodily harm. While these are not all everyday occurrences, witchcraft presents a moral problem for community members, since it involves the intentional action of one person to seriously harm another. This results in illness symptoms that can only be cured by visiting a healing maestro.

\section{Sorcery in regional context}

In Kañaris, sorcery addresses conditions of bodily illness and embodied ill-being that do not respond to other forms of treatment: Neither what locals call "traditional medicine," such as herbalism and "cleansing with guinea pig," nor Western medicine, represented by the local medical post and regional hospitals. The sorcerer calls on the encantos, and directs the supernatural power of these place-based spirits so as to bring about either illness in a victim or healing in a client. During a ritual event called the mesa ("table" or "mass"; see Chapter 8), the sorcerer draws upon an established repertoire of ritual acts, such as refreshing, raising, extracting, dispatching, sucking, rubbing, visioning, and flowering.

In his morally upright and discursively foregrounded role as a ritual healer, the sorcerer employs a rhetoric of curing through the extraction of the invisible substance that is the power of the encantos. He extracts this illness-causing power through sacred objects - primarily rocks, swords, and staffs - that function as mediating conduits to the 
encantos. He then sends the invisible substance back to the specific encantos where it originated. The sorcerer also uses the power of the encantos to cleanse and "uplift" the client, thereby restoring his or her health, productivity, good luck, and general wellbeing. (For this four-fold performative framework of ritual healing as genre, event, act, and rhetoric, see Csordas 1994: 59, 1996: 94.)

In this section, I situate the practice of Kañarense sorcery (brujería) in a wider area that spans the northern highlands, the northern coast, and the western edge of the Amazonian jungle. The practice and underlying logic of brujería partially overlaps with practices in these adjacent regions. In addition, the ritual praxis of the northern Peruvian Andes resonates in significant ways with that of the southern highlands. I untangle these threads by briefly describing each region in terms of ritual healing, the underlying logic of the practice's efficacy, the motivation of participants, and the performative idiom through which the practice is framed. My goal is to demonstrate that brujeria in Kañaris is not a static system closed off from the rest of the world (see Greene 1998: 643). This lays some of the foundation for an ethnographic understanding of people in Kañaris as agential subjects who reach out to wider regional and national contexts even as they are grounded in distinctly local concerns, a theme which we will continue to explore in later chapters.

The highlands and the coast

One of the most emblematic aspects of brujería is the ingestion of the mescalinerich cactus called San Pedro (Trichocerus pachanoi or Echinopsis pachanoi). There is archaeological evidence that San Pedro was ritually used in pre-Incan kingdoms on the 
northern coast: the Chavín (1300 - 600 BCE), Moche (200 - 850 CE), and Chimor (900 1470 CE) (see Burger 2008: 687; Castillo Butters \& Uceda Castillo 2008: 708; GlassCoffin 2010; Joralemon \& Sharon 1993: 185; Moore \& Mackey 2008: 783; Polia 1996: 289-293; Pozorski \& Pozorski 2008: 625; Sharon 1978: 40-42). There is also extensive archival evidence of brujería in northern Peru during the Spanish colonial period (see Glass-Coffin 2010; Larco 2008; Millones 2002; Polia \& Chávez Hualpa 1994). The antecedents and emergence of contemporary brujería warrants its own study. For our present purposes, the important thing to know is that the northern highlands and coast have long been an area of intercultural exchange.

Today, these two northern Peruvian regions are famous for brujeria. In coastal cities such as Trujillo, Chiclayo, and Piura (refer to Figure 1), "curanderos" (healers) perform mesas to cure clients of illnesses attributed to malicious sorcery - that is, witchcraft. As in Kañaris, coastal curanderos "vision" with San Pedro, "raise" tobacco, extract illness by "rubbing” the client's body with swords and staffs, and blow floral waters to "refresh" their ritual tables (see Glass-Coffin 1998: 18-27; Joralemon \& Sharon 1993: 4, 8-9; Sharon 1978: 170-174). In performative terms, the brujeria practiced throughout northern Peru is one and the same. However, the motivations of clients, and the understanding of the practitioner's efficacy, are significantly different for people in the highlands and on the coast.

Ethnographers emphasize that coastal curanderos primarily cure illnesses attributed to witchcraft (see Glass-Coffin 1998: 4-5; Joralemon \& Sharon 1993: 4, 196198; Sharon 1978: 30-32). People in Kañaris recognize coastal practitioners as legitimate healers, and several people told me they had visited a sorcerer in Chiclayo to be cured of 
a chronic illness. However, ethnographers do not say that coastal clients go to curanderos to increase their production, luck, or well-being - which is an important aspect of brujería in Kañaris.

Anthropologist Bonnie Glass-Coffin also suggests that curanderos on the coast associate illness with "sin," and curing with "being close to God" (1998: 158, 161, ch. 3 passim). This is not simply a matter of ritual specialists aligning their practice with Catholicism. The marked presence of sin and God among coastal practitioners point to a constellation of concerns that is distinct from those of subsistence peasants in the northern highlands.

Curanderos in coastal cities call on the power of the encantos to heal illnesses attributed to witchcraft, and on the surface, this appears to be the same thing that happens in the highlands. On the coast, however, these place-based spirits are not the ultimate sources of health and well-being. Rather, coastal practitioners point to the Christian God as the true source of life and ritual efficacy (see Glass-Coffin 1998; Joralemon \& Sharon 1993). The encantos are more like "free-flowing forces of nature" (Joralemon \& Sharon 1993: 150), and the curandero directs their latent supernatural power according to his (or her) God-given ability.

On the coast, sorcery (brujería, curanderismo) is discursively and performatively framed as a "battle" to "balance" the forces of good and evil (see Glass-Coffin 1998: 150-151; Joralemon \& Sharon 1993: 166-167; Sharon 1978: 138-140). Anthropologist Douglas Sharon presents this as a structural dialectic, illustrated by how the ritual table is laid out according to a series of opposites: good/evil, right/left, up/down, night/day, and death/rebirth (Joralemon \& Sharon 1993: 165-176; Sharon 1978: 62-71, 101-111). While 
coastal curanderos use their sacred swords and staffs to "extract" illness, ethnographers emphasize these objects are also used in the "battle" the practitioner engages in on behalf of the client.

In contrast, brujería in Kañaris is centred on the extraction of the illness-causing substance from the client's body, and sending it back to its origin in the encantos. Practitioners can battle "evil" sorcerers, but this is not emphasized in what people say and do. Neither sorcerers nor their clients suggest that God makes this possible; the encantos are the most important and immediate divine powers. Their supernatural power is manifested in a person's bodily condition, material extensions of the person (such as their crops and animals), and in their social extensions (such as relations with fellow community members). A brujo or "master" (maestro) is able to bless and heal - or curse and sicken - not because the encantos or their power is "good" or "evil," but because he directs their power with the intention to harm or heal.

The highland importance of the encantos is not limited to Kañaris. The northern Andean region most famous for brujeria is the town of Huancabamba and a nearby series of high-altitude lakes called Las Huaringas (see Camino 1992: 113-117; Giese 1991; Polia 1996: 91; Sharon 1978: 123-127; refer to Figure 2). They are situated at approximately 3600 metres above sea level, close to the Ecuadorian border (see Arroyo Aguilar 2004: 103). For at least the past thirty years, Huancabamba and Las Huaringas have attracted sorcerers and clients primarily from Peru and Ecuador. The region also increasingly attracts foreign tourists and travellers. Huancabamba is second only to Iquitos in the burgeoning Peruvian market of "shamanic tourism" (see Fotiou 2012; Santos-Granero 2002: 561-564). 
The lakes of Las Huaringas are renowned for their healing and cleansing waters. Several ethnographers note the fame of the area (see Camino 1992: 115-119; GlassCoffin 1998: 22-23, 77; Joralemon \& Sharon 1993: 31, 54, 114, 159; Polia 1996: 114, 174, 188-189, 197-199; Sharon 1978: 123ff). The lakes are powerful encantos and are regularly invoked in curing songs in Kañaris. Sorcerers have ritual pacts with specific lakes and make personal pilgrimages to them, for example to be initiated or to collect medicinal plants. Their sacred water is powerful, and this is a strategic "selling point." For example, I have found bottles of water for sale in the "sorcery market" in Chiclayo advertised as coming from Las Huaringas. The most recognizable aspect of brujeria in Huancabamba is that sorcerers regularly bring groups of up to twenty people to specific lakes for cleansing baths.

In the northern highlands, people consult sorcerers to cure sorcery illness, and to increase their luck and production. These are immediate concerns for a subsistence farmer whose family will not eat if his or her crops fail. It also points to a cultural logic that is distinctly "Andean." While urban workers are also in precarious subsistence positions, unless an individual is a first generation migrant from the highlands (see Sax 2011: 108-111), he or she is unlikely look to place-based spirits to help their situation. Throughout the Andes, people address place-based spirits for agricultural productivity and fertility. As we will see below, their involvement in agricultural activities varies throughout the Andes. Nevertheless, the taken-for-granted understanding of place-based spirits as repositories for a power that has the potential to bring life and well-being is a theme that continues to be played out in the northern Peruvian highlands. 


\section{The highlands and the jungle}

Kañaris is situated in between the coast and the jungle. It is administratively tied to the regional capital of Chiclayo on the coast, but the town is geographically closer to the eastern side of the Andean mountains that descend into the Amazon rainforest. For example, it takes twice as long to travel to Chiclayo as it does to reach Jaén (refer to Figure 1). This city is a gateway to western Amazonia and other cities along the Marañón and Utcumbamba Rivers, such as Bagua, Moyobamba, and Tarapoto (refer to Figure 1). Peruvians call this region where the mountains meet the rainforest the "eyebrow of the jungle.” Kañarenses travel to Jaén for work and city errands. Many people have family members in Jaén and other towns in the area that descends into the jungle. For example, Andrés has a cousin in Tarapoto and once had land there with coffee trees. Men from Kañaris often travel to this area to work on coffee plantations. People are aware that there are powerful sorcerers and shamans in the Amazon. While no one told me they consult Amazonian shamans, I know a sorcerer from Kañaris who travelled to Jaén to attend to his clients there.

Although the northern highland's historical connections with the jungle are less clear than those with the coast, I suspect that there has been - and continues to be significant interchange between the regions (for archaeological evidence, see Guffroy 2008). Therefore, I am not surprised to find performative similarities in ritual healing in

the northern highlands and western Amazonia. For example, shamans in this Amazonian region also sing curing songs, shake rattles, blow floral waters, consume tobacco, and suck illness out of the client's body. These "Amazonian" ritual markers are completely absent in the Andes of southern Peru and Bolivia. 
Anthropologist Peter Gow hypothesizes that there is a common shamanic practice throughout the eastern lowlands of Peru and Ecuador, and specifically among all the people "who were linked into the economy of rubber in western Amazonia" (Gow 1994: 93, 110). ${ }^{5}$ While it is difficult to generalize among diverse Amazonian groups, Gow's speculative argument is helpful to compare brujería in Kañaris with the "single tradition of shamanic curing [that] is shared by the culturally heterogeneous peoples of western Amazonia" (1994: 97) for two reasons. First, he discusses the systematic relations among ritual healing, economy, class, and race throughout a wide area that includes the eastern lowlands immediately adjacent to Kañaris (see Gow 1994: 92-93). Second, he provides an example of an analysis of ritual healing that is rooted in the local concerns of contemporary Amazonian peoples, and not an "unbroken" indigenous tradition (see Gow 1994: 90-91).

Shamans throughout western Amazonia ingest a psychotropic plant called "ayahuasca" or the "vine of the dead" (Banisteriopsis caapi) to diagnose and cure clients of sorcery illness (Gow 1994: 93; Harner 1972: 153). (For a botanical description of ayahuasca and other plants used by shamans in western Amazonia, see Bennett 1992.) According to Gow, a key characteristic of "ayahuasca shamanism" in this region is the use of this plant to specifically and exclusively cure illness (1994: 93-94). Shamans in other Amazonian regions either use ayahuasca in contexts other than ritual healing, or do not use ayahuasca at all (Gow 1994: 110). Moreover, shamans in western Amazonia only cause or cure sorcery illness; they cannot bestow luck or curse a rival (Gow 1994: 102103). "In this sense," Gow says, "the powers of the ayahuasca shaman are the powers of

\footnotetext{
5 "For the purposes of this chapter, I define western Amazonia as the whole rain forest area drained by tributaries of the Amazon above the mouth of the Javarí [River], that is, most of the eastern lowlands of Peru and Ecuador." (Gow 1994: 93)
} 
the forest, and he can only give the patient the gift of the forest, which is life or death" (1994: 103).

Ayahuasca shamans address forest and river spirits, who help them locate and extract illness-causing sorcery objects from the client's body. Shamans can cure illnesses caused by the retribution of natural objects or the malice of demons, but usually only children suffer from these conditions (Gow 1994: 94). For adults, ayahuasca shamans primarily cure illness attributed to sorcery (Gow 1994: 94; see also Brown 1986: 60-65; Descola 1996: 112-113; Harner 1972: 152; Santos-Granero 1991: 98-102; Whitten 1976: 145-148).

During an all-night ritual session, the shaman and his clients orally consume the prepared ayahuasca vine, which he has boiled in water for several hours (see Descola 1996: 205; Harner 1972: 153; Whitten 1976: 153-154). The shaman may also consume other plants, such as tobacco, "toé," and "datura" (Brugmansia suaveolens; Datura arborea) - which are also used by sorcerers in Kañaris (Brown 1986: 58-59; Gow 1994: 95; Harner 1972: 153, 160, 164; Whitten 1976: 153, 158). He takes ayahuasca to "see" the essence of the illness and extract it from the client's body, which is mediated through a material object such as a dart, thorn, or animal tooth (Brown 1986: 60-62; Descola 1996: 316, 331-333; Gow 1994: 93; Harner 1972: 154-157, 160-163; Whitten 1976: 154159). To facilitate his visioning and healing, the shaman shakes a fan of leaves, blows tobacco smoke over the client's body, whistles, and sings sacred curing songs (Brown 1986: 62; Descola 1996: 317-322; Gow 1994: 95; Harner 1972: 161-162; Whitten 1976: 157). The shaman is able to suck the illness-causing sorcery object out of the client's body because of a magical phlegm or saliva-like substance in his stomach, which was 
given to him by the shaman under whom he apprenticed (Brown 1986: 60-61; Descola 1996: 336-338; Gow 1994: 93; Harner 1972: 155; Whitten 1976: 146-147).

In order to cure, the shaman needs the "help" of the forest and river spirits. These spirits are "the primary sources of disease and curing power," but they are not "good" or “evil" (Gow 1994: 94-95). The "mother" spirits are the creators of the forest and river, and the "owner" spirits are the guardians of those domains (Gow 1994: 94). The mother spirits take the form of giant anacondas, and the owner spirits usually appear as white men (Ibid.). These spirits "abhor" and avoid humans, and so the shaman "seduces," "tames," and "calms" them with his curing songs (Gow 1994: 95). He is able to accomplish this with the aid of his personal helper spirits, and the spirits of the psychotropic plants he ingests (Ibid.). By consuming ayahuasca, the shaman "becomes partly a spirit," and the mother and owner spirits of the river and forest reveal themselves to him (Ibid.).

Gow's discussion is primarily based on his experience among the Piro and Asháninka (Campa) people of the Lower Urumbamba River (1994: 96), but he intends it to provide a basic outline of shamanic curing practices throughout western Amazonia. By Gow's definition, “ayahuasca shamanism” is well documented among Jívaroan peoples (Achuar, Aguaruna, Shuar) and the Canelos (Quichua) in the Amazonian regions of eastern Peru and Ecuador (see Brown 1986; Descola 1996; Harner 1972; Whitten 1976; but compare Santos-Granero 1991: 117-120). Ethnographers have also described this genre of ritual healing in the city of Iquitos (see Dobkin de Rios 1972).

Gow's exposition is more complex than I have room to discuss here. For our present purposes, it is sufficient to know he argues that contemporary ayahuasca 
shamanism can be traced to specific sites of cultural interaction among whites, mestizos, and Indians in western Amazonia over the past three hundred years. The practice of ayahuasca shamanism originated in these sites - the semi-peripheral locations of Christianized Indians, rubber workers, and mestizos (see Gow 1994: 105-110). Through apprenticeship to powerful shamans in cities such as Iquitos and Pucallpa, Indians bring this healing knowledge back to their forest communities (Gow 1994: 96-97). The shaman then "tames" and "seduces" the mother and owner spirits to convince them to "help" him cure his client's illness (Gow 1994: 103). Gow further suggests the idiom of "help" makes sense to people because that is how Indians and mestizos survive in the subsistence economy (1994: 103-104). Shamans demand payment upfront, but if a client is unable to pay in cash, he will accept life-long "help" instead (Ibid.). This mutual extension of help benefits both the shaman and the client. As Gow says, "Given life by the shaman, the patient is drawn into his personal network of 'helping' kin" (1994: 104).

Both ayahuasca shamanism and brujería are focused on extracting illness-causing substances from the client's body with the help of supreme spirits. But while ritual healing in western Amazonia is performatively and discursively positioned within "seduction" and "help," the ritual praxis of Kañaris resonates more with the idioms of "sacrifice" and "payment" typical of the southern Andes.

The northern and southern highlands

Although Kañaris is geographically distant from the Andean cultural area of southern Peru and Bolivia, the underlying logic of their ritual practices have something in common. This is the notion that spirits embodied in mountains and other prominent 
landforms are repositories for a supernatural power. This power can be used to cure illness, and to do and undo witchcraft. Furthermore, this power can also be used to increase one's luck and production. This is a function of ritual healing that ethnographers do not emphasize in coastal sorcery and western Amazonian shamanism. In Kañaris, the encantos can "cleanse" a client's luck and thereby "advance" his or her productive activities. In the southern Andes, addressing place-based spirits is an integral part of agricultural production.

For the purposes of this dissertation, I define the southern Andes as the highland region south of the Jequetepeque River valley, near the city of Cajamarca. I use this as a conceptual boundary because different ritual substances characterize the areas south and north of this area. According to Peruvian anthropologist Juan Javier Rivera Andía, the point at which Andean peoples begin using San Pedro instead of coca leaves is close to where the borders of the regions of Lambayeque, La Libertad, and Cajamarca meet (personal communication, January 2014). This is north of the city of Cajamarca, close to the Jequetepeque River. Kañaris is situated further north of this river valley.

I realize the Andean region of southern Peru and Bolivia is more commonly identified as the Central Andes. I intend my word choice to clearly and succinctly juxtapose the northern and southern Peruvian highlands. While people often think of Cuzco and nearby regions when they refer to the "Andean" cultural area, I intend to demonstrate that, at least in the case of Kañaris, there are also Quechua-speaking people in northern Peru who act according to a distinctly "Andean" understanding of the world. In my experience, this includes a personified and animating landscape, social ties forged 
and maintained through generalized reciprocity, and the common legacy of the Incan empire and Spanish colonialism.

In the highlands of southern Peru and Bolivia, householders make ritual offerings, payments, and libations to tutelary divinities. These are the mountain spirits and "earth mother" (pachamama), who ensure the productivity and prosperity of crops and animals. Community members attribute local mountain spirits with individualized names, characteristics, and tendencies, and refer to them with deferential Quechua and Aymara terms such as "lord" (apu), "condor" (mallku), and "hawk" (wamani) (see for example Allen 2002: 26; Bastien 1978: 63; Gose 1994: 212, 293-294n37; Isbell 1978: 59).

Anthropologist Catherine Allen argues that mountain spirits are repositories for a life-giving and vitalizing energy (sami) that fertilizes and animates living things (Allen 2002: 33ff; see also Gose 1994: 126-135, 203). Through water, mountain spirits direct this vital energy to the crops, animals, and people under their care (see Gose 1994: 126135, 217, 2008: 314-319). Through ritual offerings such as coca leaves and corn beer, householders direct this energy back to the mountain spirits, maintaining the "pump" of reciprocity that makes life in the highlands possible (Allen 2002: 73, 107-110; see also Gose 1994: ch. 7 passim).

Mountain spirits are also "hungry," and householders are obligated to "feed" and “pay” them with ritual offerings and libations (see Allen 2002: 127-135; Bastien 1978: 65-67, 75-76, 136, 147; Crandon-Malamud 1991: 124; Gose 1994: 222-224; Fernández Juárez 2004: 134-135; Sax 2011: 83-84, 89-92). People make offerings to them on ritual "tables" (also called mesas, as in Kañaris), and then burn or bury them (for a detailed description, see Gose 1994: 194-224). In the terms of Spanish anthropologist Gerardo 
Fernández Juárez, people make these ritual offerings on a "ceremonial banquet table," with each "plate" carefully constructed according to the tastes and preferences of particular spirits, and the desired goals of householders (Fernández Juárez 1997: 222; see also Gose 1994: 215). Besides coca leaves, offerings include llama chest fat; metal figurines of humans, animals, farm tools, stars, and the sun and moon; hard candies and sweet cookies; coloured wool threads; small squares of shiny gold or silver paper; incense and aromatic resins; and sugar cane alcohol, wine, and beer (see Fernández Juárez 2004: 123-133). A particularly powerful offering is the dried fetus of a llama, alpaca, or other animal (Fernández Juárez 2004: 126, 130; Gose 2004: 215). Once the practitioner has carefully assembled a selection of ceremonial ingredients, he wraps it in paper and burns it so that it can be "tasted" by the mountain spirit (Fernández Juárez 2004: 134).

People make these offerings at key moments in the agricultural year, including field preparation and sowing, harvest, and just after the harvest when there are animal fertility rites (see Allen 2002: 129-143; Bastien 1978: 51-53, 61; Fernández Juárez 2004: 134; Gose 1994: 110-114, 151-152, 156-157, 165-167, 174, 194-195; Isbell 1978: 59, 151-155; Sax 2011: 39-49). People also make ritual offerings to place-based spirits during community-wide rituals, such as canal cleaning, the feast of the community's patron saint, Carnival, All Soul's Day, and other festivals that correspond to the Catholic calendar (see Allen 2002: 139-140, 150-171; Gelles 2000: 75-82; Gose 1994: 101, 141143; Isbell 1978: 138-151). Householders who neglect to make offerings can experience crop failure, animal loss, and the illness and death of family members because of the 
retribution of an angry mountain spirit (see for example Crandon-Malamud 1991: 4-5; Gose 1994: 220, 222).

In the southern Andes, lay people can communicate with mountain spirits through these ritual offerings. In addition, there are ritual specialists who prepare more elaborate offerings during times of illness and exceptional need (see Allen 2002: 135-137; Bastien 1978: 135ff; Gelles 2000: 81-82). These include ritual healers called "paqos" and “yatiris" (see Allen 2002: 23, 111-112; Crandon-Malamud 1991: 128-129; Fernández Juárez 2004: 19-20, 28; Gelles 2000: 82). Ritual healers treat illnesses that medical doctors cannot — those conditions that affect the client's soul and social well-being by making offerings to the mountain spirit or lesser devil that has caused the illness (see Fernández Juárez 2004: 112n105, 113n107, 134). Other, nefarious, specialists called sorcerers or "layqas" make ritual tables to cause illness and misfortune through witchcraft, although this is much less commonly represented in the ethnographic literature than offerings for fertility and healing (see Allen 2000: 23; Fernández Juárez 2004: 40, 50n38; Gelles 2000: 82; Gose 1994: 186).

Regular householders and lay people can address mountain spirits in the southern Andes directly with their own ritual sacrifices. These "consumable" offerings and payments mediate the undomesticated power of the mountain spirits, and direct it towards Andean peoples' desired goals. In the northern Andes, place-based spirits embodied in mountains, waterfalls, and high-altitude lakes are also repositories for a supernatural energy that has the equal potential to help and harm people. However, lay people cannot communicate with these place-based spirits directly, and they do not have individualized relationships of obligation and reciprocity with the encantos. Only the sorcerer can 
communicate with the encantos, and so people must go to him if they want to do witchcraft, cure an illness attributed to their power, or "cleanse" and "uplift" their luck and productive capacities.

\section{Kañaris at the crosscurrents}

Brujería is practiced throughout a large area of northern Peru. This is broadly delineated by the coastal cities of Trujillo, Chiclayo, and Piura; Loja in southern Ecuador; Jaén and Chachapoyas on the eastern slopes of the Andes; and Cajamarca to the south (see Bussmann \& Sharon 2006; Camino 1992: 44, 54-55; Joralemon \& Sharon 1993: 24). While people practice ritual healing (and witchcraft) to the east of the Andean mountains in the "eyebrow of the jungle," and in the southern Andes of Peru and Bolivia, practitioners in those areas do not address encantos or use San Pedro. In western Amazonia, shamans call upon forest and river spirits to help them to extract illness from the client's body with ayahuasca. In the southern Andes, ritual healers feed hungry mountain spirits with offerings that include coca leaves and corn beer.

While these performative differences in ritual healing are notable, the underlying ritual praxis and cosmological understandings are more significant. In the jungle, shamans primarily treat illnesses attributed to witchcraft. Gow emphasizes that shamans and their clients do not seek the help of forest and river spirits to increase production, money, or luck (Gow 1994: 102). According to Gow, production in western Amazonia requires neither sacrifice (as in the southern Andes), nor hunting magic (as with Amazonian peoples in other areas; see Århem 1996; Viveiros de Castro 1998; but compare Brown 1986: 70-96). Ayahuasca shamans only cause or cure witchcraft illness, 
and shamans perpetrate witchcraft themselves by "throwing" unseen sorcery objects (such as darts, thorns, or animal teeth) to enter the victim's body (see Harner 1972: 119, 157).

On the coast, ritual specialists also treat illnesses attributed to witchcraft. While coastal curanderos call upon the supernatural power of the encantos to cure clients of witchcraft illness, the power of God ultimately supersedes that of the encantos. As Douglas Sharon notes, brujería becomes more Christianized as one moves from the highlands to the coast (1978: 35). It is by God's grace that curanderos are able to heal, and through the mesa ritual, lay people encounter God's benevolent power at work in their lives (see Glass-Coffin 1998). Therefore it makes sense for practitioners to frame the healing mesa as a battle to balance the forces of good and evil (see Sharon 1978). In addition, coastal curanderos and their clients do not look to the encantos as a source of a vitalizing or luck-enhancing power that contributes to an individual's productive activities. According to existing ethnographies, clients do not visit curanderos so as to increase their production in either agricultural or market-based activities.

This is a role of place-based spirits that ethnographers present as a distinctly “Andean" cultural understanding. In the highlands of southern Peru and Bolivia, both subsistence peasants and urban migrants regularly make ritual offerings to mountain spirits (for urban contexts, see Sax 2011; Seligmann 2004). These divinities are the ultimate sources of life and death. They are repositories for a supernatural power that circulates from the mountains to the fields, herds, and people under their care. This power is necessary to make crops and animals grow (see Allen 2002; Gose 1994). But the mountain spirits are also hungry, and if they are not fed with ritual payments, they will 
cause illness and misfortune to befall individuals. Thus people in the southern Andes have individual relationships of obligation and reciprocity with tutelary divinities who are embodied in and animate the landscape.

In Kañaris, people do not regularly address the encantos or other place-based spirits so as to make agricultural production possible. However, clients can visit sorcerers to cleanse them of "bad luck," increase their "good luck," and thereby increase their productive capacities. People can also request special mesas that permanently modify their individual abilities, so as to make them into "good workers." In Kañaris, people understand one's productive output to be the result of the work that one puts into it. The mountain spirits do not make the crops grow as in the southern Andes. However, placebased spirits can modify the environmental conditions and bodily dispositions of people, which are directly related to their agricultural output.

In Kañaris, illness attributed to witchcraft is connected to social relations, and one's social relations make agricultural production and the maintenance of a household possible. The state of one's social relations is reflected in the state of one's production, luck, and health. If one is not able to get anything done, if nobody will cooperate with you, if unfavourable weather conditions destroy one's crops, if one's animals disappear or sicken and die, one will suspect that witchcraft is at work. Someone in the community has contracted a sorcerer to curse you and have these misfortunes befall your household. Thus mesas for curing illness are also about checking in with one's social relations. If one does not have good social relations, one will not be successful in the subsistence economy. 
Kañaris is situated at the geographical and cultural crosscurrents of the coast, the jungle, and the highlands. Brujería in Kañaris closely resembles ritual healing in coastal cities, and shares some performative similarities with western Amazonian shamanism. Nevertheless, the underlying understanding of its efficacy, and the motivation of clients, has more in common with the ritual praxis of the Andean area to the south. At the same time, Kañaris is distant from - and historically linked to - the Incan heartland of southern Peru. Today, the majority of people in this community speak Quechua as their first language, participate in the annual cycle of Andeanized Catholic festivals, and support their families on small plots of land. The community is socially reproduced through shared kinship, rural residence, and subsistence livelihoods, and it is politically defined by its legal status as a "peasant community" (comunidad campesina). As we will see in the following chapters, these local concerns are vital to understanding the existence and significance of brujería in Kañaris. 


\section{Chapter 1: The Community of Kañaris}

“Can you show me how to use a computer?” Mercedes' visiting brother asked me. I thought he meant the small laptop I used to write field notes, but I soon found that he was referring to a different computer. I had been living at Mercedes' house in Kañaris for about a week. During my fieldwork, there was no internet connection to the town or any public computers, which came in 2013. I had no idea what computer he could be talking about.

He brought me to a small office on the main street, where a group of men were gathered around a table with a laptop. It was after suppertime, already dark, and two of the men were fiddling with the electrical wires strung up the wall and ceiling, trying to get a stable electrical supply to keep the lights on and run the laptop. I did not know who anyone was, but everyone seemed to know me - the gringa, white lady — staying with Mercedes.

A middle-aged man sitting at the table told me that he had bought a second-hand computer, but it would not turn on. His name was Esteban, and he was the president of the community council. I inspected the laptop and found its battery needed to be charged. I helped Esteban set up a user account with a password, erased old files I found from the previous owner, and showed him how to open documents. The council's records were paper-based, as I could see from the stack of ledger books on the table. Perhaps he 
wanted the computer to compose letters, store photographs, and add a veneer of modern professionalism to the council's activities.

Esteban represented one of the political bodies in Kañaris, the one that oversees the allocation and use of land to community members in the town and surrounding area. Mercedes had already introduced me to the other political body, represented by the mayor. The mayor and his aldermen are responsible for activities throughout the entire district, and represent Kañaris to regional and national levels of government.

While Esteban is a local who lives in the town and farms like everyone else, the mayor is a businessman who lives in another town in the district. Locals consider him a foreigner. Although Kañaris is the district capital, the mayor only visits the municipal office every couple of weeks. Esteban had the wide support of the people, but the mayor had power, since he controlled the district budget and directly interacted with regional politicians.

Helping Esteban set up his computer was the one useful thing I was able to do for the community council. I took the opportunity to introduce myself to Esteban and the other council members present, and to explain my purpose in Kañaris. The president was polite, but he ignored my nervous offer to help him and the council in other ways. I hoped the symbolic gesture still communicated my good intentions.

That first week in Kañaris, I tried to introduce myself to as many people as possible. Everyone suspected I was either working for the local mine, or a Peruvian nongovernmental organization. I found the most intelligible way to explain my presence was that I was a student finishing my university "specialization.” I had come to Kañaris to study local customs, such as ritual healing and herbal remedies, so that I could complete 
my degree and become a university professor. I would add that I was a colleague of Juan Javier, the Peruvian anthropologist who had introduced me to Kañaris the previous summer, whom townspeople remembered and asked after.

In the following weeks, I tried my best to demonstrate that I was in Kañaris to attend festivals, collect stories, and learn about local "customs," as people say. It helped that at the first event I attended - a weaving competition - Andres' sisters dressed me in the long black skirt, colourful blouse, and wide-brimmed hat that almost all women wear. Ladies told me they were pleased to see a gringa in their dress. Some asked to have their photographs taken with me, which I promised to bring them next time I returned from the city.

\section{Locals and foreigners}

The ladies at the weaving competition were happy to see me dressed like them. Although I was a foreign visitor, they welcomed my attempts to show that I valued the way they did things. By putting aside my urban, white form of self-presentation, I hoped to symbolically align myself with Kañarenses rather than other white foreigners they encounter. Neither I nor my interlocutors were under the illusion that I could "become" a community member by doing so. Rather, I demonstrated my willingness to cross the boundaries of ethnicity, race, and class that most foreigners strive to maintain. As one resident foreigner from Cajamarca told me, "We have nothing in common with these people in Kañaris. We speak a different language, we dress in different clothes, we see the world completely differently." 
It is not just Peruvian visitors or colonists who make a distinction between themselves and people in Kañaris. Community members also maintain, comment on, and mark the differences between themselves and their neighbours. They distinguish between locals and foreigners, between those they are related to and those they are not, between who "belongs" to the community and who does not.

Mercedes, for example, is distantly related to most people in town, but she was born in another hamlet. She is a member of the "peasant community" of Kañaris overseen by Esteban and his councilmen, but her extended family — the lineages of her father and mother to which she is most closely attached - live four hours away. Thus while she is a local and a "natural" inhabitant of Kañaris, she is a bit of an outsider in the town.

I became closely associated with the family of Mercedes' neighbour, don Leonardo. After a couple of weeks in Kañaris, I moved into the house of his son and daughter-in-law, Andrés and Isabel. They are both from lineages based in the town, and "native" Kañarenses like Mercedes. Andrés and Isabel can each count on the support of their parents and siblings who live nearby. However, Isabel's father was deceased, and her brother had moved to the city. She lacked a male family member to defend her in times of interhousehold conflict. Perhaps this is one reason why she tended to keep to herself and defer to her in-laws, whom she had lived with when she first married Andrés.

The mayor, on the other hand, is not related to anyone in town. He was born outside of the district and moved here when he was young. He lives in the town of Huacapampa, several hours southeast of Kañaris (refer to Figure 3). Locals describe it as a settlement of foreign colonists, whom they call provincials, or "provincianos." Many townspeople are troubled by the power and influence they perceive these colonists to 
have. According to some community members, they have gained control of the political decision-making process that should be kept in the hands of Kañarenses.

There are other foreigners who regularly visit or live in the town. This includes a store owner and his wife from the valley town of Pucará; teachers who work in the school, often only for a year at a time; a handful of doctors and nurses at the governmentfunded medical post who come on monthly rotations from Chiclayo; a small group of Catholic nuns who live in the convent behind the church; and workers with a Peruvian non-governmental organization called the Centre for Social Studies "Solidarity" — or, as locals say, simply "La Solidaridad."

These resident foreigners are distinct from intermittent visitors who come for short periods of time at irregular and unpredictable intervals. For example, representatives of the Office of Public Defense, or the Peruvian Ombudsman, occasionally come to give human rights workshops and observe elections. Other visitors are employees of the Candente Copper Corp., who has hired Peruvian sociologists to visit communities, improve public relations, and gather information as they try to bolster community support for their proposed Cañariaco Norte mining operation. And a handful of Peruvian and foreign academics (myself included) have carried out anthropological, historical, archaeological, and biological investigations of a limited duration in the area. Locals tolerate all of these foreigners, and are even on friendly terms with those who have lived in the town for ten years or more, such as the storeowners, and two married teachers who are raising their children in Kañaris. But from the perspective of locals, such people are not related to them by birth or marriage, and so they can never "belong" to the community. 
Townspeople also observe that many foreigners want to change them to better reflect their own ideas of living a good life. Well-meaning visitors suggest this is for the benefit of the community, but locals do not always welcome people questioning their values and priorities. For example, one particularly devout lady told me that she no longer cures people by "cleansing with guinea pig" because the Catholic nuns told her it was bad, and that sorcery (brujería) in general is evil. Similarly, a nurse told me people did not come to the town's medical post because they were superstitious and would rather go to sorcerers (brujos). The implication of the comments of both the nurse and the nuns is that people should stop "worshipping" mountains and believing sorcery.

Other foreigners suggest that people in Kañaris are impeding their own “development." For example, workers with La Solidaridad encouraged people to grow cash crops to sell in urban markets. But they did not offer any resources for people to improve subsistence agriculture or generate a local market, which several householders told me would benefit them. And regional politicians pressured people to accept the Cañariaco Norte mine, which they said would generate jobs, even though locals feared it could also bring unpredictable environmental and social consequences. Indeed, the pervasive message from national Peruvian culture is that Kañarenses should abandon their "Indian" ways and become "modern," urban, people who emphasize their mixed descent as mestizos, instead of insisting on being different.

Yet as I came to understand the local perspective, traditional values and customary ways of living do not prevent people in Kañaris from participating in wider Peruvian society on their own terms. Esteban's use of the computer points to this very hope. As the elected president of the collective land-holding association of the peasant 
community of Kañaris, he is the political representative of Kañarense society, and directly communicates their concerns to the mayor and the municipal council. Yet even though his position and activities are grounded in the local socio-political context, Esteban wants to incorporate new tools and practices that enable him and the community council to better carry out their mandate and achieve their goals.

Esteban and other people in Kañaris want to be recognized as full citizens. They want others to recognize that they are not second-class people just because they do some things differently than others. Townspeople vote in regional and national elections, and they listen to news radio to learn what is happening in other parts of the country. Locals expect access to basic services, such as water and electricity, and they also want improvements such as better roads, and cellular and internet connections. Farmers want to continue to have title to the lands they cultivate to support their families. Parents want better living conditions and life opportunities for their children. Young adults want adequate education, a variety of work opportunities, and the choice to live another kind of life than their parents. Community leaders want to be able to make decisions about the inner workings and future development of their community.

In this chapter, I outline the local conception of the community and how people define themselves as Kañarense in distinction to other social groups. Locals understand themselves to be members of an extended family of people who are "natural" to Kañaris, who are politically represented by the peasant community overseen by Esteban and his councilmen. The implicit ideal is that community members should be equal and politically unified. But in reality, resources and power are unequally distributed, and people have diverse interests and divided allegiances. There is an underlying tension 
between the individual and collective good. One way this is indexed is through an unarticulated fear of vulnerability to social others, which finds its ultimate expression in malicious ritual acts intended to harm - that is, witchcraft and sorcery.

\section{The town}

The town of Kañaris sits on a wide and relatively flat hill, surrounded by rolling mountains on three sides. It overlooks a deep and narrow valley with the Kañariyaku River below. This river emerges in the mountains to the south of the town, and flows northwards into the Huancabamba River. Clouds roll in from this same direction before a coming rain, covering the town in a misty haze.

The town is located at approximately 2300 metres above sea level (Llatas Quiroz \& López Mesones 2005: 300), and straddles two distinct productive zones. Locals call the low-altitude mountainsides and valleys the "yunqa," where they grow manioc, sugar cane, oranges, bananas, and now the cash crops of passion fruit and coffee. The midaltitude zone is the "qeshwa," dominated by staples such as corn, wheat, barley, squash, peas, and beans. Here there are also pastures for sheep and cows, and forested areas where families gather firewood. Most community members cultivate small plots in both the yunqa and qeshwa within walking distance of their homes. Many people also have some high-altitude fields in the "shaqlla" for potatoes and other tubers.

The conceptual centre of the town is the plaza, a square area with a small fenced park and concrete gazebo. It follows the Spanish colonial model, with a church on one side and municipal office on the other. The other sides of the plaza are lined with small stores, row houses, the government medical post, and the high gate of the Catholic 
convent. Trucks arriving from the valley town of Pucará stop in the plaza to unload cargo and passengers. This dirt road continues in a semi-circle through the town, and then continues around the mountains on a narrower road to the next village.

Numerous footpaths cut through the surrounding hillsides. One main footpath north of the town climbs the mountains to pass through a sparsely populated area and eventually reach the Huancabamba River, some ten hours away. A shorter path leads to the cemetery just outside the town to the south. Other footpaths hike up the cultivated hillsides to the east of the town, or through lower fields to the south and west.

The western ravine leads to the Kañariyaku River. There is a wooden footbridge near the town's hydroelectric power generator upstream, but people walking directly from town cross the river by jumping on large rocks or wading through. Another line of mountains rises up on the other side of the river, dotted with more houses and hamlets. Beyond these visual borders of the town, past scattered fields and smaller villages, stretches the green expanse of the Upaypiteq Forest.

The town and immediate area surrounding Kañaris is home to approximately 500 people. Almost all people in the town (and district) of Kañaris are peasant farmers who supplement their agricultural production with temporary periods of paid employment (see also INEI 2007). A few residents in the town own stores or otherwise have a full-time income, such as Mercedes, who works at the school. But they are not set apart as a class distinguished by virtue of their access to resources or their lifestyles, even though these differences are recognized. While some individuals are indeed more prosperous and influential than others, there is no coherent, marked group of people in the town who have dramatically greater or lesser degrees of material wealth or political power. There is 
no local "ruling elite" that has inherited this position from their parents (see for example Gose 1994: 17-18, 31-42).

Yet beneath this relative equality and apparent social homogeneity, the town's residents present a range of belief orientations, life strategies, and priorities. For example, there are a number of people who have converted to Evangelical Protestantism. While religious conversion is more a fluid form of affiliation than a static state (see Steigenga \& Cleary 2007: 4, 6-7), Evangelical Protestantism in the Andes always entails some degree of distancing from traditional community rituals, and a significant shift in inter-household relations (see Sax 2011: 129-134). This is because traditional Andean-Catholic sociality involves practices typically forbidden by Protestant churches, such as drinking, dancing, and other ritual activities.

In Kañaris, the majority of townspeople are aligned with Catholicism, even though only a very small number regularly attend mass. They participate in the cycle of community festivals from Holy Week and the Feast of Saint John (the town's patron saint) to All Soul's Day and Christmas. They send their children to Sunday catechism classes at the Catholic convent. They also participate in the complex web of relations in which one individual and household is connected to another through ties of kinship, marriage, work exchange, food gifting, and - as these are often the basis for good relations - social and political support.

Evangelical Protestantism in Kañaris is not socially constructed in opposition to community membership, practice, and belief, at least in a strong or emphatic enough manner to register in the public sphere. Yet it is identified by some townspeople as symptomatic of a larger phenomenon of a perceived decrease in customary Kañarense 
practice, community cohesion, and social solidarity. This in turn is seen to weaken the autonomy and self-determination of the entire community in relation to the national government, transnational corporations, and other agents of the outside world.

On the other hand, Evangelical Protestantism can be seen as one of several alternative strategies for advancing the productive prospects of oneself and one's household, developing new social and political ties, and making sense of the vicissitudes of an uncertain life. Since there are other viable life strategies, other possibilities for life orientation, everyone need not feel compelled to continue to work insufficiently small plots of land inherited from their parents and interact in the same social networks in the town. Some people choose to permanently move to the coast and look for work in the city. Others move to the region closer to the Amazon jungle and take up new lands there. Those who stay in the town are not absolutely limited to traditional inter-household relations or autochthonous forms of social and political prestige represented by festival sponsorship and the community council. Some people purposefully build stronger ties to resident foreigners and the district municipal government.

\section{"Naturales" and "provincianos"}

From the local perspective, the most important social differentiation in the town is between "naturales" and "provincianos." In general Peruvian nomenclature, saying that an individual is "natural" to a particular locality identifies their place of birth and, it is largely assumed, cultural background. This is helpful in the context of widespread urban migration that has gained momentum in Peru since the 1940s, and which in the 1970s resulted in a demographic shift from a largely rural population to an urban, coastal one 
(see INEI 2009: 49-52; Matos Mar 2004). At the same time, the widespread Peruvian notion that certain territories are "naturally" occupied by particular people - that is, people of a subaltern class, ethnic, and racial position - implies that they "should" continue to live there, removed from the lives of the country's elites.

Nevertheless, thinking of oneself as a "natural" resident of a certain locality means that people are also the "original" occupants of lands from which they cannot and do not want to become alienated. This is marked in the term "originario," original to a particular place, which locals use as a synonym for "natural." Since legal title to land in rural, highland areas of Peru is closely tied to communal land rights, self-determination, and self-provision, this sense of the "natural" or "original" occupation of a particular territory valourizes collective and individual claims to place, class, and community.

It is in this self-valourizing sense that people in Kañaris occasionally use "natural" to indicate people who are members of families that have resided in the area since what they consider to be "time immemorial," and who now have communal title to a territory defined as the peasant community of Kañaris. That is, "naturales" are indigenous to this territory. The majority of the residents of the town and district of Kañaris consider themselves to be the "original" occupants of the territory, related under the "one great family" of Kañaris. Naturales share not only common kinship, residence, and way of life, but also customary practices that they say distinguish themselves from their neighbours. More specifically, the neighbours whom naturales define themselves in relation to are the foreign colonists and visitors with whom they do not hold these things in common. In other words, naturales are residents who self-identify (and are identified by others) as members of the "ethnic" group that they call "Kañarense." 
Given that they are the large majority, however, townspeople do not find it necessary to point out that they are "Kañarense" or naturales of Kañaris on a daily basis. It is the unmarked state of normalcy that is implied when another local category is invoked, which is frequent: "provinciano." This term is used to refer to a particular group of foreigners who reside within the district. As a direct translation, provinciano means "provincial," but its local meaning does not refer to the backwardness of rural populations from the point of view of urban elites. Instead, community members use provinciano to refer to people who have moved into the district from the neighbouring region of Cajamarca in approximately the past fifty years. Its etymology is probably connected to the neighbouring "provinces" of Chota and Cutervo in the region of Cajamarca from which these resident outsiders are believed to originate (see Alva Mariñas 2008: 265), and to which they are considered "natural." These national foreigners arrived as settlers who either appropriated or were granted lands specifically in and around the town of Huacapampa, several hours' drive to the southeast of the town of Kañaris.

Not all resident outsiders are provincianos, only those people and their descendants who originated in Cajamarca and have recently settled around Huacapampa. As they are widely believed to have arrived as migrant settlers, they are sometimes referred to as colonists, or "colonos." Like Kañarenses, these immigrants are also from rural, highland areas. They are situated in a similar class position of subsistence agriculture, temporary waged labour, and petty marketing. But both townspeople and Cajamarqueño colonists emphasize that they are not Kañarense: They do not have lineage ties to longstanding families in the district, they cannot make claims to territory based on 
ancestral inheritance now recognized in Peruvian law, and they neither demonstrate an abiding interest in nor desire to performatively affiliate themselves with practices that the "original" residents value as the correct way to live and emblematic of their community. These include public events such as annual religious festivals; household ceremonies concerning birth, marriage, and death; context-specific actions such as traditional forms of diagnosing and treating illness; and everyday practices including clothing, weaving, and speaking Quechua. The outside colonists are neither members of the Kañarense "family" of interconnected lineages, nor members of the peasant community of Kañaris, and they do not want to be so. A dedicated investigation of the social composition of Huacapampa would be necessary to gain a more informed understanding, but from the point of view of townspeople, the provincianos form a social and cultural group unto themselves.

The term "provinciano" is somewhat derogatory, but the underlying hostility is mutual, and the Cajamarqueño colonists reciprocate by calling the original residents "Kañarejos." Many naturales would prefer that these people from Cajamarca were not permanently residing within the district, but it appears that they are here to stay. In characteristic Kañarense form, this is rarely expressed through direct confrontation or overt conflict between individuals. Yet the hostility towards and mistrust of this particular group of resident foreigners is an ever-present undercurrent in the town.

\section{The local definition of the community}

Early on in my fieldwork, a man in town told me that Kañarenses make up one great family, the "ayllukuna" of Kañaris. This is the network of extended families who 
are related through birth and marriage, and who have lived in the highlands of Lambayeque for as long as they can remember. It is also the implicit ground of relation, unification, and legitimacy of the peasant community of Kañaris. The peasant community guarantees community members a place to live and land to cultivate to support their families. It is hard work, and there are things that they lack, but the approximately 3,200 adult members of the association choose to stay and continue to participate in the community.

The modern ayllu is the offshoot of a pre-Columbian form of social organization that linked kinship, access to resources, and political representation throughout the Andes. The ayllu was appropriated by the Incas, and became an important element of their expansive state administration and governance (see Gose 2008: 14-21; Murra 2002). In the pre-Columbian era, segmented lineages associated with particular places and under the authority of local lords were encompassed by higher levels of nested affinity and political authority. The organizational form of the ayllu persisted throughout the colonial period, in part because it facilitated the Spaniards' collection of tribute in labour and kind. It declined as the structuring mode of community interaction with the state after the Spanish stripped local lords of their power and authority in the mid-eighteenth century (Gose 2008: 277-278). Nevertheless, many Andean communities today continue to organize themselves into ayllus, often with an internal division between "upper" and "lower" moieties (see for example Gelles 2000: 98-117). Classic Andean ethnographies discuss the ayllu as the primary form of social and political organization both within and between highland communities, particularly in southern Peru and Bolivia (e.g. Bastien 1978; Harris 1989; Isbell 1978; Platt 1986; Rasnake 1988). 
My attention was drawn to the Kañarense notion of the ayllu because of what my interlocutors commented on and shared with me. People in Kañaris are proud that they are Kañarense, but not because this makes them "indigenous" or "Andean." They are just different from others, and this difference is intrinsically valuable to them. And how do people know they are Kañarense? Because of where they were born, how they were raised, and most importantly, who they are related to. The Kañarense notion of the ayllu points to the local conception of the community as grounded in kinship, residence, and territory. It also points to a self-fashioned (autopoietic) conception of the community as distinct from their immediate neighbours. From this perspective, the ayllu does not refer to an unbroken, pristinely "indigenous" lineage, but to locally relevant ways in which the present community members are related to one another, and not related to their neighbours. The ayllu is the local notion that organizes this community-wide relation and indexes community distinction vis-à-vis other social groups. In this sense, it fulfills a role similar to the notion of "ethnicity." In local terms, to be Kañarense is to be a member of the ayllu of Kañaris.

The ayllu persists in Kañaris not because it has always existed, or because people have no other form of social organization or basis for self-identification. It persists because being Kañarense continues to matter to the people who participate in the community today. Community members distinguish between their social group and others, between people who "naturally" live in this place and those who are foreigners, between people who are members of the peasant community and resident outsiders who are not. It is upon this basis of self-definition and internal notion of community distinction that I justify calling the community of Kañaris a distinct "ethnic" group. 
I do not intend to reify the notion of "ethnicity" (Barth 1969) by implying it to be something that exists in the world independent of its conceptualization. I use it here as an analytical category by which we may understand this self-fashioned marking and emphasizing of the community and group as distinct from others. Ethnicity is not so much about cultural content as the idea of difference. This state of difference and distinction in community "identification" (Brubaker \& Cooper 2000) is not, however, explicitly articulated by locals in terms of "the ethnic group of Kañaris." In Peru, ethnicity is entangled with notions of race and class. The self-essentializing force of ethnicity works against shifting racial and class signifiers - and the readiness of Andean peoples to symbolically re-position themselves in relation to others in order to gain a strategic advantage to accomplish their present goals (see for example Canessa 2012; Seligmann 2004). In the Peruvian context, peasant farmers who are ethnically distinct are "Indians," very low in the social hierarchy, and fated to continue to live in poverty, ignorance, and subjugation. The self-valorizing discourse of indigeneity reclaims cultural distinction for a postmodern vision of social identity that has room for the dignity of both tradition and advancement (see Canessa 2012: 7-10). But outside of areas of frequent tourism and the concentrated activities of non-governmental organizations - most notably Cuzco - indigeneity has not been taken up by Andean peoples in Peru as it has in Bolivia and Ecuador (see Cervone 2012; Colloredo-Mansfeld 2009; De la Cadena 2000, 2010; Lazar 2008). 


\section{Chapter conclusion}

The community of Kañaris is comprised of people who are related by birth and marriage, and whose interrelated familial lineages have lived and worked alongside one another for numerous generations in the highlands of Lambayeque. This interfamilial network is implicitly grounded in the pan-Andean notion of the ayllu. As we saw in the historical overview in the Introduction, the ayllu of Kañaris was formed during the early Spanish colonial period through the consolidation of Indian communities, or reducción. Contemporary community members consider themselves to be the "natural" inhabitants of the eastern region of the modern district of Kañaris. This "traditional" territory is now legally recognized through the peasant community.

The local conception of the community is not naturally occurring or pre-given. It is historically, politically, and socially contingent. Its membership can also change as these conditions change. Just why resident foreigners continue to be articulated - and describe themselves - as outside the community of Kañaris is an important question. Given the perceptions and relations of class, race, and ethnicity in Peru, I suspect that the Cajamarqueño colonists wish to maintain this distinction in part because they consider themselves to be "better," "more modern," or "more white" than the "backward Indians" of Kañaris.

Meanwhile, community members maintain that the "provincianos" are still outsiders even though they permanently reside within the territory of the peasant community. These resident foreigners may work and even live alongside community members, but they are not related to Kañarenses by birth or marriage, and they are not members of the peasant community. They do not perform being "Kañarense," and they 
do not participate in the webs of inter-household relations through generalized reciprocity and ritual activity.

Community members continue to struggle to provide for their families and offer their children the best possible future that they know of. Without education, money, or powerful social contacts, the land is one of their few resources. They do not want to become alienated from the land for several reasons. They want to continue to use the products of their own labour as subsistence farmers. They have a place to live with dignity and independence even if they do not have much money. And they have legal recognition of their right to occupy and use the land through the peasant community. Community members are not likely to relinquish their land rights by including people in the peasant community who are not direct family members. Land is one of the few things they have, and there's already little of it to be redistributed to their children.

The town of Kañaris is both the centre of the peasant community, and the capital of the larger district. It is the place where these two parallel frames of social organization meet and sometimes collide. The district includes much land and many people who are not members of the peasant community. The peasant community of Kañaris comprises roughly half the total territory and a quarter of the population of the district. Members of the peasant community consider themselves to be distinct from other district residents. I argue that this distinction is important to community members not simply because of the cultural politics of identity, but first and foremost because they have a vested interest in preserving their land ownership through the peasant community.

Community members value building connections with the outside world where these connections are strategic to forwarding their own goals and desires. But they are 
also wary of foreigners, particularly when they are seen to threaten individual persons or the good of the community as a whole. Locals consider a particular group of resident outsiders who originated in Cajamarca - the "provincianos" - to be threatening and morally questionable people. From the point of view of community members, these resident foreigners have taken control of the municipal council, which is the primary political mechanism by which the district is represented to higher levels of government. Many community members are disappointed that resident foreigners have the political power to make decisions that affect their community.

Threats to both the ethnic group and individual body-subject are perceived to come from the outside, and this is what locals emphasize in conversation. The more time I spent in Kañaris, however, the more I came to understand that the lived political, social, bodily, and spiritual threats of everyday life originate from inside the community itself. As we will see in the following chapters, illness, sorcery, production, and everyday life are situated within a range of culturally specific practices that index, manage, and reproduce these ambiguous yet ontologically pre-given threats. 


\section{Chapter 2: Local Politics}

Holy Week in Kañaris starts with the Passion of Christ on Good Friday, a daybreak procession reenacting Jesus carrying a cross on the way to his crucifixion. At five o'clock in the morning, I walked with Isabel in the dark to the church. About a hundred people were already gathered, including Andrés, who was in a wooden pew on one side where most of the men were sitting. As usual, Isabel and I sat on the other side of the church with the women and children.

The nuns led a mass, and then the procession began. The day before, a group of boys had carried the large wooden cross down from "Calvario," a hilltop overlooking the town. The mayor now carried the cross on his shoulders out of the church, followed by the faithful and the nuns, who sang liturgical songs through a handheld megaphone. We walked down the main road, and then turned onto a side path to climb the hills on the eastern side of the town.

In this Catholic ritual, there are fourteen traditional stops, or "Stations," each commemorating a significant event during Jesus' path to Mount Calvary. As our procession stopped for each of these Stations, the nuns read a passage from the Bible relating the relevant event, and they led prayers for particular people in the community. Then another man took up the cross, and the procession continued with the singing congregation. 
After about an hour, we reached the top of Calvario. The sun was now in full strength, with a wide and clear sky. The cross-bearer placed the cross in a niche in the ground in front of a small, dilapidated chapel. When the nuns had finished the final reading and prayer, several community leaders took up the nuns' megaphone to make short political speeches. To me, this seemed spontaneous, but I'm sure some of the individuals were planning to say something as we were hiking up the hill. Even if the nuns didn't expect this, townspeople likely did, since such speeches are typical of community events in Kañaris. They are among the few opportunities that political representatives and unofficial community leaders have to address a large number of community members.

The mayor spoke first, saying that this was the first year he attended Holy Week in Kañaris, and thanking people for receiving him during the first year of his term. Then the senior nun briefly talked about how people should demonstrate their religious devotion and protect the cross by rebuilding the chapel, which has fallen into such disrepair that it lacks a roof and only some low walls of old adobe bricks remain. Next a member of the community council, the Justice of the Peace, spoke. He agreed that the chapel should be rebuilt, and noted that at every moment more local "customs" are being lost.

Then Andrés took up the megaphone. He didn't hold a local political office, but he often addressed the community at such events. He had run for district mayor in 2010, but lost against the present mayor. Andrés chastised the participants - many of whom were attached to the mayor and the municipal council, and lived in other parts of the district — for treating the Passion of Christ as an entertaining outing or folkloric 
spectacle. He said people should recognize it as a serious event and demonstrate religious devotion, especially those from other communities who don't know the local customs. People should show respect by following the cross, not running up ahead to take photographs, as many of the visitors in the mayor's entourage — and I — had done. Andrés then turned to the chapel, saying that it had been constructed in a time of plague that killed all the animals. An unnamed priest built the chapel and the cross to protect the town. I heard similar stories from other townspeople, who described four chapels with four crosses that once surrounded the town and protected everyone from evil. But this is the only cross that remains. Andrés said there should be a communal work party to rebuild the chapel. Community members shouldn't depend on the organization or payment from the municipal council to do it. They should rebuild the chapel by their own initiative and work, as it used to be. Moreover, they shouldn't stop at the chapel. The community should also build stairs leading to a lookout at this spot, which affords a good view of the town, and which could be an attraction to promote tourism in the district.

When Andrés had finished, the mayor took up the megaphone again. He was not a gifted orator as Andrés was, but he tried his best to make a spontaneous and compelling speech. The mayor said he thought tourism was good, and that the municipal council will organize a work party in collaboration with the community council. They will all work together so as to not lose this custom. This garnered more heartfelt and enthusiastic applause than his first, rather uncharismatic, speech. Everyone then made their individual way back down the hill. 
When I arrived in the town, I found a small group of people talking in a circle about rebuilding the chapel. There was the community president - Esteban -, Andrés, the mayor and some men from the municipal council, Mercedes and another local schoolteacher, and a couple of other respected community members. They were discussing not just rebuilding the chapel for the next year, but also promoting, preserving, and revitalizing various customs surrounding Holy Week. For example, Andrés informed the mayor that traditionally, the mayoral authority should be transferred to two "corporals" who regulate the activities of Holy Week. A local law upholds the temporary authority of the corporals, and the mayor is morally and legally obligated to respect this custom.

The mayor indicated his support for the development of cultural and ecological tourism in the district. But as people told me later, he was really in favour of an opposing model of development through the endorsement of the Cañariaco Norte mining operation. Everyone was very diplomatic and said all the right things to acknowledge the priorities of others. Several times, community members present said they must work together of their own "volition and sacrifice" to rebuild the chapel and do other community work, such as maintaining roads and constructing irrigation canals. As Andrés later told me, this sort of communal work often happened twenty years ago, but it has almost disappeared since the mayoral office became a paid position and the resident foreigners called provincianos took an interest in running the municipal council. The discussion ended with tentative plans for a meeting in one or two weeks, with the inclusion of respected elders as well as the local community council. Later, however, people told me that every mayor has promised to rebuild the chapel, but nothing ever happens. 
At the time, I did not realize how politically charged this discussion and the speeches that prefigured it were. This entire event and exchange point to some of the things that concern community members: On one hand, the existence of evil, the management of risk, and whether one can trust fellow community members. On the other hand, the desire for political self-determination, economic development, and cultural continuity.

\section{The municipality, the community council, and the underlying dilemma}

There are two levels of government effectively present in the district of Kañaris. The municipal council coordinates activities and expenditures for the entire area, and mediates the administrative and political relations between the district and higher levels of regional government. The district has a population of 13,000 people spread across approximately seven hundred square kilometres (INEI 2007; Municipalidad Distrital de Kañaris n.d.). This area is unequally divided among four peasant communities. The two largest and most prominent are San Juan Bautista de Kañaris in the east - with an area of approximately $210 \mathrm{~km}^{2}$ - and Túpac Amaru II in the west, with $480 \mathrm{~km}^{2}$ (see Municipalidad Distrital de Kañaris n.d.). San Juan Bautista de Kañaris represents the descendants of the "original” inhabitants of the area, and Túpac Amaru II represents families of tenant farmers who previously worked on large estates.

The "district municipality" is the smallest level of government recognized by the state, but it is only intermittently present to people in far-flung rural towns and villages. In terms of daily administration, conflict resolution, and security, the local peasant communities are more important. These two levels of government come to a head in the 
town of Kañaris, which is both the capital of the district, and the political and social centre of the peasant community (comunidad campesina) of San Juan Bautista de Kañaris.

The speeches made by the district mayor and local political leaders during the Passion of Christ point to the tensions between these two levels of government. Many townspeople I talked with suggested they believed the municipal council should be comprised of people who are also members of the extended family of the ayllu of Kañaris. That is, the local ideal is that the district municipality should include at least one of the approximately 3,200 adult members of the peasant community. ${ }^{6}$ Then the municipality would also represent the interests of the peasant community. But within the past two decades, the resident foreigners called provincianos have gained control of the municipal council. From the perspective of locals, this has serious consequences for the future development of the peasant community.

In the 2010 mayoral elections, Andrés led a grassroots political party, Pulla Kañarispaq (Together for Kañaris). He had strong support from the town of Kañaris and surrounding villages and hamlets, but although he campaigned across the district, only a minority of people voted for him in the western half. The present mayor lives in the town of Huacapampa, and most locals I talked with explicitly identified him as a provinciano. From the perspective of community members, the mayor represents the interests of these resident foreigners rather than the ayllu of Kañaris.

For example, the mayor endorses the Cañariaco Norte mining project, which Andrés and other community members believe threatens the local ecological system on

\footnotetext{
${ }^{6}$ According to Esteban, the community president, there were 3,214 members of the peasant community in 2009 (Juan Javier Rivera Andía, personal communication, June 2013).
} 
which their subsistence agriculture depends. In addition, the proposed mining site is on land legally held by the peasant community of San Juan Bautista de Kañaris. Community members' parents and grandparents worked hard to have their land rights recognized by the Peruvian government, and they have a vested interest in protecting these rights, which are the basis of not just their livelihoods, but also their collective self-determination.

In this chapter, I unpack these issues by contrasting the local ideal of community solidarity with the complicated reality of divergent interests. This matters not just because people observe the lived social world does not correspond to their ideal narratives. From the perspective of community members, what is at stake is both the "advancement" of their living conditions and life prospects, and their continued existence as a distinct political and social group.

From another perspective, however, the contrast between the local ideal and an imperfect reality point to the internal political and social dynamics of the community itself. In some ways, community members do not recognize their active role in the social and moral implications of this disparity. The local narrative allocates responsibility for the lack of trust and cooperation to the presence and actions of people they classify as "foreigners," rather than community members themselves.

Perhaps if people acknowledged their central role in this local drama, it would contradict the foundational idea of the community of Kañaris as "one big family" of equals who work together for the common good, or at least a common goal. The rhythms of day-to-day life in the town are pragmatically grounded in this valued assumption. As we will see in forthcoming discussions of the family, ties between individuals and households exemplify and reproduce community solidarity. Nevertheless, the local 
practice of sorcery indicates that internal cohesion exists alongside profound social fractures. Since illness due to sorcery is almost always the result of ritual actions that one community member does to harm another, sorcery transgresses a basic ethical principle in Kañarense society: that community members should help, and not harm, one another. Before we turn to these micro-political issues, however, we need to outline the stage upon which they are played out.

\section{"The provincianos are a wedge in community solidarity"}

Politically engaged people in Kañaris such as Andrés say that when they were younger, community members worked together to maintain the town and make their lives better. The municipal council did not have funds for roads or other public infrastructure, and townspeople did not wait for others to provide this public service. During Holy Week, the temporary authorities Andrés told the mayor about oversaw the communal cleaning of the roads. Men used shovels to clear weeds and stones, and machetes cut back encroaching tree branches. Before the 1990s, there was no truck road that linked the town to the highway at Pucará, and this manual labour was sufficient to maintain the footpaths in and around the town.

In addition, while today people can buy some foodstuffs at stores in town, before people had very limited access to commercial goods. Men travelled for weeks with donkeys carrying bags of dried corn to the coast, which they sold to purchase salt, rice, and other items to bring back to their families. During Holy Week, there was also a largescale exchange of agricultural products. People from other villages came to the town, and traded fruits from the lowlands and potatoes from higher altitudes for corn and other 
foods produced in Kañaris. This trueque exchange no longer takes place, although individual households continue to directly exchange agricultural products on a smaller scale at less predictable times of the year.

Several decades ago, the authority of the peasant community council was more prominent. For example, Isabel's elderly uncle told me, the men on the community council used to have staffs of office, carved out of a special wood and decorated with coloured ribbons (see also Sevilla Exebio 2005: 50). These staffs were transferred to incoming members of the community council, and they were used as an "insignia" of the office that had to be brought to each community meeting. The uncle's description of the staffs of office, and the succession of socio-political positions they accompanied, resonates with the cargo system of traditional authorities called "staff-holders" (varayoq) that has existed since the eighteenth century (see Gose 2008: 278-279), and which ethnographers have described in other Andean communities (e.g. Gelles 2000: 22-23; Isbell 1978: 84-93). But in Kañaris, these staffs have now been lost and forgotten, and the community council no longer uses them.

A more troubling change for community members is that the peasant community council has to defer to the municipality more often than they remember in the past. For example, several community members told me that in 1989 , the president of the community council organized a public demonstration of traditional medical practitioners, including midwives, herbalists who do "cleansing with guinea pig," and ritual specialists who heal through sorcery (brujería). According to my informants, such a demonstration is not held now for fear of being accused of causing sorcery illness. Yet I also observed that the community council could not seem to organize any public events nowadays 
without the support and endorsement of the municipality. For example, people told me that preparations for Holy Week in 2011 were delayed because the municipal council was unwilling to submit the necessary paperwork to formally sanction the traditional activities. And to the best of my knowledge, the promised meeting to plan the repair of the chapel on top of Calvario never happened.

Community members who organize annual activities and want to start new initiatives are frustrated that it is difficult to have their goals realized. My interlocutors often blamed the municipal council, suggesting the mayor and his councilmen are ignorant of local customs, or unwilling to accommodate them, or just plain corrupt and disinterested in local priorities. The members of the community council and other community organizers I talked with articulated variations on a theme, which I have come to think of as a local narrative of an idealized past that they would like to restore.

It goes like this: Before the resident foreigners called provincianos came sometime in the 1960 s or 1970 s, community members worked together, as equal associates with a common vision, engaging in cooperative action for the collective good. Since the provincianos arrived, they have not just appropriated communal lands - they have also changed the social climate of the community from a default position of trust to one of pervasive distrust. The distrust engendered by the unjust presence and immoral actions of the provincianos has created a wedge in community solidarity. Now people are less willing to trust one another and work together for projects of mutual benefit. This fracturing has become more pronounced and serious since the provincianos came to dominate the municipal council in between 1990 and 2010. Finally, to add insult to 
injury, the resident foreigners' control over the political structure on the district level has occurred a mere fifty years after the peasant community was officially established.

Although my sympathies inevitably lie with community members, I do not take this Kañarense narrative at face value. But before I turn to the inconsistencies I observed, and how they changed my understanding of the local political dynamics, we need to know a little about the founding of the comunidad campesina of San Juan Bautista de Kañaris. This will tell us why the peasant community is so important, and provide the necessary backstory to untangle local narratives of the ideal community from the lived social reality.

\section{"Before, we worked together for Kañaris"}

As Andrés told me, community members worked together to establish the peasant community in 1958 (see also Alva Mariñas 2008: 266). The Peruvian government first recognized San Juan Bautista de Kañaris as an indigenous community (comunidad indigena). After nation-wide agrarian reform in the 1960 s, this was changed to peasant community (comunidad campesina). At the time, Peruvian political discourse subsumed indigenousness under class (see Kláren 2000: 342; Weismantel 2001: xxxiv). This was only partially successful, and today "peasant" is a euphemism for an indigenous Andean person.

The Peruvian peasant community ${ }^{7}$ is a legal category that recognizes the territorial rights of a group of people who can demonstrate their long-term occupation

\footnotetext{
7 “Through Law 24656, the General Law on Peasant Communities, the state recognizes the communities as fundamental democratic institutions, autonomous in their organization, communal activities, and land use,
} 
and use of a delineated area of land. It can be based on either kinship with a recognized "indigenous" population, or comprised of tenant farmers - who are often also Indian peasants of mixed ancestry, but without a cohesive sense of ethnic distinction - who once worked on large-scale estates (haciendas). As previously mentioned, this second type is the basis for the peasant community of Túpac Amaru II, situated in the western half of the district of Kañaris (see Alva Mariñas 2008: 259).

The hacienda was a type of rural estate in Peru and much of Latin America throughout the nineteenth and early twentieth centuries. In the 1910-20s, widespread Peruvian peasant revolts demanded the government dismantle the haciendas, and redistribute their lands to the tenant farmers who worked them, many of whom selfidentified as indigenous communities and the "original" or "natural" occupants of the land (see Kláren 2000: 248-249). The government violently repressed these early protests, but unrest among peasants and rural workers continued in the 1930-40s (Kláren 2000: 292-295). When peasant unrest exploded again in the 1950s, the government first responded with repression, but then began to introduce land reform (Kláren 2000: 311315, 321-322, 326-328). Meanwhile, the "white" and "foreign" estate owners (hacendados) began selling their inherited estates, which were increasingly unprofitable in the wake of massive peasant revolt and a changed national political and economic climate (see Kláren 2000: 328). Thus, haciendas continued to dominate highland and coastal Peru until President Juan Velasco Alvarado passed the more comprehensive

\footnotetext{
as well as regarding economic and administrative issues. The law (a) defines who may be community members; (b) makes community lands inalienable; (c) establishes the minimum necessary quorums for decisions relevant to the community, such as selling the land; (d) establishes the land use and land tenure system within the community; (e) defines the functions and powers of the general assembly and the minimum quorums needed to make decisions; (f) describes the functions and roles of the communal directive and the minimum quorums for decision making; and (g) regulates the main features of the economic system and community enterprises." (Deininger et al. 2012: 124-125n2)
} 
Agrarian Reform Law in 1969 (see Hopkins 1985; Kláren 2000: 342, 346-350, 357;

Miller 1967; Seligmann 1993).

From the perspective of the state and national elites, one of the primary purposes of Agrarian Reform was to reorganize landholdings into cooperatives to increase domestic production to support urban industrialization (see Kláren 2000: 341, 346). From the perspective of Andean communities, the main benefits of this process was that it broke up the large estates, released them from feudal-like relations of indebted peonage, and established their legal rights to lands they had occupied and cultivated for generations (see Hopkins 1985; Seligmann 1993). Through Agrarian Reform, Andean peasants hoped to secure legal claim to their homes and subsistence base. Through peasant community councils, they allocated individual use-rights to small parcels of land to community members (comuneros). In legal terms, these small parcels cannot be individually owned, but in practice inheritable use-rights often means that community members have de facto ownership of "their" fields.

People in and around the town began to work for territorial rights shortly after the district of Kañaris was established in 1951. Local leaders submitted their petition to have their lands communally recognized as an indigenous community in 1956 (Alva Mariñas 2008: 265-266). This would legally protect their agricultural lands, livelihoods, and way of life from hacendandos based on the northern side of the Huancabamba River, who were beginning to appropriate Kañarense land on the southern side (see also Alva Mariñas 2008: 264). The community's petition included an outline of the territory, a household census, and colonial land titles (Alva Mariñas 2008: 265-266). These titles 
provided documentation of the continuous occupation and use of a demarcated area by a network of interrelated, Kañarense, families for numerous generations.

According to both local oral history and Peruvian anthropologist Pedro Alva Mariñas, a significant area surrounding the town of Kañaris was never subsumed under a large-scale estate. This independent territory was bordered by haciendas immediately to the north and east (2008: 263-264). To the west, the heavily forested mountains of the Upaypiteq Forest separated the community from the haciendas that eventually became Túpac Amaru II. In the south, sparsely populated high-altitude mountains and plains provided another buffer for the haciendas that became the district of Incahuasi. While some people from around the town of Kañaris may have worked on nearby haciendas, my preliminary archival research indicates that a core of the community's territory was free from the direct domination of "foreign" hacendados, and removed from the administrative reach of regional and national levels of government. Andrés told me a similar story, saying the autonomous area included the town of Kañaris and the hamlets of Atumpampa, El Chorro, and Congona (refer to Figure 3). Outside of this area, the "natural" Kañarense inhabitants were obligated to work for "foreign" landowners, under the coercive eyes of overseers and foremen.

As in other Andean communities, older people in Kañaris remember the hacendados as cruel whites and mestizos who beat people, separated families, and claimed whichever women they desired. People living on lands controlled by an hacendado worked in "his" fields growing corn and raising sheep, and in his home as cooks, maids, and weavers. In exchange, they had use-rights to small plots of land to grow their own food and support their families. However, this subsistence base was 
insecure, as the hacendado could kick tenant farmers off the land or send them to work elsewhere, such as sugar plantations on the coast (see Gonzales 1980).

The autonomous area around the town of Kañaris was free from this, but according to Andrés, they were still vulnerable to periodic raids by armed bandits, called "montoneras." These were men who rode in on horses, stole valuables, and raped women. The montoneras terrorized Kañarenses between approximately 1920 and 1950 . The earlier end of this time frame corresponds to a period of heightened banditry in the Peruvian Andes documented in the south (see Poole 1988: 378-380). Andrés told me people were afraid the montoneras would steal the statues of their saints, to whom they were deeply devoted and "considered their gods." So they hid the saints when the bandits rode into town. Unfortunately, some of the saints were lost because of this. For example, townspeople hid the statue of Santa Rosa de Lima in a mountain called Cerro Campana. When they returned later for the saint, she was gone, and people said the spirit of the mountain had "grabbed" her. The current statue of Santa Rosa de Lima in the town's church is a replica made from photographs.

Andrés said the neighbouring hacendados also threatened the independence and security of Kañaris. "Little by little," he said, they were moving into areas closest to the Huancabamba River, such as the hamlet of Atumpampa. So community members began to petition the government to do something about this. Two men emerged as local leaders: don Víctor Huamán Reyes, and don Romualdo Bernilla Reyes. ${ }^{8}$ Ultimately, they were successful, and on October 10, 1958 the Minister of Labour and Indigenous Affairs signed a Supreme Resolution that established the indigenous (later peasant) community of San Juan Bautista de Kañaris (Alva Mariñas 2008: 266). The community's territory

\footnotetext{
${ }^{8}$ In order to be consistent with existing published material, these are their actual names.
} 
was demarcated by the Huancabamba River in the north, Lake Tembladera and Lake Shin Shin in the south, the Tocras River and the village of Congona in the west, and the hamlets of Huacapampa, Quinua, and Sábila in the east (Alva Mariñas 2008: 265; refer to Figure 3).

\section{Gaps in the idealized narrative}

Andrés emphasized that community members took the initiative and worked together to establish the peasant community. Pedro Alva Mariñas' work supports this local account. But when Andrés told me about the community members who led this process, I began to think that the local narrative of a community unified in the face of outside forces was more complicated than the tidy picture people would like to remember. If community members once worked in solidarity to achieve a political goal in the recent past, they also had internal social divisions in that idealized era. I do not intend this observation to unfavourably judge Kañarenses. Rather, I see it as acknowledging the complex dynamics of cooperation, disagreement, and recollection that are played out in every society.

According to Alva Mariñas, don Víctor Huamán Reyes played a key role in the community's territorial petition. Don Víctor's family had long guarded colonial land titles dating from the early seventeenth century (Alva Mariñas 2008: 263-264). They identified the community lands of Kañaris as held by a local lord (cacique) named doña Juana María Callaypoma (Alva Mariñas 2008: 264). ${ }^{9}$ This provided archival “proof” to

\footnotetext{
${ }^{9}$ According to Peruvian anthropologist Julio César Sevilla Exebio, these colonial land titles were dated 1672 (1998: 482). However, I have not been able to verify this.
} 
support the community's petition for the state to recognize their territory not just through long-term farming and occupation, but also through legal title. Don Víctor held these documents up until his death in 2011. Andrés said that they are probably lost now, buried or entrusted to a sorcerer, because don Víctor did not want to give them to his feuding sons.

Andrés acknowledged don Víctor's role and the importance of the colonial land titles. Yet he has read Alva Mariñas' article, and he suggested the scholar only got the story partly right. There was another local leader who was integral to the establishment of the peasant community, don Romualdo Bernilla Reyes (see also Alva Mariñas 2008: 266). Don Víctor is better remembered because he became "the first community president." According to Andrés, don Romualdo did not win this office because he was "good of heart," and he did not want to let foreign colonists take up land in the newly established peasant community. Don Víctor, on the other hand, was rich, influential, and ready to play the game of patronage, coercion, and self-aggrandizing petty corruption that - at least in popular conception - characterizes all levels of Peruvian government.

Andrés pointedly said that don Víctor was not the great benefactor and "moral cacique" that Alva Mariñas makes him out to be. Although don Víctor was a community member, he was unusually rich. He was called "the man of money from Kañaris." He had many fields with no fewer than twenty day labourers working on them for cash payment. This indicates he had monetary resources beyond the means of most people in Kañaris even today. Perhaps this prosperity had something to do with his frequent consultations with sorcerers, in whom he ardently believed. 
Andrés also said it was don Víctor who allowed colonists from Cajamarca - the provincianos - to permanently settle around the town of Huacapampa. According to Alva Mariñas, the Cajamarqueño colonists came to the district in response to the state's campaign to settle the "eyebrow of the jungle" (2008: 265). Andrés disputed this claim, saying that don Víctor illegally gave parcels of communally-held land to Cajamarqueños who were "criminals running from the law." He suggested don Víctor did this for personal gain, for example for illegal monetary payment or to strategically bolster his political support among this population. Whether the colonists gained land in Kañaris through such individual ties, by outright appropriation, or by some other means, the comments Andrés made illustrate the widespread belief in Kañaris that these resident foreigners are inherently threatening and morally suspect.

At the same time, Andrés said, don Víctor was a man "with vision.” He could get people to work together to accomplish things in the community, which is seldom seen today, at least in Andrés' opinion. But while Alva Mariñas represented don Víctor as a charismatic leader, Andrés described him as a local member of the rural elite, who rode in on horseback and demanded people work under threat of whipping. According to Andrés, it was don Víctor who ordered the town church to be torn down and rebuilt in a more "modern" style. This was around 1965, "in the time of [President Fernando] Belaúnde" (see also Alva Mariñas 2008: 266n8). Thus Kañaris does not have a traditional building that is valued for its cultural uniqueness and potential to attract government interest and domestic tourists today, such as the church in the town of Incahuasi, with its handsome thatched roof and carved wooden columns. 
Several community members suggested to me that in their youth and the time of their parents, people acted as they should, helping one another obtain the necessities of life, and making that life a good one. There were hard times, with disease, hunger, and violence, but they trusted in the goodness of one another. According to my interlocutors, customary forms of showing respect and the annual cycle of religious festivals have declined today. They obliquely suggested that if these "traditions" were revitalized, the proper moral order could be restored. Yet the stories Andrés told me about don Víctor indicate that even in the era that exemplified the ideal Kañarense community, people did not always demonstrate local moral values, such as equality, respect, modesty, and generosity. Like all people, don Víctor had the potential to do both good and bad. And as in all times, there were people who pursued personal gain at the expense of the common good.

As the months passed in Kañaris, I began to see more inconsistencies in the local narrative about how people in the community worked together before, and how the provincianos have created a wedge in community solidarity today. Some households have better fields and tools than others. Some people are always at the centre of political and social activity, while others watch or participate from the sidelines. Members of the peasant community can be selfish just like any other people, and even in this small community, resources and power are unequally distributed. People also quietly hold grudges and reproduce mutual hostility between families for wrongs committed years ago. Under the surface of harmony, homogeneity, and the day-to-day functioning of Kañarense society lays the full range of human experience and emotion. 
Second, if community members worked together in the past of their own "volition and sacrifice," when they did not have any government funds or support, why should this stop them today? Yet my interlocutors told me they could not rebuild the chapel for the cross of the Passion of Christ, plan community events, or start new initiatives without support and funding from the municipality. Moreover, several community members said they were unable to motivate people to spend their time and energy on projects of collective, rather than individual, benefit. For example, Andrés wanted to build an irrigation canal with the households who had adjoining fields. But few people would come to the work parties, even though an irrigation canal would improve the fields of all the families. Another woman who was a respected weaver told me the community council had obtained three foot looms from a non-governmental organization. She was willing to show other women how to use them, so they could start a weaving cooperative and produce weavings to sell in cities. This local industry could be a significant source of income for women, but no one would come to the meetings.

Finally, the presence of morally questionable foreigners does not account for the existence of sorcery. In its mode as malicious witchcraft, sorcery expresses conflict between community members, not between locals and foreigners. Even though the local narrative is that people do not trust one another and work together as they used to because of the provincianos, the wider context of what people say and do indicates it is actually fellow community members who pose the most present and daily threat to one's wellbeing. The implicit ideal is that community "insiders" - naturales and comuneros should be categorically trustworthy, cooperative, and prioritizing collective good over individual gain. This does happen, but there are also notable inconsistencies. Based on 
the private stories people told me in confidence, it is community members who are most likely to deliberately harm one another, either through physical action (theft, rape), or ritual intervention (sorcery as malicious witchcraft).

Community members do not like talking about the evils people commit against one another, but such things occasionally do happen. It is also significant that an individual speaking in confidence can name a specific community member who has committed a serious offense against them or their family, but the stories circulated about the shocking transgressions of provincianos do not identify specific perpetrators or victims. In these stories, provincianos are not individuals, but a general category. Even the victims are nameless: once some provincianos raped two nurses and left them naked to walk to the next town; another time others broke into the convent and raped all the nuns.

Despite townspeople's idealizations of a more "traditional" time, I do not believe community members want to return to the past. Kañarenses are neither isolationists nor cultural purists. Rather, the story of how they worked together to secure their livelihoods in the face of threatening outsiders matters because it is the standard against which they evaluate their present circumstances.

\section{The present political issue}

In the early twentieth century, the agrarian livelihoods and de facto autonomy of Kañarenses was threatened by large-scale landowners who were appropriating their land. The community protected their collective interests and gained legal land title through the establishment of the comunidad campesina of San Juan Bautista de Kañaris. Today, the 
community faces a similar threat. But unlike the remembered past, contemporary community members have divergent understandings of what is in their best interest, both as individuals and as a collective. This unfolds on several fronts, such as the support for the grassroots political party Pulla Kañarispaq, which only a portion of community members consider to be a desirable and feasible alternative to a municipal government dominated by provincianos. Another front is the importance some community members give to local "customs" such as weaving, dress, music, dance, and language. Other community members appear to be uninterested in organizing or participating in community events and the informal education of children to promote and reproduce such practices. The most prominent field of contention, however, is the endorsement of a mine on the peasant community's land.

This is an operation called "Cañariaco Norte," which is owned and operated by the Vancouver-based company Candente Copper Corp. The site is located approximately twenty kilometres southeast of the town of Kañaris, on a mountain called Cerro Jehuamarca. In 2002, Candente Copper Corp. acquired the mining concessions from the two companies that had carried out exploratory drilling in the area in the 1990s (Candente Copper Corp. 2011: 2-3). According to the company's prefeasibility progress report, in January 2004 they began exploration for an open-pit copper mine with an estimated life span of twenty-two years (see Candente Copper Corp. 2011: 3, 11).

Although the mine is located on the peasant community's land, the "General Law on Peasant Communities in Peru" only establishes inalienable "surface rights" to San Juan Bautista de Kañaris. Ultimately it is the state who "owns" the minerals and resources under the earth's surface and grants mining concessions (see $B B C$ News 
05/06/09; Latin Lawyer 24/04/14). Nevertheless, because legal peasant communities have surface rights, companies must have a ratified agreement with them to access the mining site on their land (see Candente Copper Corp. 2011: 5). Community opposition to consenting this access has stalled the company's mining activities (see El Comercio 22/02/14a). Yet the future of mining, development, and community in Kañaris is still uncertain.

This local issue is unfolding within a significant national context. From a purely economic perspective, Peru is doing better than it has since the guano boom of the late nineteenth century (see Kláren 2000: 158ff; The Economist 02/02/13). Mining is a key source of the country's economic growth (see Bebbington et al. 2009: 17297; Fuller 2009: 754; The New York Times 19/08/13). But this macroeconomic prosperity has increasingly been accompanied by civil unrest (see $B B C$ News 06/09/11). Besides endemic political corruption and drug trafficking, local opposition to mining in the Andes and oil exploration in the Amazon is the single biggest news item in Peru today.

Two key events stand out in particular. Protests against oil extraction led to a national crisis in 2009, which resulted in a deadly clash between police and civilians in Bagua, located in the jungle of the Amazonas region (BBC News 05/06/09, 10/06/09, 19/06/09; El Comercio 13/05/14; The New York Times 05/06/09). Then in 2011, the President declared a state of emergency in Cajamarca, where mass protests against a gold and copper mine, called Minas Conga, had essentially shut the region down (BBC News 24/11/11, 30/11/11, 05/12/11; El Comercio 09/11/11; The New York Times 14/06/10, $11 / 12 / 11)$. 
As a result of Bagua and other anti-mining protests, President Ollanta Humala passed the "Law of the Right of Indigenous or Native Communities to Prior Consultation" (BBC News 06/09/11; Peru Support Group 31/08/11). According to the BBC News, "The law requires companies to seek agreement with rural communities for projects that effect them or their ancestral territories, but does not give the communities the right of veto" (06/09/11). President Humala's purpose with passing the law appears to have been to diffuse indigenous and peasant protest while keeping the real decisionmaking power within the government's hands, in order to allow valuable private mining and oil projects to go forward (see El Comercio 22/05/13). The law was at first hailed by the international community (see Peru Support Group 09/09/11). But in the three years since it passed, it has been increasingly criticized by national commentators as ineffective in curbing mining protests (as in the case of Conga), and too vague in defining who is eligible to participate in the consultation process and when a majority of community members have voted in a referendum (as we will see happened in Kañaris) (see $E l$ Comercio 14/02/13, 21/04/14).

The most contentious issue is the law's definition of what constitutes an "indigenous" or "native" community. When the central government finally published a methodological guide for interpreting the law (see El Comercio 03/04/13; Viceministerio de Interculturalidad 2013), they continued to stall establishing a clear list of what communities qualify as indigenous or native (see El Comercio 05/05/13, 26/10/13; Peru Support Group 12/11/13). Some politicians even went so far as to disregard Andean communities that legally acquired this status as comunidades indigenas and comunidades campesinas. For example, the national newspaper El Comercio quoted President Humala 
as saying, "The highlands are mostly made up of agrarian communities that are a product of agrarian reform" (05/05/13). Such comments imply the only "real natives" are "noble savages" living in the Amazonian rainforest, thus excluding the thousands of Quechua, Aymara, and Spanish speaking peasant farmers of the Andean regions where the largest mining operations are located.

Numerous people I talked with in Kañaris knew about both Bagua and Conga, as well as the law on prior consultation. They were aware that their community is only one of many in Peru concerned about the environmental and social effects of resource extraction on their land. A couple of years earlier, Andrés had been involved in local demonstrations against Cañariaco Norte. He told me that government forces released tear gas into the crowd, and that he feared Isabel had been killed. Perhaps these protests surrounded Candente Copper Corp.'s negotiations with the peasant community to access the mining site in 2009 (see Candente Copper Corp. 2011: 5).

I was fortunate that no major protests occurred when I stayed in Kañaris in 2011 2012. I know that several community meetings took place about the mine, which I was not invited to. In October 2012, the overwhelming majority (95\%) of participating peasant community members voted against the Cañariaco Norte mine (El Comercio $01 / 10 / 12$ ). Although this was part of the official community consultation process, the Peruvian government refused to acknowledge the referendum's validity, saying that the almost 1,900 people who voted did not meet the minimum requirements of comprising at least half of the peasant community (El Comercio 11/10/12; Peru Support Group 04/02/13). In addition, a delegate of the Ministry of Energy and Mines said that since the community had failed to submit the required form with the signatures of all the 
participants, it was just a "popular assembly" and not an official referendum ( $E l$

Comercio 11/10/12). Paradoxically, the central government said they would accept the positive results of an earlier vote conducted the previous July, in which only 400 people participated (Ibid.). In response, the peasant community began organized protests against the mine (El Comercio 04/01/13; Peru Support Group 04/02/13).

Things came to a head in January 2013, when about 500 community members blockaded the road to the mining camp (El Comercio 21/01/13a; Peru Support Group 04/02/13). According to the national newspaper El Comercio, 300 policemen from Jaén and Chiclayo were brought in to subdue the protesters (21/01/13b). At first, some community members brought children with them, apparently in an effort to prevent violence (Ibid.). The next day, protesters carried stakes and stones, and the police fired tear gas and rubber bullets into the crowd (El Comercio 22/01/13, 25/01/13). There were some injuries among protesters, but luckily no deaths confirmed to be caused by the conflict (El Comercio 25/01/13, 28/01/13b).

For the first time, the peasant community of Kañaris was discussed in the national news and came to the attention of the country's elites in Lima. Community representatives agreed to begin talks with the Ministry of Energy and Mines when the Ministries of Culture and The Environment were added (El Comercio 02/02/13). Nevertheless, the president of the peasant community said he would only participate when the mining company definitively withdrew from the territory, a demand that the Minister of Energy and Mines refused to entertain (El Comercio 28/01/13a, 18/05/13). The blockades continued while representatives from the districts of Kañaris, Incahuasi, and Salas (Penachí) participated in several rounds of discussion with the central 
government. Two working groups were set up, one to discuss the mine and the environment, and the other to discuss sustainable social development (El Comercio $03 / 02 / 13)$

In May 2013, Candente Copper Corp. announced their discovery of gold and silver deposits close to the mining camp at Cañariaco Norte (El Comercio 11/05/13). Despite this lucrative find, the company "temporarily" suspended their activities in the district of Kañaris a week later, citing both the global economic downturn and ongoing community opposition (El Comercio 17/05/13).

That same month, the peasant community of San Juan Bautista de Kañaris filed a complaint against the Peruvian state for the infringement of their previously recognized indigenous rights with the Inter-American Commission on Human Rights (El Comercio 29/05/13; Peru Support Group 18/06/13). According to El Comercio, the community filed the petition with the support of the Lima-based Institute of Democracy and Human Rights (Pontificia Universidad Católica del Perú) and Chiclayo-based lawyer Wilfredo Chero Villegas (29/05/13).

This is a remarkable turn of the peasant community vocally asserting their indigenous status. Perhaps community members' protests against Cañariaco Norte, and their collaboration with communities with similar concerns, have created a "tipping point" towards embracing the contemporary discourse of indigeneity. In addition, the peasant community has the potential for significant political gains if they can persuade powerbrokers (such as the central government) that they once again qualify as “indigenous" in outsiders' eyes (see Li 2013 for a fascinating - if problematic discussion of an emergent notion of indigeneity in relation to the mining conflict in 
Cajamarca). If successful, the community will gain a strategic advantage, both under the Law of Prior Consultation, and in their petition to the Inter-American Commission on Human Rights. Their forbearers made a similar move is in the 1950s, in order to secure their lands and livelihoods through the establishment of the comunidad indigena / comunidad campesina of San Juan Bautista de Kañaris. Now community members are facing a comparable threat to their lands and livelihoods, this time against transnational corporations and a central government apparently set on expanding foreign investment at the expense of the social and environmental integrity of small communities far removed from Lima.

In February 2014, anti-mining protests in Kañaris resumed. In the six months of roundtables the year before, the central government said they would provide funds for the development of essential infrastructure in Kañaris and other districts in the highlands of Lambayeque, such as electricity, health centres, irrigation canals, natural gas stoves to replace smoky fires, and improved education (El Comercio 03/02/13). According to $E l$ Comercio, the government had promised to provide approximately CAD $\$ 38$ million in these sorts of initiatives for Kañaris, Incahuasi, and Salas (06/04/13). Ten months later, no "development" projects had materialized, and community members began protesting again (El Comercio 22/02/14b, 23/02/14). Esteban, the now former community president, said that the community is not against development; they just want the development politicians speak of to actually reach Kañaris (El Comercio 22/02/14b).

This is very similar to what Andrés and other community members told me in 2011-12. Kañarenses do not see themselves as "standing in the way" of development, as politicians and the national media often portray anti-mining protesters. Community 
members emphatically do want to improve and "advance" their communities. They want the government to provide them with the basic services enjoyed by other Peruvian citizens: clean water, electricity, roads, healthcare, and education. If the investment of foreign companies will contribute to this process, so much the better. At the same time, however, many community members are concerned that international companies will just extract natural resources and leave environmental and social destruction in their wake. They do not trust the central government to hold foreign companies accountable to uphold national environmental standards, if indeed they exist. They do not even trust the government to follow through with promises they have made to the community, as Esteban observed in the case of the millions of Nuevo soles the government said they would provide for local development.

\section{A community divided}

When I arrived in Kañaris back in 2011, I had to carefully distance myself from Cañariaco Norte, Candente Copper Corp., and any interest in the mine. Foreigners rarely visit the town. Locals thought that if I was not affiliated with the medical post, the nuns, or a non-governmental organization, then I must be working for the mining company. This was compounded by two additional factors. Townspeople told me Cañariaco Norte has hired two or three female Peruvian sociologists who visit the town of Kañaris and other villages close to the mining site. Although I met two of these sociologists during the Fiesta de San Juan in 2011, I purposefully did not ask them what they were doing. It seems likely they facilitate public meetings about the mine and try to improve public 
relations. Townspeople told me they were "spies" gathering information for the mining company.

Second, people told me the "owner" of Cañariaco Norte is a gringa, a foreign white woman, just like I am. She has apparently visited the town and the site, so locals have seen her. I assume people were referring to Joanne C. Freeze, the CEO, Director, and Chair of Candente Copper Corp. I tried my best to demonstrate to townspeople that I really was just a student interested in their local customs. Whenever I met people from surrounding communities, I had to patiently explain that I had nothing to do with the mining company.

Despite my purposeful avoidance of asking questions related to the mine, after I had spent several weeks in Kañaris, people started telling me things. I learned that some townspeople had once worked at the mining camp set up for exploratory drilling, which currently has a staff of about 100 people (see Candente Copper Corp. 2011: 4). I assume locals are hired to assist with construction, surveying, translation between Quechua and Spanish, and camp maintenance (such as cooking). Locals told me Cañariaco Norte also approached other individuals, offering a monthly wage in exchange for the explicit endorsement of key community members who could influence popular opinion within the peasant community.

Working for Cañariaco Norte is a sensitive topic in the town, since it unequivocally demonstrates one's acceptance of the foreign mining company and their operation. I suspect that individuals who choose to seek employment at the mining camp have weighed the personal benefit of paid employment against the potential social consequences. People told me the daily wage at the camp is approximately six times what 
one could expect to make as an agricultural labourer. Every household needs some form of monetary income to supplement their subsistence farming. Locals told me villages located closer to the mining camp are more supportive of the operation, because it offers a rare opportunity for paid employment within the district.

Nevertheless, community members are deeply divided in regards to the mine. Some community members, especially those who work closest with the municipality, said they believe the mine would be good for the local economy and the "development" and "modernization" of the district. Other community members said they too want to "advance" the community and improve living conditions, but not at the expense of their ability to continue farming or the community's self-determination.

The position of the peasant community council seems to be that those who are in favour of the mine are interested more in their personal gain than the good of the community. For example, the mine could be a valuable source of employment for some local people, but how will the influx of foreign workers affect the community? Will these men take advantage of local women? Will violence and insecurity increase, as people believe happened with the arrival of the provincianos? The mine will generate money, but most of the profits will go outside of the district. A few individuals and families will benefit, but what about the community as a whole? And what will happen when the mine suddenly shuts down in twenty or so years?

Furthermore, the proposed mining site is located in the forested mountains that are the basis of the watershed that local agriculture depends upon. These mountains are the source of the Kañariyaku River, which runs past the town, and the humid cloud forest is an integral part of the local rain system. Although few people live in the Upaypiteq 
Forest, it is home to rare plants, speckled bears, and other animals. Community members such as Andrés recognize its ecological significance and essential role in local agriculture, and they do not want large parts of the forest to be cut down or their waterways polluted by run-off from the mine. The lack of environmental regulation and political accountability make this a likely possibility, and it has already happened in other Peruvian communities (see for example Bebbington \& Williams 2008; Bury 2004: 85-87; Fuller 2009: 754).

These are the misgivings townspeople expressed about Cañariaco Norte in 201112. Despite the legal status of the peasant community of San Juan Bautista de Kañaris and the new Law on Prior Consultation, it seems likely the Peruvian government will continue to push for communities to accept - or at least concede to - the presence of mining operations on their lands. The only recourse community members seem to have is public protest (see also Bebbington et al. 2009: 17299). Based on newspaper reports since 2012, it appears that community members are again working together to protect their common interests in the face of powerful outsiders.

\section{Chapter conclusion}

I have argued that there is an inconsistency between the cultural ideal of community solidarity and the lived reality of socio-political fracture in Kañaris. In the macro-political regional, context, people in Kañaris are indeed vulnerable to powerful outsiders. The Peruvian government and transnational corporations have their own vested interests, which may be in conflict with the community's goals of maintaining the base of their agricultural livelihoods, improving their living conditions and life prospects, and 
retaining their local self-determination through the political relevancy of the peasant community. Yet when these community interests are threatened, fault does not always lie with the provincianos or another category of foreigner. On the micro-political level, the real conflicts and vulnerabilities are between fellow community members - neighbours, work partners, ritual kin, and extended family. These are also the people one "should" be able to trust the most.

The existence and practice of sorcery is one of the ways these social fractures are manifested in Kañaris. Sorcery expresses conflict between fellow community members, not naturales and provincianos. Illness attributed to sorcery is almost always the result of ritual actions intended to harm someone personally known to the perpetrator. This is what I call "malicious witchcraft," to differentiate it from sorcery as a genre of healing.

Sorcery as malicious witchcraft transgresses foundational community values and ethical principles in Kañaris. Local nostalgia for the recent past illustrates the cultural ideal that community members should be equal members of "one big family," the ayllu of Kañaris. People should work together for the benefit of the community as a whole, not private accumulation. They should do this especially in the face of threatening foreigners and community outsiders. Community members should help, and not harm, one another. And they should exemplify respect, modesty, and generosity.

In everyday life, people do generally strive to live according to these local ethical principles. In the following chapter, we will see the practices that bind families together, connect one household to another, and extend the network of reciprocal help beyond the immediate family. Individuals and households $d o$ work together for mutual benefit, and this enables people to meet their daily needs, provide for their families, and have valuable 
social relationships. Once I have outlined the contours of day-to-day life in Kañaris, we will return to the troubling undercurrent of vulnerability, conflict, and sorcery. 


\section{Chapter 3: Family and Household}

Someone was urgently knocking on Andrés' door in the middle of the night. At

first he tried to ignore it. People never answer the door late at the night, unless expecting a visitor, for fear that someone - or something - malicious and dangerous might be on the other side. But the person persistently kept knocking, so he finally answered the door. Someone had come to talk with Andrés. They wanted to ask him if he would act as godfather (padrino) of the young man who had eloped with their daughter. The girl's mother and father needed to find a padrino to begin the formal marriage by assisting the boy to ask permission from them. Community members call this the pedimiento, a local Spanish-derived term that means making a formal request. The young man had no godfather, so the girl's family asked Andrés. He declined, telling the person at the door that an older and more experienced man should become godfather. The family persisted, and asked him again. He declined a second time, but agreed to help them find a godfather and a candle-bearer (velero) to help the padrino.

Andrés resisted accepting the responsibility of godfathering the young man. In the approaching marriage, the padrino would have to drink sugar cane alcohol with the boy's father and discuss the possibility of a marriage. He would have to visit all the girl's close relatives with the boy's father, invite them to the wedding, and give advice to the couple on their wedding day. More worrisome, if the marriage fell apart, everyone would blame the padrino. 
A traditional marriage - through which the couple seeks public recognition of their desire to form an independent household - needs a padrino. In the ideal case, a marriage request takes place before the couple elopes, that is, in the local turn of phrase, when the boy "steals" the girl. First, a boy tells his parents that he intends to marry someone. Then, his father helps his son find a godfather and his assistant, the candlebearer. Ideally, respectable and reliable middle-aged married men fill both roles. Only with a padrino and velero can wedding arrangements begin. Since the union of a couple will affect the future of the individuals involved and all members of their immediate families, the marriage request is, in some ways, more important than the wedding ceremony itself. The padrino mediates the alliance between the couple's parents. These marriage relations serve as the basis for political and economic links across households and lineages. Even if all parties are enthusiastic about creating ties, negotiations should take place to set a tone of mutual respect for future family relations.

A month after Andrés received the midnight knock, the young couple married in a nearby hamlet in the house of the bride's parents. Lupe and Nicolás, two married resident schoolteachers from Cajamarca, served as godparents. They became co-parents (compadres) to the parents, and godparents (padrinos) to the couple. Although not Kañarense, Nicolás and Lupe have worked and lived in the town for a decade. Socially progressive and sympathetic, they willingly interact with community members, partially on local terms. They have a house in the town and three school-aged, Quechua-speaking children who play with their neighbours and classmates.

Andrés and Isabel did not attend the wedding, but Lupe invited me. The marriage celebration followed a script common to all household ceremonies and festivals in 
Kañaris. Guests started arriving in the evening. We sat against the walls of the front room of the house while the bride's father and other men of the household served us sugar cane alcohol (yonque) and sugar cane juice (guarapo). Community members always offer and receive these drinks in a specific way. The host pours a small mouthful of yonque in a glass and offers it to the guest saying, "Let's drink together," or "Tomakushun" in Quechua. This phrase combines the Spanish "tomar," to drink, with the Quechua suffixes "-ku," which indicates reciprocity, and "-shun," which marks the first person plural inclusive imperative. Thus the phrase more literally means, "You and I must drink together." Hosts may also say “upyakushun," which also translates as "Let's drink together," but uses the Quechua root "upay" for the verb to drink. In either case, a guest receives the glass, points it towards the person next to them, or occasionally a specific person seated elsewhere, says "Let's drink together" - "tomakushun" - and gulps down the distilled cane alcohol. Drinkers shake out drops onto the ground at the end. As people consider outright refusal impolite, they may stealthily "shake out" a serving after receiving several rounds. Woman may pour yonque into an empty plastic bottle they have purposely brought, or, having received at least one drink on a previous round, refuse the drink altogether. Men find it difficult to refuse drinks. Throughout the night, one of the bride's uncles sitting beside me asked me to pour the many rounds of yonque people offered him into my bottle. Although women and men sit separately at festivals and public gatherings, by chance I sat with the men instead of the women.

The visiting and drink exchange continued for several hours. Before the marriage couple appeared at midnight, several people were drunk, including the co-parents Lupe and Nicolás, who had already shared several prerequisite bottles of yonque with the 
family. Then the bride's mother brought in her daughter from the back of the house. The bride sat at the front of the room, beside her godmother, Lupe, and her parents. The groom arrived at the front door, where he kneeled, while the bride's uncle greeted the parents and asked their permission for the groom to enter. The godfather ought to have done this, but as an outsider Nicólas did not know his role. He sat the groom down next to the bride, and took his seat on the groom's side with the velero, a cousin of the bride's mother, who was holding a lit candle. The padrinos and parents of the bride drank a serving of yonque to each other. Several important guests then shared yonque and guarapo with each other.

The bride's uncle explained to the padrinos what must happen next. The bride and groom each drank three gulps from two small bottles half filled with yonque. They intertwined their arms and held the bottles, which they brought to their lips, exchanging bottles after each time they took a drink. Neither of them had regularly drunk strong alcohol, and from the expressions on their faces, they did not find the task pleasant. The young couple then had to finish their bottles of yonque, exchanging the bottles regularly. Lupe and Nicolás, as the padrinos, drank what the couple could not. In earlier times, the marriage couple each had to drink three half-bottles of yonque.

The groom then knelt on the ground in front of his godmother, Lupe, to receive marriage advice from her. When she finished, he returned to his seat. The bride's uncle said the groom should kneel in front of each of the speakers, and a short debate followed about whether this should happen. Lupe called on different women to give their advice: the groom's grandmother, the bride's two maternal aunts, and a prominent herbalist related to the bride's family. Next, the godfather, Nicolás, took a glass of yonque and 
gave his advice. Then the herbalist's husband spoke, followed by two of the bride's uncles, and two other men who I did not know. The middle-aged and married people providing advice spoke in Quechua, except for the padrinos, who spoke in Spanish. The bride's uncle also switched to Spanish halfway through his advice, for the benefit of the padrinos. There had been a muted conflict about the godmother's advice. Not everyone agreed with Lupe's emphasis on marriage as an equal partnership.

The marriage ceremony took an hour. When it was done, people stood up to offer their congratulations. Someone turned the music on, which blared through large speakers just outside the house. The parents, godparents, and marriage couple started the party with a traditional Kañarense takiy. In this dance, alternating men and women gather in a circle, hold their arms around their neighbours' backs, and quickly spin together first in one direction and then the other. After this, guests got up to start dancing in pairs of women and men, lightly hopping up and down to the beat, sometimes twirling around, but never touching. As in all local festivals, the music included Andean huaynos and northern Peruvian cumbia and chicha.

After about a half an hour, the feast began. This also followed the Kañarense script for household and community festivals. A senior man said a prayer to bless the meal and the bride's father placed a white cloth, with a small woven blanket on top of it, on the ground in the middle of the room. Other men poured a mass of boiled corn kernels called mote, similar to hominy corn, on top of the blanket. Next to that they deposited a similar pile of boiled manioc. They placed a large plastic tub with a roasted sheep on top of the corn and manioc, with a couple of small bowls of salt. On either side of the blanket they put two small plastic buckets of guarapo, and a bottle of yonque at each corner. Four 
large bowls of clear broth soup made from the meat drippings, with pieces of meat, boiled potato, and fresh cheese, were also at each corner of the blanket. Two men cut the roasted sheep by tearing the meat into medium-sized pieces with their hands. They divided it into individual portions while separating the tender meat from the chewy sinew, and they cut out the largest bones, leaving them aside for later.

Then several men brought each guest a bowl of soup, running back and forth between the kitchen and the front room. This soup, different from the meat drippings, was thick and savory, with whole wheat kernels. They gave a few guests, visitors from outside Kañaris, spoons. People talked while they ate their soup. Some men asked for a second bowl, which their hosts happily provided. People consider it ungracious not to finish at least one bowl. One or two guests took up the clear broth soup from the blanket, ate a little, and passed it on to their neighbor.

After everyone had finished their soup, men went around the room to use each guest's bowl to scoop up some of the mote and manioc for them. Then they came around with the tub of meat, handing a little to each guest. They offered special guests second or third helpings until they had distributed all the meat. Only the bones on the blanket remained to be snatched up by children, sent by their mothers. Guests ate with their hands, picking up a little more corn or manioc from the blanket with a pinch of salt. At this point, women stored what they could not eat in plastic bags they brought for this purpose. The Quechua term "ĉani" refers to the food and drink the hosts expect their guests to take home from the feast. Some women came prepared with large sacks for extra mote and manioc, which the bride's father offered to everyone, as guests must eat all the food. 
The men who had been helping serve the food now collected the bowls from the guests and buckets from the blanket. They shook out the blanket and white cloth, and a senior man said a closing prayer, which people responded to with a unified "Thanks!" Now the bride's father and his helpers offered the guests cups of guarapo and small servings of yonque from communal glasses. Several bottles of yonque rotated around the room.

Someone turned the music on again, and dancing continued until dawn. The next day, the groom's parents hosted another, smaller feast. At a later time, the couple may be legally married through a church or civil service, but given the remote location of Kañaris, this is uncommon. In the eyes of community members, they have already legitimized their union through a traditional marriage contract. The young man and woman now work towards building their own home, cultivating their fields, and raising children.

\section{Becoming established in Kañaris}

A couple of weeks after my arrival, I moved from Mercedes' house to stay with Andrés and Isabel. This offered me the great advantage of being able to learn about the daily activities and concerns of a typical household. Like Mercedes, Andrés was trained as a schoolteacher, but he did not have a permanent teaching position. Sometimes he found short-term teaching contracts in other communities in the district, but for most of the year he stayed with his family and tended his fields outside the town.

Andrés was one of those exceptional individuals who knows about how things are in his society, asks why things are the way they are, and is willing to share that 
knowledge with an outsider. He taught me many things about local customs, the history of the district, what matters to people in the community, and the political issues at stake. He introduced me to numerous people, brought me to talk with various healing specialists, and, I am sure, vouched for my intentions in the community only to complete my university studies, without any sinister connection to a government body or foreign company. Townspeople also regarded Andrés as a cultural authority. For example, he had succeeded his father as the leader of the Bell Dancers (Danza de Cascabeles), schoolteachers consulted him when they wanted students to enact a dramatic performance of a traditional wedding, and people always gave him a public audience when he wanted to talk about cultural or political matters during community events.

Andrés and Isabel lived on the street down from Mercedes' house with their three daughters, aged 7, 12, and 14. As I was a woman rather than a man, Andrés consented to me spending extended periods of time in his home with his wife and young daughters. $\mathrm{He}$ rented to me a second storey room where the family kept their corn. When I was away from town, they would offer this room to teachers and other visitors passing through for a night or two. Although Andrés and Isabel were hospitable to any visitor, they were cautious about permitting longer stays because of the potential threat posed to their young daughters.

Andrés and Isabel were in fact only about five years older than I. However, I had neither a husband nor a child, and was therefore not quite an adult in local understanding. In addition, I arrived with only rudimentary language skills and cultural competency. So they became like older siblings who took on a parenting role for me, a common enough family dynamic in this area. 
I was very fortunate to have been welcomed into the home of this generous and caring family. I spent many hours sitting at the kitchen table, a steaming bowl of soup in front of me, talking with Isabel, watching the girls tease one another, and listening to Andrés tell stories by the warmth of the fire. Isabel allowed me to accompany her to the fields and follow her around in household tasks. She taught me what is needed to turn hard and dry corn into boiled mote, how to put on a woman's dress, and how to weave a woman's belt. From Isabel, I learned about the real and present concerns of a woman in Kañaris, her typical life trajectory, her possible dreams and disappointments, and the ways in which she is constrained and the ways in which she may act. She never tired of my persistent questions, photographs, and voice recordings. Isabel took me to visit her mother and sister in a nearby hamlet, to the Mother's Club that the nuns hosted on Sunday afternoons at the convent, and around the town on festival days.

Her daughters were always ready to provide an answer to a question, take me to visit their mother in the field, or teach me Quechua phrases. We would periodically read Spanish books out loud together at night, pirated copies of translated children's stories I brought from Lima or Chiclayo: Charlie and the Chocolate Factory, Harry Potter and the Philosopher's Stone, and The Diary of Anne Frank. “Remember when the wicked child was thrown away by the squirrels because she was a bad nut?" the middle girl asked me months later. And, "What happened to Charlie after he rode in the glass elevator?"

Andrés had six brothers and sisters, all but one of whom were married and lived in Kañaris. The remaining sister lived by herself in Chiclayo. His brother had a house on one side of the town plaza. Two sisters lived on the same street as Andrés, and the two other sisters lived next door to their elderly parents, don Leonardo and doña Sofía. Their 
house was on the northern edge of town, beside a large and quiet field surrounding the school.

\section{The spatial organization of the house}

The first time I was invited into Andrés and Isabel's home, I sat at a table in the front room and talked with Andrés. Isabel came in from a back room and brought me a bowl of soup, but after shyly greeting me, she returned to a part of the house that was hidden by a door. When Andrés showed me the second-storey room with the bed I would use, I did not enter from the staircase behind this door that the family uses. Instead, I climbed a ladder he set up outside of the house, entering the room through an external door on a small balcony facing the street. It was only after several days that Isabel invited me to eat with the family in the kitchen, and it was many months before I began to use the staircase to the second storey inside the house.

Like all the houses I visited in Kañaris, Andrés and Isabel's home was constructed with distinctly "public" and "private" spaces. They had a front room to greet and entertain visitors, two smaller back rooms for sleeping and storage, and a kitchen detached from the main house. Older homes and those in outlying hamlets have a similar structure, although the rooms are oriented in a horizontal row, instead of vertically with access to the street through the front room. All the houses I saw in Kañaris had wooden doors at the front and back that could be locked. The front room usually has one or two windows, protected with either wooden shutters or glass, iron grates, and inside curtains. The overall impression is that the house is intended to keep family members and belongings safe from curious eyes, uninvited guests, and trespassers. 
Houses in the town face the public domain of the street. The front room is an individualized extension of this space. This is where householders greet visitors and host family celebrations. It can also be used to offer out-of-town visitors a place to sleep, for women to weave in rainy weather, and for men to drink yonque on Sunday afternoons. It usually has a couple of low benches or chairs and a table. Some of the front rooms I visited included a television or compact disc player, while other families kept these valuable goods hidden in a back room. The front room usually has a curtain or wooden door that leads to the family's more private spaces at the back of the house.

For example, in Andrés and Isabel's house, behind the door of the front room there was a hallway with the stairs to the second storey, the bedroom, the storage room, and the kitchen. Like the rest of the house, the kitchen was made of unplastered adobe bricks, with a packed earth floor, a corrugated tin roof, and a bare light bulb hanging from a rafter. I visited some homes in outlying hamlets that still had roofs made from woven grass, but this is increasingly uncommon. Woven roofs provide insulation, but tin roofs are more waterproof and free of rats.

Andrés and Isabel's kitchen was just big enough for the cooking hearth, a small table with two benches, and a narrow shelf of dishes. Some of the kitchens I visited in town - such as those of storeowners - had propane stoves instead of wood-burning ones. Women told me that propane stoves are costly but save them the work of hauling firewood from the mountains. Other women noted that propane stoves do not provide heat, and food cooked on them is less tasty (even though the smoke from the open hearth sometimes bothers them). The brick or stone hearth is always constructed below waist 
level, so that a woman can cook while perched on a small stool or sitting on the folds of her long wool skirt upon the ground.

The kitchen is the most private but still social part of the house. Bedrooms are perhaps more intimate spaces, but it is very rare for a visitor to enter one, unless the room serves another purpose during the day. While the front room is the space where guests are received, the kitchen is where family members talk. It can be considered the heart of the household. This is so not only for practical reasons - it is the interior space where family members will most often gather together to cook, eat, and talk - but because only family members and trusted, well-known visitors will be invited to enter. A person who has moved from visiting in the front room to the kitchen is effectively drawn into a closer relationship with the members of the household.

The kitchens I visited always had a wooden door to keep guinea pigs in, and chickens and dogs out. Households almost always have four or five fat guinea pigs squeaking and running around. They keep warm by the wood-burning hearth, and they eat vegetable scraps and grasses tossed on the floor. Isabel kept her kitchen tidy by sweeping it every day, and her guinea pigs safe from wild animals such as weasels by shutting them into a closet at night.

Behind the kitchen, Andrés and Isabel had a back yard with a woven cane fence. Their home was very comfortable, as the yard included two water taps (which brought untreated water from the municipal line), an enclosed shower, a dry latrine, an open wood shed, and a cane chicken coop. Households that lack basic water and sanitation have to use the taps, showers, and toilets of their neighbours or relatives. 
The back yard functions as an extension of the household's private space. This is where family members bathe, wash clothes and dishes, butcher animals, and prepare large meals. In the afternoons, women weave and children play. It is common for houses in the town to have a fence, which keeps animals such as chickens and ducks in, and passers-by out. If there is room, the family may also have a small household garden with culinary and medicinal herbs.

The public and private areas of the house (and by extension, the town) are also practically and discursively gendered. While the public street is a space dominated by men, the privacy of the home is the domain of women. Within the house, the front room is the space most associated with men, where men gather and visit when at home. The kitchen is closely associated with women, where women work and occasionally visit, sometimes simply talking over the walls to her closest neighbour. As throughout the Andes, the kitchen is the pre-eminently female space, where women undertake the highly gendered (and esteemed) work of cooking and serving food, a primary mode through which their authority and power is acknowledged and enacted (see Sax 2011: 62-63, 77; Weismantel 1988: 177-181).

In Kañaris, furthermore, the front room of the house is explicitly gendered and named as male, while the kitchen is gendered and named as female. This is made apparent during the "house baptism" that is traditionally undertaken to bless a newly constructed home, which we will return to in Chapter 5. In this blessing, the "male" part of the house is named after a male saint, and the "female" kitchen is named after a female saint. For example, Andrés and Isabel's house (which was constructed in the mid-1990s) was named after San Juan and the Virgen de la Merced. Andrés said that if you fail to 
baptize your house, the Devil will "win" it. However, people nowadays say that the ritual costs too much money, and I did not hear of any house baptisms being performed when new homes were built during the time I spent in Kañaris.

The spatial organization of the house sets the tone for the general front-back and public-private orientation of household activities and cultural dispositions. From this perspective, a distinctly Kañarense "habitus" is reflected and reproduced in the organization of space and social activity (see Bourdieu 1990: 52-65, 271-283). Physical movement from the street to the home, and from the front towards the back of the house, corresponds to increasingly private and intimate spaces. In addition, private activities and knowledge are contained within the enclosed spaces of the home. In a small town in which neighbours can easily talk and listen over walls, and in which one can be sure to be unseen or undisturbed only when enclosed in houses, this privacy is valuable to carry out daily tasks and relax.

But it is also valuable because of local notions of secrecy that are necessary to mitigate vulnerability to gossip and the uncertain trustworthiness of others. Whenever people wanted to tell me about matters that they wanted to keep secret, such as marital infidelity or consultations with sorcerers, they would do so in fields when no one else was around, or in hushed tones behind closed doors. The cultural habit of keeping certain things hidden extends to public spaces as well, in which people will keep valuables such as money and food out of public view by tucking them away deep in the folds of clothing, or stowing them behind ponchos and within cloth carrying shawls. People will also turn their back to others to obscure an action, talk in low tones so that only their intended 
audience may hear them, and navigate conversations so as to not reveal information they do not want to share with their interlocutors.

\section{The household as the basic social and economic unit}

The traditional marriage ceremony we saw at the beginning of this chapter forms a new household, with a nuclear family. By foregrounding the household as the primary unit of social reproduction and economic production, I follow the work of Andeanists Olivia Harris and Mary Weismantel (see Harris 1978: 21-22, 28-32; Weismantel 1988: 29-32). As both these anthropologists recognize, there are limits to the heuristic framing

of Andean society as comprised of a collection of discrete social and economic household units (see especially Harris 1978: 32-34).

For example, a young couple's household is socially related to those of their parents, and by extension their familial lineages. It is also connected to their godparents, who helped create their household in the marriage ceremony. Young couples often live with the husband or wife's parents for several years, until they are able to build their own house. Elderly couples ideally live with one of their grown children, who take on the most work intensive tasks in their household. For example, one of Andrés' married sisters lived with their parents. She helped her mother with cooking and washing, and her husband worked in her father's fields.

Grown siblings and parents living in separate houses regularly provide one another with food, childcare, and work in their fields. As well, children can freely move among the households of grown siblings or close cousins. For example, two of Isabel's nieces, aged 4 and 6 , often came by her kitchen for an extra bowl of soup, particularly 
when they did not want to go to school. From one perspective, a child is "raised" not just by his or her parents, but also by the adult family members closest to his or her father and mother.

In addition, is possible for other people to become members of one's household. Anyone who lives under the same roof, eats from the same pot, and contributes to the household's maintenance for an extended period of time will become integrated into the household (see also Weismantel 1988: 169-172). For example, Mercedes informally adopted one of her nieces, and raised the girl from the time she was an infant. When her niece finished school and moved to the city, Mercedes tried to find another niece or nephew to help her around the house, in exchange for food, lodging, and paying the child's school fees. Such adoption is an established practice throughout the Andes, with children sometimes being considered closely related to their adopted parents by virtue of mutual care and longterm cohabitation (see Leinaweaver 2008: chs. 4, 6).

Yet as Weismantel notes, in-laws are "one category of people who eat under the same roof, yet are not really kin" (1988: 171). For example, Isabel lived with her in-laws for the first six years of her marriage. I have always known Andrés' parents to be cordial and generous, but I also understand that a daughter-in-law is typically in a subordinate position in the house of her in-laws (see for example Weismantel 1988: 173-175). From what Isabel told me, she is more comfortable and happy now that she and Andrés have their own house.

As these examples illustrate, there are significant social connections and economic exchanges between households that embed married couples in a network of families. Nevertheless, it is through the household that material wealth is created. Within 
the house, surplus is enjoyed and distributed at the discretion of the producer. For example, a bride and groom each bring their own fields, animals, and other goods into their marriage, and they continue to retain private ownership of these assets even when they are jointly maintained and used. The same logic holds for money acquired from temporary employment, cash cropping, or selling a weaving. This income is the product of a man or woman's individual effort, and can be spent according to his or her priorities and desires. For this reason, I always provided Isabel and Andrés with separate payments for the nights I spent in their home and the times they helped me with specific tasks.

At the same time, the wife and husband both contribute labour and income to support direct family members and maintain the house as a physical space. In this sense, privately held goods and other forms of accumulated wealth are held by the nuclear family - the husband-wife pair and their children - and not their extended kin. From this perspective, the purpose of the nuclear household is to produce food and other forms of value to support people considered to be their children by birth or adoption. To this end, young couples strive to establish households economically independent and spatially distinct from their parents and siblings.

The work of both a man and a woman is necessary to sustain a household. Both women and men work in the fields. Men turn over soil and prepare new fields, provide irrigation if possible, and take on heavy harvesting tasks such as cutting wheat and transporting corn and potatoes. Women sow seeds, weed, and harvest hand-picked crops. Men are also expected to build and maintain the house, while women take care of young children, cook, clean, and collect firewood. It is difficult for a man or woman to carry out all these tasks by themselves, even if they have the help of older children and other 
family members. Husbands and wives who have lost their spouses to death, separation, or abandonment try to remarry as soon as possible. Nevertheless, I observed single women with children to be more vulnerable than men in a similar position. This is because it is the senior man of the household who mediates public relations between the household and the wider community.

Unmarried men and women do not usually form independent households, but instead continue to live with their parents or look for work in the city. Mercedes is the one unmarried and unwidowed person I knew who had her own house. She was able to support herself because she had a stable income as a permanent schoolteacher. However, in her opinion, this was not an ideal life situation. One becomes a complete member of the community only by forming a household in a conjugal relationship and establishing an inter-household network through the various means that this relationship affords. This includes the extension of dependable people to the natal family of one's husband or wife, the formal and informal exchanges of work and food that link the domestic economy of one household to another, ritual offices in which married couples become sponsors of significant community festivals, and the cultural institution of ritual co-parentage or compadrazgo that surrounds the lives of children.

The birth of children is key to the establishment of the couple's household as a discrete social and economic entity. The people who I knew in Kañaris desired and valued children in themselves, and indicated a house is empty and lonely without them. But children are also one of the reasons for a nuclear family's existence. A couple living together in a separate building is not a complete household until they have children, and the permanency of their relationship is tenuous until at least one child has been born. 
There is no social stigma attached to the separation of a couple that does not have children, and men and women can remarry even if they already have children. On the other hand, a husband and wife who have several children are unlikely to separate.

From a functionalist perspective, children enable married adults to interact in culturally institutionalized ways. A couple widens the network of people with whom they can exchange agricultural products, labour, resources, and general goodwill through inter-household ties in part mediated through children. Such ties are formally established through the life-long relationship of compadrazgo. If one couple agrees to become another couple's co-parents for a specific event, they are expected to provide a gift for the child, such as a sheep, a set of clothing, or money. In turn, the child's parents are expected to help out their co-parents at undetermined times in the future, for example by periodically working in their fields, or providing gifts of agricultural products. When the child is old enough, he or she may also take on this role. This is a local variation of the widespread practice of "fictive kinship" throughout the Andean cultural area and Latin America. Compadres widen a couple's pool of reliable work partners and political allies beyond their natal families. They can be drawn from extended family members, such as an aunt and uncle, which strengthens the relationship within the lineage. Or they can be community outsiders - such as Lupe and Nicolás, "white" schoolteachers - by which a couple builds a strategic connection to people they hope will help themselves and their children to access work, education, and other resources (see also Gudeman 1971: 45).

Couples can also seek co-parents for other occasions, such as school graduation, the construction of a new home, and the opening of a business. These ties forge relationships of obligation, reciprocity, and affiliation between households and familial 
lineages. It is these multi-layered connections that form the community - or ayllu - of Kañaris in practical terms.

\section{The household economy}

I would meet Isabel in the kitchen for breakfast in the morning. She had already been up since at least six o'clock, taking her four sheep to pasture and checking on her three cows. Either Isabel or her eldest daughter cooked breakfast as the two younger girls got ready to leave for school at seven-thirty. The older daughter was in secondary school and had classes in the afternoon.

The dishes Isabel cooked were based around the corn, beans, wheat, and potatoes she and Andrés produced, supplemented by eggs from her chickens, fresh cheese from her cows, limes and hot peppers from the family's orchards, and herbs she gathered. When in season, the family also ate fruits such as oranges and bananas, vegetables such as squash, and legumes such as peas. Occasionally she received barley, quinoa, manioc, and other high-altitude tubers from her extended family and neighbours. On festive occasions she would butcher one of her guinea pigs, or buy fresh chicken or canned tuna. She also regularly purchased rice, cooking oil, salt, sugar, packaged noodles, small amounts of vegetables such as carrots and tomato, instant coffee, and palm-sized breads from the little stores in town. Like all families in town, Isabel received a monthly package of enriched oatmeal and evaporated milk, which were provided by the central government through the "Glass of Milk" nutritional program for the very poorest in Peru. Sometimes she made this into a thick morning drink. Other people considered the oatmeal very unappealing food, and used it as pig feed. 
Isabel and Andrés had several small fields scattered throughout the area surrounding the town. They cultivated some of these parcels of land - less than one hectare each - and left others as animal pasture and sources of firewood. Although Andrés and Isabel worked several of these fields together, one or the other each owned them, as they had been inherited from their parents. They used the largest and flattest fields for the staple crops of corn, beans, wheat, and potatoes. A low-altitude, sunny orchard produced small amounts of fruits for the family, as well as coffee and passion fruit to sell in the city.

Most people in Kañaris just grow enough to support their families throughout the year. In the past five years or so, some people have begun growing coffee and passion fruit as a cash crop. Several community members told me that the climate has become warmer and drier in the past decade, which has made growing these crops possible. The profit from selling these products to urban marketers is an important source of income for households such as Andrés and Isabel's. They require a significant investment of time, work, and money. For example, Andrés had to buy coffee seedlings, and clear additional land while still sowing subsistence crops. At the beginning of 2011, Andrés had about 350 coffee seedlings protected under a woven canopy waiting to be transplanted with purchased fertilizer. He already had one small field of mature coffee bushes that produced red berries. He had no irrigation canal, and so had to water them by hand. The family periodically picked a bag of coffee beans, using a large stone to crush the fruity skin off the core, which they dried in the sun. Andrés then took these untoasted coffee beans to sell in Pucará. He was familiar with coffee production as he had once worked on a plantation in Tarapoto, close to the Amazonian jungle, where a cousin of his lives. He 
had his own land with papaya, avocado, and coffee, but he lost it for defaulting on communal work party obligations.

Isabel oversaw the passion fruit vines, which she harvested twice a year, in January and July. This was her primary source of income to use at her personal discretion - for example, for weaving supplies, dishes, school supplies, and supplementary foods. She also invested money in additional sheep, pigs, and cows. For example, when one of her smaller calves matures, she will sell it and buy two little ones again. Each harvest, Isabel sold one or two hundred boxes of passion fruit for a profit CAD\$400-1000. Her only other sources of discretionary income came from selling mature animals, spinning wool and weaving ponchos for other women in town, or selling weavings to visitors who occasionally came to Kañaris. Isabel was introduced to passion fruit production through a Peruvian nongovernmental organization, La Solidaridad. The NGO has an office in town and hosts workshops on diversified agricultural production. Unfortunately, they do not help local farmers bring their products to market. Isabel contracted a local truck driver to transport her passion fruit to the coast, and sold them to a cousin in Chiclayo.

Coffee and passion fruit production are the most recent form of income available to people in Kañaris. Andrés told me that in his grandfather's time, men would take donkeys with dried corn to the coast and bring salt back. People need money for many more things than salt nowadays - household articles and tools, school supplies and fees, unanticipated medical expenses. Some have opened small stores in town, or have saved money to buy a transport truck to take products and people to and from the highway at Pucará. Men regularly leave the town for a month or two, working as manual labourers in cities such as Chiclayo on the coast, or on plantations in the jungle, such as Tarapoto. 
Young women also leave the town looking for work before they have children. For example, before Isabel was married, she was a live-in maid for a family in Chiclayo. Parents also send school-aged children to live with relatives in the city, where they perform household chores in exchange for access to school. For example, when Andrés was about ten years old, he worked as a live-in helper for a family in Chiclayo. His father hoped he would receive an education, but he brought him back to Kañaris when he saw the family was mistreating him. Andrés and Isabel's eldest daughter also lived with her aunt in Chiclayo for a year, but she returned to help her mother when Andrés got a teaching job that took him away from the town for months at a time. In 2012, this same daughter worked in Chiclayo during the break in between academic years. She wanted to be able to buy her own weaving supplies and clothes. Perhaps she also wanted to save money to attend college when she graduated high school, as she told me she intended to do.

Some young adults choose to stay in the city, either because they prefer a nonagricultural life, or because they do not have adequate land to farm at home. The people who stay in Kañaris, however, continue to support their families through subsistence agriculture supplemented by short periods of paid employment, or by practicing a trade alongside farming. For example, during the time I spent in the town, there were four family stores, four truck drivers, a carpenter, a welder, and a butcher. Some men periodically worked for wealthier neighbours as day labourers in their fields. A handful of skilled workers and well-connected people worked in the school, medical post, and municipal office. I also met several men who had once worked for the Cañariaco Norte 
mine. However, since involvement in the mine is highly contentious in the town, no one I met explicitly told me they were presently employed there.

\section{The agricultural year}

Community members describe the agricultural year in terms of the "rainy season" (roughly November to April) and the "dry season" (roughly May to October). Unlike in the northern hemisphere, however, different crops are grown and harvested throughout the entire year. In general terms, people prepare fields before the onset of heavy rains, plant and weed throughout the rainy season, and harvest when the rainy season ends.

Andrés and Isabel also planted by the cycles of the moon. The basic idea is that the development of the crop mirrors the increase (waxing) of the moon. According to Andrés, crops will grow whenever they are planted in the moon's cycle, but they will not be as robust. For example, he told me that corn should be planted four to eight days after a new moon, so that they increase alongside the moon. Another time, he said one should plant with a moon of fifteen days or more, so the corn will grow strong and the storage sacks stay full longer. Isabel also told me if one plants with a new moon not yet full, the plants will grow rapidly but without strength, easily knocked over by wind and rain. If one plants with a decreasing (waning) moon, the plants will not grow tall, but will stay close to the ground, producing wider fruits that soon run out. Similarly, one should harvest on a full moon, so that the storage bag stays full like the moon. If one harvests on a waning moon, the bag will empty as the moon decreases.

In September and October, people harvest the last of their corn, beans, and wheat.

Peas are also ready to be picked. Other households are slightly ahead, already planting a 
new crop of corn and beans. Before the fields can be planted, people burn the stalks and stubble to the ground. If the field is small, groups of two to six women use foot ploughs to turn over the soil. In September 2012, Isabel and her sister planted a field using long sticks tipped with a metal point. She made a hole a couple of inches deep in the ground, dropped in a couple of dried corn kernels and beans saved from last year's harvest, and covered it with a little soil, lightly tapping it down. They planted several varieties in the same field, corn and beans together so the bean vines can wind their way up the corn stalks. Sometimes people plant a local squash along with the corn and beans. It is a sensitive vine that will not produce fruits if disturbed, and so is often planted in an area removed from regular foot traffic. Corn and beans can be planted on sharply sloped hillsides, and even in areas that have not been completely cleared of undergrowth. People in Kañaris do not make terraces to create a series of flatter fields (compare for example Gelles 2000; Gose 1994).

Larger fields require plough oxen to prepare them, and this is the work of men. For example, in October 2011, Andrés rented two oxen from one of his neighbours for CAD $\$ 8$ a day. The oxen pulled a long, wooden plough to cut deep furrows into the field Andés had burned. It took him two days to turn over this field. The previous year, he had planted wheat. That year, he planted corn.

People plant potatoes in October, using seed potatoes saved from the previous year. They need to be weeded three times, in November, December, and January. According to Isabel, potatoes have become vulnerable to a disease in the past ten or fifteen years, and so they also need an application of liquid fungicide when the leaves first appear. She does not grow many potatoes now, saying that they are too much work. 
Most other crops are grown without any pesticides or fertilizers. October and November are also times to plant perennial fruit-bearing trees.

In November, people clear new fields by slash-and-burn. Several community members told me that a generation ago, a forest of trees and low shrubs surrounded the town. Now however, because of increasing population, much of the immediate area around the town has been cleared to make way for new fields. Fields cleared in this way can be used for only one or two years, and then must rest for eight to ten. In November 2011, Andrés worked with three or four other men to clear a hillside. They used machetes to hack away at long grass, bushy shrubs, and thin-trunked trees. He let the cuttings dry out for about a week, and then he burned them to the ground. Isabel planted corn and beans in the new field. Andrés cleared this new field for staple crops, making room in more established fields to transplant his coffee seedlings.

Andrés told me that people try to finish planting by All Soul's Day (November 1). When the souls of the deceased return, they walk on the recently sown fields and help them grow. All Soul's Day is an important annual festival in Kañaris. People visit the cemetery and place candles, flowers, and fruit on the gravesites of dead relatives. They pour sugar cane alcohol on the graves while praying for them. Unlike the southern Andes, however, no rituals are performed in the recently planted fields (see for example Gose 1994).

The seasonal rains start in November or December. Some households may still be planting corn and beans. Others are already weeding. As the rains become heavier in January and February, people spend more time indoors, venturing out only for weeding and other essential tasks. Often men and older children go to work on the coast for a 
month or two, where it is the height of summer. It is a difficult time of year to travel, however, since the dirt road leading to the paved highway at Pucará is often washed out.

Once the heavy rains start to subside in March, people can start harvesting potatoes and preparing to plant wheat. In March 2011, I helped two of Andrés' sisters dig out potatoes from a rocky hillside. We put them into large woven sacks, and their husbands loaded them onto a horse's back and walked it to town. I also participated in a work party to help Isabel's mother prepare her large wheat field. A group of four or five women turned over the soil using foot ploughs on the sloped part of the field. Isabel's mother also paid a man to use a pair of oxen to prepare the larger, flat area. As we turned over the soil, she sprinkled wheat kernels saved from the previous harvest into the furrows.

By April, many households are planting wheat. Corn can also be weeded. The first of the corn can be harvested in May. This is called "young corn" (choclo) because it is still green and fresh, instead of dried on the stalk. It can be eaten right away, large starchy kernels, or ground to make seasonal treats called humitas, wrapped and steamed in corn leaves. Most of the corn is left on the stalk to dry, before being picked and stored for the rest of the year. This "mature corn" (maiz) can be toasted and salted, or processed with wood ashes from the kitchen fire and boiled into hominy (mote).

May and June are the primary months for harvesting corn. Peas are also planted. The height of the harvest season is June, marked by the Fiesta de San Juan (June 24) Saint John, the town's patron saint. According to Andrés, corn was the most important crop when he was younger. Nowadays corn has been partially displaced by rice. Since the 
truck road to Kañaris was cleared in the 1990 s, most people eat rice brought in from Pucará at least once a day.

By July, the first wheat is ready for harvest. The wheat, corn, and bean harvest continues into August and September. Most of the wheat cutting and threshing is done by hand. When I arrived during Andrés and Isabel's wheat harvest in September 2011, they ran the hand-cut stalks through a small gas-powered threshing machine rented from a local storeowner. Then Andrés and his brother-in-law used shovels to throw the stalks up into the air. The light wind separated the wheat from the chaff. Isabel and her sister-inlaw next sifted the wheat by hand, pouring a manageable amount from one shallow bowl to another, so that the last of the chaff would blow off on the breeze.

\section{Social and economic relations between households}

When Andrés and Isabel prepared new fields and harvested their wheat, they asked a couple of family members or neighbours to help them. These people knew they could call upon Andrés and Isabel to work for them in turn. People in Kañaris call this "minqa," work for like work with the provision of a midday meal, and it is a local variation of the widespread Andean practice of reciprocal labour exchange (see for example Gose 1994: 7-12).

In Kañaris, minqa is the exchange of agricultural work between specific households, and it is the most common form of cooperative labour. On two occasions I observed people pooling their labour for the benefit of several households at the same time. In the first instance, Andrés and Isabel got together with three or four other families to dig an irrigation canal that would supply water to their adjoining fields. Andrés called 
this minqa, perhaps because a limited number of households were involved, and because different families took turns hosting it by providing the food and drink for the day. However, Andrés told me, some families were more reliable than others, and they did not have sufficient workers to complete the canal.

The second example of communal work Isabel called "faena," an obligatory community work day organized by the Parent's Association of the school to clean up the school grounds. Women used shovels to cut away grass that had grown around the classroom buildings, and men and older boys dug a ditch for a water line to supply the school kitchen. After a couple of hours, the seventy or so people gathered for the meeting of the Parent's Association and a snack of bread and milky oatmeal supplied by the government's "Glass of Milk" nutritional supplement program. One of the proposals passed at the meeting was to fine people CAD $\$ 4$ (approximately a field labourer's day wage) if they failed to participate in the communal work parties.

As these two examples indicate, community members recognize the value of communal labour, but they also find it difficult to persuade people to consistently participate. The social obligation to participate is apparently weaker where the relation between the households is less personal.

Minqa is one example of the ways in which households are socially and economically bound to each other through mutual aid, support, and goodwill. The more closely related one household is to another, the more difficult it is to avoid reciprocating agricultural labour, gifts of food, and invitations to family events. Relation in Kañaris is a result of birth, marriage, and the fictive kinship of compadrazgo. A man or woman is first 
and foremost related to their parents and siblings, then their aunts, uncles, and cousins, next their in-laws, and finally their godparents and co-parents.

These ever-widening spheres of relation are illustrated in the traditional marriage ceremony, which we saw at the beginning of this chapter. The ceremony is important not just because it legitimizes the couple's relationship and the household they will form. It also acknowledges the formation of a series of relationships among the couple, the parents and their family lineages, and the compadres. Through the marriage "contract," a young couple recognizes that they are indebted and obligated to other people. A young couple whose marriage has created reciprocal relationships among their elders is not likely to quickly fall apart. Such marriage entails social obligations not just between the married couple, but among the elders to whom they should defer.

These relationships entail both formal and informal exchanges of agricultural labour and products. For example, a groom's father and godfather should bring sugar cane alcohol and a butchered chicken to the bride's parents when asking for her hand in marriage. The godparents should give the marriage couple a wedding present, such as a set of dishes or pots, to help them set up their house. The young couple is thereafter indebted to their elders, and should periodically do agricultural or other work for their inlaws and godparents. These exchanges materialize their relationships and demonstrate that they are fulfilling their obligations and extending goodwill to one another.

Formal gifts are presented during major life-cycle rituals, such as marriage, baptism, or a child's first hair cutting. There are also numerous informal, everyday exchanges between individuals and households. A sister, niece, or grandchild who drops by will be offered a bowl of soup or piece of fruit. A cousin who lives next door will send 
over a bowl of fresh potatoes or other high-altitude tubers. Men who visit on Sundays will buy one another rounds of yonqe, sugar cane alcohol. A boy who receives a plate of fried chicken at a festival will share it with his younger sisters. A mother will give her daughter a sheep or chicken to raise as her own. A husband whose brother-in-law helped with his harvest will send him a bag of wheat.

These spontaneous gifts set in motion an action of reciprocal generosity. Informal gift giving is not calculated by repayment, but rather by the logic that the recipient is obligated to extend the same sort of goodwill at an undetermined time in the future. Gifting creates debt, and although gifts should be returned by reciprocal gifting (Mauss 1966: 10-12, 71), debt in the Andes debt should not be definitively cancelled, for it acknowledges and renews an ongoing relationship between equals (see Gose 1994: 8-11).

People also give gifts out of charity. For example, Isabel had a poor aunt who lived across the street. She periodically sent her a plate of food, and allowed her to regularly use her family's latrine and water tap. Another type of gifting is undertaken by couples who sponsor major household festivals. For example, Isabel's cousins who lived next door hosted a hair cutting ceremony for their two-year-old son. The parents provided all the things necessary for a good party: A meal with soup, boiled corn and manioc, and roasted sheep; plenty of yonqe and guarapo; and an electric sound system to play music and dance all night long. The cost of such an event could amount to an entire year's savings. While the parents named a specific couple as their compadres for the ceremony, people said all the guests who came and cut a lock of the child's hair were also coparents. After I attended the ceremony, the boy's mother often invited me over to visit and eat supper. Before I left Kañaris, I bought both of her young sons a set of clothing, a 
culturally appropriate gift I was able to give without the risk of displaying favouritism because we were co-parents.

Community festivals are another instance of the inter-household redistribution of wealth. For example, each year two couples are named to sponsor the Fiesta de San Juan. One couple sponsors Saint John (San Juan), and the other couple sponsors his local counterpart, Saint John of the Little Water (San Juan de Aguita). Both couples provide food, drink, and music for a public meal, and new clothes for the statue of the saint. They arrange the mass, procession, and all other activities for the three-day festival.

This is one of the community festivals that comprise the system of traditional offices, or "cargos," by which a mature couple gains public prestige and demonstrates their respectability and success. According to Andrés, a generation ago there were many such festivals that needed to be sponsored throughout the year. Today, people in Kañaris sponsor the festival of the Reyes Magos (January 6), Cruz de Mayo (May), San Juan (June 24), Santa Rosa de Lima (August 30), and the Virgen Inmaculada (December 8).

These festivals are important community events in which private wealth is publically redistributed, and saints bless the sponsors and community in general. But they are also significant because they bring community members together for a common celebration and veneration. When people gather for community and household rituals, this strengthens individual and inter-household relationships. They are also opportunities to create goodwill in the community, which is necessary to counteract the suspicion of malicious sorcery. 


\section{Chapter conclusion}

In terms of daily life, the community of Kañaris is made up of families and households connected to one another through birth, marriage, ritual kinship, common residence, shared work, and the myriad forms of formal and informal gift exchanges that take place throughout the year. Individual households produce foods and other forms of value by which married and co-habiting couples support their children. The gendering of household spaces reflects the sexual division of labour that makes the household economy possible. The distinction between male and female domains and activities is carried through to public areas and community events, where men socialize directly more often with men, and women more often with women. Nevertheless, the husband-wife pair is the social unit by which households interact with one another through practices such as compadrazgo and festival sponsorship.

The spatial organization of the house, with its distinction between public and private spaces, corresponds to experiences that are appropriate to share with people with whom one has different degrees of familiarity. For example, the front room is for greeting and entertaining guests, while the back kitchen and yard is where family and close friends visit.

Immediate family members should be the most trustworthy and reliable people. In my observation, people in Kañaris are most likely to have the closest relationships to their birth family and the households they form as adults. It is parents, grandparents, siblings, and first aunts, uncles, and cousins with whom one interacts on a daily basis. These are the first people one looks to for playmates, childcare, work partners, and to simply visit and relax. Children may spend their free time in the households of both their 
mother and father's direct family members. As adults, men and women often continue to spend more time with their parents and siblings than their in-laws. Work partners and close friends are typically one's own siblings or immediate cousins.

One should ideally be on good terms with more distantly related kin and other community members, but these people are not typically entrusted with sensitive information about the household or individual family members. Thus while all community members are related under the ayllu of Kañaris, and while almost everyone in town is a cousin of one sort or another, the distinction between "insiders" and "outsiders" that we saw in the previous two chapters is implicitly reproduced on an individual level.

For example, a woman will work with her husband to maintain their household, and a man will exchange agricultural labour with his in-laws and co-parents, but that does not mean they consider their interlocutors worthy of the most intimate, secret, and potentially damaging personal information. Were private knowledge made publicly known, this could make one vulnerable to gossip and ill-will. In addition, it is one's own extended family members, work partners, and neighbours who can potentially do malicious sorcery to harm oneself. In a small town in which everyone knows the business of everyone else, and in which being trusting makes one vulnerable to interpersonal attack, personal information and private knowledge are carefully guarded.

The house is constructed to protect people and their belongings from individuals outside of the household and natal family. Similarly, there are social practices by which people manage the uncertain trustworthiness of others, and mitigate their vulnerability to both human and non-human agents. In the following two chapters, we explore these 
themes in greater detail, by outlining the local contours of trust, secrecy, and vulnerability. 


\section{Chapter 4: Trust and Secrecy}

One night, Andrés told his girls a story after dinner. He often recounted fables heard from his parents and grandparents when he was younger, and from what I could see, he enjoyed painting a verbal picture with all the correct details. Luckily I had the presence of mind to turn on my voice recorder. ${ }^{10}$ We were all seated around the small kitchen table, with Isabel tending the fire in the corner, drinking our evening tea in the quiet darkness of the coming night.

"There's a story about a little bird called the waychaw," Andrés began. "The waychaw and the fox, the atoq. In the stories, the fox is always the loser, and very naughty. The waychaw whistles: "Whiiissshhhaaaa." It is very fine, and pretty."

The fox was walking about the countryside, and he came upon the waychaw. "Hi cousin!" said the fox. "Geez, your whistle is pretty!"

"So it is," said the waychaw. "This is the gift the Creator left me. All the girls chase me because of it." And the little waychaw started to whistle luxuriously.

"My dear little cousin," said the fox. "I don't have any luck with love. I have such bad luck that the girls don't follow me. If I could whistle, I believe I could get one. Hey cousin, teach me to whistle."

\footnotetext{
${ }^{10}$ I have taken some liberties with the transcription, favouring the spirit of certain phrases the over direct translation from the original Spanish. I have also condensed certain passages for the sake of brevity.
} 
"But you're four-legged, how will I teach you?" the waychaw replied. "I'm twolegged. This gift was left only for me."

"I can't sing sweet songs like you," said the fox.

"You can't whistle like me. I'm a bird, I have a beak. You have a mouth. You have teeth, I don't have teeth. So that's the difference."

"But I want to learn! I know that you can help me," said the fox.

The fox continued to insist until the waychaw said, "Enough! My old grandparents told me not to teach you."

"But why?" said the fox. "Your grandparents are liars."

"My elders told me that if I teach someone, I'll lose the gift."

"No, that's a lie, you can teach me." And like that the fox, the atoq, convinced the waychaw.

"Since you insist so, I'll help you," said the waychaw. "But it's going to hurt."

"It doesn't matter, I can take it!" said the fox. "What do you need to do it?"

"Bring me a reed, a thick needle, and thread."

The fox went to find the reed, the needle, and the thread. "Hey cousin!" the fox said to the little waychaw. "I've brought you everything you asked for."

"Very well," said the waychaw. "I'll do what you want. But remember you've promised to withstand the pain."

"Yes, whatever it is," said the fox. And so the waychaw started to cut the reed, and he sewed it into the fox's mouth. "AYYA YAOW!" cried the fox.

"You can take it," said the waychaw. The fox cried from the pain, but finally the waychaw finished. 
"Now try to whistle," said the waychaw. And the fox blew, but he couldn't.

"Let's see, how do you whistle?" said the fox.

“Whiiissshhhaaaa."

The fox tried again. "Whi-whi-whi-whi." Like that he started to whistle. The fox was really happy. He ran over the hills, whistling from one to another. He spotted a girl and whistled to her. "Whiiissshhaaaa." And the girl noticed him.

But now, the waychaw had forgotten how to whistle. He couldn't make a soundhe was mute.

The fox continued whistling through the hillsides. That's how the chakwa, the partridge, found him. "Hey!" said the partridge. "What a whistle you have, just like my cousin the waychaw."

"That's how it is. Unfortunately your cousin has forgotten, and passed all his gift on to me."

So the chakwa flew off to find the waychaw. "Hi, cousin," he said, "Why are you so sad?"

"Oh, dear brother! Look at what that fox did to me," said the waychaw. "The fox insisted that I teach him. I sewed the reeds in his mouth, and he started to whistle. Now I can't, I've lost my gift."

“Why did you teach him? Don't you remember what your grandparents said, not to teach anyone? When you teach, you lose the gift."

"It's true, but I've already lost it," said the waychaw. "What can I do now? We're birds, we're two-legged, we have our beaks, we can help one another." 
"See here," said the partridge. "You're my cousin. I'm going to help you. I'm going to destroy that fox's beak. He doesn't belong to us, he isn't part of our family! He's a fox, and he should call the black bear 'cousin,' but not us!'

And the chakwa flew off to find the fox. He snuck up slowly, hiding in the bushes. When the fox walked by, the partridge jumped up - Chaaaaa! Chak! Chak! Chak! - he started to fly.

The fox was startled - Blaaam! - the reed in his mouth tore apart with his tremendous fright. "Wretched chakwa, I'm going to eat you!" cried the fox as the partridge flew out of sight. But the damage was already done.

And like that, the waychaw recovered his whistle. "Thank you so very much," he said to the partridge.

"We're a family of birds," said the chakwa. "We have to help one another, we're family."

“That's why the elders said you shouldn't teach your fellows, because they'll take away your gift," Andrés said. "Things were really sensitive back then. In school, for example, there are some who learn quickly and others who don't. Sometimes they copy over your shoulder. That's why parents said, ‘Don’t let someone copy from you because you'll lose the gift, and it can happen to you like with the waychaw and the atoq.' "'

\section{Trust and trustworthiness}

The story about the little bird and the fox is a moral fable. The waychaw was divinely bestowed with a unique gift. His elders had warned him not to teach anyone this 
secret, and when he did, he lost it. The fox had tricked him. The fox did not care about the consequences this could have for the waychaw; he was only interested in his personal gain. The waychaw recovered his whistle with the help of the partridge, a member of his family. In my reading, the lesson in this tale is three-fold: you should listen to your elders rather than manipulative outsiders, you should not share secrets with untrustworthy individuals, and family members should help one another.

Yet Andrés ended the tale by reiterating that sharing private knowledge with other people would "take away your gift." I did not immediately understand this connection. Why should it matter if you show someone how to do something? How would this compromise your ability, or the efficacy of applying your knowledge? I now understand Andrés' comment to indicate an implicit cultural logic: If private knowledge becomes publically known, this can make you vulnerable to outside forces. The "outsider" here could be a member of another household or familial lineage, a foreigner from another community, or a non-human entity.

Community members recognize that some people have particular aptitudes, abilities, and skills that others do not have. Some skills can be deliberately learned, such as reading and writing, or knowing when to plant and when to harvest. Other times, an individual must also have an innate aptitude. Not everyone has a knack for playing a musical instrument, spinning wool, or telling stories. These things can be learned, and must be practiced, but it will be easier if an individual already has a "natural talent" for the particular skill.

In some cases, people cannot become competent practitioners even if they want to. For example, any woman can learn how to make herbal remedies, but only those with 
a particular "gift" are able to diagnose and treat illness by "cleansing with guinea pig." These healing specialists, called remedieras, rub a guinea pig over the client's body, open it up to inspect the inner organs, and then prepare an herbal remedy based on this diagnosis. If the woman is "makipaq," with a capable hand, the illness of the client will be reflected in internal state of the guinea pig, and so she can make a proper diagnosis and herbal treatment. If the woman is not "makipaq," the animal cannot effectively be used "like an x-ray" to determine what is afflicting the client. The client will not be cured, and may even become more ill if treated by a woman who does not possess this innate ability.

Some knowledge is not only specialized, but also sacred. The most obvious example of this is knowledge related to sorcery (as both healing and witchcraft). Only sorcerers communicate with the place-based spirits called encantos, and only his apprentice will learn the details of how he does this. If lay people knew how to communicate with the encantos, the mediating role of the sorcerer would not be necessary. But not just anyone can become a sorcerer's apprentice. One individual may want to learn about sorcery but lack the ability to "vision." Another individual may resist a "calling" to sorcery until he is compelled by debilitating illness or the near-death of a close family member. Both sorcerers and remedieras have specialized knowledge, but they also have an inherent ability, aptitude, or "gift" to practice their craft.

Andrés' lesson in the story was that one should not disclose or share one's unique knowledge, lest one loses the unlearned ability or "gift" to effectively apply that knowledge. This becomes more understandable in light of the general cultural disposition of Kañarenses to reserve private activities and knowledge for private spaces, and 
maintain a distinction between trustworthy insiders and threatening outsiders and foreigners.

From the perspective of specialists such as sorcerers, it is important to keep certain knowledge secret because both its esotericism and exclusivity add to the efficacy of its application in causing and curing illness. Most people in Kañaris are not specialists. Even if they have particular knowledge, it is not hidden from non-initiated people. For example, any self-motivated person can learn about the finer points of weaving or herbalism, and they do not have to have a divinely appointed "gift."

Yet people are cautious about sharing this everyday knowledge, especially with those outside the family. Moreover, their caution is not limited to skill-based knowledge with a definable application. People are even more cautious about sharing personal information - information that is directly related to an individual's present actions and plans for the near future. This could include the details of a household's economic hardships, triumphs, or plans for improvement; specific facts about an illness or series of misfortunes; opinions regarding the prospective mining operation; and private feelings about one's neighbour, family member, or spouse.

Why is it important to keep such private information secret? Because the "true" intentions of another person are always hidden. You do not know who to trust, and placing trust in untrustworthy people makes you vulnerable. People in Kañaris are not concerned with privacy and secrecy just for their own sake. They are concerned with the indeterminate trustworthiness of others, and in particular, those who "should" be most trustworthy: family, neighbours, work partners, and fellow community members. 


\section{Honesty, reliability, competency, and discretion}

In the previous chapter, I argued that the spatial organization of the house corresponded to different degrees of familiarity between household members and guests. Familiarity and trustworthiness are two key qualities by which householders evaluate what social spaces are appropriate to invite guests into. For example, family members visit with people with whom they are familiar in the front room. Guests can be extended family members, and individuals known to the hosts for many years. Yet this does not mean people will automatically invite them into the heart of the household in the kitchen. While people tend to have more confidence in fellow community members than recent acquaintances, this mutual knowledge and amicability is distinct from trust.

In Kañaris, trustworthy people are honest, reliable, and competent. British philosopher Katherine Hawley also identifies these qualities as key aspects of trust (2012: 4-8, passim). In my observation, people point to the issue of competence when discussing sorcerers. Does a sorcerer have genuine knowledge and skill, or is he a fake? If someone posing as a sorcerer is not really competent to practice sorcery (as either healing or witchcraft), he is fundamentally being dishonest. He is cheating his clients and betraying their trust, proposing to help them when he is only taking their money. In the worst-case scenario, people told me, a sorcerer could be maliciously deceitful, saying he is healing a client when he is actually doing witcheraft to harm them.

In terms of the day-to-day interactions I observed, the reliability and honesty of social others is more important to people in Kañaris. I understood people to frame this in terms of another's intentions: Will my husband follow through on his commitment to provide for our children, or will he abandon us and take up with another woman? Will 
my minqa work partner really work a day in my field, or will he try to get me to work for him without providing anything in return? Is my neighbour really extending goodwill, or is she spreading harmful lies behind my back? Each relationship and social situation brings a different expectation, demonstration, and evaluation of trustworthiness. But because we can never know another's true intentions, there is always a degree of uncertainty in our assessment of their trustworthiness or untrustworthiness.

For example, someone stole clothing and blankets from Andrés and Isabel's house when they had freely given room and board to visitors who came to the town for a major festival. Visitors do not specifically promise not to steal from their hosts, but this is a clear violation of an unarticulated yet widely understood cultural norm. Although an explicit commitment for visitors and hosts to not take advantage of one another had not been made, Andrés and Isabel were justified in feeling betrayed by the unidentified thief or thieves (see also Hawley 2012: 6, 47-48). They continue to open up their doors to numerous visitors during major town events, but they are not so trusting as they once were, and now keep valuables locked behind closed doors.

Community members pointed to an additional factor when they told me about their problems in discerning who is trustworthy from who is not. Trustworthy people must also exercise discretion and confidentiality. In one sense, this demonstrates that there are different levels and different kinds of trustworthiness, as Hawley acknowledges (2012: 54-57). More to the point, loyalty and the ability to reliably and honestly maintain confidentiality are important for the most intimate forms of interpersonal trust - that is, close friendships. Truly trustworthy people can be relied upon to keep private information safe from public knowledge. Gossiping can result in harmful consequences 
even if an individual who has broken confidence by imprudently sharing one's personal information with others does not intend to do so. Other times, people can deliberately make use of private information for their personal benefit at the expense of another.

For example, someone was stealing Andrés's coffee seedlings, and this person clearly knew what he or she was doing and whom they belonged to. So Andrés had to move his unplanted seedlings from his primary field to a more secluded and secretive location to protect his investment from the self-interest and envy of other community members.

As we saw in the discussion of the house, this tendency towards secrecy is a predisposition that is unconsciously reproduced at different levels of everyday life. Secrecy and discretion are also part of a general disposition or characteristic "habitus" (Bourdieu 1990) that is sometimes habitually and other times deliberately enacted by community members. Urbanites on the coast who have heard of Kañaris consider people there to be highly reserved, closed, and even hostile to visitors. An acquaintance told me that this area is considered the dangerous back-woods region beyond Incahuasi. This was not really my experience, even though people are reserved about talking and interacting with strangers. As we saw in Chapter 1, this is about the local perception that foreigners are threatening, rather than the deliberately malicious intentions of locals.

Still, in daily interactions amongst themselves, people in Kañaris are highly cautious about confiding in others. I observed this not just in terms of how people approached and conversed with me, but also in what people disclosed to one another about sensitive topics, such as their political allegiances and marital relations. On one hand, people do not freely talk about personal affairs because some topics are not other 
people's business. But community members are also secretive because they often do not know whom they can trust with their private information, and this can expose their vulnerabilities for others to see. As Hawley says,

Trusting is the right thing to do when it aligns with or generates trustworthiness, while trusting the untrustworthy is a recipe for betrayal, disappointment, and exploitation. Trust can also misfire when we misunderstand the interests and commitments of others, even though they are not inherently untrustworthy. (Hawley 2012: 110)

In Kañaris, sharing private knowledge with untrustworthy individuals can make one vulnerable to harmful gossip and envy, to betrayal and deceit, and to illness, misfortune, and malicious sorcery. Therefore, whenever placing trust in someone - for example, to follow through on commitments, to not imprudently divulge private information, or to be acting out of goodwill and not deceit - people have to evaluate the trustworthiness of the individual in relation to the present situation. Although the "default" position is one of trusting fellow community members (as it seems it must be in order for any society to function), people evaluate their fellows in terms of what they have observed them to do in the past, and what they think it is likely they will do in the future. Mature people realize that individuals can be trustworthy in some matters and not others, that the appearance of goodwill may not always be what it seems, and that an individual's future actions can have detrimental outcomes for oneself, whether intentional or not. I observed community members to demonstrate discernment and "thoughtful reflection" (Gadamer 2004: 319) in their interactions with both me and their fellows, indicating what Aristotelian philosophers recognize as a type of practical knowledge or 
reasoning in their context-specific evaluations of another's trustworthiness (Gadamer 2004: 318-319; MacIntyre 2007: 161-162; see also Aristotle 2004: 150ff).

\section{Knowledge of healing and weaving}

I learned about this practical discernment in Kañaris throughout the development of my relationship with doña Beatriz. She was a quiet and dignified woman of about fifty years, and the wife of don Gabriel, who was a teacher at the school and the musician for the men's dance troupe, the Bell Dancers. In addition, she was a well-known weaver in town, and one of the few women who continue to weave pure sheep's wool that is spun by hand and dyed using local plants. She was also an adept herbalist (remediera), able to make complex herbal remedies for common, non-life-threatening illnesses. She told me she used to also do "cleansing with guinea pig," but stopped this practice when the nuns told her it was "bad."

Doña Beatriz was one of the first women I started visiting to ask questions about spinning and weaving. I bought several shawls from her, a belt woven in the "old fashioned" style with flowers, and a colourful sateen blouse that she sewed out of cloth from Chiclayo. I also asked many other women in the town about weaving. I took photographs and short video recordings, made notes about different weaving techniques, and tried to distribute my goodwill by purchasing weavings from various women. I found this to be the most acceptable way to drop in on different women and visit with them in the afternoon, when many women are weaving in their back yards. But I talked with doña Beatriz the most, partly because many people told me she was a gifted weaver, and partly 
because she was an older middle-aged woman who seemed to have much cultural knowledge.

Although doña Beatriz wanted me, as a foreign researcher, to document "traditional" forms of weaving that she and other community members believe are declining, she demonstrated caution in disclosing some details of her weaving practice to me. The sensitive topics were primarily related to where she gathers the plants she uses as natural dyes. I observed her to maintain a similar secrecy when I asked her to prepare an herbal remedy for me.

Several months into my fieldwork, I became afflicted with some sort of internal infection. After weeks of tossing and turning at night with strong nausea, burning pain in my lower back, and frequent urination, I approached doña Beatriz and asked her to make me an herbal remedy. Despite my compromised physical state, I ardently wanted to see how the remedy would be prepared. Doña Beatriz evaded my request to accompany her. She did not exactly say no, but she did not say yes either. She told me to return later that day when she had all the plants gathered.

When I returned, she laid a bundle of herbs on the table in her front room. She allowed me to photograph them, but when I asked if she would share their names with me she at first hesitated, and seemed to weigh the consequences of her action before telling me. There was pelo de choclo (the hairs from the top of the corn plant, saved from the previous year as it was not the time of year for corn), yanten, anis (anise), linaza (flax), sintauwa, rumi lanchi, riñon qero, kole caballo, culadrillo (cilantro), grama dulce, amor seco, and chuchuways. There should also be mint, but she could not find any. She also 
adds a potato. All these plants she found in "five minutes" from a nearby hillside, in a particular spot which she evidently did not want to show me.

Doña Beatriz told me she would wash the plants and put them whole into a pot with at least two litres of water to boil for five minutes. Then she would strain the water and store it in an empty plastic soda pop bottle. She instructed me to drink one cup of this liquid three times a day with honey. I gave her about CAD $\$ 4$ for the honey and for her trouble. I asked her if I could watch her boil the plants and she said it would take time as she had to prepare the fire, but it was obvious that she did not want me there observing her.

I was feeling very nauseous and returned home. Later that evening, doña Beatriz brought the herbal remedy in a one-litre bottle to Isabel's house where I was staying. It was light brown in colour, still warm, herbal and woodsy in flavour but not unpleasant. Isabel gave me a cup of the remedy to drink, and sent me up to my room with a bucket to use at night, saying that the remedy would do a "cleansing" (limpia) and that it was bad to go outside at night to use the outhouse as this can do "damage" (daño) and cause further illness. I felt better in the following days, and returned to my normal state of functioning. However, I continued to experience discomfort at night, probably because my body was not accustomed to digesting the large amounts of corn I was served.

I was thankful that doña Beatriz made the herbal remedy for me, and told me what plants she used and how she prepared it. But although we were friendly acquaintances, she did not want to show or tell me where she gathered the medicinal plants. While I believed I had demonstrated to doña Beatriz I was honest and reliable, I did not have the opportunity to show her that I was also discreet. In my understanding, she did not know if 
I could be entrusted with her secret knowledge about medicinal plants. While our relationship progressed over the course of my research, she continued to exercise caution with me - and in particular, about disclosing the location of where she gathered certain plants.

After I had been visiting doña Beatriz for almost a year, she graciously allowed me to film her carrying out the various steps of making a pure wool poncho from start to finish. She was very modest and did not like me watching her all the time. I believe this was a calculated decision on her part, because she knew I would pay a good price for the poncho. Moreover, I had agreed to buy her a digital camera similar my own, which she admired and considered useful. However, doña Beatriz was sure to only share certain aspects of her knowledge with me. One of the very first tasks was dyeing the raw wool. She again evaded my request to accompany her into the hillsides to collect the necessary plants, and instead said I could begin filming the process when she had everything prepared.

When I arrived on the appointed morning, doña Beatriz invited me for the first time into the back of her house, where she had a wide kitchen that overlooked a small, enclosed yard. She had a large pot of bark and leaves boiling over an open fire. These were the leaves of a tree called "andanga" and the bark of another tree called "aliso" to make the red dye for the raw wool. The white wool was already washed and hanging on a clothing line, still dripping with water. It is better to wet the wool before placing it in the pot with the dye, as it will immediately soak up all the water, and the wool will not "take" the colour evenly. 
Doña Beatriz stirred the pot of bubbling water from time to time, and gently blew on the flames to maintain a steady heat. The wood fire gave off a fragrant smell, and the water turned a rich red. After the leaves and bark had boiled for about an hour, she strained the water into a large pail, discarded the bark and leaves, and poured the dyed water back into the pot along with the juice of several limes, a tablespoon of salt, and a small package of powdered commercial dye. This commercial powder could have been a mordant to fix the dye. However, doña Beatriz always called it "dye," and it added an additional redness to the water.

"The dye gives the wool a bright colour, but the plants make the colour last a long time," she said. Both of these qualities of colour - vibrancy and longevity - are valued in the local aesthetics of weaving. Doña Beatriz then added the wet, white fleece, which filled the pot completely and immediately turned red, as if soaking up blood. She stirred the pot with a long stick and brought up the heat of the fire. After the wool had cooked in the dyed water for about a half an hour, she took the pot off the fire, covered it with a lid, and let the wool soak overnight. Then she would hang the dyed wool on the clothesline to dry in the sun. She would later spin the dyed wool into thread for the weaving.

Later doña Beatriz told me that the dye did not work, and she had to colour the wool a second time with commercial dye. "My mother warned me that you should always dye wool alone, because if someone is watching it won't take," she said. "I didn't believe her before." Her comment suggests that using plants to dye wool is secret knowledge that one should not carelessly share with others - just like the bird's whistle in the fable about the waychaw and the fox. 
At first I did not understand why doña Beatriz would not want to bring me with her to collect the plants to make the dye. Other women were willing to take me to their fields for planting, weeding, and harvesting, or to nearby mountainsides to collect firewood, so it was not strictly a problem connected to following her around. In addition, I had talked with various women about medicinal plants. They told me the names and applications of common plants they knew how to use, and some women showed me the plants if they had a small household garden attached to their backyard. So it did not seem that disclosing the names and uses of cultivated plants was secret knowledge.

Doña Beatriz appeared to appreciate my visits, and I had already bought several weavings from her, so I doubted that the issue was that she did not personally "like" me. Nor did it seem probable that she suspected I would return to the hillsides to collect the plants for my own use, although it is possible she feared I would tell someone else where the plants could be found. It is certainly the case that the location of these uncultivated plants is in some way secret. While doña Beatriz told me the names of the various plants she used, she was never specific about where she found them, except to say they grew wild on nearby hillsides.

Yet her comment about having to dye the wool a second time also suggests that if she had taken her mother's warning seriously, she would not have let me observe and film her dyeing the wool at all. I do not mean to suggest that doña Beatriz believed it was my presence itself that changed the efficacy of the dye. Rather, the failure of the dye is an index of something else, for both doña Beatriz and this analysis: The use of uncultivated plants in certain situations is private and secret knowledge, and that knowledge will lose its uniqueness and efficacy if it is shared with others or made public. 
Over the course of my research and visits to doña Beatriz, our relationship moved from one of tentative assistance to conditional trust. When she agreed to make the film of preparing the poncho, she brought me into her kitchen in her family's private space behind the front room. She allowed me to observe her for several hours at a time, answered my questions about what she was doing, and told me many things about how she learned to spin and weave. Her partial trust in me was not a singular event, but developed over the course of many months in multiple contexts. Nevertheless, the manner in which she trusted me did not include full disclosure of her knowledge of plants used for healing and weaving.

\section{Secret knowledge and private information}

Doña Beatriz was unwilling to share more than the most basic information about remedial plants with me. She was a little more forthcoming many months later when she dyed the wool, but even then she did not want to show me where the plants could be found. In another context, both Andrés and his father, don Leonardo, told me that the location of certain remedial plants is sacred knowledge. Those who collect the plants have to follow certain prohibitions, for example, abstaining from eating onion and garlic. They also have to bring offerings of floral waters and ground white corn mixed with water to "refresh" the mountain or cerro.

This is not the case for all and any plants, as common everyday herbs are regularly collected to make teas and simple, one-ingredient household remedies without the proscription of certain actions or obligation to guard knowledge. But the collection and intended use of other plants - such as those used in more complex herbal remedies, 
those that grow wild in the forest and on hillsides, and in particular those used in the sorcerer's ritual table - is knowledge that must be kept secret and sacred. Otherwise, the practitioner may lose his or her "gift" for healing and the plants lose their curative power. In this case, only those people who possess the knowledge and those whom they will pass the knowledge on to (such as their grown children or apprentice) may gather the plants from certain hillsides, or, in the case of particularly sacred plants, enter the "secret garden" of a powerful cerro to collect them.

Doña Beatriz may be a particularly cautious and private person, but she provides an example of the general reticence of community members to share knowledge. This discretion is not limited to contexts of healing or ritual curing. Some knowledge should be kept secret because it would no longer be sacred if it were general knowledge. Other information should be kept secret because making private matters publicly known makes one vulnerable to fellow community members who may unfavourably judge you or envy your success.

It is not possible to keep all such knowledge private in a small and interrelated town. But in my observation, people generally attempt to maintain privacy in these matters for as long as possible. People should ideally not talk about or display them when they are outside of the private spaces of the home and immediate family. Whenever the basic outline of a private matter is made public (such as exceptional success or the circumstances of suffering), the specific details should still be kept hidden from general view.

Knowledge regarding consultations with sorcerers is particularly secret, because if this information becomes known to townspeople in general, that individual may be 
suspected of perpetrating malicious acts of witchcraft him or herself. I did not see or hear of anyone accusing another person of going to a sorcerer to do malicious sorcery. Indeed, such an assertion would violate the implicit cultural norm to avoid and mitigate overt conflict. Nor does it seem likely that the person would fear counter-sorcery, since to the best of my knowledge, sorcery in Kañaris is not used as vengeance or retribution (compare Evans-Pritchard 1976: 5-7). Nevertheless, if it became publically known that a person was consulting a sorcerer, this could generate damaging gossip and unfavourable public opinion about the individual. Even more significantly, it could call the individual's morality into question - not only because sorcery is morally ambiguous, but because sorcery as witchcraft transgresses the unspoken cultural precept not to harm fellow community members. Since one's intentions always remain hidden from others, a person risks being associated with malicious sorcery even if he or she intends to cure (and not cause) illness.

Thus whenever Andrés told me about sorcery, he did so in a hushed tone and in the private spaces of the home, sometimes even closing us behind the door of his storage room to prevent anyone from accidentally overhearing what he was saying. Sorcery is never a topic appropriate for public conversation, particularly between people who do not hold strong mutual trust. Therefore it is not surprising that Mercedes' neighbour would deny that he was consulting a sorcerer when she met him in Pucará, as we saw in the Introduction. Private information must be kept secret because you do not know whom you can really trust - whether another individual will empathize with your position, or use such knowledge for their benefit and to your detriment. 


\section{The uncertain trustworthiness of others}

People in Kañaris stereotype foreigners such as provincianos as categorically threatening. However, people also recognize that fellow community members are threatening and untrustworthy for very specific reasons. This evaluation counters the cultural ideal that fellow community members should always extend goodwill towards one another. Nevertheless, it is based on what people observe others have said and done to harm them or their families.

In my visits to learn about weaving, I befriended another woman in the community. Sometimes a cousin of hers would also be visiting my friend's husband. Although the cousin now lives in another village, he would often return to the town, and I consulted him several times about the traditions of Kañaris. One day, we got to talking about the Upaypiteq Forest. I wanted to gain some first-hand experience of the forests surrounding the town, and I asked my friend's cousin if he would take me to the nearby mountainsides. He enthusiastically replied that he could take me to a relatively untouched forest about a two-hours' hike away. I had never visited the forests before because as a woman, I could not safely walk around outside the town by myself. I also did not know of another person who had the time and interest to show me the forest. The person whom I usually trusted with taking me outside the town, Andrés, was away for an extended period of time. I made arrangements with my friend's cousin to hike to the forest the next time he was in town.

Yet I knew I was taking a risk by going anywhere with a man alone, and so I mentioned my intention to visit the forest to my friend. She did not say anything at first. A couple of days later, she said to me, "You shouldn't go to the mountains with that man, 
he is not trustworthy." And then she told me four stories about why she does not trust this particular man, her cousin.

This man had been married. He had a daughter who was six or seven years old. His wife had recently left him, and gone to live with her parents in another village. More recently she had also taken her daughter to live with her. According to my friend, the man's wife left him because he beat her, and because although she had a daughter with him, the wife's in-laws (the man's mother and sisters) were hostile and unsupportive. The woman could not denounce her husband to the local authorities for beating her because the Justice of the Peace was his friend, and would surely protect him and ignore her denunciation - or worse, accuse her of some scandal or crime that had "provoked" the beating.

The state of the woman's marriage, and the abuse she suffered from her husband, was "private" information, and she would have immediately been placed in a vulnerable position if it were publicly known beyond the ever-present, but unverifiable, sphere of town gossip. So she left her husband, who apparently started an extra-marital relationship with another married woman. My friend told me this man's family is "like that." His younger brother's wife also left him because he beat her; his father beats his wife; and his sisters have had or continue to have extra-marital relationships with married men.

In the second incident, my friend's youngest sister had a friend who was a boy. This boy liked her and wanted to initiate a more intimate relationship, but her sister did not like the boy in that way. My friend overheard the boy talking to the same man we were discussing. The man told the boy that since the girl did not want to have a more intimate relationship with him, he could get a provinciano to attack and rape her, 
potentially leaving her "with child." I assume the idea was that by becoming pregnant, the girl (who was about fifteen years old) would supposedly be compelled to form an intimate relationship with the boy who desired to be closer to her. My friend was horrified by this and advised her sister not to trust her "friend" or that man.

Another of my friend's cousins was indeed accosted by this man when she went to work in her fields alone. He raped her, but she did not tell anyone. As in the case of his wife, this was "private" information that would be more likely expose the woman (the rape victim) to malicious counter-accusations if the incident became publicly known. For example, powerful people such as the local authorities - or regional authorities, for that matter - whom she could report the incident to would likely accuse the woman of having pursued or provoked the sexual encounter herself. However, the woman's silence was insufficient to protect her reputation, person, or material and social conditions of life. Ultimately, the woman acquiesced to an extra-marital affair with the man who had attacked her. The woman's "good" husband found out and denounced her. He left her, although "at least he left her with the house and children."

The most important incident for my friend, however, concerned the death of her younger brother. When her brother was sixteen or seventeen years old, he was suddenly afflicted with an acute pain in his foot. Two days later he died, apparently without medical explanation. The family had called on a sorcerer to cure him, but this had failed. When my friend's father left to call on a second sorcerer, her brother died. Later, a local diviner "saw" that the man who we were discussing was the person behind the sorcery that had caused the boy's death. Thus my friend, her parents, and her remaining siblings do not trust this man. 
Yet this man's mother was my friend's aunt. They are extended family and they will pleasantly exchange greetings in the street. On the surface it looks like there is no problem, a social equanimity that my friend consciously cultivates. But in her "heart of hearts" this man doesn't "sit well" with her or her natal family, first and foremost because they attribute the death of her brother to a deliberate and malicious act of sorcery initiated by this man. She does not trust him, and not just because she does not personally like him or because of things she has heard he has done, but because of what kind of person she has observed him to be and what he has done to directly harm her family. In my friend's eyes, this man has proved himself to be an untrustworthy person.

My friend told me this a few days before I had planned to visit the forest with this man. I did not go to the forest with him, however. Instead I told him that something came up and "another day" we would go to the forest. This was a polite and acceptably euphemistic form of cancellation by local standards, and I knew he would never again mention my request to go to the forest.

This incident stuck in my mind because it was the moment I realized that townspeople do not necessarily trust one another just because they are part of the same interconnected kinship network. Community members are bound to one another through birth and marriage, through relationships of obligation and reciprocity, and through formal and informal exchanges of agricultural work and products. These are the people whom one should be able to trust to follow through on commitments, behave honestly, and act with discretion. Individuals may extend goodwill to others in public view, yet secretly be uncertain if a certain individual is really trustworthy in a particular situation. 
This distrust is not simply because of rumours, but because of things that an individual has done to harm another person or someone close to them.

People in Kañaris recognize that their assessments are more reliable if they are based on what they personally observe. Yet people can also be unsure if a certain individual is trustworthy or not, because they do not usually have complete information about the individual and, particularly, about what the intentions and motivations of the individual may be. This was part of my problem, with my partial cultural competency and limited knowledge of the character of specific people. But the uncertainty of the trustworthiness of others does not just concern visiting anthropologists. It is also something that deeply concerns locals themselves.

In the didactic story of the fox who wanted to whistle, the chakwa helps the waychaw because they are of the same family of birds. They cannot trust the fox, and not just because he is an archetypal "trickster" figure; he is categorically of a different familial lineage. The fox calls the birds "cousin," but the birds say he is of a different family of "four-legged" animals. Yet society is based on the condition of trusting not just members of one's immediate family, but also, at the very least, one's immediate neighbours - who are usually also extended kin in Kañaris. What happens when even people who should be most trustworthy turn out to have malevolent intentions?

From the moment that my friend told me why she does not trust a particular man, the thought began to form in my mind that although various threats to individuals, households, and the community are perceived to come from the outside, the most present and personally experienced threats actually originate from within: Inside the peasant community of San Juan Bautista de Kañaris, inside the community and extended kin 
network, sometimes even inside the very family and household itself. And that is something that makes people feel all the more vulnerable, particularly those - such as women - who are in a structurally weaker position, as we have seen in the case of the victim of rape who could not denounce the perpetrator to the local authorities.

\section{Envy, sorcery, and vulnerability}

When I asked my friend why she believed someone had used sorcery to cause her brother's death, she said someone must have "envied" him or their family. Community members told me that malicious sorcery is always motivated by envy. The possibility of envy accompanies many local social interactions. Envy runs counter to the local moral ideals of humility, equality, and solidarity. These norms are reproduced in what people say and do, without necessarily consciously thinking what and why they are doing them. In this sense, they are part of the Kañarense "habitus." But just as people have the potential for good, they can also do bad. One of the ways this is manifested is through envy.

What is envy in Kañaris? It is the desire to damage or destroy what a rival has, in order to obtain it for oneself. Envy (envidia) refers to something you do not have and excessively want, while jealousy (celos) is about something you have and do not want to lose. In Spanish, as in English, there is some overlap between these two concepts (see Foster 1972: 167-168). Nevertheless, people in Kañaris clearly distinguish between envy and jealousy. "Envy" is a morally transgressive emotion that, if acted upon, is expressed through ill will, harmful gossip, and theft. Malicious sorcery is at the extreme end of this continuum, for it is explicitly intended to damage and destroy what another person has. 
People in Kañaris reserved "jealousy" to refer to the ways in which family members justly or unjustly guard one another. For example, a jealous husband fears that his wife has another lover, and unjustly beats her. On the other hand, jealous parents do not permit their older children (especially girls) to wander freely throughout the town, because they want to protect them from other people's potentially harmful desires.

An envious individual wants something another person has. This can be a material good, such as prosperous fields and animals, or an object such as a blanket or a vehicle. The object of desire could also be a symbolic good, such as health, happiness, political power, or good fortune. The envious individual may publically deny they want the thing they secretly desire, but in private they will scheme to get access to it. For example, a neighbour may "borrow" a tool without returning it, or take things out of another's backyard when the person is away. Theft does occasionally happen in the town, and this is one of the reasons people keep valuables hidden in private rooms and lock their doors. People must exercise extra caution when visitors come to town. For example, some festival visitors had stolen Isabel's blankets, as well as all of her youngest child's clothes that were hanging in the backyard to dry. But people also occasionally suggested that fellow townspeople sometimes steal. For example, Mercedes kept the ducks and turkeys she was raising to sell in the city enclosed in an extra building beside her house, which she told me she locked when she was away so that they would not be stolen. Other people also told me that their chickens and ducks, which run freely inside and outside their yards, sometimes "disappear."

An individual who fears the envy of others guards and protects their desirable goods and attributes. This is not limited to locking valuable possessions away. 
Community members also downplay their symbolically valuable achievements, such as the hard work and personal acumen by which they achieved success in agriculture or business. Partly this is because of the local cultural value of humility, but it is also because successful people do not want to incite the envy of others. Another local cultural value is that everyone should enjoy similar degrees of material prosperity. The personal accumulation of wealth contravenes this unspoken ideal, and so wise people do not publically flaunt their success and prosperity, for example by boasting, wearing expensive clothing bought in the city, or refurbishing their houses. Thus one truck driver in town had painted "DON'T ENVY MY PROGRESS WITHOUT KNOWING MY SACRIFICE" in large letters across the backside of his transport truck. From this perspective, the redistribution of accumulated wealth through sponsoring household and community festivals deflects the possible envy of other people by inviting others to share in a family's success.

The strategies of both the envious and envied person in Kañaris reflect what anthropologist George Foster argued in his polemical article on the topic (1972). Unlike Foster, however, I have found it more helpful to consider envy in Kañaris as a social phenomenon, rather than a psychological one. It is a social process because it affects the relationship between the envied and envious person. Unless one or the other person moves away or dies, they will have to continue to act within the acceptable perimeters of decency as neighours, extended kin, and fellow community members. 


\section{Chapter conclusion}

In daily life, community members interact with one another in a pleasant and respectful manner. People often make a point of acting as if there were no conflict, for example by ignoring a drunken man who is acting inappropriately or disrespectfully, or by expressing an intention to work together. Secretly, however, one individual may still feel envy for another. The person who fears this may suspect that they or their family is the victim of malicious sorcery motivated by envy, as we saw in the case of my friend and her cousin.

The decency and civility of everyday life obscures the distance that people maintain between one another. Such social distance is in part created (and emphasized) by the division between "public" and "private" spaces, as we saw in previous chapter about the house. It is also indicated in how people interact with one another in such a way so as to not reveal "private" information to those outside the household and immediate family, as we saw in the example of doña Beatriz.

One person may only have limited trust in another, even if they have known each other their entire lives and are members of common, interconnected family networks. But since these are categorically the people they "should" trust - particularly vis-à-vis the threatening resident foreigners called provincianos - they cannot act towards one another as if they do not hold mutual trust. At the same time, people cannot know how trustworthy another community member is until one individual has harmed another person or someone close to them. There are potentially serious consequences to mistakenly placing trust in an individual who turns out to be untrustworthy, as the tale about the waychaw and fox warns. 
In spite of the everyday functioning of Kañarense society, in which people extend respect, help, and goodwill towards one another, they also recognize that they are vulnerable to the deliberately harmful actions and envy of others. People often "stereotypically" say it is foreigners such as government agents, transnational corporations, and provincianos who threaten them. In contrast, their vulnerabilities to fellow community members is based on personal experience and observation of particular individuals in specific contexts. But the Kañarense life-world also contains threatening spiritual forces. We examine this in the following chapter by exploring what people in Kañaris do to mitigate their vulnerabilities to non-human entities. 


\section{Chapter 5: Vulnerability}

Holy Week is a time of heightened spiritual and corporeal vulnerability in Kañaris. The climax occurs on Holy Saturday, which locals call the "Gloria."11 On this day, community members bring an effigy of the Devil out of his "jail," a small shack behind the municipal office, and execute him by hanging in the church. The Devil effigy is a wooden figure about the height of a man with a crudely carved face. Andrés told me it is made from higuerón wood, a tree he described as "of the Devil," which can transform one into a devil.

In 2011, several men dressed the Devil in pants, a shirt, sneakers, a yellow mining poncho, and a baseball cap. They also placed a sign around its neck that said "NO TO THE MINE" until one of the ritual authorities tore it off, saying that the Gloria should not be about the mine.

The men carried long whips and a ratchet, a spinning wooden rattle that people use only at this time of year. The group included two "corporals" (cabos), who are supposed to have the maximal authority in the town during Holy Week. In Kañaris, this refers to the Thursday, Friday, and Saturday before Easter Sunday in the liturgical calendar. Several "prosecutors" (fiscales) assist each of the corporals. The corporals and prosecutors are responsible for punishing negligent people who fail to properly observe

\footnotetext{
${ }^{11}$ This is likely in reference to the hymn called the "Gloria" in the Catholic mass. Normally this hymn is sung or recited shortly before the Liturgy of the Word, but it is omitted during Lent and Advent (the weeks leading up to Easter and Christmas, respectively). During Holy Week, the "Gloria" is reintroduced into the mass on Holy Saturday. I am grateful to Leanne Davis for bringing this detail to my attention.
} 
Holy Week. Andrés told me that in the past, they would whip people or force them to carry a large wooden cross around the plaza. But nowadays, Andrés suggested, the corporals do not have "real" power behind their nominal authority. The most important task they perform is taking the Devil to his hanging. The rest of the time, they guard the church and spin the ratchet, which produces a disarming sound.

One of the corporals and his prosecutors paraded the Devil from the far end of the town to the plaza. They stopped at five traditional spots to drink sugar cane alcohol with the Devil. The men have to be drunk because it protects them from evil. In another context, Andrés told me that if someone walks through the mountains at night, they should be drunk, because they will "feel brave" and not be startled by evil apparitions that come out in between midnight and dawn.

In contrast to every other community ritual I observed, no one came out to watch the tipsy procession. Although people stayed inside their homes, they surely knew the Devil would pass through the town that morning, and they could not avoid hearing the ratchet. Andrés told me that if people look at the Devil, "their whole year will be bad." In particular, young unmarried men and women who look at the Devil risk being "won over" by him. That is why I only saw a few unwary children when I went into the street to see what was happening.

The men reached the church shortly before midday. Someone tied a rope around the Devil's neck, threw it over the lintel of the church doors, and raised the effigy in the air. Andrés told me that before the nuns arrived in the 1990s, people hung the Devil inside the church. The nuns disapprove of this unorthodox ritual, and now they only permit the effigy to be hung in the front doorway. 
At this point, community members arrived in the plaza for the hanging. A number of sponsors brought a pig, a sheep, a rooster, and a small wild bird called a "zorzal." The animals are not supposed to bleat before the hanging. People expect them to cry out only after the Devil falls. It is unlucky if they do not, Andrés told me, and their sponsors will have to pay a fine.

The person holding the rope with the Devil firmly tugged it three times and then released it so the effigy fell to the ground. Several community members told me that if it falls with its mouth upwards, "the Devil would win" and "eat" and the community. This is an omen for a bad agricultural year. If it falls with its mouth downwards, the community would win and "eat the Devil," an auspicious sign for a good year. That year, the effigy fell face upwards. Afterwards, people quietly commented that it would be a bad year.

After the Devil was executed, the authority of the corporals that had begun on Holy Thursday ended. According to Andrés, a decade or two ago the corporals reported their work to the mayor. They told the mayor who had complied with the obligations of Holy Week and who had not — those whom they had punished. For example, the corporals inspected each house to see if people had cleaned them and placed a cross with flowers over their front doors. They also watched people to see if they kneeled and crossed themselves before entering the church. Those men who did not comply with Holy Week were obligated to become corporals and prosecutors the following year. This reflects the "upside-down" state of affairs in the world during this time. It is morally questionable people who have authority while the Devil wanders free, rather than morally commendable people, as it should be. 
Before, people who stayed home and did not attend the hanging were accused of being thieves. Yet relatively few people come now, and Andrés suggested this is because the old social sanctions have broken down, partly because the present mayor is not willing to temporarily sign over his authority to them.

Another thing has changed from the Holy Weeks that Andrés remembers from his youth. Before, this was a time when people from surrounding villages and hamlets came to the town for communal work and exchange. The corporals oversaw the cleaning of the roads in and around the town. Younger men used hoes and spades to clear and level the pathways, and older men cut back encroaching branches with machetes. Women exchanged foods that they had produced in different agricultural zones. For example, potatoes from the high-altitude shaqlla, corn from the middle qeshwa, and cherimoya and sugar cane from low-lying yunqa. There was also a ritual battle between people from these different areas of production and residence. Ethnographers have documented similar ritual battles in the Andes of southern Peru and Bolivia (see Bastien 1978: 57-58; Gelles 2000: 99; Gose 1994: 168). The standard explanation is that the structured violence - and the blood produced from flying stones and physical altercations - serves to fertilize and revitalize the earth for another agricultural year. However, the communal work, exchange of products, and ritual battle no longer take place in Kañaris today.

Community members told me that Holy Week is a dangerous time of year because "God is dead" and "the Devil is wandering free." They have to follow certain prohibitions in order to manage the risk of evil during this time. For example, no one is supposed to punish children, hit dogs, or bathe — that is, have bodily contact with cold water, which can bring illness. According to Andrés, one should not walk alone because 
all the "devils" or "evil spirits" are wandering around, especially in the hillsides surrounding the town (see also Harris 2000: 39). For example, he said, you may see strange animals, large snakes, or pots of gold on the road. But when you reach the spot where these things appeared, they do not exist. They are manifestations of the Devil, and you become sick after seeing them.

In addition, no one is supposed to work in their fields, because the earth is "the body of God." For example, Andrés said, peas are his eyes and corn is his hair. Andrés' brother-in-law similarly told me that because Christ is dead, working the earth would be like adding injury to his wounds. During this time, Christ is closely associated with the earth and the proper state of the world (for a similar case in southern Peru, see Gose 1994: 165-169). In the absence of Christ, God's representative on earth, the Devil is free to move and act. This poses a threat not only to the productivity of the land; it poses a threat to the health and well-being of individual persons.

From the local perspective, "Holy Week" ends on Saturday with the hanging of the Devil and return of God. The day before, Good Friday, there is an enactment of the Passion of Christ, which we saw in Chapter 2. Later that day, people dress statues of saints housed in the church and carry them on litters to visit each house in town. The litter-bearers play music and sing hymns, and the householders provide the saints with offerings such as corn and eggs to increase their prosperity and productivity in the upcoming agricultural season. In the evening, there is a mass and a procession with the statues of the Virgin Mary (Our Lady of Sorrows) and Mary Magdalene. Holy Friday ends with a late-night vigil for the "fallen" or dead Christ. The corporals cover a statue of Christ with a white shroud and lay him a glass casket in the church. People come to light 
candles and pray over the body, and the corporals and prosecutors sing mournful funerary songs, just as if it were a real funeral.

People say that Christ "rises" from the dead when the Devil falls from the church rafters the next day, Holy Saturday. With the Devil killed and Christ resurrected, the "ritual of reversal" (Turner 1969: 166ff) that began on Holy Thursday is completed. God returns to the land, people no longer have a heightened fear of encountering evil spirits, and the world is put right again. The nuns insist that Easter is on Sunday, when the "real" resurrection of Christ takes place according to Catholic teaching. They give a mass on Sunday to celebrate this, but in local understanding and practice, it is not as important as the hanging of the Devil.

\section{Vulnerability, malicious spirits, and illness}

Holy Week is one of the few times of year that people in Kañaris name the Devil as an individualized, Christianized entity that is diametrically opposed to all that is good, represented by God and Christ. The Devil poses a threat to the entire community. If this threat were not controlled in some way, the land would not be productive and people would be continuously afflicted with illness and misfortune. The annual ritual of hanging the Devil is in part about the community managing the threat posed by this manifestation of evil. During Holy Week, good and evil cannot exist in the same place at the same time: When Christ is dead, the Devil roams free. When the Devil is killed, Christ returns.

People in Kañaris perceive themselves to be vulnerable to naturalistic, social, and spiritual forces. "Naturalistic" forces include the unpredictability of the weather, which locals depend upon for their crops and animals to support their families, as we saw in the 
chapter on the household. Luck is another naturalistic force, since it is unpredictable and uncontrollable, yet in local thought affects how people experience success and suffering. Ill-being can also result from "social" factors, that is, in the particular relations between neighbours and extended family. In the previous chapter, we saw that community members perceive themselves to be vulnerable to harmful gossip, ill-will, and malicious sorcery perpetrated by fellow community members. One of the ways individuals manage this vulnerability is by keeping some activities private and certain forms of knowledge secret. Finally, the hanging of the Devil points to the "spiritual" forces that threaten community members. The Devil is one of several non-human entities that attack people and cause illness. People can also mitigate their vulnerability to malevolent spirits through practices of avoidance and rituals of protection.

The non-human entities that threaten people in Kañaris include the singular Devil, the wandering souls of the condemned dead, and numerous "devils" (diablos) and "evil spirits" (malos espiritus). Apart from the Christianized Devil, these immaterial beings do not have individual names. Evil spirits only bring harm, unlike the place-based spirits called encantos, who have the potential to also help people. The stories people told me indicate they experience encounters with malevolent spirits as a physical attack or intrusion. For example, a person can be knocked to the ground by an unseen entity, or suddenly frightened so that an immaterial part of their person - their soul - becomes detached from their body.

The evil spirit invades upon the person, producing disturbing effects that result in his or her inability to function normally. For example, the victim has trouble sleeping or eating, suffers from debilitating bodily pain, or is overcome by anxiety or listlessness. 
These symptoms prevent the individual from carrying out their normal roles and responsibilities. My interlocutors always framed their embodied experiences of vulnerability to non-human entities in terms of "illness" that disrupted their normal state of being. When a person encounters an evil spirit, he or she becomes sick, and must seek an appropriate method of healing in order to return to the tasks and responsibilities of their daily lives.

An encounter with an evil spirit is not simply a matter of "bad luck." Misfortune is when something unexpected and uncontrollable prevents a person from achieving his or her present goal. For example, bad luck is when the rains wash out the roads so travellers are unable to reach the highway, or when a person's cow dies falling down a hill, thereby terminating the owner's hope of a future return on her investment. Encountering an evil spirit is unfortunate, but it also presupposes the intention and subjective agency of something apart from the person. The external will for the given misfortune to befall a particular person originates in the evil spirit or devil. The nonhuman entity causes illness in a victim because of its self-generated intention to harm them. In other words, this class of illness has been caused by an agential entity that wants to harm a particular person. This is what medical anthropologists call a "personalistic" causal factor of illness (see Foster 1976).

Such illness does not arise from what the person has done or failed to do. It is simply the nature of evil spirits and devils to harm people. Therefore, people avoid leaving their houses during the times they will most likely encounter an evil spirit. This includes Holy Week and after dark, especially in the "undomesticated" spaces on country roads beyond the town. In addition, evil spirits are often associated with particular places, 
and so people also avoid certain bodies of water, gullies, and hillsides they know to be the abode of a malicious spiritual entity.

In this chapter, we explore how people in Kañaris perceive and respond to their corporeal vulnerability to devils and evil spirits. This complements the social vulnerabilities outlined in the previous chapter. Locals have distinct strategies to mitigate and manage their vulnerabilities to "social" factors and "spiritual" forces. This range of vulnerability is implicit in local notions of illness, healing, and sorcery. Since the Kañarense practice of sorcery encompasses both witchcraft and ritual healing, we need to have an ethnographically grounded understanding of how sorcery, vulnerability, and illness overlap. We also need to outline the distinct responses and curative practices people employ to overcome their susceptibility to attack or harm from different forces at work in their lives. Once we have done this, we will be ready to understand how vulnerability to both human and non-human agents intersect in sorcery.

\section{The Devil, the body, and the house}

The hanging of the Devil during Holy Week is the most important community ritual by which Kañarenses manage their collective vulnerability to malicious spiritual forces. During this time, the threat of the Devil is temporarily foregrounded in what people say and do. The management of the threat posed by the Devil is the community's most important spiritual task during Holy Week — rather than, for example, the resurrection of Christ (as Catholic doctrine would have it), or the renewal of the earth and social relations for the next agricultural year (as Andrés suggests was the case in the past). 
People are also vulnerable to the unseen presence of the Devil at other times in their lives. This is indexed by three traditional life-cycle rituals: child baptism, house baptism, and a child's first haircutting. My interlocutors indicated that these household rituals are necessary so that individuals are not "overcome" or "won over" by the Devil.

All three ceremonies are expensive for the family to host. For example, they each include a full Kañarense feast. This is the reason many people gave me for not performing one or another event. In addition, people say, since the nuns arrived, they have reproached community members for performing their own baptisms, which conflicts with Catholic doctrine. From a synchronic, slice-in-time analytical perspective, it appears that the persuasive force of these rituals has declined for community members in recent years. As anthropologist Stanley J. Tambiah has argued, rituals need to be periodically refreshed in terms of a community's changing present concerns in order to remain relevant for practitioners (1985: 165-166). Although Kañarenses still undertake these ceremonies, they are not as common as people say they were a generation ago.

The traditional Kañarense baptism is called the "saving water" (agua socorro). It happens about two weeks after an infant is born. ${ }^{12}$ This is a household blessing and naming ceremony for the newborn. It is totally separate from an ecclesiastical, Catholic, baptism that the child may or may not have at a later time.

When the infant is born, the parents decide what name to give him or her - for example, the name of a grandparent. Then they ask a married couple to be the child's godparents and their co-parents, and they invite family members and friends to come to their home on the appointed night. According to Andrés, the ceremony takes place in the

\footnotetext{
${ }^{12}$ At the time of birth, the infant also receives a blessing called the "alsa" from the midwife. I do not have further information about this ritual event, however.
} 
corner of the front room that faces the rising sun. If it is done where the sun sets, people say the child will die. The godfather stands on the right-hand side of the infant and the godmother on the left-hand side. The godfather "baptizes" the infant with the chosen name by blessing him or her with "holy" water — water mixed with ground white corn — and reciting two Catholic prayers, Our Father and Hail Mary. The "saving water" baptism concludes with a feast of roasted lamb, drinking, and dancing, as in all community and household festivals.

Andrés told me the traditional baptism is called the "agua socorro" because if a child does not have it, the Devil will conquer or "win" him or her over. This is indicated if the infant often becomes sick and frightened. When this ceremony is performed, the family has "beaten" or "conquered" the Devil. Thus the baptism blesses and protects the child, at the same time as the parents recognize his or her personhood, and establish a permanent relationship with their co-parents. Andrés baptized all of his girls in this manner. I knew several children in Kañaris born in between 1990 and 2004 whose parents performed this baptism for them, but I did not hear of this ritual being performed for a newborn child during the time I spent in the community.

The infant baptism is mirrored by a second household ritual. People call it the "house water" (wasi yakun in Quechua) or "saving water of the house" (agua socorro de la casa in Spanish). While the traditional "saving water" baptism is intended to protect a newborn person from the Devil, the house baptism protects the entire household. A married couple performs this ceremony for their newly constructed home, which they typically build a couple of years after marriage, once one or two children are born. 
The house baptism bestows a name for the house and co-parents for the married couple. It also blesses and protects the house and household members from the Devil. As Andrés described it for me, the ceremony again takes place in the corner of the front room that faces the rising sun, and the godparents recite Catholic prayers. The couple hangs colourful cloth ribbons on the lintels above each doorway. The main part of the house is baptized in the name of a male saint, and the detached kitchen is baptized in the name of a female saint. For example, Andrés and Isabel named the main part of their house after San Juan and their kitchen after the Virgen de la Merced. "Holy" water of ground white corn is sprinkled on each corner of the main room and the kitchen, as well as the top of the roof. The house baptism again concludes with a feast, drinking, and dancing.

The house should be baptized as soon as the couple constructs the main walls and the roof. Andrés and Isabel performed this ceremony for their home in the mid-1990s. However, several young couples I asked told me they had not undertaken a house baptism, saying that it costs too much money. Nor did I hear of any house blessing ceremonies during the building season in August - November 2011.

The third protective ritual I know of is for children between the ages of two and five. This is the first haircutting ceremony, which people call the "haircutting" (corta pelo in Spanish), or "knot or mat of uncombed hair" (landa in Quechua). Since the child has been born, the parents have left his or her hair uncut. In previous times, they also did not comb the child's hair. When the child's hair has grown long enough, the parents name godparents and host a feast to cut his or her hair. 
Andrés' sisters told me that if a child does not have their landa hair cut, he or she is disobedient, cries often, and throws tantrums. The ends of the hair hold the child's misbehaving temper, and when the hair is "refreshed" with holy water and the "matted" hair cut, this removes and "conquers" the Devil.

In October 2011, I attended a haircutting ceremony for the young son of a couple who lived next door to Andrés and Isabel. The godmother "refreshed" the child's untamed, landa hair by sprinkling it with "holy," ground white corn water. One at a time, she called upon each of the guests to make a small monetary donation to the child and cut a lock of his hair. Each of the guests then had to drink at least one serving of sugar cane alcohol (yonque), and one cup of sugar cane juice (guarapo). The haircutting took several hours, followed by a full feast with a night of drinking and dancing.

After the ceremony, Andrés told me the parents take the saved hair clippings to the forest in the nearby mountains. They deposit the hair in the crook of any tree where a large bromeliad called "tuyo" grows. People say this plant is thereafter the "soul" or "shadow" of the child. According to James George Frazer's classical anthropological theory of magic, the logical implication of this practice is that the child is protected by separating a part of their person from their body and storing it in a secret place, so that whatever misfortune befalls the embodied person, a part of them remains safe (see Frazer 1960: 45-47, 773-774, 787). My interlocutors did not elaborate upon their understanding of the connection between the "tuyo" and the child. But based on my experience of Kañaris, it is reasonable to assume that the child's haircuttings are stored in the bromeliad in order to protect the child from the omnipresent threat of malevolent spiritual forces. 


\section{Evil spirits}

One day, Andrés and Isabel took me to visit a local herbalist (remediera), doña Milagrosa. She lived just outside of town, on a hillside behind the cemetery. Other people were afraid of living so close to the graves of the dead, but not doña Milagrosa. I brought her some bread, and she gave me three eggs from her fat chickens. I had met her the previous August, and she was glad I came to visit her again to ask her about herbal remedies and "cleansing with guinea pig" (limpia con cuy). Everyone in town knows that she is the most capable and gifted person to heal by this traditional method.

I told doña Milagrosa that I had not been feeling well for several weeks, with trouble sleeping and stomach upset at night. She brought a small guinea pig out of her house and rubbed it over my body in a downwards-sweeping motion. The guinea pig squealed, but doña Milagrosa held it firmly in her hand and vigorously rubbed it over my head, torso, back, arms, and legs as I stood outside her house. She talked casually with Andrés and Isabel as she did this. After about ten minutes, the animal died, and doña Milagrosa brought it to the edge of her yard to examine it. She used her fingernail to slit open the soft underside of the guinea pig, and deftly turned the hide it inside out. Isabel poured water over the animal's body, and doña Milagrosa inspected the inner organs. She told Isabel what she was seeing in Quechua, and Isabel provided a brief synopsis for me in Spanish. Doña Milagrosa saw some discolouring and swelling in the animal's intestines, and said that I would need a further "cleansing" with another guinea pig. I knew that the remediera normally prepares a complex herbal remedy based on her diagnosis. But she did not volunteer this, and I did not arrange a second rubbing. I had 
already seen what I wanted to see, and doña Milagrosa seemed to understand I only wanted to learn about "cleansing with guinea pig," not really cure a persistent illness.

When she finished, doña Milagrosa threw the animal's corpse into the branches of the trees of her lower field, saying that no chickens or other animals should eat it, because it would make them sick. She and Isabel told me that the guinea pig acts "like an x-ray," so that the inner state of the client is reflected in the inner state of the animal. Through the physical contact of the two bodies, the guinea pig also extracts some of the illness from the person's body. This is why people say they "feel better" when they have a limpia con cuy, and why people and animals who come into contact with the animal's corpse will become "contaminated" with the same illness that afflicts the client.

The guinea pig is an object that physically mediates the relation between the person and the source of their illness. In this sense, limpia con cuy resembles the curative methods of sorcerers, who also use mediating objects to extract illness from the client's body. But unlike sorcery, limpia con cuy is not a sacred practice set apart from everyday life and characterized by the esoteric knowledge of ritual specialists. The remediera has a particular "gift" in being able to use the guinea pig to extract illness and make a proper diagnosis, but in principle anyone can learn about herbal remedies. More importantly, remedieras do not treat potentially life-threatening illnesses attributed to powerful encantos, as these conditions can only be treated by sorcerers. In addition, remedieras only have the ability to cure, and cannot also cause illness. As one community member told me, remedieras are "clean" because they cannot do malicious witchcraft to harm people, like sorcerers. 
Remedieras primarily treat illnesses attributed to cold wind, hot sun, morning dew, or tainted food. These are all "naturalistic" causative agents in George Foster's sense (1976): the illness is a result of the inherent quality of the thing, and not a personal motivation. As they are persistent conditions commonly experienced by community members, remedieras are important local healers. I talked with several prominent remedieras in and around the town, and they all described a range of common conditions that they treat with herbal remedies. Although the women named similar illnesses, their herbal remedies were all different, and consisted of five to twenty distinct herbs and plant parts. One elderly remediera told me she learned about herbal remedies in a time of "plague," when many people were dying. Thus it seems that before the arrival of the government-funded medical post in the 1980 s, remedieras were the primary health care providers for community members. To the best of my knowledge, they are always women, who are either self-taught or have herbal knowledge passed to them by a mother or other female relative.

In addition to common illnesses caused by "naturalistic" agents, remedieras can treat illnesses attributed to the minor evil spirits called malos espiritus and diablos. These "personalistic" causative agents intend to harm a specific individual who happens to pass by the pond, stream, gully, outcrop, or hillside where they reside. Doña Milagrosa walked over to the edge of her yard, which overlooks the town's lower fields, and pointed out and named the nearby places that have malos espiritus. One evil spirit is in the shallow stream that crosses the road leading to the Kañariyaku River, and another lives in a hillside along this same road. An evil spirit also lives in the pond called Qoĉa on the hilltop to the east of the town. Several people told me this pond grabbed sheep, cattle, and 
even men who got too close, sucking them in an underground tunnel to the coast. Andrés knew these same places, and also told me of a boulder that used to be near his parent's house. He described this boulder as the "particular enemy" of one of his sisters, with a malo espíritu that made her sick many times when she was young. The boulder was removed when the municipal council made way for a concrete arena and meeting hall, the "coliseum," and no evil spirit remains in the place it once stood.

Andrés joined doña Milagrosa in pointing out all the places with malos espíritus around the town. They commented that when they were younger, children were often frightened by these places. Nowadays, it seems people do not approach these places with as much trepidation as they once did, although young children are still attacked by malicious spirits.

For example, a child can be startled when he or she passes by a place with a malo espiritu, suddenly crying out or falling down. The evil spirit living in the stream or rock is hungry, and has "grabbed" the child's soul as their food. A child with this illness of "soul fright" (susto) is unsettled, especially at night. They may cry, talk, or walk in their sleep, or have stomach pain, fever, and diarrhea. Andrés told me that susto affects children more often than adults because their souls are soft and pliable, "green like a plant." Therefore, their souls can be easily frightened out of their bodies and grabbed by an evil spirit.

Knowledgeable parents can cure the child themselves, or bring them to a remediera such as doña Milagrosa. The healing methods are all variations of rubbing something over the child's body and calling their soul back. For example, Mercedes's mother told me that she takes kernels of five different types of corn in her hand and rubs 
them over the person's body. Then she traces a cross in the ground where the child was frightened, taps it with a large knife, and says, "get up little soul, this is your owner." Andrés' mother takes five guinea pig droppings with a piece of charcoal and some salt in her right hand, and the kernels of two different types of corn in her left. She rubs these over the person's body, saying "little soul, here is your food, let the soul return."

Doña Milagrosa cures susto with white corn and salt. She rubs these over the patient's body, and plants the corn where the child was frightened. If the corn grows, the child's soul has returned to their body, and so they will get better. If the plant does not grow, the evil spirit still has the child's soul. She also said susto can be treated with the hide of an anteater or fox. She rubs the hide over the person's body, and this "draws out" the illness and cleanses the child. Then she slaps the hide on the ground where the child was startled, saying, "let's go, little soul," to call the child's soul back to their body. If the malo espíritu is strong, it will not release the person's soul. If the client is not brought to a more powerful healer, they can die.

People most commonly identify malos espíritus are as residing in particular places in the local landscape. Andrés told me they also live in ancient burial mounds (huacas), which he described as the remains of immoral pagans (gentiles) destroyed by God. "Now they suffer for their food," he said. The corn that a parent or healer rubs over the patient's body to call their soul back is the food to feed these hungry spirits. Anyone with a "capable hand" can cure susto in a child. But if an adult has soul fright, it has been caused by a stronger entity, such as a mountain spirit. This must be treated by a "stronger and wider-ranging" cure, presided over by a sorcerer during an all-night healing ritual. 


\section{Souls of the dead}

In the above examples, my interlocutors used the Quechua word "pichqa" for the phrase I have translated as "little soul." Pichqa means "five," and also refers to the fifth day after a person's death, when the deceased's family washes their clothes. The word is associated not simply with the five days of a wake, but also with one of the person's two souls, called the "shadow" (sombra). When the person is living, the sombra is an integral part of their health and vitality. If an evil spirit separates a person's "shadow" from their body, he or she falls ill. If their sombra is not returned, they will weaken and eventually die. After a person's death, their sombra hangs around the things they wore, the tools they used, and the places they lived. In order to send the deceased's sombra on to the afterlife, the family washes their clothes, buries their body, and properly prays for them upon their death, the six-month anniversary of their death, and All Soul's Day each November.

The second "soul" or "spirit" (alma, espíritu) cannot become temporarily separated from a living person's body, for its loss is coterminous with death (see Polia 1996: 161). Andrés suggested that when a person dies, their espiritu immediately leaves this world and goes on to the next. At least, that is the case in normal circumstances. The espiritus of sinful people are condemned to stay in this world, wandering around at night and attacking the living who encounter them, particularly just after sunset and before sunrise.

Andrés told me of a particular kind of ghost-like apparition called the "kaw." This is the soul of a dead person who committed incest in life - for example, by having sexual relations with a sibling, parent, or co-parent. It could also be the espiritu of 
someone who did not have relatives to pray for them after their death, such as orphans. Therefore, his father taught him to pray for the unknown and forgotten dead on All Soul's Day. These spirits make wailing sounds like a passing airplane or crying child: Woooo. If you encounter such frightening and sickening spirits, Andrés told me, you should recite seven "Our Fathers," seven "Hail Marys," the Catholic Creed, and say something like, "get away from my body."

Sometimes the soul of a dead person visits a relative. But unlike Mercedes' positive experiences with the intercession of her deceased father, these ghostly encounters cause illness. Andrés said this type of illness can be cured by going to a person who heals with prayer (rezador). For example, after a person dreams of a dead relative who appears "just as they did in life," they become sick. The healer takes the kernels of five types of corn in one hand, and pieces of the deceased's favourite foods in the other, rubbing them over the victim's body while praying. The client then has to follow certain prohibitions, such as not sleeping alone and not eating certain foods.

The wandering espiritus stuck in this world are among the disembodied evil spirits that come out at night. The night is a dangerous time to go outside one's house. This is why one should have a drunken person leading them when walking after dark, since the drunk will feel "brave" and not be easily frightened. A person can also become ill from "evil night" (mala noche), or the "wind of the dead" (aire de los muertos). People also call this "[the] mark" (marca), or "evilness" (malora). It is another type of "soul loss" caused by hungry spirits, and causes pain in the head or stomach. These conditions can be identified by visiting a diviner, someone who reads cards or the bubbles in a glass of sugar cane alcohol. Mercedes's mother told me that the "wind of the dead" should be 
treated by rubbing corn over the victim's body while reciting Our Father. But instead of burying the corn kernels, as with susto, you leave them in the brush on the hillside that the victim passed, with a sprinkling of "holy water," water mixed with ground white corn.

Andrés told me he did not really believe in these spirits until he had encountered them himself. One time, he had gone to a distant hamlet for a meeting. He stayed to play a soccer game, and when it was time to leave, it was already dark. There had been a heated argument during the game, so he did not want to spend the night there. A friend of his said he could stay at his house in another hamlet, and so they began walking. A few weeks earlier, his friend's mother had died. Andrés had been one of the pallbearers carrying the casket to the cemetery. When the burial was to take place, the deceased was already decomposing, and a foul smell came from the casket. When Andrés and his friend passed by a certain tree where the pallbearers had stopped to rest, they smelled the same smell. This disturbed Andrés, but they walked on. Then he had the sudden fear that he would sleep in the same spot the body of his friend's mother had laid for the wake. At the moment when this thought entered his mind, Andrés could not walk any further. He felt a great heaviness in his body, as if something had grabbed his belt and was pulling him from behind. Andrés could do nothing but repeat the opening lines of "Our Father."

Another time, Andrés was walking alone at night. He saw a tall, bent man with a poncho and a bag. The man's poncho went down to his feet, and Andrés could not see his face. Even though the man was hunched over, he walked very fast. Andrés was suddenly compelled to follow the man. But the faster Andrés walked, the faster the man went, 
seemingly gliding over the surface of the earth. Andrés finally pulled himself away when the man entered a cemetery.

In Andrés' next experience, he was again walking on a mountain road alone at night. Suddenly something violently knocked him over. Yet no one was around him — it was "as if in a dream." He tried to get up, but he was knocked down again, to fall down a hillside. Then, a couple of weeks later, he was walking homewards from the highway where his bus had dropped him off. As he passed a certain mountain, he heard a wail from the hillside. It sounded like a child crying. Now the sound was around his feet, and he was unable to take a step further. He sat down and smoked a cigarette - which everyone in the Andes knows helps in the mountains, not because it "calms the nerves," but because the strong smell and smoke drives away evil spirits. He knew the crying was coming from a "kaw," the haunting soul of a person who had committed incest, and who eats the intestines of guinea pigs and chickens.

Another evil spirit is called the "Aĉkay," who appears as an old woman and attacks pregnant women, eating their unborn children. A lady in town told me of a similar haunting. She said a "monster" was going from one hamlet to the next attacking women and children. It could reach inside their bodies and eat their intestines. So people were leaving it food like corn and potatoes to eat instead, which were always gone in the morning. The monster looked like a person, but half of its face was burnt so you could see the muscles and bones. It came on the wind, and would appear and disappear suddenly in the night, coming even through doors that were shut tight.

Perhaps this lady was pulling my leg. When I told Andrés about this, he wryly commented that it was superstition. Nevertheless, when he told me of his own 
experiences, he could not find any rational explanation for his bodily reactions: an inability to walk, being knocked to the ground, and hearing, smelling, and seeing strange things. He concluded that they must have been encounters with evil spirits. "It is powerful when you see these things for yourself," he said.

Thus it seems the perception of vulnerability to evil spirits is closely related to its corporeal experience for people in Kañaris. For example, when Andrés and doña Milagrosa commented that children do not feel as threatened by malos espiritus today as they did in the past, they did not suggest this was because these evil spirits do not exist. Rather, they suggested that it was because children do not perceive the threat until they have experienced it themselves. While the people of Andrés' generation and older I talked with had personal experiences of encountering malicious spirits, children in town do not seem to be worried about walking by certain places. For example, I saw three girls wading in the stream that doña Milagrosa pointed out as a place with a malo espiritu. And while Andrés' eldest daughter knew the stories of the Qoĉa, she did not seem to think the place was really dangerous, and she told me brazen boys sometimes go swimming there.

Perhaps this is because adults are also talking about malos espiritus less often. Andrés told me that before, people used to protect themselves from evil spirits and the souls of the dead by carrying certain objects and modifying their persons in specific ways. For example, they would place garlic or the strong-smelling herb called "ruda" in their pockets. Women wove flowers into their belts, and men would drink the blood of a black bull, which made their shadow-souls look like a bull. People still avoid going out at night, but no one told me they carried repellent objects or consumed particular substances 
for protection. Although Andrés suggested that people do not perceive the presence of threatening malos espiritus as they did in his youth, his personal stories also indicate that when he was attacked by unseen forces on country roads at night, he could find no other explanation.

Perhaps the discursive and experiential fields of vulnerability are shifting away from the animated landscape. However, in the absence of long-term, diachronic research over many years in the same place, it is just as likely that younger generations of Kañarenses will "perceive" and "believe" in evil spirits only they have had an inexplicable experience themselves. From what I have observed, people in Kañaris still find themselves to be vulnerable to illness, misfortune, and suffering brought on by these spiritual forces and non-human entities.

\section{The local notion of evil}

The Devil, malos espiritus, and the harmful souls of the dead matter to people because they cause illness and suffering. Community members are vulnerable to these "spiritual" forces of evil, as well as the "social" evils discussed in the previous chapter. The existence of evil matters to people in Kañaris. This is not a category of analysis that I am bringing into this discussion. It is something that is articulated by what people say and do.

The Spanish word mal refers to something that is either "evil" or "bad." In Kañaris, people use $\mathrm{mal}$ in three distinct yet interconnected ways: as a qualitative evaluation of circumstance, a moral evaluation of intentional action, and a thing that exists in the world. For example, one can say, "I feel bad [ill]": Tengo mal. One can also 
experience "bad luck": mala suerte. Alternatively, one can say that so-and-so "is a bad person": Es malo. People also use this word to identify "evil spirits": malos espiritus. Community members explicitly connect illness and something that is evil when they talk about the actions of the sorcerer in a ritual healing session. They say the sorcerer "extracts" the illness and evil from the client's body: Saca [el] $\mathrm{mal}$. This invisible, sickening substance is also called "damage" (daño). An evil person or thing causes damage to another individual. People can experience, observe, do, and be adversely affected by "mal."

As an individual's qualitative evaluation of their circumstance, $\mathrm{mal}$ is associated with illness and misfortune. In local understanding, this suffering occurs independent of both a person's intentional actions and their moral worth. Community members observe that bad things happen to good people, just as morally questionable people can be healthy and prosperous. For example, unfavourable weather conditions, unexpected delays in travel, accidents, and sudden illness can all be described as "bad luck" (mala suerte). Although people sometimes say malicious witchcraft is the reason an individual experiences these adverse circumstances, witchcraft is not always at work when a person has "bad luck." In this sense, to experience bad luck is to experience mal.

Luck is another local category that has many layers of meaning. For our present purposes, the important thing to know is that "luck" is a concept people use to account for the unpredictable and uncontrollable distribution of suffering. In Kañaris, luck is not something that a divine being allocates or withholds because of what an individual has done or failed to do. It is something that exists in the world in limited quantities, and which can help or hinder people achieve their goals. Although people are responsible for 
what they do, they are not responsible for their state of luck. At any given moment one person can have it and experience "good luck," while another lacks it and experiences "bad luck." In this sense, mal is the existential evil of human suffering. It cannot be predicted, controlled, or accounted for in a completely satisfactory way (for this problem in contemporary Western thought, see Neiman 2002: 238, 281). For people in Kañaris, it can only be managed and responded to, for example through curative rituals to cleanse oneself of "bad luck."

In the second sense, $\mathrm{mal}$ is a moral evaluation of an individual's intentional action. This evil is not arbitrary or unexplainable. It is the outcome of the deliberate and conscious actions of particular people, and therefore responsibility can be assigned for the suffering that it produces. Evil actions contravene fundamental values in the community, such as respect, generosity, and solidarity. Actions that disregard these community values benefit the individual at the expense of others. Such actions may be pre-meditated (for example, stealing) or spurious (such as violently hitting another person). Nevertheless, the perpetrator can be held responsible for his or her actions, and the injury or harm they cause another person. The paradigmatically evil action is a person consulting a sorcerer to do malicious witchcraft and harm an adversary or rival whom they envy. This type of evil is enacted by a deliberate decision, and therefore to identify witchcraft as evil is to make a moral evaluation of the people involved.

Malevolent spirits and devils that cause passers-by to become sick are also morally evaluated as evil, acting on their individualized intention to harm a specific person. This evaluation is explicitly marked in their general name, malos espiritus. It is the inherent nature of these types of spirits to harm people. For example, unlike the 
encantos, evil spirits never help lay people. Some sorcerers address particular malevolent spirits through the power-objects on their ritual tables, such as the stones of the preChristian spirits called gentiles. From the perspective of non-specialists, however, these and other evil spirits only bring illness and misfortune. In Foster's (1976) terms, they are "personalistic" causative agents of illness, with a self-generated motivation to harm an individual. In this sense, malos espiritus and similar non-human entities can also be held morally responsible for the suffering they cause people.

Finally, people in Kañaris also talk about $\mathrm{mal}$ as a thing that exists in the world that is, in the Platonic sense of an object of perception that exists independent of its experiential manifestations. No one explicitly told me what this evil is or where it comes from. Based on what I have observed, heard, and read about sorcery, mal is an invisible substance that originates in the encantos and enters a person's body, where it festers and causes illness, misfortune, and suffering. Through the ritual healing session, the sorcerer uses sacred objects and actions to "extract" this sickening substance from the client and send it back to its source.

We will examine this process in greater detail in the following chapters. For now, it is sufficient to know that the encantos do not intend their power to harm an individual. Rather, their power becomes evil and sickening when a sorcerer directs it towards a person with the intention to cause them damage and harm. This illness-inducing substance can also "contaminate" people who accidently come into contact with ritual objects previously used to cure a client. This is why, for example, doña Milagrosa had to dispose of the spent guinea pig in such a way that people and farm animals would not touch it and become sick themselves. The ritual actions of both remedieras and sorcerers 
suggest that in this sense, $m a l$ is a thing that causes people to suffer because of the physical contact between an individual and the mediating object that contains the invisible substance.

These three senses of "evil" in Kañaris are not mutually exclusive. More than one understanding of $\mathrm{mal}$ can coexist in specific situations. For example, in illness attributed to malicious witchcraft, evil or mal is indexed through both the intentional action of the perpetrator and the invisible substance that contaminates the victim. In other instances, mal can be present without a moral evaluation. For example, a person can "feel bad" because they "have" bad luck. In each case, however, evil or mal is closely associated with a particular person's suffering.

\section{Chapter conclusion}

People in Kañaris experience illness, misfortune, and suffering as a result of both social and spiritual forces in their daily lives. In the previous chapter, we saw that individuals mitigate their vulnerability to fellow community members by keeping private knowledge hidden from public view, and not placing their trust in people who have proven themselves to be untrustworthy. In this chapter, we saw that people manage their vulnerability to the Devil, evil spirits, and the malevolent souls of the dead through annual and lifecycle rituals of protection, and by avoiding the places and times they are most likely to encounter such a spirit.

When a person encounters an evil spirit, they experience extreme dis-ease and sudden fright, which typically results in illness. This class of abnormal conditions must be treated by a remediera or sorcerer, local healing specialists who can call the victim's 
"shadow" soul back to them and extract the invisible illness-causing substance from their body.

These experiences index three categories of "evil" that are recognized through Kañarense praxis. Illness and misfortune are part of the existential evil of human suffering. When illness or misfortune is the result of the intentional action of either a human or non-human agent, people can assign responsibility for their suffering and evaluate the actions of the perpetrator as morally evil. And the invasive, contaminating illness itself is an invisible substance called "evil." In the following chapters, we will see that vulnerability to evil social and spiritual forces intersect in the practice of malicious sorcery. 


\section{Chapter 6: Illness, Healing, and Sorcery}

"I didn't believe in brujería before," says Andrés. "Until my daughter died."

I am shocked. I sit silently, waiting for Andrés to continue as he wishes. I hope I am respectful.

Andrés tells me it happened about ten years ago, before the birth of his youngest daughter. It was at the same time that his father, don Leonardo, had an operation to treat his cancer. Andrés spent all his savings to bring his father to a hospital in Lima to remove the tumor on his neck. The family had to cover the cost of travel, as well as the hospital bed, food, and various tests and medicines. Andrés accompanied his father to attend to him in the hospital.

A couple of days after his father's surgery, Andrés received a telephone call. His two-year-old daughter was very sick. He rushed back to Kañaris with great difficulty. A strike blocked the bus on the highway to Chiclayo, a twelve-hour journey from Lima at the best of times. Next he had to take another bus of five hours to Pucará, and then he either had to wait to find a truck going to Kañaris or hike eight hours up the mountains.

When he finally arrived home, Andrés took his daughter to a medical clinic in Ferreñafe, a small city close to Chiclayo. The medical doctors said that nothing was wrong with her, except that she needed more vitamins. But she was growing weaker daily, and Andrés knew something was wrong with his young daughter. He found one doctor who was "a little perceptive" (un poco curioso). The doctor told Andrés that he 
had "two problems." His father and his daughter were each gravely ill. Andrés wanted to save both of them, but he would only be able to save one.

"I was desperate, so I took my daughter to a maestro in Ferreñafe," says Andrés. At the time, he was determined not to believe in the superstition of sorcery. He was an educated young man who had completed high school and gone to teacher's college. But nothing else was working, so he tried a "master" or sorcerer.

"I held her in my arms throughout the night of the mesa." The sorcerer attended many other clients at the same ritual healing session. Evidently the specialist had some renown, but he wasn't able to cure Andrés' daughter.

Finally, Andrés took her back to the hospital. Kañarenses avoid hospitals for several reasons - they are expensive, one doesn't know what the doctors are actually doing to the patient, and it's a place people associate with death.

A month or two went by. Andrés was distraught. His daughter was not improving, despite the medicines the doctors prescribed. One night he had a dream about a certain flower called "aya rosa" (soul flower). ${ }^{13}$ It is a yellow or orange coloured flower that resembles a marigold. People in Kañaris use garlands of these flowers for ritual occasions: to adorn the litters of saints during their festival days, ritual tables during the wake for a recently deceased person, cemetery crosses during All Souls' Day, and crosses placed over the lintel of the front door of houses during Holy Week.

In his dream, the flower was dry, and fell apart in his hand. He knew this was a sign of impending death, but whose? His daughter lying in a hospital bed in Ferreñafe, or his father, whom he had left in Lima?

\footnotetext{
${ }^{13}$ According to Quesada Castillo, aya means "cadaver," as well as the soul commonly called ánima in the southern Andes, the "spirit of the dying person that wanders the world" (1976: 30).
} 
"I sat with my daughter day and night." He didn't want to leave her alone for a moment. She was so young.

Nevertheless, one day Andrés had to go to an office in Ferreñafe to apply for a teaching position. While he was waiting in line, he felt uneasy. He left for the hospital, and when he arrived the doctors told him his daughter had just died.

He went to see his daughter's body in the morgue. All he could do was weep.

Then he realized he had to arrange to get his daughter's body out of the hospital as soon as possible. He didn't want the doctors to do a post-mortem examination of the body. Who knows what they would do to it. Maybe he would never get her back in one piece.

This was difficult to do. An officer said the child had died of neglect, and he was going to report Andrés to the authorities if he didn't pay a fine. Andrés didn't have any money left to pay off the corrupt official.

Luckily, he met someone who helped him. A young man at the morgue saw him crying. This man was the morgue director's son, and he convinced the corrupt officer to release the body of Andrés' daughter.

Andrés bought a little casket and buried her in a concrete niche in the cemetery in Ferreñafe. He bought another casket in which he placed his daughter's clothes and other belongings, and he brought this to Kañaris to bury in the cemetery there.

It was a terrible story that Andrés told with his characteristic composure and calm. He never definitively told me what his daughter died of. When he brought up this story on other occasions, he suggested that she was attacked by an evil spirit (malo espiritu). 
Another time, Andrés recounted this story to a sorcerer in the morning after a mesa ceremony. I felt he told the story then to reflect on a personal turning point, when he began to believe in brujería (sorcery) after all. The sorcerer agreed that when one has certain illnesses, medicine will do nothing. One can die without the curative treatment of brujería.

\section{Brujería and healing}

Andrés' personal narration of the tragic loss of his daughter points to several important elements of sorcery or brujería in Kañaris. In this section, I start with a brief overview of the local medical system, suggesting why Andrés came to believe his daughter's illness could not be cured by biomedicine. I discuss the different therapeutic and curative treatments Andrés attempted, and reflect on his possible interpretations of their outcomes. Then I turn to why brujeria exists in Kañaris as both a genre of healing and a ritual practice. I argue that it matters to community members not because of their "belief," or even because of its experiential efficacy, but because in the process of diagnosing illness due to witchcraft, people learn something about themselves in relation to others. In the rest of the chapter, I outline the fundamental ontological understandings at work in brujeria. This allows us to examine a key process that is at stake in the local context - how people attribute responsibility for sorcery illness. 


\section{Medical pluralism in Kañaris}

Like many communities throughout the Andes, people in Kañaris accommodate medical pluralism, or the co-existence and validity of multiple medical traditions (see Crandon-Malamud 1991: 23-24; Koss-Chioino et al. 2003). For some illnesses, people can choose among several options. For others, only a specific form of treatment will cure the condition and heal the afflicted person.

Throughout this dissertation, I use "illness," "sickness," and "disease" interchangeably. I am aware of the rich debate in medical anthropology regarding the distinct experiential and pragmatic fields these concepts refer to. I am inclined to follow medical anthropologists such as Byron J. Good and Arthur Kleinman, who define "illness" as the culturally structured perception and experience of abnormal states of being that prevent a individual from carrying out their daily activities; "disease" as the interpretive movement by which experiential abnormalities become objects of medical knowledge and practice; and "sickness" as the process through which these disorders are understood in relation to macrosocial forces (Kleinman 1988: 3-6; Good 1994: 52-56; see also Young 1982). While I favour the terms illness and sickness over disease, a strong distinction among these concepts is not important to my analysis.

I realize some medical anthropologists also distinguish between "healing" (which addresses and resolves the culturally contingent circumstances of illness), and "curing" (which treats what people in a particular culture consider to be the naturally occurring biophysical phenomenon of disease) (see Kleinman 1973: 209-210; Waldram 1999: 604606; Young 1982: 265-266). However, while people in Kañaris clearly distinguish between different factors that cause abnormalities in the total person - in their physical, 
spiritual, and social aspects -, these conditions are encompassed by the blanket term for both illness and disease, "enfermedad." In addition, the practices that address and resolve these conditions of ill-being are intended to both heal and cure, "curar." For people in Kañaris, healing is indicated when the symptoms stop, the afflicted person can resume his or her daily tasks and responsibilities, and their activities return to their normal productivity.

Since I am interested in the local understanding of suffering and the practices by which people restore their normative state of well-being, I have not found it helpful to make strong analytical distinctions between illness and disease, healing and curing. However, George Foster's (1976) distinction between "naturalistic" and "personalistic" causal factors is helpful to my analysis. This is because the local medical system also recognizes different agents that cause illness and ill-being, with distinct genres of healing that are appropriate to address each broad type of causal factor. There is some overlap, but as the severity of the illness increases, so does the specialization of the treatment.

Symptoms of minor illnesses treatable by both local and non-local medical traditions include headaches, joint and muscle pain, skin irritations, coughs, fevers, nausea, and diarrhea. Community members suggest that such conditions are the result of either everyday strain on the body or "infections." This class of illness results from exposure to environmental elements or, implicitly, microscopic organisms. In other words, locals attribute these conditions of ill-being to "naturalistic" causes - outcomes due to "natural forces or conditions" rather than a result of intentional action (Foster 1976: 775). The causative agent is not internally motivated to produce illness in a particular person, and the person can prevent the condition by avoiding those behaviors 
or contexts that are known to result in illness, such as bodily exposure to environmental extremes of hot and cold (see Foster 1976: 775, 778-780).

In Kañaris, conditions due to "naturalistic" causal factors primarily affect the body. People recognize both herbal remedies and over-the-counter pharmaceuticals as valid curative responses to minor bodily illnesses such as colds and non-life threatening infections. If the "disease" is more serious, a doctor at the local medical clinic may refer them to another biomedical specialist in the city. Alternatively, people can seek diagnosis for their condition through a remediera, diviner, or other local specialist. For example, one community member was a well-known pulsero, someone who diagnoses illness through the client's pulse. This same man worked as a technician at the local medical post, and told me he had worked there since it opened in the 1980s.

Nevertheless, community members acknowledge that the most serious physical conditions of ill-being or disease must be treated by advanced medical doctors in the city. For example, Andres' father sought biomedical treatment to remove a cancerous tumour. I personally knew one other community member who had surgery in an urban hospital, and people told me of other occasions when they consulted medical doctors. This indicates that in the logic of the local medical system, the most serious illnesses due to "naturalistic" factors must be treated by the most advanced biomedical specialists.

Community members refer to this clinical field of practice and knowledge as "medicine" (medicina), and their customary curative practices not recognized by doctors and nurses as "traditional medicine" (medicina tradicional). For the sake of clarity, I refer to the clinical practice as biomedicine, a term that is intended to acknowledge the cosmopolitan trajectory and biophysical focus of Western medicine (see Leslie 1976). 
Yet people in Kañaris also recognize illnesses that have another type of origin. They come with sudden and distinct pain in specific regions of the body, they persist despite other forms of medical intervention, and their symptoms are indicated in the total physical, social, and spiritual situation of the person. This class of ill-being has been caused by the purposeful intervention of a malevolent spirit such as a malo espiritu, or the malicious ritual actions of other people - that is, witchcraft. In other words, community members attribute such illnesses to a "personalistic" causative agent. With "personalistic" illnesses, the afflicted person is a victim of aggression "directed specifically against him" (Foster 1976: 775). The illness is not a result of "accident or chance"; a particular person suffers a specific illness at a certain time because a human, non-human entity, or supernatural being has attacked, punished, or otherwise addressed the victim (Ibid.).

From the local medical perspective, the victim's pain and distress are bodily and embodied manifestations of an underlying condition affecting the non-corporeal parts of the person. The curative treatment must address this underlying condition in order to heal the illness. As we saw in the case of Andres' daughter, biomedicine cannot treat the noncorporeal parts of the person. This is the exclusive domain of local healing specialists such as remedieras, "soul-callers," and sorcerers. Sorcerers treat the most serious types of "personalistic" illnesses, those due to the power of encantos. While the encantos are distinct from malos espiritus, diablos, and the wandering souls of the dead, they are all spiritual entities cause illness by acting on a person's "shadow," or sombra.

Community members categorically told me that biomedicine cannot cure conditions such as susto and "the wind of the dead." "Doctors don't know about it," they 
say. "Doctors can't see it, and they can't cure it." It is not simply that biomedical doctors do not recognize "cultural syndromes" such as susto. It is that biomedicine only treats the body, and not the immaterial parts of the person, such as their shadow-soul or sombra. Even though biomedicine does not recognize the sombra as an integral part of the person, community members know it exists, for its loss is followed by significantly abnormal behaviour, debilitating illness, and eventually death.

The interpretive arc of an illness

When Andrés' daughter was gravely ill, he consulted medical doctors and a sorcerer on the coast. When she did not get better, he took her to a hospital, but still her condition worsened. Maybe she had an illness that biomedicine could indeed recognize and cure, but the doctors were not attentive or competent enough to diagnose it. Perhaps they thought her illness was "psychosomatic" or "sociosomatic" (see Kleinman \& Becker 1998), and therefore not worth taking seriously. Nevertheless, her illness had undeniable, material consequences. It eventually resulted in her death.

After this event, Andrés re-evaluated his understanding of his daughter's illness. He had hoped that biomedicine would cure her, yet it failed. It seems he came to believe that her illness was not due to a "naturalistic" cause after all, but instead a "personalistic" agent. He suggested an evil spirit had attacked an invisible part of her person, her "shadow" or sombra. It is possible that Andrés held himself partially responsible for his daughter's death, since he did not seek additional treatment to "call" her sombra back to her. Perhaps if Andrés were faced with a similar situation today, he would consult another sorcerer, not out of "desperation," but with "faith." 
While Andrés did take his daughter to a sorcerer in Ferreñafe, the mesa did not cure her. Perhaps the coastal sorcerer was incompetent or inattentive, and did not properly diagnose her condition. Perhaps he was not a "real" healer at all, but a fake who puts on a show for gullible people who pay him. Andrés did not tell me what he thought of this sorcerer. But based on what other people told me about their suspicions of sorcerers, incompetency or fraudulence is a likely interpretation of why the coastal sorcerer did not cure her.

Andrés told me this story in part because he wanted to demonstrate that he did not believe in brujeria before he faced this crisis. His actions also indicate that his interpretation of his daughter's condition changed over the course of her illness. His account suggests that there is a gap between conscious reasoning and unreflexive conviction. The unspoken assumption about brujeria is that it does not matter if you "believe" in it or not; it works in appropriate contexts because it is "real."

Andrés' personal narration also points to a key characteristic of local medical belief: the "true" cause of the person's illness is indicated when a given treatment "works." If the condition persists or worsens despite various medical interventions, it is because they have failed to address the specific causal agent. Andrés' account is representative of many other "narratives" of illness I heard in Kañaris (see also Kleinman 1988; Mattingly 1994; Mattingly \& Garro 2000), although usually not with such a tragic ending.

Community members typically try several curative responses until they find one that "works" to heal them of a given illness. Within the logic of the local medical system, only particular types of healers can treat certain conditions. It is important to determine 
the cause of the illness in order to seek the appropriate method of treatment. But since the assessment of curative efficacy is pragmatic and retrospective - a given treatment was the correct one if it "worked" to resolve the symptoms and allow the client to return to their normal life - people seek out multiple medical treatments one after the other.

People often seek diagnosis and low-investment medical treatment from both local healers and biomedical practitioners at the same time. Herbal remedies and overthe-counter pharmaceuticals are not difficult to obtain, and they do not cost very much. Better to "cover all the bases" when one can. If an individual suspects their illness may not be due to physical conditions, but instead a spiritual entity, they will consult a "more advanced" local healer, such as a remediera or someone who "calls souls." Both remedieras and "soul-callers" can cure illnesses attributed to the personal intentions of spiritual entities such as malos espiritus. If this specialist cannot cure the client's illness, it is likely caused by a more powerful non-human entity, an encanto.

Traditional medicine and biomedicine are compatible with one another in Kañaris. What is not possible in local understanding is for the advanced specialist of one tradition to treat an illness that can only be addressed by the other. Only doctors perform surgery to remove tumors, and only sorcerers communicate with the encantos.

\section{From illness to brujería}

In a pivotal article in medical anthropology in the Andes, Libbet Crandon asks why the illness called susto exists throughout Latin America. Crandon succinctly summarizes susto as the separation of a person's soul from their body due to fright, which results in a range of symptoms, including: 
... restlessness in sleep, listlessness, loss of appetite, weight loss, disinterest in dress and personal hygiene [sic], loss of energy and strength, depression, introversion, paleness, and lethargy. It can also present with high fever, diarrhea, and vomiting, and occasionally leads to paralysis and convulsions. In some populations it can be fatal. (Crandon 1983: 156)

Crandon urges anthropologists to look beyond biological, psychological, and psychosocial explanations for “cultural syndromes" such as susto (1983: 153-154; for “cultural syndromes” see Hahn 1985; Hughes 1998; Nichter 2010; Simons \& Hughes 1985). She provides an alternative model of inquiry to restructure the analytical question from "What is it?" to "Why is it?" (Crandon 1983: 154). As an interpretive anthropologist, Crandon is interested in what significance an illness has for people in a given community, and why it exists as a diagnosable condition. Therefore she asks not simply "why certain classes of people are diagnosed as suffering from susto rather than other classes of people," but "why certain classes of people are diagnosed as suffering from susto rather than from some other illness category" (Ibid.).

Ultimately, Crandon argues that susto is significant for the people in the highland Bolivian community where she worked not because of its "cause" (as many other commentators assume), but because of the process of "diagnosis" (1983: 161). In a context of medical pluralism, in which locals recognize the validity of multiple medical epistemologies, people are symbolically positioned in specific ways when they diagnose a condition that is only treatable by one medical tradition rather than another. For Crandon, the signification has to do with "personal identity, ethnic identity, political strategies, and economic possibilities" (Ibid.).

A similar argument could be made for Kañaris, but I am not primarily interested in community members' individual or collective identities. The thrust of this dissertation, 
rather, is to examine social relations within the community, rather than relations between this community and others. We have been exploring the internal dynamics of the community, how people account for and address their episodic experiences of suffering, how they evaluate the actions of fellow community members, and the role of sorcery in this.

Crandon's argument is enlightening, however, because just as Crandon asks, “Why susto?” I ask "Why brujeria?” Like Crandon, I want to move beyond questions such as "What does brujería do?" and "When is it appropriate to seek healing through brujería?" I instead ask why brujería persists despite community members' stated incredulity and demonstrative desire to distance themselves from a practice that others (and to a certain extent themselves) regard as morally questionable and irrationally superstitious. To take up a question posed by Byron J. Good in his reading of E.E. EvansPritchard's work on Zande witchcraft, "How can a set of beliefs and institutions which are so obviously false (propositionally) be maintained for such long periods of time by persons who in much of their lives are so reasonable?" (Good 1994: 12).

I contend that brujeria persists and matters to people in Kañaris, but not because of the "cause" of the illness, or the "efficacy" of the healing, or even the underlying "reality" that the practice indexes, in either an experiential or metaphysical sense. It matters because in the course of a mesa ceremony, individuals come to know something about themselves in relation to other community members. Brujería is a practical and discursive field in which relations within the community of Kañaris come to the foreground. When an individual or their family members visit a sorcerer, they hope to be "healed" and return to their normal state of functioning. But they also expect to ascertain 
who wishes them ill and whom they cannot trust. This knowledge is not so much disclosed by the sorcerer's diagnosis, as confirmed in the very act of consulting a sorcerer. The client already suspects that a fellow community member has perpetrated witchcraft against them. They seek the sorcerer's verification of their suspicion of which community member is morally responsible for their illness or misfortune in this particular case. I believe people seek this verification because of their heightened sense of vulnerability to social others. Once a person knows who has secretly harmed them, they will be able to modify their future interactions with the perpetrator in order to mitigate this vulnerability.

To the best of my knowledge, consultations with sorcerers do not typically result in counter-attack through vengeful witchcraft (compare Evans-Pritchard 1976: 5-7). It seems if this were the case, there should be many more reported instances of illness due to witchcraft, or some other way in which attack and counter-attack were indexed in everyday life. In addition, if counter-witchcraft were very common in Kañaris, it seems there should be some moral justification for it. Yet although people told me about longstanding grudges and personal differences, I did not hear of any instances of counterwitchcraft. And when the topic did come up, my interlocutor indicated that counter-attack is just as morally despicable as the initial round of witchcraft.

For example, someone told me that several years ago, their father visited a sorcerer and learned who had done witchcraft against their family, which had led to the failure of a family business. The sorcerer said he could then attack the individual identified through witchcraft. The father declined, saying, "it was enough to know who had done it." I assume the father and his family then re-evaluated their opinions of the 
perpetrator and their family, and modified their interactions with the people who envied them. This would be valuable information in Kañaris, were locals are concerned about the trustworthiness of fellow community members. From the perspective of my interlocutors, the question of trustworthiness and the issue of vulnerability to social others is real and present, as indicated by the earlier story of my friend and her questionable cousin.

Brujeria is a genre of healing illnesses attributed to the power of the encantos, and people would not go to sorcerers if they did not hope to be cured of these conditions. As we will see in the following chapter, people can also visit sorcerers in order to modify their state of "luck" and increase their productive capacities. Nevertheless, I contend that the social significance of brujeria lies in what the diagnosis of an illness only treatable by sorcerers tells the client about their relations to fellow community members.

From this perspective, it is especially significant that, first, locals always say that witchcraft is perpetrated by a fellow community member, and second, people never publically accuse the individuals they identify as the perpetrator. Nevertheless, the victim modifies their evaluations of and interactions with him or her, as we saw in the chapter about trust and secrecy. I have already outlined the social concerns and understandings that inform this strategy of managing vulnerability to fellow community members. Now we are ready to examine the underlying ontological assumptions of how brujeria works.

\section{An ontology of brujería}

Brujeria is the two-sided practice that encompasses both causing and curing illness with the power of the encantos. In this section, I situate this process in the pre- 
given understandings of the lived Kañarense world. While these details are not necessarily consciously present to practitioners and participants when they experience illness or healing through brujeria, they are necessary for an outside analyst to approach the distinctly local conception of the world. I draw upon both the insights Andrés and other community members provided me with, and the existing ethnographic literature on brujeria in the northern Peruvian Andes. In particular, I refer to the work of Mario Polia, an Italian anthropologist who has conducted ethnographic fieldwork on brujeria in the highlands of the region of Piura for over thirty years (see Polia 1989a, 1989b, 1994a, 1994b, 1996, 2001, 2005, 2006).

According to Polia, the local ideas of being that underlie brujería point to a "profound interrelation between the visible and 'invisible' world" (Polia 1996: 154). That which exists exceeds sensorial experience. An invisible, supernatural world parallels this one. Although brujeria is meaningful for participants because of its social context, much of the sorcerer's work takes place in this invisible, parallel world.

\section{The parallel world of the encantos}

The encantos exist in this world as physical mountains, lakes, and other landforms. But they also exist in a hidden, "inner" world that is normally invisible to people. As Polia notes, this hidden world resonates with the Andean notion of " $u k h u$ pacha" (1996: 122). This is a space-time that is not just "below," but "within" the sensorially received human world. Although the notion has become associated with the Christian realm of "hell," the important thing for our purposes is that "ukhu pacha" is a hidden, "inner" world that contrasts with both this terrestrial world, "kay pacha," and the 
world above, "hanan pacha" (Polia 1996: 122; see also Allen 2002: 46-48; BouysseCassagne \& Harris 1987; Dransart 2006; Gose 2008: 294, 304-305; Platt 1983: 68-69n2, 1986: 242).

While I never heard anyone in Kañaris describe their understanding of the world in these classically Incan terms, in practice a local distinction exists between the apparent world of sensation that can be felt, heard, touched, smelled, and seen by anyone, and an invisible world that only a small number of people recognize. People in Kañaris rarely remark upon this distinction verbally. Nevertheless, it is articulated in the practice of brujeria, as well as the wider sphere of human encounters with spiritual entities.

The sorcerer is able to communicate with the encantos because he can intentionally and consciously enter the parallel world they inhabit. He does this especially when he undertakes sacred visioning while consuming psychotropic plants such as the cactus San Pedro. This particular northern Andean understanding resonates with Western Amazonia. For example, there shamans say ayahuasca reveals a hidden spiritual reality, or the "true" world, because it lifts the obscuring veil of the visible, or phenomologically received, world (see Harner 1972: 134). According to Polia, everyone has the potential to perceive the "true" reality of the invisible world, but few actually "see" it (1996: 136137). The special capacity of the sorcerer is to see the invisible world.

I am not sure how people in Kañaris envision the world of the encantos and spirits. Most of what I can say is based on inferences from what people told me, as well as the work of Polia (1996). I call it a parallel spiritual (or supernatural) world because it is an invisible world that exists alongside this one. The same landforms that look like mountains or lakes to our eyes have another world inside, with the rich lands and 
resources of the encantos. And the same people who are distinguished by their individual bodies and mannerisms in this world have other essential parts of their person in the unseen world.

Two invisible aspects of the person that Andrés often mentioned to me are the "soul" (alma) and the "shadow" (sombra). Andrés also used "spirit" (espíritu) as a shifting term to sometimes refer to the soul and other times the shadow. As Polia indicates, this should not be mistaken for the soul and shadow being equivalent to one another (1996: 153). For the sake of clarity, I restrict "spirit" for the general category of things that pertain to the unseen supernatural world that exists alongside the everyday world.

"Shadow" and "soul"

As I suggested earlier, the shadow is distinct from the soul. The deceased's soul leaves this world when the person dies. The person's soul immediately goes to the distant realm of God to be judged for the sins they committed in life (Polia 1996: 161). Only people - and specifically, baptized people - have souls (Polia 1996: 163). Certain nonhuman entities and sacred objects have "shadows," but none of them have "souls." These are the mountains and lakes that are the encantos, the bones and ruins of the pre-Christian dead (gentiles), the power-objects the sorcerer uses to extract illness, and the psychotropic plants he consumes (Polia 1996: 155, 159-163).

The "shadow" or sombra, in contrast, survives in this world after death. It remains attached to the physical remains of the person - their bones and burial site, their home, and the clothing, tools, and other things that belonged to them (Polia 1996: 158-159). In 
Kañaris, this is indicated by extended funerary rites. For example, on the six-month anniversary of the death of Andrés' father, his family held a vigil in his parent's home. They set up an altar in the front room and lit candles in his name. They gathered all his clothing and tools around the altar. Afterwards, I was told, they would wash them. I had to leave the next day, so I did not see what the family did with his belongings. Perhaps they distributed them among his grown children or put them in storage. The purpose of this second funeral is to cleanse and disperse the things that the deceased's sombra remains attached to, so that it can be freed to journey to the spirit world (see also Gose 1994: 114-140, 2008: 309-319 on funerary rites and the fate of the non-material parts of the person after death in the southern Andes).

The sorcerer is distinguished from lay people by his ability to purposefully separate his sombra from his body and enter the world of the encantos (Polia 1996: 108109, 153). The sombra is the person's unseen, "immaterial double" (Polia 1996: 154). Like a visible shadow cast by light, the spiritual shadow physically resembles the person or thing it is connected to (Ibid.). It also has the person's non-physical characteristics, such as "goodness or wickedness, strength, wisdom, beauty or ugliness" (Polia 1996: 155).

According to Polia, the sombra is responsible for a person's character and personality, and it is connected to their ability to think and act (1996: 156). When a person's sombra is separated from their body, it "maintains an autonomous consciousness and identity" (Polia 1996: 155). It can act independently of the person, such as travelling "through time and space" to "instantly arrive at faraway places" (Ibid.). The sorcerer does this when he deliberately enters the world of the encantos (see Polia 1996: 134-136, 153). 
Through the shamanic actions of his sombra, the sorcerer is able to communicate with the encantos, and they "show" or "tell" him how to diagnose and cure his client's illness.

Unlike sorcerers, lay people cannot control the actions of their separated sombras, which continue to exist, act, and feel independent of their bodies (Polia 1996: 153).

Crucially, non-specialists cannot make their sombra return to them. A person can survive for a time without their sombra, as when dreaming (Polia 1996: 165). But the longer it is away from their body, the more weak and ill they will become (Polia 1996: 156). The separation of the sombra from the person is dangerous not only because it is "outside" the body, but outside the field of a person's control, reason, and sensorial consciousness (Polia 1996: 166). A person who has lost their sombra has also lost their faculty for "reason," and they will behave abnormally (Polia 1996: 156, 162). If it is not returned to them, the person will eventually die (Polia 1996: 156). The sombra is not merely an icon and index of the physical person, but an essential aspect of the embodied subject.

The sombra is a spiritual or immaterial part of the person that is not visible in this world. However, it maintains an unseen but physically manifested connection to the body even when it is separated from the person. That is, actions carried out on the sombra produce a homologous effect in the body of the person (Polia 1996: 154, 156). For example, if the sombra is injured in the world of the encantos, the person in this world will experience an illness or wound in a corresponding region of their body (Ibid.). When the sombra is kidnapped, contaminated, or otherwise harmed, the person is similarly afflicted with bodily illness or emotional distress. The victim can also experience suffering in the material and social extensions of their person - for example, in the condition of their crops and animals, or the state of their family and household relations. 
Polia argues that the illnesses treated by sorcerers ultimately have to do with the state of the client's sombra (1996: 469-471). A person's sombra can be "frightened" by a natural event or traumatic experience (Polia 1996: 164), such as when they are startled by a sudden fall or a creepy walk down a nighttime road. In this case, the sombra "invariably falls under the power of an entity from the mythical ancestral world," such as an encanto or malo espiritu (Ibid.). An encanto can also be provoked to “grab” a person's sombra, for example if the person sleeps close to the place where it resides, or breaks a ritual taboo (Ibid.). A sorcerer practicing "love magic" captures a person's sombra to overcome their will and "fall in love" with their client (Ibid.). Similarly, a sorcerer practicing witchcraft can "kidnap" a person's sombra to cause bodily illness and eventual death (Ibid.). In each of these cases, another sorcerer must "call" the sombra back to the victim's body, and offer ritual payments to the spiritual entity as compensation in order to cure their condition.

Encantos can also "contaminate" a person's sombra, which causes "physical and/or psychic disturbances" - that is, illness (Polia 1996: 164-165, 469). This illness occurs not because a person's sombra has been kidnapped, but because it has come into contact with the raw power of a spiritual entity. For example, Andrés told me, a sorcerer practicing witchcraft directs the power of the malevolent pre-Christian spirits called gentiles towards a witchcraft bundle with the intent of causing damaging illness (daño). When the victim comes into physical contact with this object, the power of the gentiles transfers from the witcheraft bundle to the person's sombra. Their sombra is now "contaminated" with the sickening power of the gentiles, and the person must visit a sorcerer to "extract" this invisible substance from their body in order to be cured. 
The power of the encantos

The encantos, the power-objects connected to them, and plants such as San Pedro have their own sombras that exist in the parallel spiritual world, where they take a human or animal form (see Polia 1996: 104-105, 108, 133). By Polia's definition, all of the objects on a sorcerer's ritual table and the spiritual entities he communicates with are encantos (1996: 205, 348). In my experience, people in Kañaris only use the term encantos to refer to certain named and individualized mountains, lakes, and waterfalls. Therefore, I have restricted my definition of encantos to these sacred places. At the same time, the local practice of brujeria also points to the sorcerer's power-objects and psychotropic plants as special categories of things. They are sacred, not only set apart from the everyday world, but with the potential to sicken or disturb a person who does not have individual ritual "pacts" with them, as the sorcerer does. Therefore, I consider both these sacred objects and the place-based spirits called encantos to posses "power" or “virtue" (Polia 1996: 159-163, 294-295).

By means of their sombra, the encanto or power-object is able to act of its own free will and produce a particular effect. In other words, entities with sombras are attributed with an individualized agency. Polia indicates this when he says:

The first fundamental consideration is that the concept of the "shadow" does not just refer to human persons, but also extends to animals, to plants, to things, or, at least, to things endowed with power and which for this reason are defined as "living." To talk of the Andean world in terms of "inanimate objects" is, therefore, an inappropriate expression. (1996: 159) 
The encantos, power-objects, and sacred plants are not simply able to produce an effect. Crucially, this effect is a result of their internally generated motivation to act. As I will elaborate below, these non-human entities and "living" objects therefore can be described as "agents" - that is, as animated things with the power to act. In a fundamental sense, this is what Polia is pointing to when he says that encantos, power-objects and sacred plants have "power" or "virtue." In this sense, virtue is not a moral quality, but refers to an entity's capacity to do something. By virtue of their internal motivation, they are able to affect people.

The sorcerer's power-objects - such as the sacred rocks, swords, and staffs on his ritual table - are not merely tools he uses for healing, or mediating objects that provide a conduit to particular mountains and lakes. An immaterial aspect of the encanto is always present in them. The sorcerer must "wake them up" at the beginning of the mesa ceremony, and then "close" them at the end. A lay person who touches the rocks, swords, or staffs that have not been properly cleansed and wrapped up after the mesa will become "contaminated" with the power of the encanto dormant in them.

In this sense, the "power" of the encantos is an invisible, immaterial substance that is embodied in particular rocks, swords, and staffs. Through the physical contact of the body and the sacred object, the power of the encantos can transfer to and from a person and a place-based spirit. Each encanto has its own power-substance, and after a healing ceremony, the sorcerer must send it back to its supernatural source so that it does not contaminate and sicken bystanders.

The power of the encantos flows like an electrical current. Under normal conditions, lay people cannot perceive this power by sight, sound, smell, taste, or touch. 
The possible exception to this is during the mesa healing ceremony, when people sometimes see "sparks" emanating from the sorcerer's power-objects. Yet people know the power of the encantos exists because it produces "experientially real" effects.

Moreover, this power is not inherently "good" or "evil." People in Kañaris do not assess the power of individual encantos in moral terms. Nevertheless, the power of the encantos always has the potential to bring suffering and misfortune, or benefit or and good fortune. As Polia says, the same encantos have a "positive" and "negative" potential (1996: 118). In its raw, unmediated form, this power is inherently dangerous to lay people. On the rare occasions when people come into direct contact with the spirit of an encanto - for example, when they encounter its human incarnation on a country road at night - they always fall ill or face grave danger.

The sorcerer mediates and domesticates the power of the encantos on behalf of lay people, directing it towards certain goals. For example, sorcerers use the same power of the encantos to both cause and cure sorcery illness. In its mediated form, this power has one or another effect according to the will and intention of the ritual specialist. The power of an encanto is sickening or healing according to the malevolent or benevolent intent by which the sorcerer directs it towards an individual.

\section{The power of the sorcerer}

The sorcerer himself also has "power," but it is not the same as the power of the encantos. The sorcerer does not possess an invisible substance that can bring either health or illness. Instead, the power of the sorcerer is in his "virtuous sight" (Polia 1996: 133) his shamanic visioning - and his ability to communicate directly with the encantos. As 
we have seen, the sorcerer is able to voluntarily enter the "hidden" world of the encantos by separating his sombra from his body. But unlike lay people, the ritual specialist is maintains a conscious connection to his spiritual double, and therefore he is able to both act in the parallel world of the encantos and bring back knowledge to this world.

The sorcerer consumes San Pedro because this facilitates the voluntary separation of his sombra from his body and his communication with the encantos (see Polia 1996: 108-109, 305-306). However, according to Polia, the sorcerer's power is not in the hallucinations brought on by San Pedro and other psychotropic plants. Rather, his "power" is in the "quality of the vision" and the "capacity to interpret" what he sees (Polia 1996: 109). When the sorcerer consumes sacred plants, he enters the world of the encantos and talks to the human or animal forms of the mountains, lakes, power-objects, and sacred plants. These "enchantments" - that is, encantos - tell the sorcerer how to cure his client (Polia 1996: 104-105, 305-306).

San Pedro and other psychotropic plants do not bestow the capacity to "see" the "true" spiritual reality within the everyday world. Instead, the sacred plants "awaken" this capacity in predisposed individuals (Polia 1996: 130). The sorcerer's "virtue" of mystical sight is his divinely conferred power, or "charisma" (Ibid.). This is a quality that differentiates the sorcerer from lay people. It is a "gift from God" - that is, an innate talent - and it cannot be learned, created, or transmitted (Ibid.). Thus Polia calls the sorcerer's mystical vision his "sight by virtue [of this divinely bestowed gift]" (vista en virtud) (1996: 133). 
The sorcerer's power is in his divinely bestowed ability to "see" and act in the parallel world of the encantos. In contrast, the power of the encantos is in the invisible substance that has the equal potential to produce positive and negative effects in people.

\section{Agency, subjectivity, responsibility}

Who, or what, is responsible for causing the types of illness treated by brujeria? This is a key question for both community members and the outside analyst. There is no simple answer. The encantos, the sorcerer, and his client all have some responsibility for witchcraft illness. On one hand, these bodily illnesses and other conditions of ill-being

are connected to the power of the encantos. An encanto has contaminated, frightened, or kidnapped an invisible aspect of the afflicted person: their sombra or shadow. On the other hand, encantos rarely cause illness in lay people of their own accord. Encantos do not have personal relationships with lay people, and tend to ignore them in everyday life. When their power produces illness and misfortune in a particular person, this is almost always because of how it has been mediated and directed by a human agent.

As we have seen, illness attributed to the power of the encantos occurs through direct contact, accidental contamination, or malicious witchcraft. In terms of witchcraft, the primary concern of community members lies with the malevolent intent of ritual actions to cause harmful and damaging illness and misfortune. Indeed, the practice of witchcraft and its treatment through ritual healing (that is, brujería), make healing sorcerers necessary in the first place.

Witchcraft only occurs when a client pays an unscrupulous sorcerer to do it. The sorcerer causes illness with the power of the encantos and their evil counterparts, the 
gentiles. A maestro heals with the power of these same spiritual entities. He heals not with an overarching power found in "the encantos" in general, but rather with the power originating in the specific encanto that caused the illness in the first place.

Yet in highland communities such as Kañaris, encantos are not just "forces of nature" (compare Joralemon \& Sharon 1993: 150). Encantos animate the local landscape. People anthropomorphize encantos by attributing them with human characteristics and giving them names. Named and anthropomorphized, specific encantos may choose to participate in a chain of cause and effect whose outcome is illness or healing. This is not obvious from the perspective of the lay person, since encantos rarely address them directly. But if we analyze what a sorcerer does to heal a person, then the encanto's agency becomes apparent. In relation to the sorcerer, an encanto chooses to participate in an event of its own free will.

While lay people do not have individual relationships with the encantos, sorcerers do. Sorcerers establish ritual relationships and sacred "pacts" with specific encantos (Polia 1996: 113, 166, 274-275). The sorcerer provides the encanto with offerings. For example, he blows sugar cane alcohol and floral waters over his ritual table as "refreshment" for the encantos during a mesa ceremony. In return, the encanto allows him to use its power for his client's benefit. If the sorcerer neglects to provide offerings for the encanto, the spiritual entity will harm him instead of helping him, by causing the sorcerer himself to become ill (see Polia 1996: 98-99). Nonetheless, the sorcerer does not simply use the power of the encantos as one would use a tool. He communicates with the encantos through his ritual offerings, through his sacred songs, and through the actions of his sombra in the invisible, parallel world they inhabit. 
When we look at encantos from the perspective of illness and healing in a lay person, they often appear as disinterested forces of nature. But when we consider encantos in relation to the conditions under which they become involved in a chain events - that is, through the mediation of a sorcerer - we can see locals implicitly attribute them with both agency and subjectivity. Yet although they are named and anthropomorphized, encantos do not act as human subjects with human interests.

If we take subjectivity to entail individual consciousness, a subject is someone who is self-aware, present to themselves, and who also understands other subjects to be conscious to themselves (see Csordas 2008: 112-113). This mutual recognition presupposes an essential similarity between "alter egos" (Csordas 2008: 112-113, 119). In the northern Peruvian Andes, this similarity is indicated through the attribution of a sombra in both humans and encantos.

The existing ethnographic record does not indicate whether or not encantos have awareness of themselves or the selves of others. However, based on what people in Kañaris told me, encantos do have self-generated intentions towards people, and act sometimes to human benefit and other times their detriment. This is most obviously illustrated in the ritual "pacts" that sorcerers have with specific encantos. It is also indicated in local myths in which lay people come into direct contact with the human incarnation of an encanto.

I consider the encantos to possess or display a limited degree of subjectivity. However, these spiritual entities and non-human agents are not "subjects" in the human sense. Encantos, power-objects, and sacred plants lack the "reason" (razón) that characterizes people (see Polia 1996: 163). They are "animated" entities and "living 
things" with sombras, but in local understanding, only people have the capacity for rational thought.

Subjectivity matters to people in Kañaris, but not because they are interested in defining what is human in contrast to the non-human, as we in the West are. Nor do community members seek to determine what they share in common with certain animals or plants, as the theory of "Amazonian perspectivism" implies (see Viveiros de Castro 1998). Rather, people are concerned about how non-human agents with a limited degree of subjectivity affect them. The capacity for a spiritual entity to act, and the ways that people hold them accountable for what results from these actions, does matter to people in the Andes.

In this section, I examine two kinds of agency displayed by encantos. In the first sense of agency, encantos have the capacity to exert power and produce a predictable effect. This effect is not the result of the encanto's intention to produce a given outcome. Instead, people hold another actor or agent accountable for the outcome of illness or healing. In cases such as witchcraft, responsibility for sorcery illness is distributed among or shared by two or more agents. Therefore, I call this "distributed agency."14

Yet this does not mean that encantos never have any intentions towards people. In the second sense of agency, encantos can act according to their own free will. Since encantos have their own shadows, they are not "inanimate objects"; they are "living things" with their own knowledge and volition. Encantos address sorcerers directly, and on rare occasions also address lay people. They can choose to help or harm people, and encantos can be held responsible for what results from their action. I call this "intentional

\footnotetext{
${ }^{14}$ I am grateful to Kristin Bright for suggesting the term "distributed agency" to me.
} 
agency." It refers an individual entity's capacity for action of their own free will relatively independent of larger structures.

Once I have outlined these two aspects of agency in encantos, we will return to what really matters to people in Kañaris: the question of responsibility for sorcery illness.

\section{Distributed agency}

In the first sense of “distributed agency,” I draw on James Laidlaw’s (2010) discussion of agency as the capacity for someone or something to exert power and produce a predictable effect. In Laidlaw's sense, agency is not "an inherent quality of which individuals may have more or less" (Laidlaw 2010: 147). Rather, agency is attributed through an interpretive movement that assigns responsibility for an outcome (Laidlaw 2010: 147ff).

Let me offer an analogy to explain how Laidlaw's discussion is relevant. If you stick your hand in a fire, you can expect the fire will burn you. This does not mean the fire had the intention to burn you, and this is why the fire produced the outcome of a burnt hand. You put your hand in the fire, and while you may or may not have wanted to burn your hand, the fire burned it nonetheless. Fire's nature is to burn things, but it does not possess the intention to burn your hand. The fire does not want anything at all, for it has no free will or consciousness by which to direct such an intention. Rather, it displays agency in Laidlaw's alternative sense: fire predictably burns. Through fire's capacity to exert power and produce an effect, your hand was burned.

Similarly, encantos do not typically "want" to cause illness or healing in a person.

The power of the encanto is mediated by the ritual actions of a specialist, a sorcerer. The 
encanto does not intend its power to make the sorcerer's client ill or well. During a mesa, the encanto is not interacting with the client or lay person; it is only communicating with the sorcerer. It is the sorcerer who directs the encanto's power according to his will and intention. Thus the encanto's power is sickening in one context and healing in another. This is not a result of either the encanto's intention towards the lay person, or an inherent quality of the encanto itself - that is, as a "good" or "bad" spiritual entity. The encanto's power results in illness or healing because of the way it has been intentionally directed according to the will of the sorcerer.

In the case of illness and healing effected through brujeria, the encanto is an essential participant in a chain of cause and effect that produces a predictable outcome. Yet people do not consider the encanto to be "responsible" for bringing about illness or healing in a particular person. In local opinion, the intention of the sorcerer and the client on whose behalf he acts is the socially relevant location of responsibility. In this instance, the encanto is displaying "distributed agency." Humans and the spiritual entity share the responsibility for the outcome of the encanto's power.

\section{Intentional agency}

Yet this is not always the case. It is too simplistic to categorize encantos as "subjectless" agents. Unlike fire, encantos are not "inanimate" objects. They occupy a distinct ontological category in the northern Peruvian Andes. Encantos do sometimes display an individual intention towards people. This is most evident in their relationships with sorcerers, with whom they have ritual "pacts." The encanto "permits" the sorcerer to use its power, and the sorcerer is obligated to provide the encanto with ritual offerings. 
The sorcerer can use the power only of those individual encantos with whom he has this special relationship. If the sorcerer neglects to provide the encanto with ritual offerings, the spiritual entity will retaliate and make him ill.

Lay people do not have ritual "pacts" with encantos, and so they cannot use this spiritual power cause or cure illness themselves. Nor are lay people able to voluntarily and consciously separate their sombras from their bodies to enter the invisible, parallel world to communicate with the sombras of the encantos. When a lay person does encounter the sombra or visible manifestation of an encanto, it is very dangerous. The person usually becomes ill as a result of this direct contact.

In these instances, the encanto expresses an intention towards a specific person. An encanto can "grab" the sombra of a person who has trespassed on their domain. For example, this can happen when the person fails to ask permission of the encanto to gather sacred herbs in its "secret garden." The encanto can "grant" permission to a person to mine, gather herbs, or pass over it.

In certain contexts, then, encantos demonstrate their capacity to act according to their self-generated intention and individual free will. They specifically intend to help or harm a person. In these cases, they display "intentional agency" - they produce an effect that arises from their personalized motivation. Are encantos then always responsible for the effects or outcomes of their spiritual power? Who or what do people hold accountable for illness and healing in brujeria? 


\section{Accountability}

People in Kañaris are not demonstrably interested in the agency or subjectivity of place-based spirits such as encantos. Yet this discussion is necessary to understand what does matter to them: determining who or what is responsible for illnesses treated by brujería. Occasionally, encantos cause illness in a specific person of their own volition that is, when the illness is an outcome of their "intentional agency." This is relatively rare, and when it does happen, the victim can visit a sorcerer to cure it. There are no reverberating consequences of this event for the afflicted person, other than the outcomes of the illness or misfortune itself. However, when the condition of ill-being is due to the ritual actions and intervention of another person, this has serious social consequences for the victim. In this case, the illness is the outcome of the "distributed agency" of the encanto and one or more human actors.

From the perspective of the application of the encanto's power, the spiritual entity has "caused" the illness in both these cases. The curative treatments through the sorcerer's performance in the mesa healing ceremony are also basically the same: the sorcerer "extracts" the invisible, sickening substance from the client's body and sends it back to its supernatural source.

Yet this tells us very little about the social significance of these types of illness. When an illness is the outcome of the "distributed agency" of an encanto, the sorcerer and his client are also responsible for the outcome. Indeed, although witchcraft illness could not be effected without the power of the encantos, and although witchcraft happens only when an evil sorcerer directs their power with the intention to cause damage, in the end witchcraft has been set into motion by a lay person who wishes to harm a fellow 
community member. It is the sorcerer's client who is the "socially real" perpetrator of witchcraft. Whenever community members told me about specific cases of witchcraft, their narratives emphasized determining who could be held accountable for contracting a sorcerer. After the diagnosing and curing illness, this is the most important thing that happens during the mesa healing ceremony.

Determining accountability for witchcraft illness is the most important social role that brujeria fulfills. Accountability refers to the ways people assign responsibility for a given outcome. The power of an encanto has made someone ill, but can they be held accountable for this effect? Yes and no. The encanto is responsible in some way, since an individual would not experience this type of illness if they did not come into contact with the invisible substance of their power. Usually, however, encantos do not "care" if a person is ill or healthy. The power of the encantos is necessary to bring about well-being or suffering through brujeria, but their intention is not. It is because of the will and desire of social others, whose intentions are deliberately set in motion through the ritual actions of brujeria, that produces health or illness, good luck or misfortune, life or death in a specific person. The effects the encantos produce are not always a direct result of their intentional agency or action. Rather, their effect is an outcome of the intention of the sorcerer, and the client on whose behalf he acts.

I contend that determining social accountability and moral responsibility for witchcraft illness is important to people in Kañaris because of the vulnerability they feel towards fellow community members. When an individual ascertains who has perpetrated witchcraft against them, they do not use this information to do counter-sorcery or publically accuse the person who has proven to be their enemy. Rather, as we saw in the 
previous examples of my friend and her questionable cousin, and the man whose family business failed, people quietly modify their social interactions with the perpetrator in order to mitigate and manage their potential social, political, economic, and spiritual vulnerabilities in relation to them.

\section{Chapter conclusion}

Brujeria or sorcery is a genre of healing that exists alongside traditional medicine and biomedicine. It fills a distinct role in the local medical system, as it specifically treats illnesses attributed to the power of the place-based spirits called encantos. Encantos exist both in this world, and a parallel, "inner" world that is hidden from normal experience and perception. The power of the encantos is an invisible substance that has phenomenologically real effects on people. These effects are experienced first and foremost in and through the individual body, but they are also manifested in the social and material extensions of the person. Brujeria works in the spiritual world of the encantos, and the sorcerer's sombra or shadow enters this parallel world to learn how to extract the sickening power of the encantos from his client's body and restore their health and well-being.

People in Kañaris attribute responsibility for the outcome of the encanto's power through "distributive" and "intentional" agency. These are categories I have identified based on the implicit epistemological understandings of community members. The responsibility for witchcraft illness is shared by the encantos, the sorcerer, and his client. James Laidlaw's discussion of agency is significant because it articulates that responsibility for an outcome can be distributed among several agents. This is clearly the 
case in both the cursing and healing modalities of brujeria. The encantos are agential entities that participate in a chain of cause and effect within a particular set of relations that involve the sorcerer and his client (see Laidlaw 2010: 145-146). The encantos are functionally responsible for witchcraft illness, but people do not hold them morally accountable for the sickening effects of their power. People only assign moral responsibility to the human actors involved.

Encantos are agential entities who have the power to act and produce a predictable effect. While they are attributed with individualized names and identities, and express a self-generated will and intention towards the sorcerers with whom they have sacred relationships, they are not subjects in the human sense. Encantos do not normally interact with lay people directly; they do not "care" if particular people are ill or well. Nevertheless, they share responsibility for illness attributed to their power, since a person is afflicted with this type of illness by virtue of their power.

Community members do not, however, hold the encantos responsible for causing illness in a particular person at a particular time. The mediation of the sorcerer is necessary, for only he can direct the power of the encantos towards a person with the intention to harm or heal them. As we will see in the following chapter, sorcerers are morally suspicious, but they only cause illness when another person pays them to do witchcraft against a fellow community member whom they envy and want to harm. The socially real perpetrator of witchcraft is the envious client, and people hold this person morally responsible for this type of illness, misfortune, and suffering.

This is where the social impact of brujeria can be located. In this small and interrelated community, the local ideal is that people enjoy similar degrees of material 
and social well-being, and community members work together for the collective good. Yet resources and power are unequally distributed, and people can be selfish and evil, as well as generous and good. When one person envies the success and prosperity of another, the most extreme way in which they can harm their rival is through malicious sorcery, or witchcraft. The victim goes to a sorcerer to be healed of this illness and return to their normal state of being. In the process of diagnosis and healing, however, they also may learn which community member secretly perpetrated witchcraft against them to cause their suffering. A wise person does not attack the individual who has proven to be their enemy in turn. Rather, the conscientious person uses this knowledge to mitigate their vulnerability to future social and spiritual aggression. The person will continue to interact with their attacker within the parameters of social decency, but they will avoid them as much as possible. They will not place their trust in someone who has proven him or herself to be untrustworthy.

Brujeria is not just used by community members to intentionally harm a rival, however. In the following chapters, we explore the positive modes of brujeria in Kañaris in more detail, as a practice to increase one's luck and productive capacities, and to heal illness attributed to the power of the encantos but not witchcraft. We will compare and contrast the encantos of northern Peru with the mountain spirits of southern Peru and Bolivia. And we will see what actions and performative idioms are at work in the mesa healing ceremony. 


\section{Chapter 7: Sacred Geography}

"In the time before Christ there was a great rainstorm in Kañaris," said Andrés' father, don Leonardo. "It rained day and night until everything was filled with water. The people had no place to escape to, nowhere to go. Everything was flooded and people were dying, they were drowning. So they looked for the highest mountain they could find nearby. They climbed onto that mountain, onto the very peak of the mountain, to escape the water. Then the mountain began to grow. Grow, grow, grow. It raised the people high above the water. It saved them from death. It saved them from the flood."

I was sitting with don Leonardo on a bench against the back side of his house, looking at this very mountain. Don Leonardo was feeling better today, and he had invited me over to tell me about all the important mountains around Kañaris.

The mountain we were looking at is called Cerro Kutilla. Maestros ("masters," sorcerers) say that Cerro Kutilla isn't just made of earth. It is made of a heavy, solid "rock of steel." At night, bluish-black stones fall down the mountain, landing in the streams and grassy field at its base, which a main footpath crosses. The stones are small but heavy because of the iron ore they contain. These stones are the "offspring" of Cerro Kutilla. They have the power of the mountain or "cerro" in them. They are good to cure with, and so the best sorcerers look for these stones to use on their ritual tables. 
"The maestros call Cerro Kutilla during their mesas," don Leonardo told me. "They cure calling the cerros by name, shaking their rattles, and raising tobacco. This is their medicine. They cure at night when it is easier to call on the shadows of the cerros."

There is also one very powerful and special rock on Cerro Kutilla. Deep in the folds of the mountainside, surrounded by mossy trees and cool springs, sits "Qasay Rumi” (Cold Rock). This is a large boulder rising out of the earth that controls the rain. People's livelihoods depend on the rain. If the rains are late to arrive, people bring Qasay Rumi offerings of live guinea pigs, dried corn, and floral waters. They say that Qasay Rumi "eats" the offerings. If he is satisfied, the rains should come soon.

Andrés also told me about Qasay Rumi. Before, there were two such boulders in Kañaris. Some people say they were a husband and wife; others say they were a mother and her child. One brought the rainy season on, and the other stopped the rains for the dry season. The sacred boulders made Kañaris prosperous, with many cattle and sheep. But other people were jealous of their prosperity. So four evil sorcerers, brujos, took one of the boulders in the night. It left making a sound: "Wooooo." The brujos took the larger boulder to the neighbouring region of Cajamarca. Sometimes the sound it makes can still be heard in the night, calling to its spouse or child.

This wasn't the only thing brujos did out of envy. They also turned the face of a powerful mountain away from Kañaris, thus turning their luck as well. This is a mountain far to the south, called Cerro Zanawaka.

"It looks like a sleeping cow, and has horns made out of honeycomb," said don Leonardo. "It used to bring a lot of cattle to Kañaris. Others were envious of this. So the 
brujos turned the face of the cow. Then Cajamarca became prosperous, and Kañaris was left practically without luck."

Now it is Cajamarca that is famous for producing cattle, milk, cheese, and butter. Kañaris used to be prosperous, but envious people used brujeria to "turn" their luck. This was in the time of their great grandparents.

\section{The sacred geography of Kañaris}

The Kañarense landscape is animated by powerful spirits embodied in prominent mountains and other landforms. The most important mountain is Cerro Kutilla, which rises up behind the town. It is situated about three hours' hike north, deep in the forest. In the forested and sparsely inhabited mountains to the south is Cerro Zanawaka. Its peak resembles the head of a cow. The "face" of the cow is directed towards the district of Chota in Cajamarca, a region that is renowned for cattle rearing and its relative prosperity.

Cerro Zanawaka is at the "back" of Cerro Capitán. Within these mountains is the origin of the Kañariyaku River, which runs northerly to join the larger Huancabamba River. Many curative plants and wild animals such as speckled bears can be found there, along with the base of the mining operation, Cañariaco Norte. Community members say the "owner" of Cerro Capitán is a white woman who exits the mountain at night. Some say the mining engineers talk with Capitán to ensure the safe exploration and mining of the mountain. Many townspeople are incredulous of this and counter that it is only a story. Nevertheless, a lingering possibility of truth remains, since the spirit of Capitán 
resembles the director of the mining operation, who people know is a white woman with Candente Copper Corp.

To the west of Capitán there is another mountain called Cerro Yanaqaqa or Cerro Negro (Black Mountain). It is located close to Lake Tembladera in the uninhabited highaltitude southern zone of Kañaris, near the neighbouring district of Incahuasi. This is a curative lake where sorcerers bring their clients to make offerings and perform cleansing baths. There are also many medicinal plants found around this lake in "secret gardens." A person can enter these gardens only after being ritually cleansed and making certain offerings to "refresh" the lake and ask permission to collect the plants.

Another powerful high-altitude lake in the south is Lake Shin Shin. It is guarded by a seven-headed snake that protects the lake's immense richness. Sometimes sorcerers perform cleansing baths in the lake, and they call upon Lake Shin Shin and other powerful places in their curing songs.

Along the dirt road that leads to the paved highway across the Huancabamba River, there is a mountain called Cerro Campana (Bell Mountain). It makes a sound at night like a church bell. On the road by this mountain, there is a certain spot with two big rocks and a smaller one. The spirit of these rocks appears as a wildcat or puma at night, and one may die just by seeing this cat-spirit. It is called "Upaypiteq," which according to don Leonardo, means "spirit that cuts." Other mountains also have such evil spirits. For example, Cerro Ankash (Blue Mountain) to the north of the town has an enchanted, bluish-green cave. People say it has an evil spirit that comes out at night and prevents people from passing over its peaks. Even Cerro Kutilla has such a spirit. It looks like a person, and "grabs" nighttime travellers, making them sick. 
Another important place in Kañaris is El Chorro (The Waterfall). This is a prominent point where river water cascades over a high, sharp cliff. It is about a four hours' hike north of the town, overlooking the Huancabamba River in the valley below. People strongly associate El Chorro with brujería, and say that it has luck-enhancing and healing powers. Two well-known maestros live nearby the waterfall. At least one of them does cleansing baths for clients in the waterfall to increase their luck, particularly in raising cattle. People say the spirit of El Chorro is a white woman who lives in a hidden pool of water at its base. Early on in my fieldwork, men sometimes commented that I looked "just like" the woman of El Chorro. This comment made me uncomfortable because of the mix of fear and desire that it implies. However, I preferred this to being associated with the white female director of the prospective mining operation, who represents a different sort of threatening power, that of foreign extraction and domination.

The three stories that began this chapter describe the sacred mountains and placebased spirits of Kañaris. These are the encantos, and they can bring luck, production, and health. They also have the potential to effect loss and illness. In the previous chapter, we saw that sorcerers cure and cause certain classes of illness using the power of the encantos. Now we turn to examining the ritual performances of sorcerers in more detail. I begin by contrasting the encantos of northern Peru with their southern counterparts, the mountain spirits.

\section{Mountain spirits}

The mountains, lakes, and waterfalls that don Leonardo told me about are not simply prominent landmarks. As we saw in the previous chapter, they are individualized 
embodiments of sacred power, a power which does not have a form or substance in itself but which can be transferred through material objects and substances. These non-human entities are sometimes called cerros ("mountains"), and other times called encantos ("enchantments"). While the semiotic and practical fields that these terms refer to are distinct, they both connote a dual character of paramount place-based spirits as supernatural sources of well-being and suffering.

In the most general terms, cerros are tutelary powers that look after the people under their care. In this respect, they are part of the widespread Andean complex of "mountain spirits" described by scores of other ethnographers (see for example Allen 2002; Bastien 1978; Gelles 2000; Gose 1994; Isbell 1978; Sax 2011). Mountain spirits are powerful spiritual entities represented by prominent, named mountains. Throughout highland Peru, Bolivia, and Ecuador, Andean peasants find themselves interpolated by particular, typically local, mountain spirits. They attribute the mountain spirits with individualized identities, characteristics, preferences, and requirements. The mountain spirits expect and demand "offerings" and "payments" of corn beer, coca leaves, and other ritual consumables (see for example Allen 2002; Gose 1994; Fernández Juárez 1997). In return, they ensure the bounty of crops, the fertility of animals, the prosperity of households, and the health and well-being of individuals. Householders who neglect to make these offerings and payments experience crop failure, animal loss, and the illness or death of family members (see for example Bastien 1978: 154; Isbell 1978: 155).

In the southern Andes, people address mountain spirits with deferential Quechua terms such as apu ("lord"), mallku (“condor), and wamani ("hawk") (see for example Allen 2002: 26; Bastien 1978: 63; Gose 1994: 210, 2008: 296; Isbell 1978: 59). In 
Kañaris, however, people almost always referred to them as cerros. Moreover, unlike many other Andean communities, people in Kañaris are not bound to cerros through a "social contract" (Gose 2008: 280) in which they provide ritual offerings and payments in return for agricultural productivity and prosperity. Neither lay people nor households find themselves to be personally addressed by mountain spirits who demand ritual attention. Only sorcerers have individualized relationships with place-based spirits. Sorcerers are the only people who can establish contact with these spirits, and communicate with them so as to restore health and bring well-being.

\section{Production and care}

As don Leonardo's story of Cerro Kutilla and the flood illustrates, there are myths in Kañaris that represent mountain spirits as caring for people. However, based on the general practice surrounding mountain spirits in Kañaris, this is more an exception than the rule. In contrast, ritual offerings to mountain spirits are an integral aspect of agricultural production in the southern Andes. In southern Peru and Bolivia, both householders and ritual specialists make sacrificial offerings and "payments" to particular mountain spirits to ensure the fertility of crops and animals. However, lay people in Kañaris do not normally make offerings to place-based spirits. Nor do they consider ritual attention to these spiritual entities a necessary accompaniment to field preparation, sowing, harvest, or animal branding.

I observed only two instances in which people in Kañaris address place-based spirits to ensure agricultural success and prosperity. One involves the sacred boulder called Qasay Rumi. A couple of weeks after don Leonardo told me about the mountain 
spirits of Kañaris, I accompanied a group of community members to visit the boulder. That year, the seasonal rains were late. People were worried that if it did not rain soon, they would not get much from the corn, wheat, and other crops they had planted. As there is very little irrigation in Kañaris, subsistence agriculture is largely dependent on the rain. A group of people went to Qasay Rumi to beseech the spirit to bring the rains.

We hiked up Cerro Kutilla through the night to reach Qasay Rumi just before dawn. The man who led the journey was not a sorcerer. He was a well-respected older patriarch who often played a key role in community rituals, such as singing songs for the nighttime vigils of Catholic saints, and the mourning songs that accompany burials. A week before, he and his wife had presented Qasay Rumi with several live guinea pigs, which they had deposited in a deep crevice in the boulder and covered up with a large rock. Now that they returned, they found that the guinea pigs had disappeared. One participant told me that supposedly Qasay Rumi "eats" the guinea pigs, but in her opinion, the small animals had obviously escaped the crevice and fled into the mountains. Nevertheless, she had come to participate in the ritual to address Qasay Rumi in the hope of rain.

This time, the leader and his wife brought additional offerings for Qasay Rumi: "holy" water mixed with ground white corn, yonque (sugar cane alcohol), and commercially produced floral waters. The leader recited addressed Qasay Rumi and recited Catholic prayers. He sprinkled white corn water over the boulder, which is about the size of a car, half-submerged in the ground. Then he blew the floral waters all around the boulder in a fine spray from his mouth. One of the participants had brought a guitar, and he played it while everyone else danced around Qasay Rumi in a circle. The principle 
participants also drank yonque from a small shell, and sprinkled more yonqe on the ground for the spirit.

By this time, the sun was up. The leader and his wife said that since community members had neglected Qasay Rumi in recent years, the spirit was not bringing the rains for them. Several participants had brought hoes and machetes, and now everyone helped to clear the brush away from around the boulder. By clearing away the encroaching plants of the "wild" brush, they "domesticated" the site, reestablished it as a place of human activity, and renewed their relationship to Qasay Rumi. They hoped Qasay Rumi would care for them in turn.

The leader and his wife then shared the breakfast of boiled corn and potatoes they had brought for everyone. As the party made their way back to town, the men paused three times to drink yonqe. They stopped at established places, where they were "obligated" to drink with the mountain spirit. In former years, perhaps a generation ago, the entire community made a pilgrimage to Qasay Rumi whenever the seasonal rains were late or would not stop. From what participants told me, and what I observed, fewer and fewer people today believe this is necessary. Others said that the ritual "could" work, but that no one knows how to do it properly anymore.

The second instance in which I observed community members linking tutelary divinities and agricultural production occurred during the festival of the town's patron saint, San Juan de Bautista (Saint John the Baptist). This is currently the most important community ritual throughout the year. It is both a religious festival and secular holiday, combining public veneration and celebration of the saint with a market, music, and fireworks. The festival draws many people from the surrounding area, and is also an 
event that people living in cities return home for. San Juan de Bautista has his day on June 24, the main night of the festival. As he is the town's patron saint, community members expect in a general way that San Juan de Bautista looks after them. But San Juan also has a "little" counterpart who is celebrated on June 25. This second saint is also San Juan, but a different one: San Juan de Aguita (Saint John of the Little Water).

On the morning of June 25, about fifty people left the church at dawn with the clothed statue of San Juan de Aguita. The saint's female sponsor carried the statue and led the procession of mostly women to his chapel. This is located in a field below the town, beside a shallow pond. They were accompanied by a musician and two dancers who did the same "Bell Dance" that the men's dance group had done for San Juan Bautista in the church the night before. The musician was the same as the previous night. No one else is able to fill his role, which involves playing a flute and drum at the same time. The two dancers, however, were not members of the dance group. They were very drunk and did a comical parody of the highly esteemed dance.

The dancers had to be drunk, though, since they had a dangerous job to do. When the procession reached the chapel, there was a short vigil with prayers led by a visiting nun. Then one of the dancers carried the statue of San Juan de Aguita into the pond, and walked around the inner perimeter three times while the musician continued to play. People in Kañaris avoid direct contact such "undomesticated” water. Older people say that the spirit in the water will "grab" the person and cause illness. The dancer's drunkenness protected him from this possibility.

During the dancer's tour of the pond, San Juan de Aguita blessed "his" water. Afterwards, the nun said a short prayer and expressed her sentiment that participants 
should have faith in God, and not depart from Catholic doctrine by such quasi-idolatrous practices. For good measure, she consecrated the pond by sprinkling it with "true" holy water. The participants listened in polite silence. Then all the participants washed their hands, feet, and faces on the edge of the pond. They collected the water in empty sodapop bottles they had brought, and they gathered bunches of the tall grasses growing in the water. I had accompanied Andrés' wife, Isabel, and she told me that people would feed the grasses to their guinea pigs and use the water to bless their animals.

San Juan de Aguita is both a local saint and a place-based spirit connected to the well-being of animals. Since women are the primary owners and caregivers of household guinea pigs, chickens, sheep, and cows, I am not surprised that the majority of participants were women. By coming into bodily contact with the sacred water and grasses, the animals would receive the blessing of San Juan de Aguita, which would increase their health and fertility. Although this is an annual event, to the best of my knowledge the festival is the only time of year community members address San Juan de Aguita or any other saint in relation to their subsistence activities. The annual blessing of San Juan de Aguita, and the irregular visits to Qasay Rumi, are the only times I observed people addressing place-based spirits as tutelary divinities specifically to ensure the success of agricultural production.

\section{Dual capacity for generation and destruction}

In Kañaris, the guardianship and care of place-based spirits is not emphasized in local practice and discourse, as it is in many Andean communities to the south. Nevertheless, Kañarense place-based spirits share some key characteristics with southern 
mountain spirits. One of these is their dual capacity to bring life, fertility, and health on one hand, and death, loss, and illness on the other.

As tutelary divinities, mountain spirits are generally benevolent. It is their supernatural power that gives life and vitality to plants and animals (see Allen 2002: 3337; Gose 1994: 126-135). But they are also occasionally capricious and retributive (see Isbell 1978: 153-155). For example, a mountain spirit can punish householders who neglect them; travellers who trespass on their domain without proper ritual deference can become ill due to an angry mountain spirit; and miners should ask permission of the mountain spirit, or workers will die (see Crandon-Malamud 1991: 3-5; Isbell 1978: 153154; Salazar-Soler 2006: 163-169).

The generative and destructive modes of mountain spirits are clearly illustrated in relation to mining. Throughout the Andes, powerful spirits of mines are called tios ("uncles," which evokes the assistance and patronage of a rich business associate), or diablos ("devils," supay in Quechua, which refers to their potential danger, rather than opposition to all that is good) (see Salazar-Soler 2006). Miners must regularly provide the "uncle" or "devil" of the mine with offerings such as coca leaves and cigarettes, for he is hungry, and if he is not fed, he will take a human life instead (see Nash 1979: ch. 5-6; Platt 1983; Salazar-Soler 2006: 137-142ff).

Mountain spirits have the dual capacity to bring life and fertility, and loss and death. A person who suffers serious misfortune or illness attributed to a mountain spirit has either offended the supernatural entity and must make amends, or is being drawn into a more intense ritual relationship. For example, anthropologist Peter Gose relates the story of an Andean farmer he knew, whose calf was killed by a bolt of lightening (Gose 
1994: 220). When the man consulted an oracular medium, he was told that a mountain spirit named Phukawasi "had 'sold' the animal because the offerings he was receiving were inadequate" (Ibid.). Phukawasi demanded more elaborate ritual payments, and the man complied, which eventually resulted in an increase in his animals (Ibid.).

I did not hear any similar stories in Kañaris, but there householders do not have personal relationships with particular mountain spirits. However, mountain spirits occasionally address lay people, as illustrated by another story Andrés told me. There once was a man walking from his village to the city to look for work. The only person he meets on the road is a "gringo," a white man dressed in rich clothes and riding a horse. The powerful man offers the peasant a job on his nearby ranch. He says the peasant will be paid well, but he mustn't tell anyone about where the ranch is or whom he works for. The peasant agrees, and follows the landowner, who blindfolds him to hide the location of his land. The peasant doesn't know where he's going, but feels as if he's passing through a long, dark doorway.

When the landowner takes off the blindfold, the peasant sees a prosperous ranch inside of a mountain, with lush crops, green pasture, and plenty of sheep. The landowner tells the peasant that he's to take the sheep to pasture, and that he's to collect all the sheep droppings. The peasant does this, and when he brings the sheep droppings to the landowner, he finds they have turned into solid gold. This is the payment his boss gives him.

After a time working for this powerful landowner, the peasant says he wants to visit his wife and family. The boss allows him to leave, but warns him again not to tell anyone whom he has been working for. The peasant returns home, and everyone is 
amazed at what he's earned. "Where were you working?" they all ask. The peasant forgets his promise, and tells them that he's been working for the rich landowner.

A little while later, the peasant sets out to return to the ranch. But although he walks along the same road, he doesn't meet the landowner, and he can't find the ranch. The peasant can't even find another job. All his crops fail and he loses all his animals, and eventually he falls ill and dies himself.

The rich landowner in Andrés' story is the human incarnation of the mountain spirit. Throughout the Andes, people say that mountain spirits can take a human form and exit their mountains at night. Inside the mountain, they have incredible riches: prosperous fields and herds, hoards of gold and silver, or secret gardens with medicinal plants. A person who enters the domain of the mountain spirit may acquire wealth like he never could in the human world. But to do so poses a great danger. For just as the mountain spirit can give, it can also take away.

Dual identity as locals and foreigners

In his story, Andrés specifically characterized the human incarnation of the mountain spirit as a "white" foreigner. Throughout the Andes, the same mountains that are named as tutelary spirits are said to house powerful "owners" or "bosses," the spirit of the mountain in human form. Inside the mountain there is a world that mirrors the external world, just richer. The rich "owner" is said to exit the mountain at night, riding a horse, wearing boots and a wide-brimmed hat, with a pale complexion and bearded face (see for example Gose 2008: 297-298). In other words, he looks distinctly white or mestizo (of mixed descent), not like an indigenous peasant. The "owner" of the mountain 
is not a local, but a member of the ruling classes that long kept highland peoples in a subordinate position of indebted servitude.

This points to a second attribute that mountain spirits in Kañaris shares with those in the southern Andes: their dual identity as both guardians that belong to Andean communities, and as hierarchically superior foreigners and racial others. Mountain spirits are autochthonous to Andean communities because they are only recognized by and interact with community members. Mountain spirits do not "belong" to other people in Peru, and non-Andean peoples do not find themselves interpolated by these place-based spirits. As divine sources of life and fertility, mountain spirits provide for the people under "their" care. People recognize their reciprocal obligations to mountain spirits, and "feed" them in turn through ritual offerings and payments. In this "pact of reciprocity" (Gose 2008: 324), mountain spirits provide for Andean peasants, who in turn are obligated to provide for mountain spirits. In Kañaris, people do not normally address the mountain spirits for agricultural prosperity and success. Nevertheless, only community members acknowledge and encounter them.

Yet even as mountain spirits are community insiders, in their human form they resemble quintessential foreigners or outsiders. The human incarnation of a mountain spirit may be male or female, but it is always racially "white," at least in all the stories I have heard. The mountain spirit appears on horseback, and acts as if he were a large-scale foreign landowner, the kind of person who controlled much of the labour of Andean peasants during the nineteenth and early twentieth centuries through the haciendas. Many Andean peasants were obligated to work for such non-local landowners on large estates under highly exploitative, feudal-like conditions. Similarly, the "owner" or "boss" of the 
mountain is incredibly rich, with the prosperous fields and precious metals they house in their inner, hidden world within their domain.

The contemporary analyst may be tempted to account for the "white" human form of mountain spirits as Andean peoples' symbolic appropriation of the power of these racial, ethnic, and class-based Others. But this explanation is deeply unsatisfying. It slots Andean peoples into to Western categories and concerns, such as the politics of identity, which are not necessarily shared by Andean peoples, particularly in Peru. It also does not address basic ethnographic questions. If Andean peoples are supposedly concerned with racial or ethnic differentiation, why is it they do not reject white people altogether, and assert the superiority of their own divine representatives? And if Andean peoples are supposedly so concerned with preserving their "tradition" and "cultural uniqueness," why do rural, indigenous peasants develop people cosmopolitan tastes for urban music and the internet, and why are they interested in forging closer ties to white and mestizo people by asking them to be godparents to their children?

The wider theme of cultural politics will have to be set aside for the moment. To address the question of mountain spirits as both community insiders and outsiders, we will start by looking at the historical context in which these Andean place-based spirits have emerged.

\section{The historical roots of mountain spirits}

Why are mountain spirits described by Andean peoples as at once tutelary divinities and powerful outsiders? The answer is not as straightforward as critically reading race and class into the historical experience of Spanish colonialism and Christian 
evangelization would seem. Nor are mountain spirits simply a matter of cultural continuity with a primordial Andean past. To find an answer, we must look to the historical roots of mountain spirits, and also consider how their pre-Columbian and preChristian antecedents changed over time.

Anthropologist and ethnohistorian Peter Gose has done just this in his book, Invaders as Ancestors: On the Intercultural Making and Unmaking of Spanish Colonialism in the Andes (2008). I follow Gose in arguing that contemporary mountain spirits are a product of pre-Columbian forms of social, political, and spiritual orders on one hand, and the transformation of the lived Andean world through Spanish colonization and Christianization on the other. Prior to the arrival of the Spanish in the sixteenth century, the Incas and other Andean peoples venerated deified ancestors associated with particular places. In pre-Columbian myths - recorded by Spanish chroniclers (e.g. Betanzos, Cieza de León, Molina, Sarmiento de Gamboa) and the first descendants of the Incan nobility and Spanish elite (e.g. Pachacuti Yampqui, Guaman Poma) - communities were founded by ancestral beings who either rose up from deep within the earth or came down through lightening (Gose 2008: 18). The founding ancestors modified the landscape, domesticated uninhabited space, and expanded their territory by conquering other groups (Ibid.). After establishing the tribe-like community or "ancestorworshipping polity" of the ayllu, the ancestor turned to stone, and thereafter remained in the place where they had emerged or touched down (Ibid.). Andean communities venerated the stones of their founding ancestors and housed them in shrines (huacas) at these "dawning points" (pacarinas), located in a mountain or cave, or by a tree, spring, or lake (Gose 1993: 489ff, 2008: 18, 243). 
Furthermore, a community's local leader was represented as a direct descendant of the founding ancestor, and when he died, he was mummified and stored in the same shrine at the sacred place (Gose 2008: 16). The stones and mummies of the ancestors continued to be active participants in the well-being of their community. They were tutelary divinities who provided their people with agricultural fertility and prosperity (Gose 2008: 14-18). People regularly provided them with sacrifices and libations of corn beer (see for example Gose 1993: 486-487). As Gose contends, pre-Columbian Andean peoples venerated the ancestors housed in sacred places, not the places themselves (see especially Gose 2008: 165-166, 239-244).

The Spanish were deeply disturbed by this ancestor worship, which so closely resembled their own adoration of Catholic saints (see Gose 2008: 21). They established an office of the Catholic Church to root out and destroy this indigenous practice and belief. Under the Extirpation of Idolatries, the Spanish demolished Andean peoples' sacred stones and shrines, burned their mummies, and erected crosses in their place (see Gose 2008: 156-160, 274, ch. 7 passim). Meanwhile, local elites and commoners each forwarded their own interests in the changed political-economic context. Some converted to Christianity and married Spaniards; some became colonial administrators; and others abandoned their natal communities to avoid burdensome labour tribute (see Gose 2008: 136-137). By the end of the eighteenth century, a new ritual order had emerged in the Andes. Instead of the ancestors animating the land, now the landscape itself was personified (Gose 2008: 241). Andean peoples came to recognize particular mountains as their tutelary divinities and local powers who mediated relations between the community and the state (see Gose 2008: 11-12, 296-297). 
Yet there is a further twist to this story. People in the Andes today do not simply consider mountain spirits to animate and vitalize the land. They also say that the human incarnation of the spirit looks like a white foreigner or powerful overseer. Gose's ethnohistorical work is again enlightening. He argues that the idea of local divinities as rulers as foreign to "their" people made sense in the pre-Columbian Andes. Empire and colonization were "fully developed" before the Spanish arrived, and the region had already undergone several waves of political "expansion, contraction, and subsumption" (Gose 2008: 17, 20). The Incan empire was only the most recent iteration of this indigenous form of intrusive conquest and foreign rule. The foreignness of local, divine rulers is also marked in Incan myths, in which founding ancestors "conquered and partially displaced previous groups and their ancestors" (Gose 2008: 18). Newly conquered peoples were not exterminated or dispossessed, but instead obligated to share their "agricultural resources and women with the conquerors" (Gose 2008: 19). That is, they had to provide tribute in the form of material and social resources that made the administration of the Incan empire possible (see Gose 2000).

The "political script" following Andean conquest was for the two groups to coexist more or less peacefully, with "significant intergroup reciprocity and symmetry" (Gose 2008: 19, 20). For example, ruling and subjugated groups recognized they shared a common ancestor, or worshipped each other's ancestors (Gose 2008: 17). In each successive wave of conquest, the founding ancestors of the vanquished group continued to exist, only now in a relation of shared kinship to those of the hierarchically superior group. This mutual recognition of ancestral relation ritually legitimated their alliance and peaceful coexistence (Ibid.). Conquered peoples retained a degree of local sovereignty, 
including the right to venerate the ancestor who had founded their local polity, who was represented by their local lord (curaca) (Gose 2008: 15-17). Gose argues that the preexisting Andean order conventionalized the idea of intrusive conquest, and presumed that the ancestors had distant origins, distinct from the communities they founded (1993: 489ff, 2008: 20, 299).

These pre-understandings played a critical role in how Andean peoples received the Spanish, first as potential usurpers of the Incan empire, and then as colonial rulers. Colonizers were people with whom subjugated groups expected to share common ancestors, and therefore common interests and reciprocal obligations (see Gose 2008: 1421, 64-66). For the first century, local lords played an important role in the "indirect rule" of the Spanish colony of Peru (see Gose 2008: 43-47, 81, 128-136). Archival documents indicate that throughout the sixteenth and seventeenth centuries, both local elites and Andean commoners continued to recognize and venerate their founding ancestors and ancestral mummies, albeit in constant negotiation with Spanish colonial administrators and representatives of the Catholic Church (see for example Gose 2008: 155-160). By the late eighteenth century, however, the Spanish had stripped the lords of their power and privileges, and many had abandoned their offices (Gose 2008: 237-239, 277-279). At the same time, Andean commoners came to reject their local lords and ancestral rulers, whom they no longer considered their political representative and sacred sources of fertility (Ibid.). People came to regard the sacred stones and mummies as the remains of threatening pre-Christians and pagans, unrelated to them (see Gose 2008: 283-294). Today, many Andean peoples consider pre-Columbian burial sites and arefacts to be the remains of these malicious spirits, called gentiles. 
Yet ancestor worship persisted in another form. According to Gose, after the collapse of the indirect rule of local lords, "localized divine kingship" became "progressively more subaltern," defined by indigenous commoners who made the mountain spirits into their new tutelary divinities (Gose 2008: 322-324). Mountain spirits took on the roles of provision and mediation with higher levels of political administration, which the local lords and founding ancestors had fulfilled in preColumbian times. For example, lords gathered tribute on behalf of the Inca, and redistributed products and resources to commoners (see Gose 2000; Murra 2002: 47ff; Rostworowski 1999: ch. 6). This continued through the indirect rule of local lords in the Spanish colony up to the eighteenth century (see for example Gose 2008: 130-134). But as local lords "systematically broke" the implicit Andean social duty for elites to protect the community and ensure prosperity, "commoners stopped sacralizing them through ancestor worship and transferred their authority to mountain spirits, who personified the new community-based republicanism" (Gose 2008: 279). Instead of the founding ancestors, Incas, or local lords, Andean peoples now owe mountain spirits "their fundamental social allegiance," organized through "residence and affinity" rather than descent-based ayllu groups (Gose 2008: 241). Commoners came to demand "protection and prosperity from such spirits and the republican states they came to represent" (Gose 2008: 280).

Gose suggests the emergence of place-based spirits was partly out of a culturally grounded habitus, that is, the long-standing Andean practice of making sacrificial offerings in sacred places to "ancestor-rulers" who animated the local landscape (Gose 2008: 322). More significantly, however, Andean commoners also took up an innovative 
"egalitarian levelling" of the "previous ancestral regime," in which local mountain spirits took on the "[p]olitico-ritual mediation" previously carried out by local lords and ancestral deities (Gose 2008: 322, 323). Gose argues that this "conscious reform and reconstruction" of "the ancestral past" was deployed by Andean commoners partly as a strategy to demand that colonial (and post-colonial) administrators continue to provide them with the means to support themselves (2008: $324 f f)$.

Following Gose, the whiteness and foreignness of mountain spirits is - or arguably was, at least until the rise of identity politics in the late twentieth century about Andean commoners holding the state accountable, rather than symbolically appropriating the racial, ethnic, and class positions of people who held power over them:

... Andean people repeatedly extended their ancestral relation with mountain spirits into political struggles over the land, using them to articulate successful alliances with the state and regain land lost to hacendados... In these and more routine agrarian contexts, Andean people clearly relate to mountain spirits as ancestral advocates, and do not worship white domination through them. (Gose 2008: 298)

Through the mountain spirits, Andean peoples came to assert a shared genealogy with ruling elites, a longstanding "Andean" notion that draws elites and commoners into a relationship of reciprocal obligations. From this perspective, the state is morally obligated to provide Andean peasants with the means to support themselves and achieve their own goals, such as agricultural livelihoods and meaningful political participation.

Place-based spirits in the Andes thus developed out of two processes. The first is the pre-Columbian practice of ancestor worship and divine kingship, in which Incan and other Andean peoples interred the sacred stones and mummies of their ancestors in 
mountains and other prominent landforms. The second is the constraints Andean peoples faced and the strategic responses they employed in the context of Spanish colonialism and Christian evangelization. In the centuries following the arrival of the Spanish and the demise of the Incan empire, Andean peoples moved away from their customary leaders and forms of worship. Eventually they came to understand the mountains themselves as embodiments of supernatural entities, who are repositories for a vitalizing energy that makes their crops and animals fertile.

Contemporary mountain spirits are at once tutelary divinities and foreign to the localities and polities they represent. This was also the function of their pre-Columbian antecedents. Mountain spirits are white outsiders not because these powerful foreigners are inherently threatening, or because the ruling elites have long had a control over wealth. The mountain spirits have to be white, because this symbolically articulates a kinship relation between the community and their political superiors (who are now representatives of the republican state instead of an invasive conquering group). Contemporary Andean peoples want to be "related" to these outside rulers, not because they wish to share the same racial or ethnic identity, but because this makes the state morally obligated to recognize their legitimate participation in the nation as citizens, modern on their own terms.

Synthesis

Throughout the Andean cultural area, mountain spirits are place-based spirits embodied in particular, named mountains. They are repositories for a life-giving and vitalizing energy, and Andean peasants (particularly in the southern Andes) address them 
to ensure the fertility of their crops and herds. The power of mountain spirits has the potential to bring both life and prosperity, and misfortune and death. In their benevolent form, mountain spirits are tutelary divinities who provide for the people under their care. But they can also be capricious and threatening, "eating" the crops and herds, or “grabbing" a person, to demand more sacrificial payments.

The dualistic character of mountain spirits is further illustrated by the human form Andean peoples say they take: a rich, white person, whose dress and comportment immediately marks him or her as not native to the community. Yet Andean peoples recognize they belong to the mountain spirits, and the spirits belong to them. Mountain spirits are sacred sources of fertility and prosperity, and Andean peoples should address them with deference and respect. They animate the local landscape and appear as powerful foreigners, because these were also key characteristics of localized divine rulers in the pre-Columbian Andes.

In Kañaris, the tutelary functions of mountain spirits are not foregrounded as they are in Andean communities to the south. There are very few occasions in which community members directly address mountain spirits to ensure the success and prosperity of their agricultural production. Nevertheless, people do recognize numerous mountain spirits, each with its own name and individual characteristics. For example, Cerro Kutilla and Qasay Rumi are associated with the seasonal rains, and Cerro Capitán guards precious metals.

In the context of brujeria, however, community members group mountain spirits together with other place-based spirits embodied in high-altitude lakes and waterfalls. These are the encantos that a sorcerer calls upon to enable him to cure (or cause) illness 
attributed to their supernatural power. In Kañaris, lay people do not have reciprocal relationships of feeding and sacrifice with mountain spirits. Instead, the sorcerer mediates the interactions between people and encantos by directing their spiritual power towards particular individuals.

\section{Encantos}

Encantos are place-based spirits embodied in particular mountains, high-altitude lakes, and waterfalls. Like mountain spirits, they are repositories for a sacred power that has the potential to bring both prosperity, health, and well-being, and illness, loss, and misfortune. However, unlike mountain spirits, this power is not circulated between lay people and spiritual entities through ritual offerings and payments. Instead, sorcerers are the only people qualified to direct this power towards people. By virtue of his innate ability, learned technique, and sacred pacts, the sorcerer calls upon "his" encantos to cause and cure illness, and to "raise" a client's luck or contaminate them with "bad luck." He does this during a ritual event called the mesa.

Encantos are specific to northern Peru. Sorcerers in both the highlands and the coast communicate with these place-based spirits to empower their ritual tables (also called mesas). As I outlined in the Introduction, the performance of brujería (sorcery) throughout northern Peru is the same, but the motivations of clients and the understanding of the sorcerer's efficacy are significantly different for people in the highlands and on the coast. As we saw in the previous chapter, brujería in the highlands of Lambayeque and Piura works with the sombras (shadows) of people and encantos. 
People in Kañaris usually responded to my questions about brujeria by indicating that sorcerers cure certain classes of illness that cannot be treated by other medical traditions. We will examine a healing mesa in more detail in the following chapter. In this section, I outline the full extent of what sorcerers do in Kañaris, at least as far as I was able to find out.

\section{Production and luck}

As I have argued, lay people in Kañaris address place-based spirits to increase agricultural production on only two occasions: during the festival of the town's patron saint (when San Juan de Aguita blesses farm animals), and during times of exceptional need for rain (when Qasay Rumi brings on the rainy season). In my understanding, community members do not generally look to place-based spirits to provide agricultural fertility and prosperity, as I found to be the case in the southern highlands (see Sax 2011). Nevertheless, regular people can consult a sorcerer to use the power of the encantos to increase their productive capacities and "luck."

As we saw in Chapter 5, "luck" is a concept community members use to account for the unpredictable and uncontrollable distribution of success and suffering. In summary, luck (1) comes from outside the person; (2) occurs independently of human action or inaction; (3) is possessed or experienced by an individual for an unpredictable length of time; (4) is unequally distributed among community members; and (5) is in limited supply, such that when one person has "good luck" another must have "bad luck." In this sense, luck is a "limited good" in George Foster's (1965) sense, even if in Kañaris 
it does not function as mechanistically alongside envy as he proposes desirable forms of property and value do in peasant societies in general.

In my reading of the local understanding, luck is a significant aspect of production and general well-being in Kañaris. People understand production to be the outcome of an individual's work and effort. But it is also dependent on factors beyond an individual's control, such as weather conditions, and the material and social resources that make subsistence agriculture possible. In my observation, community members indicate that a person whose efforts are unproductive and unsuccessful despite their diligent labour has "bad luck."

Moreover, an individual's state of luck is not a consequence of what they have done or failed to do. For example, people cannot make sacrificial offerings to place-based spirits to ensure their agricultural success, as householders can in the southern Andes. In Kañaris, success and suffering are not a direct outcome of their social and moral relationships with mountain spirits or another divine entity. But nor are people personally responsible for all their circumstances. The outcomes of a person's actions are affected by their "luck," which describes both the individual's qualitative evaluation of their subjective experience of their circumstance, and an impersonal force external to the individual.

Ultimately, luck either originates in or is mediated through the encantos. Their power has the potential to produce both helpful and harmful effects in the body-subject and total situation of the individual person. In its helpful mode, their power blesses them with "good luck." In its harmful mode, this same power is mal (evil), and curses a person with "bad luck." A sorcerer can direct the power of the encantos towards a particular 
person with the intention to either help or harm them. But in my observation, community members usually experience their state of luck as separate from their vulnerability and exposure to witchcraft and the encantos. Thus it seems that in Kañaris, a person's current state of luck occurs independently of both their actions, and the actions of social others.

When an individual's luck changes from bad to good, it does not necessarily mean that this was brought about through a mesa. Yet although "bad luck" is not always the result of witchcraft, if a person wants to "cleanse" and "raise" their luck, they will visit a sorcerer to do this by calling on the encantos. This will in turn change the successful possibilities of a client's productive activities and mitigate their vulnerability to future suffering.

\section{Mesas to increase production}

In Kañaris, there are two types of mesas that specifically concern production. In one, the sorcerer prepares an "herbal remedy" called a "mallqey." This herbal mixture is distinct from those prepared by other traditional healers. It does not cure illness. Instead, it permanently modifies the person's subjective experience and bodily capacities.

According to Andrés, when the sorcerer gives the client the special herbal mixture, the "spirit" of the plants is transferred to them. For example, "bull mallqey" makes a man become like a bull, transforming him into a good, strong worker, resistant to rain and cold when working in his fields. "Condor mallqey" is to overcome laziness, to increase a man's ability to work, and to make him able to withstand high altitudes without becoming sick or disoriented, like a condor. "Puma mallqey" makes a man like a wildcat or puma, quick and agile in whatever he is doing, such as dancing. Andrés told 
me that his father had taken one or more of these mallqeys when he was younger. The mallqeys made don Leonardo strong and resistant, and this is why he had been able to "withstand" his cancer for so long.

The one herbal remedy that sorcerers prepare specifically for women is called "shukshu mallqey." It increases a woman's ability to work, and above all, to spin wool using a hand spindle, or "shukshu." Isabel's neighbour, who was her aunt, told me that she had taken shukshu mallqey when she was younger. She was about sixty years old, and like numerous women her age, she was a skilled weaver. I spent many hours watching her weave in her backyard on sunny afternoons.

A mesa to modify and enhance a person's productive capacities takes two nights. On the first night, the sorcerer gives the client another herbal remedy (called an "hornamo") to do an "internal cleansing." The sorcerer gives the client the mallqey on the second night. He crushes the plants with stones from his ritual table, mixes these with water, strains it, and gives the liquid to the client. Some of the plants can also be chewed directly. When the client takes the mallqey, the sorcerer presides over his ritual table and continues to work with his power-objects to address the encantos.

He also monitors and "refreshes" the client with floral waters so they are not overcome by the power of the mallqey. For example, bull mallqey can make the client scrape the ground with his feet and tilt his head like an angry bull ready to charge. Condor mallqey can cause a man to flap his arms like the wings of a bird. Puma mallqey is the most dangerous of all, because the client can start acting like a wildcat, attacking household animals and eating them raw before running into the mountains. I suspect that the ingredients used in mallqeys include psychotropic plants such as Brugmansia 
suaveolens, Datura arborea, and related species. These plants are called "floripondios" in Kañaris; in other areas of northern Peru they are also called "mishas" (see Camino 1992: 187-197; Polia 1996: 333-344; Sharon 1978: 40).

In the second type of mesa for production, the sorcerer uses iconic figurines called "iyas" to "raise," "bring," or "grab hold of" a client's luck in a particular sphere. For example, figurines of corn cobs increase corn yields, figurines of animals increase herds of sheep and cattle, and antique coins increase business. It is important that the sorcerer "names" the specific request when doing this kind of mesa. That is, the client cannot request to increase his "luck" in general, but must request it specifically in regards to his fields, his animals, or his business.

According to Andrés, these iconic objects are described as "iyas" because they have the same sombra or "shadow" as the encanto. We will return to these and other power-objects in the following chapter. For now, the important thing to know is that mesas to increase luck in productive activities direct the power of the encantos towards a person with the intention of helping them.

\section{Illness and healing}

Community members evaluate their experiential state of luck in terms of their productive activities, as well as the condition of their social relationships, which make production possible. They also closely associate luck with the individual body-subject. Luck is experienced and demonstrated in both the material body of the individual and the total, embodied person in his or her social, political, and economic setting. Thus "bad luck" is one of the indications of illness, particularly if this illness is due to witchcraft. 
Symptoms of witchcraft illness include persistent bodily malaise that does not respond to other forms of treatment, crop and animal loss, business failure, prolonged social conflict, and the inability to achieve one's goals.

People in Kañaris always say that witchcraft is perpetrated by one community member who envies another. The envious person visits an unscrupulous maestro (a brujo) so as to purposefully harm their rival. The brujo calls upon the power of the encantos to curse the victim, causing them misfortune, loss, and death in their productive activities and household. The victim will have to visit another sorcerer to heal them of this illness by calling on the same encantos.

A person can also contract an illness attributed to the power of the encantos through accidental contamination or trespassing on an encanto's domain, but this is more rare than witchcraft. Whatever the root of the illness, if it has been caused by the power of the encantos, only a sorcerer can cure it, since only he can communicate with these place-based spirits. Logically, there would be no need for healing sorcerers if there were not unscrupulous practitioners (brujos) who did witchcraft in the first place.

Mesas to do witchcraft

In Kañaris, to do witchcraft is to "brujear." As we have seen, sorcery or "brujeria" is the term locals use for the two-sided practice that encompasses both causing and curing illness with the power of the encantos. Locals reserve the term "brujear" to describe a mesa or the actions of a sorcerer who is working to effect illness through malicious ritual actions. This is witchcraft. A sorcerer who is currently doing witchcraft is "brujeando," and a mesa set up to do witchcraft is also one that is "brujeando." A 
sorcerer who does witchcraft is evil, and then he can be described as a "brujo" or "malero."

Andrés named and described several types of witchcraft illness for me. One is when a person has "one problem on top of another." To treat this, a sorcerer bathes the client in the water of the encanto called El Chorro early in the morning. A similar condition is when a person is beset with severe bad luck, loss of work, or business failure. Sometimes open wounds that do not heal are also due to witchcraft, and a sorcerer makes a special herbal remedy for it. According to Andrés, the wound is "eaten" by the animal spirit in the remedy. Another witchcraft illness is indicated by ill-being in one's house, such as prolonged conflict or fighting with family members or neighbours. And yet another makes the victim forget the conflict he has with the perpetrator. For example, in the case of a land dispute, the victim will forget what he wants to achieve, and so his rival can win the case. All of these conditions need a healing mesa in order to be resolved.

Witchcraft illnesses are "hits" from other sorcerers. They come with a sudden, acute, and phenomenologically distinct pain. The pain is located in specific regions of the body, for example the head (which will need a "sucking"), or stomach (which can be treated with purgative plants such as San Pedro).

To do malicious witchcraft, a brujo directs the power of the encantos towards specific person so as to cause illness, death, crop and animal loss, business failure, and serious misfortune. A brujo does this on behalf of a client who pays him to hurt a fellow community member. From what Andrés told me, a mesa to do witchcraft is similar to one to cure illness. Some of the power-objects may be different, but the brujo still sets them up on a ritual table to address the encantos with whom he has secret "pacts." This is a 
black, left-handed, or "echoq" table with the bones of the "gentiles." These are human bones and burial remains that locals say come from an immoral, pre-Christian people. They bring only sickness and death, never prosperity and life. The brujo uses the bones to direct the power of the gentiles so as to cause a victim illness and misfortune. According to Polia (1996: 123, 162), the gentiles are a class of encantos: powerful spiritual entities associated with particular places and embodied in particular objects. That a ritual specialist can work with the bones of gentiles indicates that he can harness their power to affect people according to his will and intention.

The most important difference between mesas to cause and cure illness is the intention of the ritual specialist (see also Polia 1996: 120). In a mesa to do witchcraft, the brujo directs the power of the encantos to curse and harm a victim. He directs their power into a bundle that includes an object closely associated with the intended victim — for example, a lock of hair, piece of clothing, or photograph. The client then takes this sorcery bundle and secretly hides it in the house or business of the person they wish to harm. When the victim comes into physical contact or proximity with the witchcraft bundle, the power of the encantos in its sickening form enters his or her body. The victim is then cursed and contaminated, and can only be cleansed and healed by a sorcerer. As long as the encanto's power remains in the victim's body, he or she will experience an illness that does not respond to any other type of medicine. As we saw in the previous chapter, this is because the immaterial power of the encanto is acting on an immaterial part of the person: their sombra or "shadow." If left untreated, the victim can die.

Another type of witchcraft table is called "jullo," or "cursed." Cursed tables make the victim "lose his desires" and unable to complete his or her goals. When a healing 
sorcerer "closes" a curse and "fights" against the evil witchcraft, he puts on the clothing of a woman. In "jullo," the sickening spiritual power is associated with a malicious supernatural figure that takes a female form. Why female? There are two other instances in local myth where evilness takes a specifically female form. One is a cannibalistic ogre called the "Aĉkay," who is featured in several gruesome Kañarense fairytales (see also Taylor 2008). Another is the cursed or "jullo" spirit-woman. Andrés told me that when one encounters a lone woman on the road at night, it is actually an evil spirit called a "jullo." It must be an evil spirit, because it is unthinkable that a real woman would be walking outside of the town alone at night. This spirit-woman is "cursing," and brings bad luck to one's trip. A traveller who encounters this spirit "might as well go back home," because he will not be able to achieve the goal of his journey.

In a general sense, Andean cosmology emphasizes pairs of dialectical opposites (e.g. male/female, upper/lower). In this case, the "evil" female figure is not counterpoised to a "good" male force, but the normative goodness of a real woman. Women are not associated with the evilness or threat of this supernatural figure. The real woman ideally brings life and cares for others, while the "jullo" spirit-woman only effects misfortune, illness, and death. The sorcerer has to put on a woman's clothing to cure the curse that results from an encounter with this spirit because, in brujeria, the same spiritual power that caused an illness must be used to overcome it.

\section{Mesas to cure illness}

In a healing mesa, a sorcerer calls upon the same encanto that caused the illness in the first place. Each encanto is connected to a specific power-object, which are primarily 
the sorcerer's sacred rocks, staffs, and swords. According to Andrés, they are called "koteqa" because they contain the same immaterial substance that is the power of a specific encanto. The sorcerer uses them to "extract" this sickening substance from the client's body, as well as "block" or "fight" against the encanto that is causing a client's illness.

A sorcerer can also heal illness with another type of power-object, called the "iya." As we saw above, these are objects or figurines that physically resemble the thing they are connected to. For example, a figurine of a corn cob is connected to corn. This iya is used to cure a condition called "surrounding corn," which causes spots or bumps on the face that resemble corn kernels. Since corn is not among the handful of plants that community members say have a "spirit," I suspect that the corn cob figurine is ultimately connected to a an encanto that is responsible for the generative force in the corn plant.

Like the koteqa, the iya is spiritually connected to a specific encanto. However, the ontological relationships of these two classes of power-objects to their spiritual sources differ. While the koteqa contains the spiritual force or "power" of an encanto, the iya contains its sombra ("shadow"). The rocks, swords, staffs, and iconic figurines on the sorcerer's ritual table function as mediating conduits to specific encantos. A specific power-object must therefore be used to cure an illness that has been caused by the power of that same encanto. The sorcerer learns which encanto is responsible when his sombra communicates with the sombras of these non-human entities in the parallel spiritual world.

During a healing mesa, the sorcerer employs a rhetoric of curing and cleansing through the extraction of the invisible substance that is the power of the encantos. He 
"refreshes" the sacred power-objects on his ritual table by blowing floral waters in a fine spray through his pursed lips. He shakes a rattle and sings secret songs to "wake up" the presence of the encantos latent in his power-objects. He then "rubs" one or more of these objects over the client's body to "extract" the invisible illness-causing substance, or mal, that is the power of the encantos in its sickening form. Through this physical contact, the spiritual substance transfers from the client's body to the power-object, and the sorcerer can then "dispatch" or send it back to the mountain or high-altitude lake from where it originated. He may also place his lips on the region of the client's body where the sickening power of the encanto has become lodged - for example, the crown of the head, nape of the neck, upper chest, stomach, hands, or feet - to "suck out" any of the invisible substance that remains. To strengthen the client during this process, the sorcerer "raises" tobacco, nasally ingesting a mixture of sugar cane alcohol and tobacco leaves.

Throughout the night, the sorcerer continues to sing to the encantos with whom he has ritual pacts, and "refresh" the power-objects on his ritual table, making personal offering to the place-based spirits. He also travels to the parallel world of the encantos to speak directly with them. He drinks a cooked mixture of the mescaline-rich cactus San Pedro to detach his sombra from his body and enter the spirit world to "vision" and learn what he must do to treat his client's specific condition. The sorcerer may also direct his client to "raise" tobacco, drink San Pedro, or "refresh" the ritual table throughout the night. At the end of the ritual session, the sorcerer and his client undertake a final blessing and "flowering," nasally ingesting "sweet" floral waters, and blowing more over the ritual table. The entire event of the mesa diagnoses the client's condition, extracts the illness-causing substance from the client's body, sends this power back to the encantos, 
and cleanses and blesses the client to restore his or her health, productivity, good luck, and general well-being.

While I have highlighted sorcery illness as the outcome of malicious witchcraft, not all the illnesses attributed to the power of encantos are due to intentional ritual actions. The encantos can also cause illness through accidental contamination and direct contact. For example, if a maestro does not ritually cleanse his power-objects after using them in a healing mesa, any person who touches them will become contaminated with the spiritual power that is dormant in them. For this reason, a sorcerer "closes" the mesa by blowing sugar cane alcohol and floral waters over his power-objects, and then wraps them in cloths and stores them in a hidden spot. Bodily contamination can also occur during the "dispatching." When a sorcerer takes the rocks, swords, or staffs outside after "rubbing" them over the client's body, he sends the sickening power back to the encantos. If the sorcerer is not careful to direct the invisible substance through uninhabited fields, anyone who is in its line of travel will become sick with the power of the encantos. In both these forms of accidental contamination, the illness must be cured with a healing mesa.

Occasionally, a person will become ill by coming into direct contact with an encanto. For example, if a person walks by a mountain or lake at night, the encanto embodied in the landform may "frighten" or "grab" the person's sombra, as we saw in the previous chapter. Adults can also fall ill when they enter the "secret gardens" of the encanto. For example, a person will go to the forested mountains to harvest special plants to make an herbal remedy. These plants "belong" to the encanto around which they grow. 
If the person does not offer the encanto sugar cane alcohol and floral waters in compensation for harvesting its plants, the encanto will cause the person to fall ill.

Encantos can also address the sorcerer directly, since he shares an individual relationship with them through his ritual "pacts." If he neglects his obligations to the encantos, they will become angry and punish him with illness. For this reason, the sorcerer has to continuously "refresh" the encantos with sugar cane alcohol and floral waters during the mesa ceremony, to compensate them for allowing him to work with their power. I suspect that sorcerers also have to visit specific encantos on occasion to present them with more elaborate offerings (see for example Polia 1996: 98, 113-114).

\section{Chapter conclusion}

Mountain spirits and encantos are powerful non-human entities embodied in specific places. Andean peoples name these sacred places, and attribute them with individual identities and characteristics. In the highlands of southern Peru and Bolivia, mountain spirits play an essential role in agricultural production. In the south, human and supernatural relations are mediated by the idioms of sacrifice, payment, hunger, and feeding (see Allen 2002: 129-130; Crandon-Malamud 1991: 124; Fernández Juárez 2004: 135; Gose 1994: 222-224; Sax 2011: 83-84, 89-92). In this sense, ritual offerings and sacrificial payments in the southern Andes mediate the undomesticated power of the mountain spirits, and direct it towards people's desired goals.

Southern mountain spirits have an animating and vitalizing power that makes plants grow and herd animals multiply. Andean peoples expect their mountain spirits to provide agricultural productivity and fertility. They also find themselves to be personally 
interpolated by these place-based spirits, who demand offerings and payments such as corn beer and coca leaves in return. If a householder neglects to make ritual offerings, the mountain spirit will make them ill. This is the physical manifestation of a demand the mountain spirit is making of the person. For example, the person has neglected the mountain spirit, who has grown hungry, angry, and retributive. Or the mountain spirit may want to draw the householder into a more involved or serious ritual relationship. In the southern Andes, illness attributed to mountain spirits is in part about lay people's personal relationships to tutelary divinities that animate the local landscape.

The encantos of northern Peru do not carry out the same functions as southern mountain spirits. While encantos are also repositories for a sacred power, people do not direct this power to make their crops grow and animals fertile. Instead, the power of the encantos is integral to curing certain classes of illness, "raising" a person's luck, and perpetrating malicious witchcraft. In the northern Peruvian Andes, only sorcerer can communicate with the encantos. In this sense, sorcerers mediate the relations between people and place-based spirits. While encantos can cause illness through accidental contamination or direct contact with a person, usually their power causes illness through ritual actions intended to harm. In witchcraft, an evil sorcerer directs an encanto's power towards a specific person with the intention of harming, instead of healing. Sorcerers are not motivated to do this themselves. They only do witchcraft on behalf of a paying client, who is a fellow community member who envies and wishes to harm the victim. Sorcerers therefore also mediate relations between fellow community members.

For the sake of clarity, I have made a clear distinction between mountain spirits (cerros) and encantos in Kañaris. In practice, however, the important distinction is what 
functions the place-based spirit is fulfilling in relation to people in a specific situation. In their occasional roles as tutelary divinities, cerros resemble the mountain spirits of the southern Andes. But when a sorcerer invokes them during a mesa ceremony, these placebased spirits are clearly "encantos," which are specific to the practice of brujeria in northern Peru. Sorcerers call upon the encantos by their same mountain names: Cerro Kutilla, Cerro Capitán, Cerro Zanawaka, Cerro Yanaqaqa, Cerro Campana, Cerro Ankash. Encantos are also embodied in prominent bodies of water, such as Lake Tembladera, Lake Shin Shin, and the waterfall El Chorro. All of these spiritual entities and sacred places are repositories for the supernatural power that the sorcerer directs so as to cure (or cause) illness, increase good luck, and cleanse bad luck.

The most important difference between mesas to cause and cure illness is the intention of the sorcerer. The encantos do not "care" if an individual experiences ill-being or well-being. Their power has the potential to bring both health and illness, but these effects are not usually the result of the encanto's intention towards the person. Instead, their power is harmful or helpful according to how it has been directed by the intention of the sorcerer, and the client on whose behalf he acts. The encantos thus exist in a dynamic relationship that includes more than one human actor.

In Kañaris, illness attributed to the encantos matters not because of people's relations to localized divinities, but because of the social and political motivations of another person that have set it in motion, and the material and social consequences that result from it. What is really at stake in human and relations with place-based spirits is that people can use the power of non-human entities to produce destructive or generative 
outcomes. Encantos matter because the ways in which their power is used tells people something about their relations with fellow community members. 


\section{Chapter 8: The Mesa}

"We're having a healing ritual for my father tonight," Andrés told me. "The maestro has already arrived to work on my father, who is a little delicate."

We were talking in hushed tones behind the closed door of his storage room, where neighbours were unlikely to overhear our conversation. I had been living in Andrés and Isabel's house for two months. Andrés' father, don Leonardo, was very sick. Despite an operation to remove a tumour on his neck, his cancer had returned. Don Leonardo's family was arranging a healing mesa for him. They had contracted a ritual specialist called a "maestro" (master) to perform the highly secret ritual in don Leonardo's house.

Andrés explained that the day before, he and his brother had left at dawn to walk through the mountains to the maestro's homestead, located in another village about four hours away. The maestro had arrived at don Leonardo's house shortly before suppertime, with his assistant and two horses loaded with heavy bundles of power-objects that he would use in the healing ritual.

While don Leonardo's family did not expect the maestro to cure their father's cancer, they believed the mesa would alleviate his bodily pain and weakness. Andrés, his mother, and several of his sisters would also participate in the healing ritual. Only the maestro could treat each of their illnesses. Andrés and his siblings had not told anyone outside the immediate family that they were participating this ritual, and they were taking every precaution to keep it hidden from public knowledge. 
The healing mesa is the paradigmatic event of the local practice of brujeria, or sorcery. At one time, Andrés had hoped to apprentice under a maestro. Unfortunately, he lacked the ability to "vision" with the maestro's psychotropic plants. Nevertheless, Andrés knew much about what maestros do and how their curing works. He was an exceptionally articulate and self-reflexive person, and I was fortunate that he trusted me. In addition to giving me a bed in his home and allowing me to participate in his family life, Andrés told me things about brujería that I could not learn from other community members. Nor could I learn about brujería from a maestro directly, because I am a woman. In Kañaris, women do not perform brujería, although they do types of traditional healing.

"I told the maestro that you also want to be cured," said Andrés.

My heartbeat quickened with the invitation to the mesa. Andrés knew that I had come to Kañaris in order to learn about brujería so I could complete my doctoral studies in anthropology, and that this was the event I most wanted to see. This is not an easy topic to investigate in Kañaris. Community members do not like talking about brujería. If an individual cannot avoid answering a question, he or she will likely say that they don't believe in sorcery, and that the maestros are all fakes anyway. But if you stick around long enough and come to be trusted, some people will also say that a maestro cured a condition that no one else could, or that they are sure the sudden death of a family member or their own persistent misfortune was due to brujería.

People in Kañaris generally regard brujeria with a mix of suspicion, incredulity, and resignation towards its existence and efficacy in certain situations. This is to say that it is difficult for an outsider to access. I was excited because I knew this might be the 
only time I would be able to participate in the healing ritual. In fact, in almost two years of fieldwork in Kañaris, I was able to attend only three such events.

Andrés went on to tell me that I wouldn't be able to attend the mesa unless I came to be treated for an illness as well, and that I should think on the condition that I wanted the maestro to treat. He said it should be something "real," some chronic bodily illness or ill-being that I was suffering from. If I tried to "trick" the maestro by concocting a false illness for my participation, the maestro would surely see through my deception. Also, I shouldn't ask too many questions. In his understated yet emphatic manner, Andrés was telling me that I would only be able to attend the ritual as a client and participant: I could not adopt the role of a passive observer or outside analyst. Equipped only with a pencil and pocket-sized notebook, I was being thrown into the mesa.

\section{The first night}

"Tell me what problem you have."

The maestro smiled a little too broadly, already well lubricated with distilled sugar cane alcohol in preparation for the night's work. I was sitting with the maestro at a small wooden table in the cramped room adjoining the larger front room of don Leonardo's house. Andrés had brought me here for a private consultation with the maestro before the ritual session would begin. As is customary during all important conversations in Kañaris, we were taking turns gulping mouthfuls of the strong, clear distilled alcohol called yonqe from a small glass. A bare light bulb created a small bubble of warm light hanging from the low ceiling above our heads. It faintly illuminated a substantial collection of ponchos, jackets, hats, photographs, and election posters hanging 
on the dirt brick walls. Grandchildren's clothes, woven blankets, and leftover dry corn kernels lay strewn over the narrow wooden benches. A son-in-law's dusty computer sat on a small, cluttered desk in the corner, silent and unusable.

I babbled for several minutes attempting to articulate an illness that I hoped the maestro would deem treatable by his mesa. This amounted to the emotional malaise of a graduate student just beginning fieldwork: my disorientation and lack of focus; my frustration with my apparent inability to achieve goals; my lethargy, fogginess, and looming depression. The maestro was at once medical doctor, psychologist, and priest, attentive to clues of how to make a diagnosis and undertake treatment, eliciting private sentiments and secret confessions, listening but not passing judgement.

"It's not that serious," said the maestro. "But I will do what I can."

We returned to the sitting room, which the family had already prepared for the night. They moved two wooden tables to the left side of the room and stacked shovels and other field tools in the corner. They pushed low wooden benches against the three other walls, and laid sheepskins, thick woollen blankets, and foam mattresses on the packed dirt floor. On the far side of the room opposite the back door, the maestro was setting out his ritual table on a white sack on the ground. He positioned it against the eastern wall in the right-hand corner of the room.

Don Leonardo and his wife were comfortably sitting on sheepskins and blankets next to the maestro's ritual table. Several of their grown children and young grandchildren had also come: Andrés and his wife Isabel, two of his sisters with their husbands, his brother and another brother-in-law, and several of his sisters' children. 
They were sitting on low wooden benches along the walls or wrapped up in thick blankets on mattresses and sheepskins on the floor.

I sat on the edge of a mattress with Andrés' youngest sister, Ana. She told me she has a persistent problem with her eyes, and this is what she wants the maestro to cure. She has very strong headaches, blurred vision, and sensitivity to sunlight. Her mother suffers from this same condition, and she is going blind. I often saw both of them with the wide brims of their woven straw hats pulled down low, their eyes half closed as if it hurt to open them. Ana had gone to several medical doctors in the city, but they all said there was nothing wrong with her, except maybe a vitamin deficiency and that she should take a vitamin supplement. This had no effect, however. Ana's mother had also consulted various doctors and tried every herbal remedy, but to no avail. Ana and her mother hoped that the maestro could divine what was causing their eye condition. She suspected someone had perpetrated witchcraft against them. People in town were envious of the prosperity of their fields and good condition of their houses.

As I chatted with Ana, the maestro continued to arrange the objects on his ritual table while drinking yonqe with his assistant. The ritual table consisted of a large, white plastic rice sack slit open and laid out on the ground with numerous objects carefully arranged on and around it. At the head of the ritual table, leaning against the bench along the wall, there were eleven rapier swords and wooden staffs, each two or three feet long. On top of the sack there were several large, smooth stones, ranging in size from a large zucchini to a medium-sized pumpkin. There were also numerous smaller stones, one halfcarved in the shape of a bull, another that appeared to be an archaeological artefact, and several palm-sized ones, some with carvings. 
The ritual table had many more objects, such as metal and stone figurines (a rooster, dragon, bear, frog); two crucifixes, one wooden and the other metal; fragments of metal tools; and two small sheathed daggers, one of which was don Leonardo's. There were several shells, including a furled one, a flat one, and a spoon-shaped one; a small horn cup and a hollow metal stake-like object; and a large wooden cup, a medium stone cup, and a small stone cup. A metal rattle on a wooden handle was next to a metal bell. There were also bottles and jugs of special substances: several small soda pop bottles of yonqe, one of which contained a variety of herbs; various small bottles containing commercially-produced floral waters; and a bottle of red wine. There was a small jug of water mixed with ground white corn; another jug of water mixed with white flower petals; and several lemons and limes, with a lemon juicer and a jar of white sugar. There was also a pot of tobacco leaves mixed with yonqe and floral waters, and a metal teakettle with a prepared liquid mixture of the cactus called San Pedro.

From time to time, the maestro looked at his watch. He was waiting for the appointed hour to arrive, which was nine o'clock. Only then did the mesa ritual begin.

\section{The mesa as ritual event and as table}

The maestro works during an all-night ritual session called the mesa. He works with a collection of sacred objects laid out on a cloth on the ground, and locals also call this the mesa. The straightforward translation of this Spanish term is "table," but with the pronunciation of Quechua speakers, mesa can sound more like misa, or "mass" (see also Gose 1994: 197). This indexes the lexical and conceptual slippage inherent in brujería. While the mesa table refers to the collection of objects used to heal and communicate 
with place-based spirits, the mesa event resembles a Catholic mass. It is set apart from everyday life, during which the ritual specialist (the maestro or sorcerer) communicates with divine figures on behalf of non-specialists (lay people). For the sake of clarity, I refer to the ritual event as the mesa, and the collection of sacred objects as the ritual table.

Although the table is on the ground, it is an altar, for it is the place where the spiritual power of the encantos becomes manifest in this world (see also Polia 1996: 426; Sharon 1978: 72). The maestro calls the power-objects and substances that make up his ritual table artes ("arts"), which points to their esoteric power. For the sake of clarity, I refer to these items as "power-objects." Through these objects, the maestro astutely directs the power of the encantos so as to bless and heal, or curse and harm. They each have secret names known only to him, such as that of an animal or demon that "eats" the illness.

The maestro's principal power-objects are his rocks, swords, and staffs. The rocks are repositories for an immaterial substance that is the power of the encantos. Each rock is linked to a particular mountain or high-altitude lake. A maestro can use only a rock to cure illnesses that came from that same encanto. Maestros call the rocks rayas ("rays" or "lightning bolts"), which refers to the way the power of the encanto is said to travel between the ritual table and its high-altitude origin: like a bolt of lightening.

The narrow metal swords and sturdy wooden staffs are also repositories for the power of particular encantos, and act as mediating conduits to them. Maestros call them lanzas ("lances" or "spears"), which suggests that they use these power-objects in defensive and offensive ways. Andrés told me that while a maestro uses the rocks 
("rays") to treat any type of illness attributed to the power of the encantos, he uses the swords and staffs ("lances") specifically to treat illness due to witchcraft.

The ethnographic literature similarly describes the power-objects used in brujeria as "arts" in general, and the swords and staffs as "lances" (see Glass-Coffin 1998: 20; Polia 1996: ch. 10). But Andrés also used Quechua terms to differentiate between different kinds of power-objects. As I mentioned in the previous chapter, a maestro may have either the koteqa or iya of an encanto. The koteqa has the same "potential or force" as the given encanto, while the iya contains its shadow-soul, the sombra. Andrés told me that the rocks, swords, and staffs are the koteqa, and therefore can be used to "block" or "fight against" the power of the encanto that is causing an illness. Because they contain the same power as a specific encanto, they can "draw out" the invisible substance from the client's body, which the maestro can then "dispatch" or "send back" to that placebased spirit.

The iya, on the other hand, is an iconic figurine that physically resembles the generative force it is spiritually connected to. As we saw in the chapter on different types of mesas, these power-objects are used to treat certain illnesses (such as "surrounding corn"), as well as "raise" a client's luck in agriculture, herding, or business. Thus they seem to function in a similar way as the amulets and figurines of herding animals documented in the southern Andes, which go by several names, including illa (see Allen 2002: 37, 41, 43; Gose 1994: 205-207; Isbell 1978: 151; Salazar-Soler 2006: 254). Ethnographers generally describe these figurines as the animals owned by the mountain spirits, which are fed coca leaves and corn beer during household fertility rituals. But Peter Gose also suggests that illas are connected to the ánimo - or the "soul that provides 
vitality, senses, and animation" - of whatever it represents (1994: 206, 299). The Kañarense iyas may therefore be categorized according to a wider Andean cultural notion of "objects that concentrate special generative powers in themselves" through their “intense concentration" of a "vivifying energy" (Allen 2002: 37, 43).

The maestro also uses other objects and substances for specific purposes. He shakes the rattle (and occasionally bell) while singing sacred songs to the encantos. San Pedro helps him enter the hidden spiritual world and envision how to cure his client. Tobacco "fortifies" the power-objects while they are being used, at the same time as it "raises" the client. And yonque and floral waters "refresh" the encantos through the power-objects they are connected to. We will examine these and other ritual actions as don Leonardo's mesa ceremony unfolds.

\section{Refreshing the table}

The maestro began without any announcement or introduction. He sprayed several mouthfuls of the yonqe mixed with plants over his ritual table in a fine mist through his pursed lips. He also sprinkled the ritual table with ground corn water. Now everyone quieted their conversations and directed their attention towards the maestro, for he was "refreshing" (refrescar) his ritual table and "waking up" (despertar) the swords, staffs, rocks, and other power-objects.

He gave us a couple of drops of two substances for an initial cleansing: first a commercial perfume called "Tabu" in our left palms, and then the yonqe mixed with plants in our right palms. Each time, he instructed us to rub our hands together rapidly 
and then cup them over our mouth and nose, breathing in deeply through our nostrils. Then we vigorously rubbed our faces with our palms like the maestro did.

Now the maestro returned to his ritual table, sitting in a low wooden chair and hovering over his power-objects. He took up his metal rattle and shook it steadily and vigorously. He began to hum lowly, his attention totally focused on what he was doing, as if he were starting out on an inward journey. His humming developed into a mumbled singing in time with the rattle. He sang low and indistinctly, for his songs were for the encantos, and lay people cannot know them. He sang to "wake up" his power-objects, and call to the encantos connected to the rocks, swords, and staffs to be present on his ritual table.

After several minutes, the maestro started to whistle through his lips. He continued to rhythmically shake the rattle as he whistled, and then he whistled into the uncapped top of a small bottle of commercial floral water. He took small mouthfuls of this floral water and sprayed it over his sacred power-objects. He blew yonqe and floral waters over the ritual table to "refresh" the encantos. He made this offering so that the encantos would allow him to use their power.

The maestro cleared his throat and growled a low incantation. I thought I heard him say "Vamos a ver" ("We will see"). He tapped several of the power-objects three times with the bottom of the bottle of floral water. He addressed the specific encantos with whom he has ritual pacts and called them by name, names such as Shin Shin, Chorro, Capitán, Zanawaka, Kutilla.

Next, the maestro instructed each of us to take a mouthful of the yonqe mixed with plants, and spray it out the back door. These plants included certain leaves, bark, and 
herbs from the forested mountains. We drank and blew this special yonqe to be "strengthened" and "familiarized" with the ritual table.

We sat down again, and the maestro gave each of us one or two mouthfuls of yonqe to drink. He must have mixed something else with the yonqe - perhaps some San Pedro - for I soon felt the urgent need to shit. I wasn't the only person who had to make several trips to the outhouse in the backyard over the course of the night. Each time we left the enclosed sitting room, the maestro instructed us to take a sword or staff with us from the ritual table. We were now in a sacred space, set apart from the everyday world with neighbours who were going to sleep, doors and shutters closed to outside attention, vulnerable to outside forces.

\section{Extracting and dispatching illness}

The maestro treated don Leonardo first. He placed a large stone shaped like a bull and another smooth, roundish rock on his chest and stomach. Normally the client holds the stones themselves while standing up, but don Leonardo was very weak, so Andrés and his brother held them while their father remained lying down. They had to keep the stones lightly touching their father, gently pressed against his clothed body in the specific places that the maestro had indicated.

The maestro heals illness by "drawing out" (sacar) or extracting the encanto's power from the body of the client. He asks his encantos what spiritual power is contributing to the client's illness, and what objects and actions he must use to extract it. If he has a power-object that is connected to that specific encanto, he can treat the client's illness. He places the appropriate rock, sword, or staff in the specific locations where he 
has "seen" the illness-causing substance is lodged in the client's body. As the object comes into physical contact with the person, the power of the encanto transfers from the individual to the rock, sword, or staff.

Don Leonardo's sons held the rocks over his body for ten or more minutes while the maestro and his assistant continued to work. The maestro sang and shook his rattle over the ritual table. From time to time, he sprayed floral waters over his power-objects and don Leonardo. His assistant helped him by drinking shot-sized servings of tobacco through his nose. I thought I heard the maestro say this was for the "twelve thousand accounts," but I couldn't be sure. Douglas Sharon notes three such “accounts" while taking tobacco on the coast, each to activate different fields of the ritual table (1978: 171172). In his interpretation, the "accounts" refer to significant numbers in the Catholic symbolism of the mesa, multiplied by one thousand or ten thousand to increase its efficacy in activating the forces of good and evil (Ibid.).

After the assistant had taken tobacco approximately eight times, he swept first one stone and then the other downwards over don Leonardo's body. In this way, the assistant moved the illness-causing substance from this world into the inner, "underworld" of the encantos. He then had to dispose of the "damaging" substance now contained in the stones. The assistant took both of them out the back door. He held first one and then the other heavy rock in his hands, gave it two strong swings in the air, spun around counterclockwise, and made two firm stomps with his feet in the direction of Cerro Kutilla, north of town. He ended this coordinated action by forcefully blowing out through his mouth. 
In this manner, the maestro's assistant "dispatches" (despachar) and "throws" (lanzar) the immaterial illness-causing substance back to its source. He sent the power of the encantos shooting across the sky, "like a lightening bolt," to distant mountaintops and other prominent landmarks. He turned around counter-clockwise to further unbind the power from the object, and he emphatically stamped his foot and expelled his breath to reiterate his intention to direct the power of the encanto away from the client. He told the illness-causing power to go over mountaintops and deserted fields, so as to not cause illness to helpless bystanders. Animals or people who happen to be out at that hour can become accidentally contaminated and sick if they are in the path of the encanto's "shooting rays."

The maestro and his assistant treated the rest of us to a similar procedure. Ana held three short swords in a fan-like arrangement at her chest. Her brothers helped their mother by placing two large stones on her chest and two medium-sized stones over her eyes. Andrés' other sister grasped two large stones to her chest. Isabel held three short swords as a cross reaching outwards from her chest. I held a bundle of bones sewn into a black cloth with a hollow metal stake crossed at my chest. One of don Leonardo's sonsin-law also helped me by placing a large stone on the crown of my head. Andrés grasped a large stone to his left shoulder and another to his chest. His brother held a large stone on the nape of his next. For each client, the maestro or his assistant consumed eight servings of tobacco, rubbed the power-objects downwards over the person's body, and then brought the rocks, swords, and staffs to the backyard to "dispatch" the invisible substance back to the encantos. 
In summary, the maestro uses the power-objects to "draw out" the illness-causing substance from the client's body. The rocks, swords, and staffs are mediating conduits for the immaterial substance that is the power of the encantos in its sickening form. Through physical contact, the "damaging" substance moves from the client's body, where it has been causing illness, to the object, which is spiritually linked to the encanto. Then the maestro "dispatches" the immaterial substance, sending it shooting across the sky to be reintegrated with its supernatural source.

\section{Raising tobacco}

While don Leonardo's sons held the rocks over his body, and the maestro "refreshed" and sang to the encantos, his assistant nasally ingested tobacco. These are tobacco leaves soaked in yonqe, commercial floral waters, and water combined with ground white corn. They are likely fresh tobacco leaves, as the plant grows in Kañaris. Andrés later told me that some maestros make tobacco just with corn water, while others add yonqe and floral waters so the encantos "accept it as something tasty." In this sense, tobacco is another ritual offering, much like the "refreshing" yonqe and floral waters that the maestro blows over the ritual table.

The maestro's assistant used a shell to fill a small horn cup with tobacco. He quickly and lightly tapped the bottom of the cup several times on the stones the sons held on don Leonardo's head and stomach, just as the maestro had done with the bottle of floral water for the power-objects on his ritual table. Then the assistant mumbled a short incantation, which resembled the maestro's earlier one. He tipped his head to the side slightly, held the horn cup close to one nostril, and lightly sucked in the liquid. He nasally 
ingested the acerbic liquid, which caused him to emit long, gurgling belches. He did this eight times, alternating left and right nostrils. Andrés later told me that the left nostril is for "evil," and the right nostril is for "good." That is, the left counteracts the encanto's power in its sickening form, and the right bestows the same power for divine blessing.

Tobacco (Nictotiana sp.) is one of the most important substances used by maestros. It gives strength to the rocks, swords, and staffs that are connected to specific encantos. When these power-objects are placed on the client's body and the maestro or his assistant takes tobacco on his or her behalf, the objects extract the power of the encantos in its "damaging" or sickening form. In order to cure the illness, this immaterial substance must be "drawn" out of his or her body and sent back to its supernatural source. Once the client has been cleansed, the maestro can redirect the power of the encantos to client's body to bless and contribute to his or her well-being.

Maestros call this ritual consumption "raising" (levantar) tobacco, and the action of nasal ingestion "snuffing" (singar, from the Quechua "singa," nose, and the Spanish gerund "-ar"). But these actions do not simply refer to the physical process of bringing a receptacle of tobacco up to one's nose and sucking the liquid in. The maestro and his assistant take tobacco on behalf of the client, and they say it "fortifies" and "strengthens" (fortalecer) the client, even when the client doesn't consume tobacco him or herself. People in Kañaris say that when they are sick, they feel "heavy" or "weighed down," and that when they are healthy, they feel "lighter" and energetic (see also Joralemon \& Sharon 1993: 249-250). The ritual action of consuming tobacco on behalf of the client seems to anticipate this desired change in the client's condition. In this sense, tobacco moves the client's embodied state of being from heaviness to lightness, in an 
orientational metaphor (Lakoff \& Johnson 1980: 14) that mirrors the performance of upward movements from the inner underworld of $u k h u$ pacha to the upper world of hanan pacha (Joralemon \& Sharon 1993: 251-254).

At the same time, "raising" tobacco refers to the role of the person most likely to do it: the maestro's assistant, or "rampador." This term is likely linked to an old Quechua word, rampa, that in pre-Columbian times referred to a type of covered litter used to carry the Inca when he surveyed a region under his jurisdiction (Martínez Cereceda 1995: 98, 55-58, 91-99). ${ }^{15}$ The Inca and his consort sat on special stools on the litter, which symbolically evoked the superiority of sitters over subordinate walkers, and - as hierarchically elaborated stools were an insignia of office - indexed and legitimized the sitter's authority (Martínez Cereceda 1995: 69-78). Several men transported the litter by hoisting the carrying poles onto their shoulders (see Guaman Poma in Martínez Cereceda 1995: 250, 256). On certain occasions, high ranking lords (curacas) and the mummified ancestors (huacas) were carried on similar litters (Martínez Cereceda 1995: 96).

Today, Andean peoples use litters to carry particular saints on their saint days. The bearers lift the saint's platform on their shoulders. From this vantage point, the saint blesses the crowd. The litter-bearers carry the saint for the benefit of the community. It is both a "burden" (cargo) and a sacred responsibility. In the mesa, the assistant or rampador similarly consumes tobacco for the benefit of the client. By ingesting tobacco, he gives strength to the rocks placed on the client's body. The illness-causing power lodged in the client's body is "hungry," and when the assistant consumes tobacco, he is "giving food to the illness." The assistant must finish all the "little plates" of tobacco. If he is unable to withstand the tobacco, perhaps throwing up or leaving even a little behind,

\footnotetext{
${ }^{15}$ I am grateful to Peter Gose for bringing this detail to my attention.
} 
the maestro will not be able to completely cure the client's illness. The assistant "raises" tobacco to "feed" the illness, "strengthen" the rocks, and thus help the maestro "extract" the illness from the client's body.

This was only the opening treatment, however. It was around midnight, and the maestro had to do many more things before the sun would rise around five-thirty in the morning. He steadily attended to his ritual table, shaking his rattle and singing, humming and whistling, and periodically "refreshing" his power-objects with yonque, ground white corn water, and floral waters.

\section{The cactus San Pedro}

Time passed. I lost sense of the order of events and who was receiving what treatments. Sometimes the maestro directed us to blow a mouthful of yonqe out the back door, or take a sip of the strange yonqe mixture from a small stone cup. He would suddenly tell one or another person to stand up, hold a heavy object, turn around, go outside, blow floral waters, or drink more yonqe. All these instructions we blindly followed, neither expecting nor asking for an explanation.

The maestro gave Andrés, his brother, and his two sisters San Pedro to drink. His sisters were very nauseous, and vomited violently into a bucket by the back door. They moaned and uncomfortably lay wrapped up in blankets on the ground. Andrés sat huddled next to his mother, shaking and whimpering. Possibly he was remembering a previous mesa session when he had taken San Pedro, and had terrible visions of huge snakes coming out of the ritual table. That time, his father had to hold onto his poncho to keep him from running off into the night and over a cliff. 
Someone turned on a radio. The maestro continued to shake his rattle and sing, sitting over his ritual table. The lone bare light bulb hanging from the ceiling flickered and dimmed as the electrical current from the town's hydroelectric generator waned. The smells of tobacco and yonqe mingled with the cold night air, the sounds of people moaning and retching, the maestro's rattle and singing, the Andean music crackling from the radio, the steady pattering of rain outside. I continued to have to go to the outhouse, along with several other people, each time protected by a sword or staff.

The liquid that Andrés and his siblings drank contained the mescaline-rich cactus called San Pedro (Trichocerus pachanoi; Echinopsis pachanoi). It is also called "huachuma" or "gigantón" (Polia 1996: 279-280; Sharon 1978: 43). This is a tall, skinny, pillar-like cactus found throughout northern Peru and southern Ecuador, on dry hillsides between 2000-3000 metres above sea level (see Polia 1996: 320-321). It grows near the town of Kañaris in the hamlet of Yoyoque, and it can also be bought in coastal cities such as Chiclayo. Maestros plant San Pedro in secret gardens, away from cilantro or onion. Similarly, the person who cultivates it must abstain from eating hot pepper or onion, or he will "break the strength" of the cactus and leave it "without power."

To prepare San Pedro, the maestro cuts up a healthy stalk into large slices, and cooks it for several hours in a pot of water with another plant called "contrechiso." He fashions a rough wooden cross out of sticks on the spot, sprinkles it with ground white corn water, and places it upside-down in the pot (for a systematic description of the preparation of San Pedro, see Polia 1996: 306-313).

The maestro prepares a specific mixture and administers a dose depending on the strength and requirements of the client. San Pedro is a special plant that has its own 
"spirit." It "tells" the maestro what illness the client is afflicted with, where it is located in the client's body, and what he must do to cure it (see also Polia 1996: 297-298, 305306; Sharon 1978: 115-118). San Pedro also enhances his mystical "vision." The maestro "sees" who has done malicious witchcraft against his client. He also "sees" the illness, most commonly in the form of large snakes. Sometimes the maestro gives the client San Pedro to drink as well. It is purgative, and cleanses the client. Andrés later said that the maestro for his father's mesa was very powerful because he was able to make those who drank it to vomit. Although he didn't want to throw up, he did that night.

Further extraction: Sucking and rubbing

At one point, the maestro and his assistant gave everyone a "sucking" (chupar). They placed their lips directly on the skin of the client and sucked powerfully several times, and then spit out what was in their mouths. Don Leonardo had this at the crown of his head and tops of his feet. Other people had a sucking on their forehead, nape of the neck, upper chest, or backs of their hands.

Through this "sucking," the maestro further extracted the illness-causing substance from our bodies. He held floral water and a small stone in his mouth, sucked at specific regions of the client's body where he had "seen" the illness was lodged, and spit out the water into a cup. The "damaging" power of the encantos moves from the client to the water. The floral water contained several herbs and seeds, as well as "holy water" (probably water combined with ground white corn). The "concentrated" floral water protects the maestro by prohibiting the illness-causing substance he is sucking out from entering his own body. 
Then don Leonardo had tobacco "raised" to him again while his sons lightly held more stones on his body. Because don Leonardo was very sick, he had an additional cleansing with a guinea pig. The maestro rubbed a live guinea pig over him in a downward motion. He didn't examine the small animal, but simply deposited the body of the dead guinea pig in a sack by the back door. This resembled the traditional form of healing called "cleansing with guinea pig." But the maestro was not diagnosing don Leonardo's illness to prepare an herbal remedy. Instead, he used the guinea pig to lessen his client's bodily pain. People in Kañaris say that when an adept practitioner rubs a guinea pig over their body, it extracts some of the illness, and they feel better. The maestro rubbed the guinea pig on don Leonardo to ameliorate the constant pain that accompanied his illness.

Twice throughout the night, the maestro and his assistant gave everyone a fullbody "rubbing" (frotación) with five pairs of swords and staffs. One at a time, the maestro called us to stand in front of the ritual table. His assistant took a specific pair of swords and staffs for each person, crossed them in an "x," and rapped them on the crown of the person's head while mumbling an incantation. Because the intention and determination of the practitioner is crucial during the mesa, the assistant did not lightly tap and whisp the power-objects over the client's body. Instead, he thumped the staffs on each person's head, and then forcefully (and somewhat painfully) swept the staffs down his or her body several times.

He always swept from the head to the feet. It has to be downwards because this is the movement of illness and bad luck. As Douglas Sharon argues, the left side of the ritual table, the left nostril, and downwards motions are symbolically associated with the 
under/inner world - ukhu pacha - while their inverse (right side, upwards motions) symbolize the upper world, hanan pacha (Joralemon \& Sharon 1993: 179). The maestro's downward-sweeping motion of the rocks, swords, and staffs over a person's body serves to move the "negative influences" of the power of the encantos from this world (kay pacha) into parallel spiritual world (ukhu pacha), as previously discussed in the chapter on illness and healing.

Visioning

After all this, there was an extended period of waiting and dozing. The maestro reclined against the wall with his eyes closed. He appeared to be sleeping, but he was not resting. He cannot really fall asleep, for if he does, the "enemy" will advance on the mesa and attack the participants. The maestro was maintaining quiet vigilance while he "visioned" through shamanic dreaming.

Visioning is important to the maestro's practice. It is very likely that the maestro took San Pedro at the beginning of don Leonardo's mesa, since it enhances a practitioner's ability to vision. This is more than the spiritual (or hallucinogenic) world opened up by the psychotropic cactus. For maestros, visioning is not just perceiving a "hidden" reality; it is also the process of interpreting those perceptions and acting in the shamanic dimension on the client's behalf.

According to Andrés, when a maestro "visions," his sombra or shadow-soul exits his body, travels to distant regions, and enters specific encantos. For example, a maestro may dream of a particular encanto. The sombra of the maestro then enters that mountain to talk with the human incarnation of the encanto. Locals always describe the encanto as 
a "white person." The maestro addresses this spirit-person for healing and luck. He offers the spirit refreshment, such as wine or yonqe, "in the same way that one will offer a companion a beer." He pays the encanto a lot so that "his luck will last."

Visioning enables a maestro to "see" spiritual entities or forces that may attack the mesa participants (see also Polia 1996: 120, 133; Sharon 1978: 47). There is always the risk of an attack from an enemy that only a maestro who has vision can see. The "enemy" can be an evil brujo, or the malevolent form of an encanto. In any case, the maestro must be alert to any supernatural forces or malevolent figures who attack the mesa participants throughout the night. To strengthen and protect us, the maestro periodically told us to blow yonqe and floral waters. If we didn't do this, we could "fall" to the illness.

Andrés later told me that the maestro instructed us to blow yonqe throughout the night because "there were some ten illnesses" that came near the mes $a$ and threatened the participants. When the maestro calls to the encantos of his power-objects, the "illnesses also come." In my understanding, this is because the spiritual power of the encantos always has the potential to both cause and cure illness. Blowing yonqe and refreshing the power-objects with floral waters protects the mesa participants from the illness-causing potential inherent in the power of the encantos.

Andrés described the maestro who worked at his father's mesa as one with "good vision" and a "deft hand," who "uses stones to throw a binding spell." As the maestro kept watch over us, I was lulled by the sound of the rain, the strange warmth of the single bare light bulb, the smells of yonqe and tobacco. When the sun was already threatening to rise, around five o'clock, sleep overtook me, and I suspect everyone else. 


\section{The second night}

No one went outside if they could help it. We spent the second day quietly visiting and resting in the sitting room. Once I went back to Andrés' house to brush my teeth, and the maestro told me to take a small stone from the ritual table in my pocket. The men visited and drank yonqe with the maestro and his assistant. The food don Leonardo's wife and her daughters prepared was plainer than usual: clear broth soup, rice, potatoes, and corn without any hot red pepper, lime juice, or salt. People ate sparingly, visited quietly, and generally stayed in their places.

By seven o'clock in the evening it was dark, and everyone settled down for the second night of the mesa. Someone closed the doors and windows that had been open during the day. The maestro began to work again.

\section{Liminal space and time}

First we all received a "rubbing" from five crossed pairs of swords and staffs. After each rubbing, the maestro and his assistant took the swords and staffs out the back door to "dispatch" the illness-causing substance from them. The maestro did this "rubbing" to cleanse us of any influences we had accumulated from the outside world throughout the day. We had to be purified to participate in the mesa.

The mesa is spatially, temporally, performatively, and conceptually set apart from everyday life. It is "sacred” in Durkheim's sense (1961: 52-57) and enveloped in a cultural valuation of separation and secrecy. We had also been in a "liminal" space and time since the start of the ritual the night before. We were "betwixt and between" the 
rhythms and concerns of everyday life (Turner 1969: 95). The world of the mesa inverted the everyday world. The normally immaterial power of unseen and phenomenologically distant supernatural forces now manifested itself through the ritual objects and actions of the mesa. The participants stayed awake all night and rested during the day, the exact opposite of how people normally behave.

Since we were in a sacred and liminal space and time, we had to adhere to certain prohibitions. For example, no one could eat food "seasoned" with fat, onions, garlic, salt, hot pepper, or lime juice. Besides these dietary restrictions, the maestro and all the participants had to refrain from having sexual relations during the time of the mesa. Furthermore, Andrés and his family members did not go to their fields during the day, do household chores, bathe, or even engage in any animated conversations. We were all supposed to rest quietly and remain as close to the ritual table as possible.

Our liminality made us vulnerable to outside factors, such as sunlight and interaction with other people. For this reason, people remained sitting inside during the day. Exposure to direct sunlight, especially at midday, could cause another type of illness. This is "crushing of the sun," and it must be cured with another mesa. We also avoided interaction with people who had not participated in the mesa ritual. Physical contact with other people would compromise our ritual purity. For example, shaking hands to greet other people would "undo everything" that the mesa had achieved the night before.

People also wanted to keep their participation in the mesa secret from other community members. In Kañaris, the mesa is a highly secret event that ideally takes place at the maestro's remote homestead. Don Leonardo, however, was too sick to travel, and 
so the maestro came to him. His mesa was held in his own home, and the family avoided drawing the attention of curious neighbours and extended kin. Andrés and his siblings did not want anyone to know that they were consulting a maestro. In the small town, there is always the possibility that once people know you are consulting a maestro, they will suspect you of doing malicious witchcraft against someone else. If a mesa participant avoids other people, they do not have to respond to any questions about what they have been doing.

\section{Two ritual tables}

We each had a divination with shells. The maestro called me to the ritual table

first. He rubbed two small shells together in his hands and asked me to breathe (not blow) on them, and throw them onto the table on the ground. We did this three times, and at the end he told me that I would need to "raise" tobacco myself at two o'clock in the morning. Everyone else would also receive a specific treatment at a certain time based on their shell divination.

Next the maestro told each of us to blow a mouthful of the yonqe mixed with plants towards the wall opposite the ritual table. One at a time, we stood with our back to the table, faced the wall, and blew out the yonqe through pursed lips as best we could while spinning around. We ended with a firm stomp on the left foot. We did this twice counter-clockwise with our backs to the table, and then once clockwise facing the table.

The maestro set up a second ritual table where we had spun and blown yonqe. It was just bones. There was a black woven grain sack laid on the ground. On top of this 
were bundles of bones sewn into pieces of black cloth. Several larger femur bones were also sitting free.

The maestro called us in pairs of men and women to come before the new table. He called me to stand with one of Andrés' brothers-in-law. He told each of us to take off our left shoe and place our left foot on a large bundle of bones, while each holding a smaller bundle of bones at our midsections. As we stood at the table with the bones, the maestro sat at the first night's table with the rocks, swords, and staffs, rhythmically shaking his rattle and singing in a low voice. Meanwhile, his assistant "raised" yonqe (not tobacco) two times while doing a traditional Kañarense dance called a takiy, turning around in a circle.

"It's bad to look at that," one of the children whispered to me when I was watching another pair at the bone table. Only then did I notice that everyone else was avoiding looking at the maestro's assistant while he raised yonqe and danced.

When he finished, the assistant rubbed the two people standing at the table downwards with the bundles of bones that they each held. Then he took these bundles outside and "dispatched" the illness-causing substance contained in them. The maestro told the two people to come outside with him, where they blew the yonqe mixed with plants two times, first in the easterly direction of the first night's table, and then towards the new table in the west. When each of the adult couples and older children had done this, the maestro quickly disassembled the second ritual table, carefully wrapping the bundles of bones in additional cloths and hiding them in their storage bags.

A maestro has different ritual tables for different types of mesas. At the very least, he should have a table to heal "illness" and a table to undo "witchcraft." By definition, 
the maestro works with the power of the encantos. Both illness and witchcraft ultimately rely on their power. When the immaterial substance of the encanto's power enters a person's body, it has different experiential effects depending on the social context of the power's movement. If a maestro (and his client) intends to harm someone, he wills the encanto's power to cause illness and misfortune. If a maestro instead intends to cure someone, his will directs the same power to effect healing and good luck.

During don Leonardo's mesa, the maestro had the overall intention of diagnosing and healing illness in all of the participants. This was the purpose of the ritual table he had set up the first night, with the rocks, swords, and staffs. The maestro briefly assembled another table the second night to "undo" any witchcraft that was causing illness and other negative effects in the mesa participants. This second table consisted of power-objects that the maestro specifically uses to do and undo witchcraft. Andrés suggested that some of the bones were from animals, and others were human, including a cranium hidden in a black cloth.

According to Andean cultural logic, bones and other remains from pre-Hispanic burial sites are powerful and dangerous. People in Kañaris always identified them as the remains of "gentiles," pre-Christian pagans. Andrés described gentiles as "the first men, primitives," and said their remains are the ruins of pre-Hispanic stone constructions and burial mounds called "huacas." As noted in the previous chapter, the contemporary Andean cultural area is thoroughly Catholicized. People in Kañaris do not consider themselves to be in any way related to the gentiles. They bring illness and misfortune, but the maestro can also use them to counteract witchcraft. 
Andrés described the table with bones as negro ("black") and echoq (left-handed). A maestro uses this type of table in a mesa to either do or undo witchcraft. With the "echoq" table, the maestro raises yonqe instead of tobacco. He doesn't have to follow dietary restrictions, and he can eat seasonings such as garlic, onion, and hot pepper.

A ritual table for healing is the "aya," or "soul" table. Don Leonardo's maestro primarily worked with this kind of table. With the aya table, the maestro activates the power of the encantos in his rocks, swords, and staffs. Through these sacred objects, he collects the invisible illness-causing substance from clients in this world, and sends this power back to the encantos in the parallel spiritual world.

Other ethnographers similarly describe the ritual tables of maestros in terms of dialectical opposites of right/left, positive/negative, day/night and Christian/pagan (see for example Polia 1996: 444-456; Joralemon \& Sharon 1993: 165-171). In addition, the power-objects on the ritual table are typically organized into three fields of left, right, and centre, corresponding to the three worlds of $u k h u$, hanan, and kay pacha (see especially Joralemon \& Sharon 1993: 177-179; Sharon 1978: ch. 6). I was not able to study the details of the maestro's table Kañaris. Moreover, I do not think it is the most relevant thing to investigate, since I am more interested in the social significance of the practice than its abstracted symbolism. But Andrés' distinction between the aya and echoq tables indicates that a similar spatial-moral-performative orientation is present in ritual tables in Kañaris. 


\section{Giving alms}

The maestro and his assistant gave each of us another full-body "rubbing" from five pairs of swords and wooden staffs. Unlike earlier, when they had crossed the swords and staffs, this time they held them parallel. The maestro and his assistant roughly knocked them on the crown of the client's head, and then emphatically swiped the paired swords and staffs downwards, first at the back and then the front. It was an even harder rubbing than the night before, and I caught a couple of people grinning out of the corner of their eyes, letting their companions know that they too could bear it.

Throughout the night, the maestro gave don Leonardo several additional treatments, "raising" tobacco while placing a rock over his body. Afterwards, they rubbed don Leonardo's body downward with the rock and took it outside to "dispatch" the illness-causing substance.

Everyone else, however, was waiting for the hour of their treatment as determined by the shell divination. The maestro presided over the ritual table, shaking his rattle, singing, whistling, and blowing yonqe and floral waters over his power-objects. He told each of us to go out the back door and wash with soap and water. We had to wash our hands three times and our face and mouth two times. After this, he told us to give "alms" of a couple Nuevo Soles to the ritual table.

Why did we have to give money to the ritual table, and why did the maestro describe this in terms of "alms"? The mesa participants were all self-identifying Catholics, and they would have been familiar with giving alms as a small donation given to the Church during the mass. The mesa ritual is a sacred event, but during the second 
night the maestro incorporated actions that suggested he also regarded the mesa as a Catholic event.

A maestro takes on a role very similar to a priest during the mesa session. Only he can communicate with divine powers, and so he mediates the relations between these powers and lay people. But maestros are also morally ambiguous in the eyes of locals, for they can effect good or evil. I am not surprised that don Leonardo's healing maestro would want to associate himself with the morally upright realm of Catholicism. It would be "commendable" at least in the eyes of participants, who would only be self-identifying Catholics. There are Protestant converts in Kañaris, but they are supposed to forswear participation and belief in brujeria and certain other practices that they consider "evil."

By performatively indexing Catholicism, the maestro realigned himself and his practice with community values of social responsibility and solidarity, and distanced himself from the evil practice of witchcraft. He also increased the efficacy of the mesa by suggesting that God (who is a remote, uninvolved figure in Kañaris) either endorses or concedes to it.

But there is another reason for participants to give alms to the ritual table, one that is more autochthonous to an Andean cultural logic. It is that divine powers must be "paid" for what they provide for people (see for example Allen 2002; Gose 1994). The money is not "alms" in the sense that it is for the Church, or God, or even the maestro (whom each client will pay at the end of the session). The money is specifically for the encantos.

This is one of the few instances in which I saw lay people in Kañaris provide an offering or "payment" to a place-based spirit. This is because lay people cannot directly 
communicate with the encantos. Only the maestro is able to address these powerful mountains and high-altitude lakes. He has special ritual "pacts" with them, and so he is obliged to regularly "refresh" the encantos by blowing yonqe and floral waters over the power-objects on the ritual table, which function as a conduit to them. If a maestro neglects to make this "refreshment" and ritual offering to the encantos, they will cause him to fall ill. Encantos rarely address lay people in this manner. Nevertheless, because the mesa participants have directly benefitted from their healing power, they are obliged to "pay" or "offer" the encantos a small amount of money.

\section{How to raise tobacco}

The maestro called me to the ritual table at two o'clock in the morning. He told me to kneel on a folded woollen blanket in front of the table. He gave me a medium-sized stone and two short swords to hold crossed at my chest with one hand. Then he took a hollow metal implement shaped like a stake, and scooped tobacco into it with a shell. The metal receptacle was about $15 \mathrm{~cm}$ long and 3-4 $\mathrm{cm}$ wide. I estimate that it held approximately $70-80 \mathrm{~mL}$ of liquid. Andrés later told me that this metal receptacle is very good to counteract the encantos. People with "vision" see that the illness comes as spears or lightening bolts. This metal receptacle has strength against the shooting rays that are the concentration of an encanto's spiritual power. Because the maestro had good "vision," he could perceive how the illness-causing power of the encantos had entered my body, and how to effectively counteract it.

The maestro tapped the bottom of the metal receptacle on the stone and swords held to my chest while mumbling a low incantation, and handed it to me. Now he told me 
to "raise" tobacco. I knew I had to take the tobacco in through one of my nostrils, but I had little idea of the mechanics involved. I clasped the stone and swords to my chest with my left hand. I held the receptacle of tobacco with my right hand, and brought it to my right nostril while tilting my head back. Some of the liquid entered my nose with a strong, sharp sting. I was afraid to breathe in deeply, as I was sure I would suck it directly into my lungs, so I returned my head to its normal position. Most of the liquid ran down my face and into my jacket collar, but some of the liquid ran down my throat and into my airway, inducing a sputtering cough. Then I doubled over with a strong gag and a dry heave.

Nothing I had read or seen could have prepared me for this experience. I had no control over my bodily reaction. I didn't even have time to register a taste or notion of repugnance before the violent gagging reflex began. Tobacco is a powerful, poisonous plant.

I determinedly tried again. I titled my head back, trying to control my body against the counter-intuitive movement of allowing liquid to enter my nasal passage and actually run down my throat instead of choking on it or letting it soak into my jacket. This time more of the tobacco entered my stomach, and didn't even have time to feel a hint of nausea before I was overcome by a deep retching that seemed to originate in the very core of my being. I was thankful I had not eaten much during the day.

I ingested the tobacco little by little, each time overtaken by uncontrollable gagging, emitting gurgling, wet burps, almost vomiting once in a sputtering dry heave. It was one of the most unpleasant and physically challenging experiences of my life. Eventually I learned that one also has to gulp in some air with the tobacco so that it enters 
your stomach as quickly as possible. The maestro and his assistant are able to do this in long, consecutive swallows, as if the tobacco was merely a pint of beer. And here I was taking little sputtering sips.

It took me a long time to finish my first serving of tobacco. My knees ached from kneeling on the rocky floor, my arm shook with the strain of holding the stone and swords crossed at my chest, my eyes watered, and I was drenched in a cold sweat. I was surrounded by the smell of tobacco, slightly floral and medicinal. I was vaguely aware of the actions of people around me. The electricity had gone out, and it was dark except for the intermittent beam of a flashlight someone was using. The maestro was singing and shaking his rattle beside me. Now one of Andrés' sisters was raising tobacco as well, and I could hear her retching violently into the bucket behind me. Someone turned on the battery-operated radio. The comforting sound of Andean huaynos again crackled throughout the night.

"Listen to the music, as if you're dancing," the maestro said to encourage me. "Drink it like it's lemonade," he said to someone else.

I worked at this initial serving for about an hour. I know because when I finished, someone noted that it was three o'clock and the hour for someone else's treatment. When I was done, I handed it to the maestro. He shook it out to see if it was actually empty.

"You're stronger than you look," he said with surprise approval. He grinned wide, flashing his metal dentures.

I had no cause for celebration, however, since the maestro immediately refilled the metal receptacle with tobacco, tapped it on the stone and swords still held at my chest while mumbling a low incantation, and handed it back to me. Because my arms were 
weak, I switched the stone and swords to my right hand, took up the tobacco in my left hand, and raised the tobacco to my left nostril. Fortunately, I was able to consume the second serving much quicker, in perhaps a half an hour. I had acquired some of the basic mechanics of "raising" tobacco, and I didn't throw up. Nevertheless, I continued to gag and double over with intense dry heaves. Andrés later told me that the maestro gave me a lot of tobacco and that I was strong to withstand it. He himself cannot nasally ingest tobacco and instead takes it by the mouth. But tobacco is more effective when you take it by the nose.

When I finished the second serving of tobacco, the maestro told me to stand up. Someone took the stone and swords from me and rubbed them over the front and back of my body in a downward-sweeping motion. I returned to my perch on one of the low wooden benches, where I fell into a light sleep. Other people continued to work, and then they also rested and waited, lulled by the sound of the rain pattering outside.

When the maestro or his assistant "raises" tobacco on behalf of the client, both the power-objects and the body of the ritual practitioner physically mediate the relations between the lay person and the encantos. In this instance, however, the maestro instructed me to "raise" tobacco myself. This provided a more direct, immediate, and therefore efficacious exchange of power between my body and the objects I was holding. It is difficult, but it is also ontologically more effective.

\section{Flowering}

At about five o'clock in the morning, the maestro called each of us to the ritual table one at a time. He told us to kneel before the table with a white kerchief tied around 
our neck and draped over our left arm in front of our body. We had to hold several objects in the crook of our left arm. The maestro gave me two medium sized stones, a crucifix, and a large magnet. Then he instructed each of us to "raise" five servings of floral water mixed with ground white corn, white flower petals, lime juice, and white sugar. This was much easier than the tobacco I had taken earlier in the night. He gave men the floral water in an upturned hollow bell, and women the floral water in a flat, palm-sized shell.

This was the "flowering" (florecimiento), a final blessing for all the participants, with a "sweet" offering for the encantos. At the same time, we had to hold a collection of objects in a white kerchief in the crook of our arms. I didn't have such a cloth, and no one would lend me one as I would then be "dancing with another's cloth." The kerchief is part of the blessing for the individual; if I used someone else's cloth, it would negate that individual's blessing. Perhaps people described this as "dancing" because such cloths are sometimes used by locals when dancing in the manner of a coastal dance called the marinera. The objects I held attracted or "drew" the power of the encantos to me, this time with the beneficial intention of conferring their divine favour and protection, and bestowing "good luck."

When I finished the floral water, the maestro tapped the shell on each of the power-objects I was holding. He took them from me, and rubbed them over my sides and head in an upward sweeping motion. When the maestro and his assistant had previously "raised" tobacco, they had swept the power-objects over my body downwards, from my head to my feet. This extracted the illness-causing power of the encantos from my body. This time, the "rubbing" was in the opposite direction, and with the inverse intention. The 
maestro swept the power-objects over my body upwards, from my trunk to my head. This directed the holy power of the encantos to me, in order to bring blessing and good luck.

After everyone had "raised" the floral water and had their final "rubbing," the maestro blew floral waters over the ritual table one last time. Then he gave each of us a small serving of yonqe from a stone cup. He told us to stand together in a circle, with all our hats laid on the ground in the middle and turned upside down. The maestro sprinkled all the participants and their hats with ground white corn water. He led us in reciting a foundational Catholic prayer called the Apostle's Creed:

I believe in God the Father almighty, creator of heaven and earth. I believe in Jesus Christ, his only Son, our Lord. He was conceived by the power of the Holy Spirit, and born of the Virgin Mary. He suffered under Pontius Pilate, was crucified, died, and was buried. He descended to the dead. On the third day he rose again. He ascended into heaven, and is seated at the right hand of the Father. He will come again to judge the living and the dead. I believe in the Holy Spirit, The holy Catholic Church, The communion of saints, The forgiveness of sins, The resurrection of the body, And life everlasting. Amen.

And with this declaration of faith, the mesa session ended.

The final sequence of actions of the mesa resembled a simplified version of the Catholic mass. We all received a serving of yonqe, the distilled liquor that had been like our Holy Communion for the past two nights. The maestro sprinkled us with ground white corn water, which bestowed blessing, and which was our holy water. Then he led us in reciting the prayer in which Catholics reiterate the basic tenets of their religion. 
Even I, a lapsed Catholic, am able to recite this prayer in Spanish once other people have begun.

The communal declaration of Catholic belief reoriented mesa participants to the morally upright intentions of the ritual to heal and bless. This prayer is a part of every Catholic mass, where it takes place after reading the scriptures and listening to the sermon, to signal the beginning of the Eucharistic celebration of Holy Communion. The fact that everything we had engaged in for the past two nights was inconsistent with this stated Catholic belief didn't seem to bother anyone. We had also taken our communion in the yonqe and received our divine blessing with the "flowering." Sunlight was beginning to creep in under the doors and through the wooden shutters of the windows. I imagine that all the self-identifying Catholics present felt a similar sensation to the one I had: That the mass was ending, we would exit the church renewed, and the world would return to its normal pace.

\section{Denouement}

Don Leonardo's family asked the maestro to do a mesa because their father had cancer. According to Andrés, the family didn't believe the maestro could cure their father's cancer, which they recognized as a disease that only biomedicine could treat. However, they hoped the mesa would alleviate don Leonardo's bodily pain, cleanse him of bad luck, and bestow him with good luck. While the maestro used sacred rocks to treat his bodily pain and disease, he could do nothing for the cancerous tumour visible on don Leonardo's neck. 
The maestro also used rocks, swords, and staffs to treat several of don Leonardo's grown children. They were each suffering from an illness or chronic condition that they attributed to witchcraft - intentionally harmful ritual actions that someone in the community had perpetrated against them. I don't know if any of the participants were cured of their conditions after the mesa. Don Leonardo died eight months after this event, three days before Christmas 2011. Even though he was only in his mid-sixties, his death could not have been a surprise to the family, as they knew that he had decided to forgo another expensive operation and further medical treatment in the city. I was not in Kañaris when he passed away, but as I saw during the second funerary rite in June 2012, his children were deeply affected by their grief.

The last time I saw don Leonardo, he walked very slowly to the courtyard outside his home. It was a sunny afternoon, but he was bundled in a sweater, poncho, scarf, and wool hat. His daughters had asked me to take photographs of them with him. He was a man of great strength, integrity, and knowledge, and I am grateful to have known him the little that I did.

\section{Chapter conclusion}

Don Leonardo's mesa included all the ritual actions and objects that other ethnographers have documented as part of the performance of healing in brujeria. The maestro sang sacred songs to call upon specific encantos embodied in mountains and high-altitude lakes. He "refreshed" the encantos he was communicating with by blowing sugar cane alcohol and floral waters over the power-objects on his ritual table. The maestro and his assistant placed sacred rocks, swords, and staffs on each of the client's 
bodies to draw out the power of the encantos in its sickening form. Through physical contact, rubbing, and sucking, the maestro transferred the immaterial substance from the bodies of the participants to the power-objects, and then sent this substance back to its spiritual source. The maestro and his assistant strengthened this process by nasally ingesting tobacco. He also consumed San Pedro to facilitate his shamanic visioning, and he directed certain participants to take this same mixture to further purge them of illness.

The mesa was the most "sacred" event I ever observed in Kañaris. The participants gave their full attention to the officiant for an extended period of time. Neither men nor women engaged in other activities during the two nights of the mesa. No one talked in whispers to the person next to them, and no one came or went as they pleased. Even the children picked up on the reserved behaviour of the adults, and sat quietly or fell asleep. In my experience, locals didn't maintain this sort of deferential attention during secular events or community rituals, and certainly not during Catholic mass. The mesa is the true mass in Kañaris.

The maestro concluded don Leonardo's mesa with a communal recitation of a foundational prayer of Catholic belief and faith. This shifted the focus of the mesa from the parallel spiritual world of the encantos back to this world, the human world, inhabited by normatively Catholic community members. Through the two nights of the mesa ritual, we had occupied a liminal state in between the human and spiritual world. The ritual actions of the mesa worked to cleanse us of sickening mal, and uplift our sombras with beneficent power of the encantos. We were firmly grounded in this world, kay pacha, once again. Now we reaffirmed our participation in the community. We were ready to return to our daily tasks and concerns with a restored state of being. 


\section{Conclusion}

In Kañaris, brujería is a practice of both ritual healing and malicious witchcraft, using the power of the encantos, through the mediation of the sorcerer. I have made an heuristic distinction between "sorcery" and "witchcraft" to highlight the moral evaluations Kañarenses make of people who are doing this practice. Sorcery is the "morally commendable" (Londoño Sulkin 2012) practice of brujería in order to heal bodily illness and embodied ill-being, cleanse a client of bad luck, and bestow the client with the beneficent power of the encantos to raise their state of normatively good luck. Witchcraft is the "morally despicable" (Ibid.) practice of using this same spiritual power to cause illness and misfortune, and harm a victim by contaminating them with the power of the encantos in its malevolent mode.

People in Kañaris use the term brujería to refer to both sides of this practice. They do not, for example, differentiate between witchcraft, magic, and sorcery (or "bad magic") in the Azande sense of mangu, ngua, and gbegbere ngua (see Evans-Pritchcard 1976: 176-189, 226-228). Indeed, while E. E. Evans-Pritchard demonstrates that witchcraft and magic/sorcery refer to distinct fields of practice in Zandeland - witchcraft works through the witchcraft-substance contained in the body of certain people, and good and bad magic work with herbal medicines and spells -, in Kañaris, brujería encompasses directing the power of the encantos with both helpful and harmful 
intentions through the same types of ritual action and by the same ritual specialist. Thus people in Kañaris say that sorcerers "play both sides."

The practitioner of brujería can be described as both a maestro ("master") and a brujo ("sorcerer"). Community members foreground the practitioner's culturally valued and respectable role as a ritual healer when they call him a maestro or brujito ("little sorcerer"). These terms downplay the practitioner's nefarious potential to cause illness, misfortune, loss, and death. For the sake of simplicity, I have favoured the English term "sorcerer" to refer to a practitioner of brujería in general. When relevant, I have distinguished between "good" healing sorcerers as maestros, and "evil" illness-causing sorcerers as brujos.

A sorcerer causes or cures certain classes of illness by directing the power of the encantos towards a specific person with the intention to either help or harm them. He does this during an all-night event called the mesa, using power-objects arranged on a ritual table that are spiritually connected to specific encantos. While people attribute the encantos with individualized names and characteristics, these place-based spirits do not "care" if a particular individual is experiencing well-being or ill-being. They rarely address lay people directly, and community members do not expect the encantos to provide for them in a mutual relationship of obligation and reciprocity, as in the southern Andes. Instead, people must consult a sorcerer if they wish to cure an illness attributed to their power, or be blessed with this same power to increase their productive capacities and state of luck. Only a sorcerer can intentionally communicate with the encantos by consciously separating his sombra from his body and entering the parallel spiritual world they inhabit. 
Through what James George Frazer calls the "law of contact or contagion" (1960: 12-14), the physical contact of the sorcerer's power-object and the client's body "extracts" an immaterial substance from the person. This is the power of the encantos in its sickening form, which the sorcerer then "sends back" to its spiritual source in particular mountains and high-altitude lakes. The power is reintegrated into the encantos and its harmful effects are neutralized. The sorcerer can then direct this same spiritual power to the client to "cleanse" them of bad luck and "raise" their embodied state of good luck. The power of the encantos has different experiential effects in a person's body and the total person in their individual, social, and economic setting depending on the will and intention of the ritual specialist.

A lay person can become sick with the power of the encantos through accidental contamination (e.g. coming into physical contact with power-objects used in a previous healing mesa), or more rarely through a direct encounter with this spiritual entity (e.g. a chance meeting with the human incarnation of an encanto at night; trespassing on an encanto's domain without proper ritual deference). Since direct encounters are rare, and accidental contamination presupposes a previous chain of events, logically a significant number of illnesses attributed to the power of the encantos happen because of witchcraft. That is, this class of illness often happens because of the intentionally malicious ritual actions to harm a person using the encantos' power. While only a sorcerer can do this, he only does witchcraft on behalf of a paying client who wants to harm the person they envy. The socially real perpetrator of witchcraft is thus the envious person, whom people always say is a fellow community member. 
Whether the practice of witchcraft can be empirically verified or not is beside the point. The fact is that people in Kañaris say it happens, and modify their behaviour and evaluations of fellow community members based on this implicit belief. As witchcraft, brujeria is the most extreme action one person can take to damage another. Despite the local cultural ideals of social solidarity, equality, and the reciprocal extension of aid, community members perceive themselves to be vulnerable to the envy and ill-will of neighbours, work partners, and extended kin. People in Kañaris manage this vulnerability through the construction of the house, the distinction between public and private space and knowledge, the ongoing negotiation of trust and intimacy, and avoiding those people and situations in which they experience conflict. From this perspective, brujeria is also the ultimate practice community members can engage in to reestablish the normatively productive and harmonious order of the social world and their place in it.

At the beginning of this dissertation, I claimed that brujeria is meaningful and persists in Kañaris because of three main reasons. First, through diagnosing and healing illness, it provides people with an account for and response to their suffering. Second, by raising a person's luck, it enables people to improve their productive capacities and prospects for advancement, and mitigate their vulnerability to future suffering. Third, by attributing responsibility for their suffering, it tells people something about their relations to fellow community members. In the following sections, I return to these points in light of not just the practice of brujeria, but also the internal social dynamics of Kañarense society. In the process, I hope to demonstrate that brujeria is at once a genre of traditional medicine and a sacred form of communication with spiritual entities. It is a ritual practice that does something, explains something, and creates something. And it is a practical and 
theoretical frame that refers to both the pragmatic and moral concerns of community members.

\section{The praxis of brujería}

In Kañaris, brujería provides people with an account for instances of suffering that resist other forms of explanation, answering questions such as "Why me, why this, why now?" It is also a technique to do something that people cannot achieve by other means, effecting healing, luck, and cursing through different types of mesas. From this starting point, the internal logic and practice of brujería appears to support Bronislaw Malinowski's proposition that magic “is resorted to in those contexts where man's technical control of nature has reached its insufficient limits" (Tambiah 1990: 72). Indeed, people in Kañaris visit sorcerers because they want to achieve something they cannot do themselves: cure certain classes of illness and restore health and well-being so that they can return to their daily tasks and responsibilities, and mitigate their risk to future suffering by being cleansed of the sickening power of the encantos and conferred with this same power in its beneficent form.

But as we have seen, brujería is more than a ritual technique for dominating nature and the "uncontrollable agencies" (Ibid.) that affect the outcomes of an individual's practical activities and spiritual state of being. I follow Stanley J. Tambiah in contending that the more significant contribution Malinowski made to the anthropological study of magic is his insight that it is embedded in a wider social field. Tambiah refutes Malinowski's claim that "magic begins where technology ends" by 
noting that while Trobriand yam gardening is surrounded by magic, coconut gardening is not, and pointing to the work of historians and ethnographers who indicate that magical practices are not maintained or abandoned based on the development of "adequate technical procedures for dealing with a task" (Tambiah 1990: 72-73, 135-137).

Nevertheless, Malinowski's work demonstrates that in the Trobriand Islands, gardening, fishing, and canoe building are regulated and carried out through magical rites, not in the abstract sense of intellectualists such as Edward Tylor and James George Frazer who came before him, but in terms of observable social, economic, and political activities:

[Malinowski] saw how the ritual expert and specialist, by conducting imperative ceremonies, actually thereby mobilized manpower and resources and that the rites served as triggering mechanisms for the sustained conduct of practical operations. (Tambiah 1990: 73)

One does not have to adopt Malinowski's strongly functionalist position to acknowledge that the ways in which magic (or witchcraft, or sorcery) is embedded in the practices and concerns of people in a particular society at once point to and recreate its meaning and relevancy. We have seen that in Kañaris, brujería is tied to not just illness and healing, but a wider sense of well-being articulated alongside luck and production, its inverse in personal envy and social conflict, and ultimately the local moral economy based on material and social equality within the "one big family" of the ayllu of Kañaris, in which people should work together for the benefit of the community as a whole, not private accumulation, and exemplify respect, modesty, and generosity.

This brings us to the second point I raised at the beginning of this section: that brujería provides an explanation for an individual's suffering. The Oxford English 
Dictionary defines suffering as the experience of pain, loss, grief, damage, or defeat. While I do not remember any instances in which my Kañarense interlocutors explicitly used the corresponding Spanish term sufrir, they clearly connected pain, loss, damage, and other unpleasant, undesirable, and abnormal states of being to both the actions of particular people and the existential human condition of uncontrollable, "natural" phenomena that occur independently of human action. Philosopher Susan Neiman (2002) discusses these forms of suffering as an outcome of "moral" and "metaphysical" evil in the Western philosophical tradition.

I hope I have not naïvely suggested that Kañarense categories of experience and thought can be directly translated into Western ones. In the tradition of anthropologists such as Clifford Geertz, I have attempted a “"careful' mapping” of Kañarense understandings onto our own through a "thick description" of local practices and concerns (see Tambiah 1990: 116). At the same time, I follow philosophers such as Alasdair MacIntyre and Hans-Georg Gadamer in assuming that there is some "shared space" of "intelligibility and reasoning" between myself and my interlocutors (Tambiah 1990: 121; see also Gadamer 2004: 292-296). While I must necessarily approach a Kañarense understanding of the world and one's experience of it from my own cultural horizon, I have striven to bracket my pre-understandings and exercise "interpretive charity" in assuming that my interlocutors are rational actors in ways that are partially comparable and commensurable to my own (see Tambiah 1990: 122, 125).

On these grounds, I propose that the praxis of brujeria is meaningful and relevant for people in Kañaris not just because it does something, but because it is articulated within a distinctly Kañarense theodicy, or "explanation of the distribution of suffering in 
this world" (Tambiah 1990: 8). As Neiman says, the broad sense of theodicy "is any way of giving meaning to evil that helps us face despair" (2002: 239). With this issue, brujería dovetails with both philosophy and medicine. For example, Byron J. Good says:

A great many anthropological studies of illness have shown that sickness is universally experienced as a moral event, as a rupture of the moral order that invokes such 'moralizing judgments.' And efforts to bring meaning to such events requires not only resort to theodicy, in Weber's terms, that is to answering 'why me?' (with an implied 'why me rather than him?'), but to the yet more fundamental soteriological issues. What is the nature of this suffering? What is the moral order that makes sense of it? What are the sources for hope to go forward in this context? (1994: 134)

Evans-Pritchard makes a similar argument when he says, "The notion of witchcraft explains unfortunate events" for the Azande (1976: 18ff). In his famous example of the collapsing granary, he says that Zande recognize the wooden supports of a granary can collapse because terminates eat them and they decay over time (1976: 22). Zande also know that people like to sit under granaries during the heat of the day to visit and relax (Ibid.). According to Western understanding, if the granary collapses while people are sitting underneath it, it is merely a coincidence (Evans-Pritchard 1976: 22-23). In the Zande understanding, however, these events are meaningfully linked:

The Zande knows that the supports were undermined by termites and that people were sitting beneath the granary in order to escape the heat and glare of the sun. But he knows besides why these two events occurred at a precisely similar moment in time and space. It was due to the action of witchcraft. If there had been no witchcraft people would have been sitting under the granary and it would not haven fallen on them, or it would have collapsed but the people would not have been sheltering under it at the time. Witchcraft explains the coincidence of these two happenings. (Evans-Pritchard 1976: 23) 
For people in Zandeland, witchcraft explains unfortunate events, and provides not only a means for determining who can be held morally accountable, but also a technique for seeking culturally acceptable retribution. For people in Kañaris, brujería explains sudden or persistent illness that does not respond to other forms of medical treatment, and serious misfortune such as crop and animal loss, business failure, an inability to achieve one's goals, and the death of family members - all locally relevant forms of suffering that cannot be satisfactorily accounted for by other explanations. Unlike the Azande, however, people in Kañaris do not seek to avenge the wrongs committed against them through counter-sorcery. Instead, they verify their suspicion that someone in the community wishes them ill, and use this information to mitigate their vulnerability to future harm that such an individual may perpetrate both socially and magically.

I have suggested that an implicit Kañarense theodicy is partially articulated through the local notion of "luck" (suerte). I have proposed that luck accounts for the unpredictable and uncontrollable distribution of suffering. People indicate that "bad luck" is evil in the triadic sense of the existential human condition, the immoral action of witchcraft, and an immaterial substance called mal ("evil"), which can become lodged in a person's body. Nevertheless, the Kañarense notion of evil does not map directly onto Western notions of metaphysical and moral evil. Luck is not allocated by a spiritual entity according to what a person has done or failed to do. Nevertheless, it is connected to the encantos, since their power can be used to both "curse" an individual with bad luck, and "bless" them by "raising" their embodied state of good luck. At the same time, bad luck is not always the result of witchcraft, for a person can experience illness and misfortune independent of both their actions and the actions of other people. But when it 
is attributed to witchcraft - for example, when an individual is "contaminated" by coming into physical contact or proximity with a "cursing" and "damaging" witcheraft bundle people evaluate this action as morally evil.

The triadic notion of evil in Kañaris - as existential condition, immoral action, and substance - is in turn connected to how community members assign responsibility for suffering. As we saw in the outline of the local medical system, some classes of illness are due to "naturalistic" factors such as sun, wind, rain, tainted food or water, and microscopic organisms. These conditions occur not because of the will or intention of a non-human agent, but because of the encounter between the body and the environment. Such illnesses can therefore be treated by both herbalism and biomedicine. Other classes of illness, however, are attributed to the "personalistic" intention of a human or nonhuman agent to harm a particular person. For example, malos espiritus are categorically malicious. When an individual walks by a place where one of these invisible evil spirits resides, it "frightens" and "grabs" an immaterial part of the person - their shadow-soul, or sombra. Other illnesses similarly affect the person's sombra through "kidnapping" or “contamination." Sometimes these illnesses are caused by spiritual entities themselves, such as malos espiritus, diablos, and even occasionally encantos. In these instances, the illness must be treated by practices that address not just the body, but the state of a person's sombra. Depending on the severity of the condition, this can be a family member who can "call" the sombra back to the victim's body, a local herbalist (remediera) who does "cleansing with guinea pig," or a sorcerer.

With illness attributed to "personalistic" forces, the spiritual entity is expressing and acting on their internally generated intention to harm an individual. Other times, the 
illness is due to the power of an encanto, but has been effected through a human intention rather than the intention of the spiritual entity. This is witchcraft, in which the sorcerer and his client are responsible for causing illness in a specific person. The encanto shares this responsibility, since it participates in a chain of cause and effect that brings about the illness. But the socially relevant responsibility lies with the human actors - and above all, the client who approached the sorcerer in the first place to enact his or her malevolent and evil desire to harm the person they envy.

Brujeria is the practice through which a person can identify and respond to the chain of cause and effect that has brought about their misfortune and suffering, when this suffering is recognized as occurring because of either a human or non-human intention. In this sense, it explains certain classes of illness, provides the curative technique, and is the interpretive mode through which not just causal explanation can be determined, but social and moral responsibility can be made. In Tambiah's terms, people shift between these two paradigmatic orderings of reality: causality and participation (1990: 105-110, 136). Second to healing illness, the participation of human actors is the most significant aspect of brujeria for community members. In this dual sense, brujeria is a practical and theoretical frame that refers to both the pragmatic and moral concerns of community members.

\section{The social significance of brujería}

Anthropologists such as Malinowski and Evans-Pritchard spearheaded the analysis of magic in terms of the wider context of particular societies. I contend that in Kañaris, this is where the social significance of brujería can be located. In this section, I 
draw out an important theme that has for the most part only been implicitly demonstrated so far: the tension between the ideal of solidarity and communalism on one hand, and social fracture and individualism on the other.

At the beginning of this dissertation, I proposed that there is an underlying tension between the individual and collective good in Kañaris. The implicit ideal is that community members should be equal and politically unified. But in reality, resources and power are unequally distributed, and people have diverse interests and divided allegiances. One way this tension is manifested is through an unarticulated but performatively indexed fear of vulnerability to social others. This vulnerability finds its ultimate expression in malicious ritual acts intended to harm a fellow community member - that is, witchcraft.

We do not necessarily have to couch this tension in terms of a characteristically “Andean" value or cultural theme, although ethnographers such as Peter Gose (1991) and Gary Urton (1992) have provided rich ethnographic analyses of, for example, the tension between communal work and private accumulation in the Andes. Instead, I will appeal to Émile Durkheim's notion of social solidarity as he elaborates in The Division of Labor in Society (1933[1893]).

For Durkheim, society is a fundamentally moral phenomenon, concerned with being accountable to other people, and functioning not just through the actions of autonomous agents, but through the interdependence of people who have various types of responsibilities towards one another (1933: 398). From this perspective, morality can be minimally defined as the ways in which people hold one another accountable and responsible to each other, and this is the condition for society: 
Society is not, then, as has often been thought, a stranger to the moral world, or something which has only secondary repercussions upon it. It is, on the contrary, the necessary conditions of its existence. It is not a simple juxtaposition of individuals who bring an intrinsic morality with them, but rather man is a moral being only because he lives in a society, since morality consists in being solidary with a group and varying with this solidarity. (Durkheim 1933: 399)

People in Kañaris demonstrate their interdependence and responsibilities towards one another through kinship ties, work relations, co-parentage, land distribution, the exchange of labour and agricultural products, and other ritual activities. As in any community, these visible signs of social solidarity are just the tip of the iceberg. Below the surface of relative social harmony, material equality, and similar practice and belief, there is a massive bulk of largely unarticulated yet pre-understood meaning. Despite the cultural ideals of hospitality and generosity, trustworthiness and reliability, and respect and humility, people realize that fellow community members do not always behave in normatively "good" ways. Sometimes people transgress local moral values, for example by failing to reciprocate field labour, by being lazy and selfish, by stealing from a neighbour, by doing violence to women or children, or by perpetrating witchcraft.

\section{Hope}

As troubling as the existence of what I have called "moral evil" may be for community members - and the outside analyst - I believe the existence of brujería ultimately points to the hope people in Kañaris have of making sense of their suffering, coming to terms with the evils people do to one another, and applying this understanding 
to their own lives in order to live and work alongside one another once again. In this sense, brujería facilitates the reintegration of the suffering individual back into the whole of society. As Neiman indicates, hope is more powerful than despair. She says, "Belief that there may be reason in the world is a condition of the possibility of our being able to go on in it" (2002: 324). People do not always act as they should, things do not always work out in one's favour, and sometimes we are faced with situations that appear senseless in terms of our present understanding. But if we can survive each other's idiosyncrasies, the vicissitudes of human suffering, and even world-shattering experiences, we can go on living with purpose and meaning, striving to create and participate in a world that is, if not always as it "ought" to be, is at least a moral one. 


\section{Works Cited}

\section{Scholarly books and articles}

Allen, Catherine. 2002[1988]. The Hold Life Has: Coca and Cultural Identity in an Andean Community ( $2^{\text {nd }}$ Ed.). Washington \& New York: Smithsonian Books.

Alva Mariñas, Pedro. 2008. Don Víctor Huamán Reyes: el «cacique moral» de Cañaris. Bulletin de l'Institut Français d'Études Andines 37(1): 257-270.

Århem, Kaj. 1996. "The cosmic food web: Human-nature relatedness in the Northwest Amazon,” pp. 185-240 in Philippe Descola \& Pálsson Gísli (eds.), Nature and Society: Anthropological Perspectives. London \& New York: Routledge.

Aristotle. 2004. The Nicomachean Ethics (trans. J.A.K. Thomson, revised Hugh Tredennick). London: Penguin Books.

Arroyo Aguilar, Sabino. 2004. Dioses y oratorios andinos de Huancabamba: Cosmología y curanderismo en la sierra de Piura. Lima: Fondo Editorial UNMSM.

Barth, Fredrik. 1969. "Introduction," pp. 9-38 in Fredrik Barth (ed.), Ethnic Groups and Boundaries: The Social Organization of Cultural Difference. Boston: Little, Brown and Company.

Bastien, Joseph W. 1978. Mountain of the Condor: Metaphor and Ritual in an Andean Ayllu. St. Paul, MN: West Publishing Co.

Bebbington, Anthony \& Mark Williams. 2008. Water and Mining Conflicts in Peru. Mountain Research and Development 28(3/4): 190-195.

Bebbington, Anthony, Jeffrey Bury, \& B.L. Turner II. 2009. Institutional Challenges for Mining and Sustainability in Peru. Proceedings of the National Academy of Sciences of the United States of America 106(41): 17296-17301.

Bennett, Bradley. 1992. Hallucinogenic Plants of the Shuar and Related Indigenous Groups in Amazonian Ecuador and Peru. Brittonia 44(4): 483-493.

Blakenship, Judy. 2005. Cañar: A Year in the Highlands of Ecuador. Austin: University of Texas Press.

Bourdieu, Pierre. 1990[1980]. The Logic of Practice (trans. Richard Nice). Stanford: Stanford University Press. 
Bouysse-Cassagne, Thérèse \& Olivia Harris. 1987. "Pacha: En torno al pensamiento Aymara," pp. 11- 59 in Thérèse Bouysse-Cassagne, Olivia Harris, Tristan Platt, \& Verónica Cereceda, Tres reflexiones sobre el pensamiento andino. La Paz: Instituto de historia social boliviana (HISBOL).

Brown, Michael. 1986. Tsewa's Gift: Magic and Meaning in an Amazonian Society. Washington \& London: Smithsonian Institution Press.

Brubaker, Rogers \& Frederick Cooper. 2000. Beyond "identity." Theory and Society 29: $1-47$.

Burger, Richard. 2008. "Chavín de Huántar and Its Sphere of Influence,” pp. 681-703 in Helaine Silverman \& William H. Isbell (eds.), The Handbook of South American Archaeology. New York: Springer Science+Business Media.

Burgos Guevara, Hugo. 2003. La Identidad del Pueblo Cañari: De-construcción de una nación étnica. Quito: Abya-Yala.

Bury, Jeffrey. 2004. Livelihoods in Transition: Transnational Gold Mining Operations and Local Change in Cajamarca, Peru. The Geographical Journal 170(1): 78-91.

Bussmann, Rainer \& Douglas Sharon. 2006. Traditional medicinal plant use in Northern Peru: Tracking two thousand years of healing culture. Journal of Ethnobiology and Ethnomedicine 2(47): np. Open Access: http://www.ethnobiomed.com/content/2/1/47.

Camino, Lupe. 1992. Cerros, Plantas y Lagunas Poderosas: La medicina al norte del Perú. Piura: CIPCA.

Canessa, Andrew. 2012. Intimate Indigeneities: Race, Sex and History in the Small Spaces of Andean Life. Durham \& London: Duke University Press.

Castillo Butters, Luis Jaime \& Santiago Uceda Castillo. 2008. “The Mochicas," pp. 707729 in Helaine Silverman \& William H. Isbell (eds.), The Handbook of South American Archaeology. New York: Springer Science+Business Media.

Cervone, Emma. 2012. Long Live Atahualpa: Indigenous Politics, Justice, and Democracy in the Northern Andes. Durham \& London: Duke University Press.

Colloredo-Mansfeld, Rudi. 2009. Fighting Like a Community: Andean Civil Society in an Era of Indian Uprisings. Chicago: University of Chicago Press.

Cook, Noble David. 1982. Population Data for Indian Peru: Sixteenth and Seventeenth Centuries. The Hispanic American Historical Review 62(1): 73-120.

Crandon, Libbet. 1983. Why Susto? Ethnology 22(2): 153-167. 
Crandon-Malamud, Libbet. 1991. From the Fat of Our Souls: Social Change, Political Process, and Medical Pluralism in Bolivia. Berkeley \& Los Angeles: University of California Press.

Crespo Toral, Hernán. 2003. Desde la penumbra. Un retrato del exilio o la presencia de los cañaris en el Cusco. Revista Española de Antropología Americana. Vol. extraordinario: 277-290.

Csordas, Thomas. 1994. The Sacred Self: A Cultural Phenomenology of Charismatic Healing. Berkeley: University of California Press.

Csordas, Thomas. 1996. "Imaginal Performance and Memory in Ritual Healing," pp. 91113 in Carol Laderman \& Marina Roseman (eds.), The Performance of Healing. New York: Routledge.

Csordas, Thomas. 2008. Intersubjectivity and Intercorporeality. Subjectivity 22: 110-121.

De la Cadena, Marisol. 2000. Indigenous Mestizos: The Politics of Race and Culture in Cuzco, Peru, 1919-1991. Durham \& London: Duke University Press.

De la Cadena, Marisol. 2010. Indigenous Cosmopolitics in the Andes: Conceptual Reflections beyond "Politics." Cultural Anthropology 25(2): 334-370.

Descola, Philippe. 1996[1993]. The Spears of Twilight: Life and Death in the Amazon Jungle (trans. Janet Lloyd). New York: The New Press.

Dobkin de Rios, Marlene. 1972. Visionary Vine: Hallucinogenic Healing in the Peruvian Amazon. Prospect Heights, IL: Waveland Press.

Dransart, Penny (ed.). 2006. Kay Pacha: Cultivating Earth and Water in the Andes. Oxford: Archaeopress.

Dulanto, Jalh. 2008. "Between Horizons: Diverse Configurations of Society and Power in the Late Pre-Hispanic Central Andes," pp. 761-782 in Helaine Silverman \& William H. Isbell (eds.), The Handbook of South American Archaeology. New York: Springer Science+Business Media.

Durkheim, Émile. 1933[1893]. The Division of Labour in Society (trans. George Simpson). New York: Macmillan Company.

Durkheim, Emile. 1961[1912]. The Elementary Forms of the Religious Life (trans. Joseph Ward Swain). New York: Collier Books.

Espinoza Soriano, Waldemar. 1975. El Valle de Jayanca y el Reino de los Mochica, Siglos XV y XVI. Bulletin de l'Institut Français d'Études Andines 4(3-4): 243-274. 
Espinoza Soriano, Waldemar. 1978a. "Los Chachapoyas y Cañares de Chiara (Huamanga), Aliados de España," pp. 321-353 in Francisco Miró Quesada Cantuarias, Franklin Pease G.Y., \& David Sobrebille A. (eds.), Historia, Problema y Promesa. Lima: Fondo Editorial PUCP.

Espinoza Soriano, Waldemar. 1978b. "Los Mitmas Cañar en el Reino de Yaro (Perú), Siglos XV y XVI,” pp. 345-353 in Francisco Miró Quesada Cantuarias, Franklin Pease G.Y., \& David Sobrebille A. (eds.), Historia, Problema y Promesa. Lima: Fondo Editorial PUCP.

Evans-Pritchard, E. E. 1976[1937]. Witchcraft Oracles and Magic among the Azande (Abridged Ed.). Oxford: Clarendon Press.

Fauria, Carme. 1989. Avance y Limites del Imperio Inca en la Costa Norte. Boletín Americanista (Universitat de Barcelona) 31(39-40): 27-51.

Fernández Alvarado, Julio César. 2008. Cerros, Huacas y Encantos en la Costa Norte Lambayecana del Perú. Perspectivas Latinoamericanas (Nanzan University, Japan) 5: 115.

Fernández Juárez, Gerardo. 1997. Entre la Repugnancia y la Seducción: Ofrendas complejas en los Andes del Sur. Cusco: Centro de Estudios Regionales Andinos "Bartolomé de Las Casas."

Fernández Juárez, Gerardo. 2004. Yatiris y ch ’amakanis del altiplano aymara: Sueños, testimonios y prácticas ceremoniales. Quito: Ediciones Abya-Yala.

Fernández Juárez, Gerardo. 2010. $<<$ Norte contra Sur $>>$. Análisis comparative sobre ofrendas rituales andinas. Revista Española de Antropología Americana (Universidad Complutense de Madrid) 40(1): 239-259.

Foster, George. 1972. The Anatomy of Envy: A Study in Symbolic Behavior. Current Anthropology 13(2): 165-186.

Foster, George. 1976. Disease Etiologies in Non-Western Medical Systems. American Anthropologist 78: 773-782.

Fotiou, Evgenia. 2012. Working with "La Medicina": Elements of Healing in Contemporary Ayahuasca Rituals. Anthropology of Consciousness 23(1): 6-27.

Frazer, James George. 1960[1922]. The Golden Bough: A Study in Magic and Religion (Abridged Ed.). New York: The Macmillan Company.

Fuller, Norma. 2009. Ethical Predicaments for Anthropologists: The Peruvian Case. Development in Practice 19(6): 752-758. 
Gadamer, Hans Georg. 2004[1975]. Truth and Method (2 ${ }^{\text {nd }}$ Ed., trans. Joel Weinsheimer \& Donald G. Marshall). London \& New York: Continuum.

Gelles, Paul H. 2000. Water and Power in Highland Peru: The Cultural Politics of Irrigation and Development. New Brunswick, NJ: Rutgers University Press.

Giese, Claudius. 1991. El rol y significado de las lagunas Huaringas cerca de Huancabamba y el curanderismo en el norte del Peru. Bulletin de l'Institut Français des Études Andines 20(2): 565-587.

Glass-Coffin, Bonnie. 1998. The Gift of Life: Female Spirituality and Healing in Northern Peru. Albuquerque: University of New Mexico Press.

Glass-Coffin, Bonnie. 2010. Shamanism and San Pedro through Time: Some Notes on the Archaeology, History, and Continued Use of an Entheogen in Northern Peru. Anthropology of Consciousness 21(1): 58-82.

Gómez Cumpa, José \& Mónica Amaya Cueva. 1998. “Mórrope, una cultura en el desierto de la costa norte del Perú," pp. 294-345 in Actas del IV Congreso Internacional de Etnohistoria. Lima: Fondo Editorial PUCP.

Gonzales, Michael. 1980. Capitalist Agriculture and Labour Contracting in Northern Peru, 1880-1905. Journal of Latin American Studies 12(2): 291-315.

Good, Byron J. 1994. Medicine, rationality, and experience: An anthropological perspective. Cambridge: Cambridge University Press.

Gose, Peter. 1991. House Rethatching in an Andean Annual Cycle: Practice, Meaning, and Contradiction. American Ethnologist 18(1): 39-66.

Gose, Peter. 1993. Segmentary State Formation and the Ritual Control of Water under the Incas. Comparative Studies in Society and History 35(3): 480-514.

Gose, Peter. 1994. Deathly Waters and Hungry Mountains: Agrarian Ritual and Class Formation in an Andean Town. Toronto: University of Toronto Press.

Gose, Peter. 2000. The State as a Chosen Woman: Brideservice and the Feeding of Tributaries in the Inka Empire. American Anthropologist 102(1): 84-97.

Gose, Peter. 2008. Invaders as Ancestors: On the Intercultural Making and Unmaking of Spanish Colonialism in the Andes. Toronto: University of Toronto Press.

Gow, Peter. 1994. "River People: Shamanism and History in Western Amazonia," pp. 90-113 in Nicholas Thomas \& Caroline Humphrey (eds.), Shamanism, History, and the State. Ann Arbor: University of Michigan Press. 
Greene, Shane. 1998. The Shaman's Needle: Development, Shamanic Agency, and Intermedicality in Aguaruna Lands, Peru. American Ethnologist 25(4): 634-658.

Gudeman, Stephen. 1971. The Compadrazgo as a Reflection of the Natural and Spiritual Person. Proceedings of the Royal Anthropological Institute of Great Britain and Ireland 1971: 45-71.

Guffroy, Jean. 2008. "Cultural Boundaries and Crossings: Ecuador and Peru," pp. 889902 in Helaine Silverman \& William H. Isbell (eds.), The Handbook of South American Archaeology. New York: Springer Science+Business Media.

Hahn, Robert. 1985. Culture-Bound Syndromes Unbound. Social Science \& Medicine 21(2): 165-171.

Harner, Michael. 1972. The Jivaro: People of the Sacred Waterfalls. Garden City, NY: Anchor Books.

Harris, Olivia. 1978. "Complementarity and Conflict: An Andean View of Women and Men," pp. 21-40 in Jean Sybil La Fontaine (ed.), Sex and Age as Principles of Social Differentiation. New York: Academic Press.

Harris, Olivia. 1982. "Labour and produce in an ethnic economy, Northern Potosí, Bolivia," pp. 70-96 in David Lehmann (ed.), Ecology and Exchange in the Andes. Cambridge: Cambridge University Press.

Harris, Olivia. 1995. "Ethnic Identity and Market Relations: Indians and Mestizos in the Andes," pp. 351-390 in Brooke Larson and Olivia Harris (eds.), Ethnicity, Markets, and Migration in the Andes: At the Crossroads of History and Anthropology. Durham \& London: Duke University Press.

Harris, Olivia. 2000[1982]. "The Dead and the Devil," pp. 27-50 in To Make the Earth Bear Fruit: Essays on Fertility, Work and Gender in Highland Bolivia. London: Institute of Latin American Studies, University of London.

Hawley, Katherine. 2012. Trust: A Very Short Introduction. Oxford: Oxford University Press.

Hayashida, Frances. 2006. The Pampa de Chaparrí: Water, Land, and Politics on the North Coast of Peru. Latin American Antiquity 17(3): 243-263.

Hirschkind, Lynn. 1995. History of the Indian Population of Cañar. Colonial Latin American Historical Review 4(3): 311-342.

Hopkins, Diane. 1985. The Peruvian Agrarian Reform: Dissent from Below. Human Organization 44(1): 18-32. 
Huertas Vallejos, Lorenzo. 1987. “Commentarios,” pp. 11-32 in Francisco Alcocer (Lorenzo Huertas Vallejos, ed.), Probanzas de indios y espanoles referentes a las catastroficas lluvias de 1578, en los corregimientos de Trujillo y Sana. Chiclayo: Centro de Estudios Sociales "Solidaridad."

Huertas Vallejos, Lorenzo. 1991. Pertubaciones Etnicas en Piura. Bulletin de l'Institut Français d'Études Andines 20(2): 489-500.

Huertas Vallejos, Lorenzo. 1996. Patrones de Asentamiento Poblacional en Piura (15321850). Bulletin de l'Institut Français d'Études Andines 25(1): 91-124.

Hughes, Charles. 1998. The Glossary of 'Culture-Bound Syndromes' in DSM-IV: A Critique. Transcultural Psychiatry 35(3): 413-421.

Isbell, Billie Jean. 1978. To Defend Ourselves: Ecology and Ritual in an Andean Village. Prospect Heights, IL: Waveland Press.

Joralemon, Donald \& Douglas Sharon. 1993. Sorcery and Shamanism: Curanderos and Clients in Northern Peru. Salt Lake City: University of Utah Press.

Kláren, Peter Flindell. 2000. Peru: Society and Nationhood in the Andes. New York \& Oxford: Oxford University Press.

Kleinman, Arthur. 1973. Medicine's Symbolic Reality. Inquiry 16(1): 206-213.

Kleinman, Arthur. 1988. The Illness Narratives: Suffering. Healing and the Human Condition. New York: Basic Books.

Kleinman, Arthur \& Anne Becker. 1998. "Sociosomatics": The Contributions of Anthropology to Psychosomatic Medicine. Psychosomatic Medicine 60: 389-393.

Koss-Chioino, Joan, Thomas Leatherman, \& Christine Greenway (eds.). 2003. Medical Pluralism in the Andes. London: Routledge.

Laidlaw, James. 2010. "Agency and Responsibility: Perhaps You Can Have Too Much of a Good Thing," pp. 143-164 in Michael Lambek (ed.), Ordinary Ethics: Anthropology, Language, and Action. New York: Fordham University Press.

Lakoff, George \& Mark Johnson. 1980. Metaphors We Live By. Chicago \& London: University of Chicago Press.

Larco, Laura. 2008. Más allá de los encantos: Documentos históricos y etnografía contemporánea sobre exitrpación de idolatrías en Trujillo, siglos XVIII-XX. Lima: Instituto Francés de Estudios Andinos \& Fondo Editorial UNMSM. 
Lazar, Sian. 2008. El Alto, Rebel City: Self and Citizenship in Andean Bolivia. Durham \& New York: Duke University Press.

Leinaweaver, Jessaca. 2008. The Circulation of Children: Kinship, Adoption, and Morality in Andean Peru. Durham \& London: Duke University Press.

Leslie, Charles. 1976. "Introduction," pp. 1-12 in Charles Leslie (ed.), Asian Medical Systems. Berkeley: University of California Press.

Li, Fabiana. 2013. Relating Divergent Worlds: Mines, Aquifers and Sacred Mountains in Peru. Anthropologica 55(2): 399-411.

Llatas Quiroz, Santos \& Mario López Mesones. 2005. Bosques montano-relictos en Kanaris (Lambayeque, Peru). Revista Peruana de Biologia (UNMSM) 12(2): 299-308.

Londoño Sulkin, Carlos. 2012. People of Substance: An Ethnography of Morality in the Colombian Amazon. Toronto: University of Toronto Press.

MacIntyre, Alasdair. 2007[1981]. After Virtue: A Study in Moral Theory (3 ${ }^{\text {rd }}$ Ed.). Notre Dame, IN: University of Notre Dame Press.

Martínez Cereceda, José Luis. 1995. Autoridades en los Andes, los atributos del Señor. Lima: Fondo Editorial PUCP.

Matos Mar, José. 2004. Desborde popular y crises del Estado: Veinte años después. Lima: Fondo Editorial del Congreso del Perú.

Mattingly, Cheryl. 1994. The Concept of Therapeutic 'Emplotment.' Social Science \& Medicine 38(6): 811-822.

Mattingly, Cheryl \& Linda Garro (eds.). 2000. Narrative and the Cultural Construction of Illness and Healing. Berkeley \& Los Angeles: University of California Press.

Mauss, Marcel. 1966[1950]. The Gift: Forms and Functions of Exchange in Archaic Societies (trans. Ian Cunnison). London: Cohen \& West Ltd.

Miller, Solomon. 1967. "Hacienda to Plantation in Northern Peru: The Process of Proletarianization of a Tenant Farmer Society," pp. 133-225 in Julian H. Steward (ed.), Contemporary Change in Traditional Societies. Volume III: Mexican and Peruvian Communities. Urbana \& Chicago: University of Illinois Press.

Millones, Luis. 2002. Las confesiones de don Juan Vazquez. Lima: Instituto Francés de Estudios Andinos \& Fondo Editorial PUCP.

Miño Grijalva, Manuel. 1982. Los cañaris en el Perú. Cultura 5(14): 79-131. 
Moore, Jerry \& Carol Mackey. 2008. “The Chimú Empire,” pp. 783-807 in Helaine Silverman \& William H. Isbell (eds.), The Handbook of South American Archaeology. New York: Springer Science+Business Media.

Murra, John V. 2002[1975]. “En Torno a la Estructura Política de los Inka,” pp. 43-56 in El Mundo Andino: Población, medio ambiente y economía. Lima: Instituto de Estudios Peruanos \& Fondo Editorial PUCP.

Nash, June. 1979. We Eat the Mines and the Mines Eat Us: Dependency and Exploitation in Bolivian Tin Mines. New York: Columbia University Press.

Neiman, Susan. 2002. Evil in Modern Thought: An alternative history of philosophy. Princeton \& Oxford: Princeton University Press.

Nichter, Mark. 2010. Idioms of Distress Revisited. Culture, Medicine, Psychiatry 34: $401-416$.

Oberem, Udo. 1974. Los Cañaris y la conquista española de la Sierra ecuatoriana, otro capítulo de las relaciones interétnicas en el siglo XVI. Journal de la Sociétè des Américanistes 63: 263-274.

Oberem, Udo \& Roswith Hartmann. 1979. Indios Cañaris de la Sierra Sur del Ecuador en el Cuzco del siglo XVI. Revista de la Universidad Complutense 28(117): 373-390.

Paerregaard, Karsten. 1997. Linking Separate Worlds: Urban Migrants and Rural Lives in Peru. Oxford \& New York: Berg.

Peralta Ruiz, Víctor. 1998. "Caminantes del Desierto: Arrieros y Comerciantes Indígenas en Lambayeque, Siglo XVIII," pp. 143-167 in Scarlett O'Phelan Godoy \& Yves SaintGeours (eds.), El Norte en la Historia Regional, Siglos XVIII-XIX. Lima: Instituto Francés de Estudios Andinos.

Platt, Tristan. 1983. Conciencia andina y conciencia proletaria: Qhuyaruna y ayllu en el norte de Potosi. HISLA: Revista latinoamericana de historia económica y social 2: 47-73.

Platt, Tristan. 1986. "Mirrors and maize: The concept of yanantin among the Macha of Bolivia," pp. 228-259 in John V. Murra, Nathan Wachtel, \& Jacques Revel (eds.), Anthropological History of Andean Polities. Cambridge: Cambridge University Press.

Polia, Mario. 1989a. Las lagunas de los encantos: medicina tradicional andina del Perú septentrional $\left(2^{\text {nd }}\right.$ Ed.). Piura: CEPESER.

Polia, Mario. 1989b. "Contagio" y "pérdida de la sombra" en la teoría y práctica del curanderismo andino del Perú septrentrional: provincias de Ayabaca y Huancabamba. Anthropologica (PUCP) 7(7): 195-231. 
Polia, Mario. 1994a. "El curandero, sacerdote tradicional de los encantos," pp. 284-330 in Luis Millones and Moises Lemlij (eds.), En el Nombre del Señor: Shamanes, demonios y curanderos del Norte del Perú. Lima: BPP-SIDEA.

Polia, Mario. 1994b. Cuando Dios lo permite: encantos y arte curanderil. Lima: Prometeo.

Polia, Mario. 1996. "Despierta, remedio, cuenta”: advinos y médicos del Ande (2 volumes). Lima: Fondo Editorial PUCP.

Polia, Mario. 2001. “Adivinos y médicos del Ande: un reto para el tercer milenio," pp. 65-90 in Max Hernández et al. (eds.), El Perú en los albores del siglo XXI: ciclo de conferencias. Lima: Fondo Editorial del Congreso del Perú.

Polia, Mario. 2005. Glosario del curanderismo andindo en el Departamento de Piura (Perú). Lima: Fondo Editorial UNMSM.

Polia, Mario 2006. "Andean Cosmology and Cosmography in the North-Peruvian shamanic Mesa," pp. 31-48 in Douglas Sharon (ed.), Mesas and Cosmologies in the Central Andes. San Diego: San Diego Museum Papers No. 44.

Polia, Mario \& Fabiola Chávez Hualpa. 1994. "El curandero, sacerdote traditional de los encantos,” pp. 284-330 in Luis Millones \& Moises Lemlij (eds.), En el Nombre del Señor: Shamanes, demonios y curanderos del norte del Perú. Lima: Biblioteca Peruana de Psicoanalysis.

Poole, Deborah. 1988. Landscapes of Power in a Cattle-Rustling Culture of Southern Andean Peru. Dialectical Anthropology 12: 367-398.

Pozorski, Shelia \& Thomas Pozorski. 2008. "Early Cultural Complexity on the Coast of Peru," pp. 607-631 in Helaine Silverman \& William H. Isbell (eds.), The Handbook of South American Archaeology. New York: Springer Science+Business Media.

Quesada Castillo, Felix. 1976. Diccionario Quechua: Cajamarca-Cañaris. Lima: Ministerio de Educación.

Ramírez, Susan. 1987. The "Dueño de Indios": Thoughts on the Consequences of the Shifting Bases of Power of the "Curaca de los Viejos Antiguos" under the Spanish in Sixteenth-Century Peru. Hispanic American Historical Review 67(4): 575-610.

Rasnake, Roger Neil. 1988. Domination and Cultural Resistance: Authority and Power Among an Andean People. Durham: Duke University Press.

Reyes Flores, Alejandro. 1999. Hacendados y Comerciantes: Piura - Chachapoyas Moyobamba - Lamas - Maynas (1770-1820). Lima: Fondo Editorial UNMSM. 
Rostworowski de Diez Canseco, María. 1999[1988]. Historia del Tahuantinsuyu $\left(2^{\text {nd }}\right.$ Ed.). Lima: Instituto de Estudios Peruanos.

Rostworowski de Diez Canseco, María. 2001[1953]. Obras Completas de María Rostworowski I: Pachacutec Inca Yupanqui. Lima: Instituto de Estudios Peruanos.

Salazar-Soler, Carmen. 2006. Supay Muqui, dios del socavón: Vida y mentalidades mineras. Lima: Fondo Editorial del Congreso del Perú.

Santos-Grandero, Fernando. 1991. The Power of Love: The Moral Use of Knowledge Amongst the Amuesha of Central Peru. London \& Atlantic Highlands, NJ: Athlone Press.

Santos-Grandero, Fernando. 2002. Boundaries are Made to be Crossed: The Magic and Politics of the Long-lasting Amazon/Andes Divide. Identities: Global Studies in Culture and Power 9: 545-569.

Sax, Marieka. 2011. An Ethnography of Feeding, Perceptionm and Place in the Peruvian Andes (Where Hungry Spirits Bring Illness and Wellbeing). Lewiston, NY: Edwin Mellen Press.

Seligmann, Linda. 1993. The Burden of Visions amidst Reform: Peasant Relations to Law in the Peruvian Andes. American Ethnologist 20(1): 25-51.

Seligmann, Linda. 2004. Peruvian Street Lives: Culture, Power, and Economy among Market Women of Cuzco. Urbana \& Chicago: University of Illinois Press.

Sevilla Exebio, Julio César. 1998. "La etnia de los penachíes," pp. 478-502 in Actas del IV Congreso Internacional de Etnohistoria. Lima: Fondo Editorial PUCP.

Sevilla Exebio, Julio César. 2005. La fiesta de la Cruz de Penachí y la Danza rojo y blanco. UMBRAL: Revista Semestral de Educación, Cultura y Sociedad (Universidad Nacional Pedro Ruiz Gallo, Lambayeque, Peru) 5(9-10): 38-51.

Sharon, Douglas. 1978. Wizard of the Four Winds: A Shaman's Story. New York: Free Press.

Silverman, Helaine \& William H. Isbell (eds.). 2008. The Handbook of South American Archaeology. New York: Springer Science+Business Media.

Simons, Ronald \& Charles Hughes (eds.). 1985. The Culture-Bound Syndromes: Folk Illnesses of Psychiatric and Anthropological Interest. Dordrecht: D. Reidel.

Steigenga, Timothy \& Edward Cleary. 2007. "Understanding Conversion in the Americas," pp. 3-32 in Timothy Steigenga \& Edward Cleary (eds.), Conversion of a Continent: Contemporary Religious Change in Latin America. New Brunswick, NJ: Rutgers University Press. 
Tambiah, Stanley Jeyaraja. 1985[1979]. "A Performative Approach to Ritual," pp. 123166 in Culture, Thought, and Social Action: An Anthropological Perspective. Cambridge \& London: Harvard University Press.

Tambiah, Stanley Jeyaraja. 1990. Magic, science, religion, and the scope of rationality. Cambridge: Cambridge University Press.

Taylor, Gerald. 1982. Breve Presentación de la Morfología del Quechua de Ferreñafe. Lexis 6(2): 243-270.

Taylor, Gerald. 1996. El Quechua de Ferreñafe: Fonología, morfología, léxico. Cajamarca, Peru: Acku Quinde.

Taylor, Gerald. 2008. L'ogresse dans les Andes et en Amazonie. Bulletin de l'Institut Français d'Études Andines 37(2): 293-328.

Turner, Victor. 1969. The Ritual Process: Structure and Anti-Structure. Ithaca, NY: Cornell University Press.

Urton, Gary. 1992. "Communalism and Differentiation in an Andean Community," pp. 231-266 in Robert Dover, Katherine Seibold, \& John McDowell (eds.), Andean Cosmologies Through Time: Persistence and Emergence. Bloomington: Indiana University Press.

Viveiros de Castro, Eduardo. 1998. Cosmological Deixis and Amerindian Perspectivism. The Journal of the Royal Anthropological Institute 4(3): 469-488.

Vreeland, James M. Jr. 1991. "Pilgrim's Progress: The Emergence of Secular Authority in a Traditional Andean Pilgrimage," pp. 229-256 in N. Ross Crumrine \& Alan Morinis (eds.), Pilgrimage in Latin America. Westport CT: Greenwood Press.

Vreeland, James M. Jr. 1993. "Danzas tradicionales de la sierra de Lambayeque," pp. 179-217 in Raúl Romero (ed.), Música, danzas y máscaras en los Andes. Lima: Fondo Editorial PUCP.

Waldram, James. 1999. The Efficacy of Traditional Medicine: Current Theoretical and Methodological Issues. Medical Anthropology Quarterly 14(4): 603-625.

Weigend, Maximilian. 2002. Observations on the Biogeography of the AmotapeHuancabamba Zone in Northern Peru. Botanical Review 68(1): 38-54.

Weigend, Maximilian. 2004. Additional observations on the biogeography of the Amotape-Huancabamba zone in Northern Peru: Defining the South-Eastern limits. Revista Peruana de Biología (UNMSM) 11(2): 127-134. 
Weigend, Maximilian, Eric Rodriguez, \& Cesar Arana. 2005. The relict forests of Northwest Peru and Southwest Ecuador. Revista Peruana de Biología (UNMSM) 12(2): 185-194.

Weismantel, Mary. 1988. Food, Gender, and Poverty in the Ecuadorian Andes.

Philadelphia: University of Pennsylvania Press.

Weismantel, Mary. 2001. Cholas and Pishtacos: Stories of Race and Sex in the Andes. Chicago: University of Chicago Press.

Whitten, Norman E. Jr. 1976. Sacha Runa: Ethnicity and Adaptation of Ecuadorian Jungle Quichua. Urbana \& Chicago: University of Illinois Press.

Young, Allan. 1982. The Anthropologies of Illness and Sickness. Annual Review of Anthropology 11: 257-285.

\section{Unpublished manuscripts}

Castañeda Murga, Juan. n.d. "La Guerra por el Agua en Pacora. Siglos XVI-XIX."

Unpublished manuscript, courtesy of the author.

Castañeda Murga, Juan \& Carmen Espinoza Córdova. 2011. "Templos Virreinales de los Valles de Lambayeque." Unpublished book manuscript, courtesty of Juan Castañeda Murga.

\section{Newspaper articles and online news sources}

BBC News. 05/06/09. "Deadly clashes in Peru's Amazon." n.a. Retrieved June 30, 2014. http://news.bbc.co.uk/2/hi/americas/8086595.stm.

BBC News. 10/06/09. "Peru polarised after deadly clashes." Dan Collyns. Retrieved June 30, 2014. http://news.bbc.co.uk/2/hi/americas/8093729.stm.

BBC News. 19/06/09. "Peru Indians hail 'historic' day.” n.a. Retrieved June 20, 2014. http://news.bbc.co.uk/2/hi/americas/8109021.stm.

$B B C$ News. 06/09/11. "Peru's president approves indigenous consultation law." n.a. Retrieved June 30, 2014. http://www.bbc.com/news/world-latin-america-14812506.

BBC News. 24/11/11. "Peru protests at huge Conga gold mine in Cajamarca." n.a. Retrieved June 30, 2014. http://www.bbc.com/news/world-latin-america-15884119.

BBC News. 30/11/11. "Protests in Peru halt Newmont gold mine project." n.a. Retrieved June 30, 2014. http://www.bbc.co.uk/news/world-latin-america-15956429. 
BBC News. 05/12/11. "Peru declares state of emergency over disputed mine." n.a. Retrieved June 30, 2014. http://www.bbc.co.uk/news/world-latin-america-16026619.

El Comercio. 09/11/11. "Cajamarca está paralizada en contra de minera." n.a. Retrieved June 29, 2014. http://elcomercio.pe/peru/lima/cajamarca-esta-paralizada-contra-mineranoticia-1330887.

El Comercio. 01/10/12. "Lambayeque: Población votó en contra del proyecto minero Cañariaco." n.a. Retrieved June 29, 2014. http://elcomercio.pe/peru/lima/lambayequepoblacion-voto-contra-proyecto-minero-canariaco-noticia-1477037.

El Comercio. 11/10/12. "Ministerio de Energía y Minas desconoce consulta popular contra Cañariaco." n.a. Retrieved June 29, 2014.

http://elcomercio.pe/peru/lima/ministerio-energia-minas-desconoce-consulta-popularcontra-canariaco-noticia-1481186.

El Comercio. 04/01/13. "Pese a protestas reanudan perforaciones exploratorias en proyecto Cañariaco." Wilfedo Sandoval. Retrieved June 29, 2014.

http://elcomercio.pe/peru/lima/pese-protestas-reanudan-perforaciones-exploratoriasproyecto-canariaco_1-noticia-1518235.

El Comercio. 21/01/13a. "Lambayeque: comuneros de Cañaris acatan paro indefinido contra minera." n.a. Retrieved June 29, 2014. http://elcomercio.pe/peru/lima/lambayequecomuneros-canaris-acatan-paro-indefinido-contra-minera-noticia-1526066.

El Comercio. 21/01/13b. "Protesta en Cañaris: unos 300 policías buscarán poner orden." n.a. Retrieved June 29, 2014. http://elcomercio.pe/peru/lima/protesta-canaris-300policias-buscaran-poner-orden-noticia-1526193.

El Comercio. 22/01/13. "Protestas en Cañaris: policías resuguardan campamento minero." n.a. Retrieved June 29, 2014. http://elcomercio.pe/peru/lima/protestas-canarispolicias-resguardan-campamento-minero-noticia-1526524.

El Comercio. 25/01/13. "Protestas en Cañaris: manifestantes y policía se enfrentaron en desalojo de vía." n.a. Retrieved June 29, 2014. http://elcomercio.pe/peru/lima/protestascanaris-policia-manifestantes-se-enfrentaron-desalojo-via-noticia-1527978.

El Comercio. 28/01/13a. " 'No aceptaremos salida de Candente Copper para iniciar diálogo en Cañaris.' " n.a. Retrieved June 29, 2014. http://elcomercio.pe/politica/gobierno/no-aceptaremos-salida-candente-copper-iniciardialogo-canaris-noticia-1529434.

El Comercio. 28/01/13b. "Protestas en Cañaris: la Policía negó muerte de manifestante durante enfrentamientos." n.a. Retrieved June 29, 2014. http://elcomercio.pe/peru/lima/protestas-canaris-policia-nego-muerte-manifestantedurante-enfrentamientos-noticia-1529605. 
El Comercio. 02/02/13. "Cañaris: ministerios de Cultura y Ambiente se sumaron a mesa de diálogo." n.a. Retrieved June 29, 2014. http://elcomercio.pe/peru/lima/canarisministerios-cultura-ambiente-se-sumaron-mesa-dialogo-noticia-1531661.

El Comercio. 03/02/13. "Cañaris: invertirán S/.100 millones para obras de electrificación y riego." n.a. Retrieved June 29, 2014. http://elcomercio.pe/economia/peru/canarisinvertiran100-millones-electrificacion-riego-noticia-1532121.

El Comercio. 14/02/13. “Sombras nada más.” Editorial. Retrieved June 29, 2014. http://elcomercio.pe/politica/opinion/editorial-sombras-nada-mas-noticia-1536780.

El Comercio. 03/04/13. "DESCARGA: esta es la guía para aplicar la consulta previa." n.a. Retrieved June 29, 2014..http://elcomercio.pe/peru/lima/descarga-esta-guia-aplicarconsulta-previa-noticia-1558643.

El Comercio. 06/04/13. "Cañaris: cuarta mesa de diálogo no abordó conflicto por proyecto Cañariaco." n.a. Retrieved June 29, 2014.

http://elcomercio.pe/peru/lima/canaris-cuarta-mesa-dialogo-no-abordo-conflictoproyecto-canariaco-noticia-1560127.

El Comercio. 05/05/13. "Gobierno sabe que 14 proyectos mineros requieren consulta." Nelly Luna Amancio. Retrieved June 29, 2014. http://elcomercio.pe/peru/lima/mapagobierno-sabe-que-14-proyectos-mineros-requieren-consulta-noticia-1572596.

El Comercio. 11/05/13. "Descubren yacimientos significativos de oro y plata en Cañariaco Sur.” Wilfredo Sandoval. Retrieved June 29, 2014.

http:/elcomercio.pe/peru/lima/descubren-yacimientos-significativos-oro-plata-canariacosur-noticia-1575173.

El Comercio. 17/05/13. "Minera Candente Copper suspendió sus actividades en proyecto Cañariaco.” n.a. Retrieved June 29, 2014. http://elcomercio.pe/economia/peru/mineracandente-copper-suspendio-sus-actividades-proyecto-canariaco-noticia-1577706.

El Comercio. 18/05/13. "Suspensión de proyecto minero podría mejorar el diálogo en Cañaris." n.a. Retrieved June 29, 2014. http://elcomercio.pe/peru/lima/suspensionproyecto-minero-podria-mejorar-dialogo-canaris_1-noticia-1578021.

El Comercio. 22/05/13. "Ollanta Humala: 'Ley de la consulta previa no es un obstáculo a las inversiones.' " n.a. Retrieved June 29, 2014.

http://elcomercio.pe/politica/gobierno/ollanta-humala-ley-consulta-previa-no-obstaculoinversiones-noticia-1579783.

El Comercio. 29/05/13. "Comuneros de Cañaris demandaron al Estado ante la CIDH." Wilfredo Sandoval. Retrieved June 29, 2014. http://elcomercio.pe/peru/lima/comuneroscanaris-demandaron-al-estado-ante-cidh-noticia-1582566. 
El Comercio. 26/10/13. "Ministerio de Cultura publicó la Base de Datos de Pueblos Indígenas.” n.a. Retrieved June 29, 2014. http://elcomercio.pe/peru/lima/ministeriocultura-publico-base-datos-pueblos-indigenas-noticia-1650056.

El Comercio. 22/02/14a. "Cañaris: Cronología de un conflicto que sigue sin resolverse." n.a. Retrieved June 29, 2014. http://elcomercio.pe/peru/lambayeque/canaris-cronologiaconflicto-que-sigue-sin-resolverse-noticia-1711496.

El Comercio. 22/02/14b. "Reinician protesta contra proyecto minero Cañariaco." n.a. Retrieved June 29, 2014. http://elcomercio.pe/peru/lambayeque/reinician-protestascontra-proyecto-minero-canariaco-noticia-1711476.

El Comercio. 23/02/14. "Comuneros reinician protestas contra Cañariaco.” Wilfredo Sandoval. Retrieved June 29, 2014. http://elcomercio.pe/peru/lambayeque/comunerosreinician-protestas-contra-canariaco-noticia-1711567.

El Comercio. 21/04/14. "Inconsulta previa, por Irma Montes Patiño." Irma Montes Patiño. Retrieved June 29, 2014. http:/elcomercio.pe/opinion/columnistas/inconsultaprevia-irma-montes-patino-noticia-1724018.

El Comercio. 13/05/14. “'Baguazo': la 'Curva del diablo’ ardió hace casi 5 año.” n.a. Retrieved June 29, 2014. http://elcomercio.pe/peru/amazonas/baguazo-curva-diabloardio-hace-casi-5-anos-noticia-1729279.

The Economist. 02/02/13. "Peru's roaring economy: Hold on tight." n.a. Retrieved July 1, 2014. http://www.economist.com/news/americas/21571162-biggest-threats-latinamericas-economic-star-are-overconfidence-and-complacency-hold.

The New York Times. 05/06/09. "Fatal Clashes Erupt in Peru at Roadblock." Simon Romero. Retrieved June 30, 2014. http://www.nytimes.com/2009/06/06/world/americas/06peru.html?module=Search\&mab Reward $=$ relbias $\% 3 \mathrm{Aw} \% 2 \mathrm{C}[\% 22 \mathrm{RI} \% 3 \mathrm{~A} 6 \% 22 \% 2 \mathrm{C} \% 22 \mathrm{RI} \% 3 \mathrm{~A} 14 \% 22]$.

The New York Times. 14/06/10. "Tangled Strands in Fight Over Peru Gold Mine.” n.a. Retrieved June 30, 2014.

http://www.nytimes.com/2005/10/25/international/americas/25GOLD.html?pagewanted= all $\&$ module $=$ Search $\&$ mabReward $=$ relbias $\% 3 \mathrm{Aw} \% 2 \mathrm{C}[\% 22 \mathrm{RI} \% 3 \mathrm{~A} 6 \% 22 \% 2 \mathrm{C} \% 22 \mathrm{RI} \% 3$ A14\%22].

The New York Times. 11/12/11. "Peru Official Steps Down Amid Fight Over a Mine." Simon Romero. Retrieved June 30, 2014. http://www.nytimes.com/2011/12/11/world/americas/top-peruvian-official-quits-amidprotest-over-mining-

project.html? module $=$ Search $\&$ mabReward $=$ relbias $\% 3 \mathrm{Aw} \% 2 \mathrm{C}[\% 22 \mathrm{RI} \% 3 \mathrm{~A} 6 \% 22 \% 2 \mathrm{C} \%$ 22RI\%3A14\%22]. 
The New York Times. 19/08/13. “As a Boom Slows, Peru Grows Uneasy.” William Neuman. Retrieved June 30, 2014.

http://www.nytimes.com/2013/08/20/world/americas/as-a-boom-slows-peru-growsuneasy.html?pagewanted=all.

Rivera Andía, Juan Javier \& Marieka Sax. 2011. "La Cruz de Yanahuanca: La fiesta en San Mateo de Penachí, Salas," pp. 2-4 in Variedades (supplementary insert to $E l$ Peruano), 14 March 2011.

\section{Online documents}

Candente Copper Corp. 2011. "Cañariaco Norte Copper Project Pre-Feasibility Study Progress Report." Submitted to Candente Copper Corp., 11 March 2011. Project N ${ }^{\circ}$ 165270. Retrieved June 16, 2014. http://www.candentecopper.com/s/PeruProjects_Canariaco.asp.

Deininger, Klaus, Harris Selod, and Anthony Burns. 2012. "The Land Governance Assessment Framework: Identifying and Monitoring Good Practice in the Land Sector." Washington, DC: World Bank Publications. Retrieved July 1, 2014. https://openknowledge.worldbank.org/bitstream/handle/10986/2376/657430PUB0EPI106 5724B09780821387580.pdf? sequence=1.

Instituo Nacional de Estadística e Informática (INEI). 2007. “Censos Nacionales 2007 XI de Población y VI de Vivienda." Sistema de consulta de principales indicadores demográficos, sociales y económicos: Mapas. 140202: Departamento Lambayeque, Provincia Ferreñafe, Distrito Cañaris. Retrieved June 28, 2014. http://censos.inei.gob.pe/Censos2007/IDSE/

Instituo Nacional de Estadística e Informática (INEI). 2009. "Peru migraciones internas 1993-2007." Retrieved June 28, 2014.

http://www.inei.gob.pe/media/MenuRecursivo/publicaciones_digitales/Est/Lib0801/libro. pdf

Viceministerio de Interculturalidad. 2013. "Guía Metodológica. Consulta a los Pueblos Indígenas." Ley $\mathrm{N}^{\circ} 29785$, Ley del Derecho a la Consulta Previa a los Pueblos Indígenas u Originarios, reconocido en el Convenio $\mathrm{N}^{\circ} 169$ de la Organización Internacional del Trabajo (OIT), Ley $\mathrm{N}^{\circ} 29785$ Reglamento de la Ley $\mathrm{N}^{\circ} 29785$, Ley del Derecho a la Consulta Previa, Decreto Supremo No 001-2012-MC. Ministerio de Cultura, Perú. Retrieved June 29, 2014 from El Comercio link. http://elcomercio.pe/peru/lima/descargaesta-guia-aplicar-consulta-previa-noticia-1558643. 


\section{Other online sources}

Latin Lawyer. 24/04/14. "Peru. Mining 2014 Reference." Sandra Orihuela. Retrieved June 30, 2014. http://latinlawyer.com/reference/topics/46/jurisdictions/19/peru/.

Municipalidad Distrital de Kañaris. n.d. "Datos del Distrito.” n.a. Retrieved June 28, 2014. http://www.munikanaris.gob.pe/DatosDistrito.php.

Peru Support Group. 31/08/11. "Peru News Summary: August 2011. Congress approves consultation law." n.a. Retrieved June 30, 2014. http://www.perusupportgroup.org.uk/news-article-519.html\#519.

Peru Support Group. 09/09/11. "European NGOs Congratulate Government on Prior Consultation Law." n.a. Retrieved June 30, 2014.

http://www.perusupportgroup.org.uk/news-article-521.html.

Peru Support Group. 04/02/13. "Canaris: clashes as rejected mine considered." n.a. Retrieved June 30, 2014. http://www.perusupportgroup.org.uk/news-article-607.html.

Peru Support Group. 18/06/13. "Community seeks consultation right via international system.” n.a. Retrieved June 30, 2014. http://www.perusupportgroup.org.uk/news-article644.html.

Peru Support Group. 12/11/13. "Controversy greets indigenous consultation database." n.a. Retrieved June 30, 2014. http://www.perusupportgroup.org.uk/news-article-686.html. 